\title{
Ownership Trends in Corporate India $2001-2011$ \\ Evidence and Implications
}

\author{
Bala N. Balasubramanian \\ Anand Ramaswamy
}

W.P. No. 2013-10-03

October 2013

The main objective of the working paper series of the IIMA is to help faculty members, research staff and doctoral students to speedily share their research findings with professional colleagues and test their research findings at the pre-publication stage. IIMA is committed to maintain academic freedom. The opinion(s), view(s) and conclusion(s) expressed in the working paper are those of the authors and not that of IIMA.

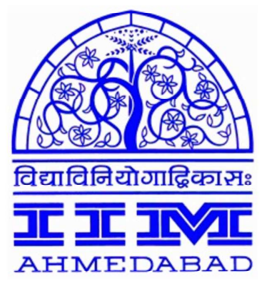

INDIAN INSTITUTE OF MANAGEMENT

AHMEDABAD-380 015

INDIA 


\title{
Ownership Trends in Corporate India 2001 - 2011 \\ Evidence and Implications
}

\begin{abstract}
The first decade of the new millennium saw dramatic changes in the ownership patterns in major listed corporations in India. Two developments were striking: promoters especially in the domestic private sector bolstered up their holdings to assure continued entrenchment; and institutional investors significantly increased their holdings especially in the private sector management controlled companies segment. In both cases, these increases were achieved at the cost of retail non-institutional shareholders whose holdings correspondingly recorded a steep fall. This paper documents this evidence, seeks to identify their underlying rationale and assess their implications for corporate equity investment and governance in the country.
\end{abstract}

(C) 2013 Authors

\section{Bala N Balasubramanian,}

Adjunct Faculty, Indian Institute of Management Ahmedabad

Email: bala4391@gmail.com

\section{Anand Ramaswamy}

Research Associate, Indian Institute of Management Bangalore anandvijayasankaran@gmail.com 


\section{Contents}

I

Corporations and their Evolution in India ............................................................. 5

Ownership Trends around the World ...................................................................... 7

Ownership Patterns in India ..................................................................................... 7

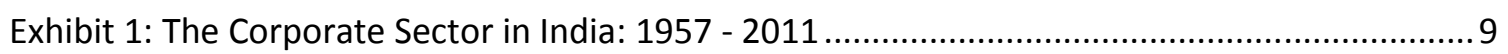

Concentrated vs. Dispersed Ownership.................................................................. 9

Voting Rights - Democratic vs. Plutocratic .............................................................. 9

Inter-Corporate Ownership -Pyramids \& Groups .............................................. 10

Board Interlocks ................................................................................................................. 11

II ……

Ownership of Indian Corporations...................................................................... 12

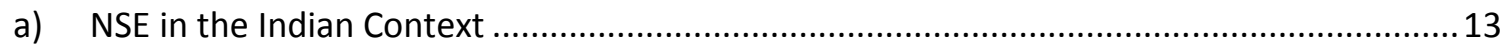

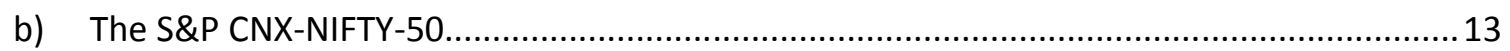

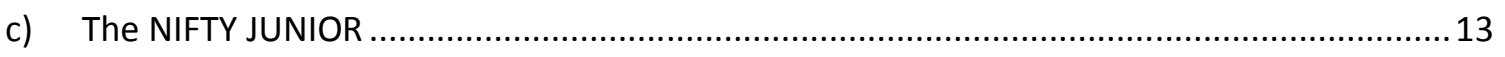

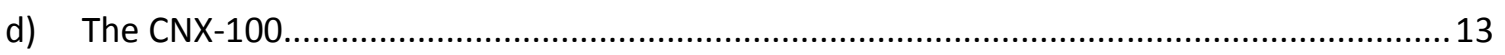

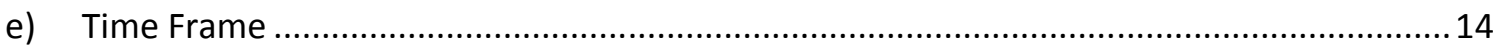

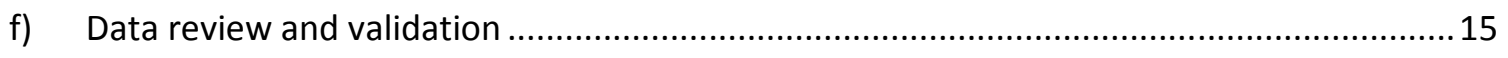

Classification of Companies ....................................................................................... 16

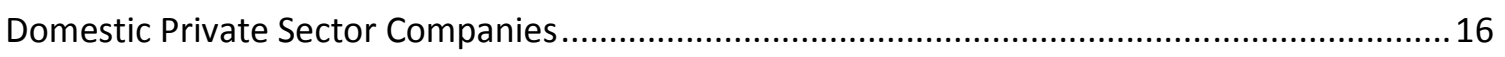

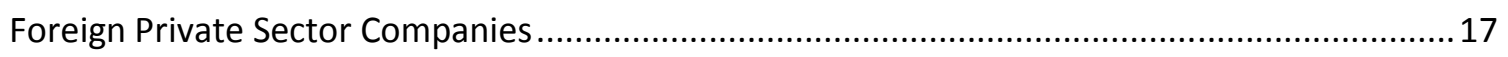

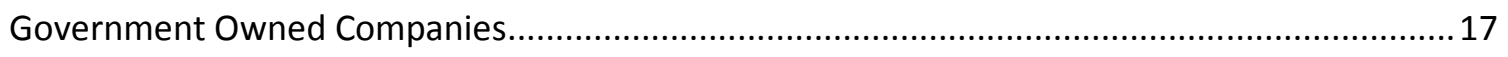

Management Controlled Companies ................................................................................. 17

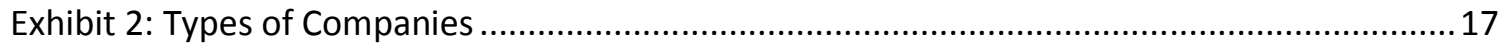

Classification of Shareholders ....................................................................................... 18

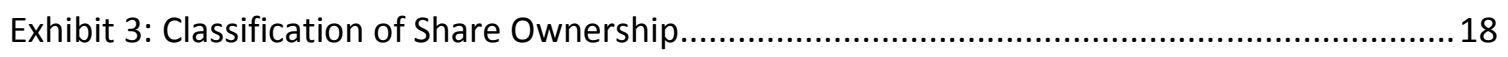

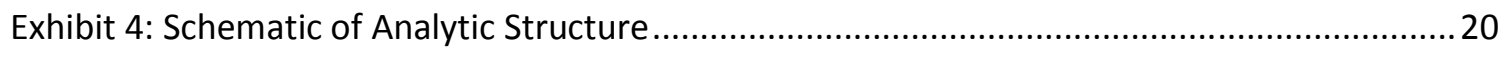

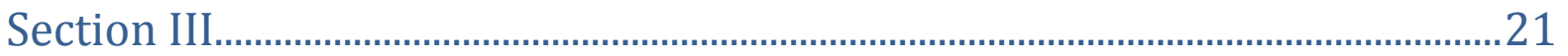

Analysis and Observations..................................................................................... 21 
Set A: Index Companies at Each Year-end: ........................................................... 21

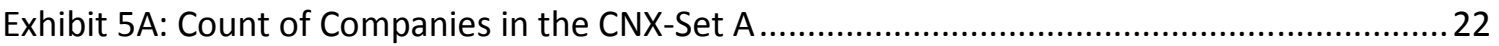

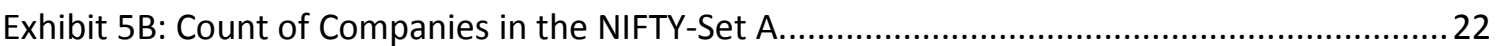

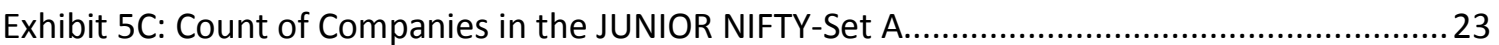

Exhibit 6A: Frequency Distribution of Promoter/Government Companies in CNX-100.............26

Exhibit 6B: Frequency Distribution of Promoter/Government Companies in NIFTY.................27

Exhibit 6C: Frequency Distribution of Promoter/Government Companies in NIFTY JUNIOR......27

Set B: Index Companies in 2011 over Ten Preceding Years ............................................. 28

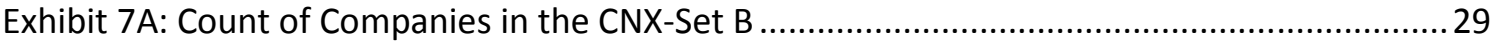

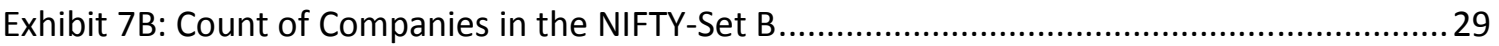

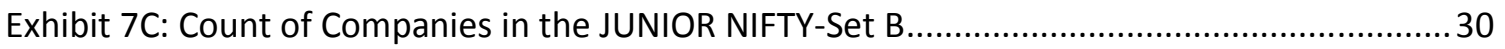

Exhibit 8A: Frequency Distribution of Promoter/Government Companies in CNX-100..............32

Exhibit 8B: Frequency Distribution of Promoter/Government Companies in NIFTY...................32

Exhibit 8C: Frequency Distribution of Promoter/Government Companies in NIFTY JUNIOR.......33

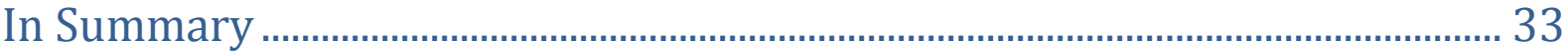

Implications for Governance .............................................................................. 34

Exhibit 9: Summary Statistics- Index Composition and Market Capitalisation...........................37

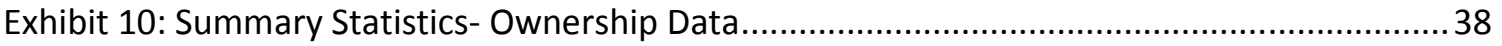

References 


\section{Ownership Trends in Corporate India 2001 - 2011 \\ Evidence and Implications}

The corporation as a preferred business format for large (and/or) risky ventures has come to stay as a global phenomenon. Societies around the world (represented by their governments) have facilitated and encouraged their growth as instruments of their own wellbeing and competitive advantage among the comity of nations. As vehicles of private enterprise and personal enrichment, corporations can be at cross purposes with societal expectations of how they are to be run, especially in terms of their positive contributions and negative costs of operation. Ownership and control of corporations under the watchful stewardship and surveillance of their boards have a significant influence in shaping corporate behavior and the equitable management of relationships between and among themselves, the society and communities they serve, and the governments of the countries they operate in.

This paper tracks the movements in corporate ownership in India among its top companies in the first decade of the new millennium and moving forward in to the second. It offers a fascinating kaleidoscope of the changing political and regulatory environment driving ownership patterns in sympathy. The paper is organized as follows: section I provides a brief overview of the development of the corporate format of business organizations globally and especially in India; section II describes the sample and its categorization for analysis, methodology and other background information; and section III sets out the findings, interpretation and conclusions. An Annexure of a comprehensive set of statistical exhibits completes the presentation. 


\section{Corporations and their Evolution in India}

Looking back at the evolutionary history of the corporation as known today, one could discern at least three major defining developments. First was the artificial creation of the corporate entity by a legal sleight, followed by the introduction of limited liability, the acceptance of the corporations' right to invest in and hold stock of another corporation, and finally, the shift from democratic to plutocratic voting rights, moving away from one vote per shareholder to one vote per share and thence to even more skewed differential voting rights.

The second was the emergence of the publicly traded corporation representing a paradigm shift in the way business could be scaled up, where owners of a slice of the corporation (represented by the proportion of shares held) neither had claims to the property (net of liabilities) of their company in kind nor the obligation to be permanently wedded to their shareholdings; they could exit by selling their shares or otherwise disposing them off. As Berle and Means (1932, pp. vii-viii) pointed out some eighty years ago, this development transformed significant proportions of the nation's industrial wealth from essentially individual ownership to corporate ownership, in the process changing the lives of property owners and workers, and in fact even the very concepts of property ownership, ushering in virtually a new format of economic organization.

The third defining element in modern corporate governance was the development of the corporate board itself and its role, responsibility and accountability. Undoubtedly, the board is 'elected' by the shareholders (usually by the dominant shareholders or the executive management depending upon the country's ownership patterns) but once so elected the board is virtually its own arbiter in all matters relating to the company. With the demise ${ }^{1}$ of the active, small time entrepreneurial investor-manager and the ascent of the generally

\footnotetext{
${ }^{1}$ Especially in the context of large scale high-risk enterprises; the small and medium scale entrepreneurs continue to thrive elsewhere and constitute a very substantial part of the Indian economy and business
} 
passive absentee ${ }^{2}$ shareholders in the corporate format of business, executive management took over that function subject to the supervision and oversight of the board. Influential legal scholars like Adolf Berle (1931), Merrick Dodd (1932), Lynn Stout (2002, 2012), Lucian Bebchuk (2005, 2006), Stephen Bainbridge (2002, 2005) and Leo Strine, Jr. (2006), among

others, have been debating the pros and cons of greater shareholder involvement in corporate decision making but as of now the absentee shareholders in many jurisdictions have to be satisfied largely with their (theoretical) right of having a say in the election of the directors to the board and thereafter hoping their interests would be fairly protected. Indian shareholders however are comparatively better off than most of their western compatriots in that they have superior rights in law especially with the legislative and regulatory reforms in $2013^{3}$, albeit often neutralized by dominant shareholders' voting power and the general indifference of institutional shareholders.

Shareholder primacy is impacted variously by the ownership structures of the corporation. Dominant ownership (which includes but not necessarily requires majority holdings) which is widely prevalent around the world including India, with the exception of the United States and United Kingdom, can be a double-edged sword: owners with long term interests in the company can offer stability and proprietary oversight to ensure efficiencies but can also potentially inflict costs of extraction of private benefits of control to the exclusion of other shareholders. The managerial model of the corporation prevalent in the US and UK, with dispersed ownership, while avoiding the demerits of the dominant ownership can and often does exhibit agency costs arising from fundamental non-congruence between shareholder and manager interests. These are generally manifested in the form of unconscionable executive compensation, bonuses and severance terms, besides use of corporate funds and resources for personal aggrandisement, self-seeking philanthropy, overly risky business practices, leveraged buyouts and manipulative gains on stock options through creative earnings management, self-dealings, and so on. A desirable model that would incorporate

\footnotetext{
2 A term we use to denote all shareholders not associated with operational control of the corporation, in preference to the general usage of 'minority ' shareholders since often this category happens to be the majority in most corporations

${ }^{3} \mathrm{~A}$ review of the improvements and their impact on good governance is available in Balasubramanian (2013)
} 
the positives and eschew the negatives of either form of ownership is a theoretical possibility but in reality, barring miniscule exceptions, it is hard to come by.

Within the confines of the modern day corporation, both accountability and responsibility are heavily impacted by ownership. Ownership structure can also mediate firm strategy and behavior (Wright, et al, 1996) and can influence boardroom dynamics and stakeholder management (Goodstein and Boecker, 1991), executive compensation (David, Kochhar and Levitas, 1998; Balasubramanian, et al, 2013)), and R\&D investment (Baysinger, Kosnik and Turk, 1991). An understanding of ownership patterns and trends can thus lead us to more nuanced understanding of organizational behaviour and its predictability.

\section{Ownership Trends around the World}

Academic research on corporate ownership has often been dominated by studies focused on the United States and the United Kingdom both with predominantly dispersed ownership structures. Studies by La Porta, et al (1999) of other economies and more recently by Aguilera et al (2011) of firms in emerging markets have found concentrated ownership as a general pattern in most other world economies. The La Porta study which included firms from 27 developed countries concluded that only $30 \%$ of the firms showed dispersed ownership. Although Japan in this study returned dispersed ownership because of direct ownership not being higher than $20 \%$ ( the study cut-off criterion), in effect the country qualified as concentrated ownership geography because of predominant inter-corporate holdings. Aguilera et al (2011) also found significant ownership concentration, either in the form of holdings by corporate bodies, individuals or the state in their study of corporations in South America.

\section{Ownership Patterns in India}

Corporate ownership in India is predominantly concentrated in the hands of domestic individuals and promoter groups, multinational parents, or the state. Much of the family and other domestic holdings could be traced back to the days of the British Managing Agencies (Balasubramanian 2010, pp. 359-365), arguably unique to India that enabled essentially British merchants and some Indian businessmen to spawn and nurture different enterprises which eventually grew into giant corporations in their own right. Many of these 
agencies were acquired by Indian groups when their British owners chose to depart from India on the country attaining independence in 1947. The Indian state was the other major dominant shareholder in a number of large corporations when as part of national policy, state owned enterprises were set up to reach commanding heights in the Indian economy; many of these are now publicly traded corporations as a result of the government's privatisation initiatives. The third group responsible for concentrated ownership in the country is the foreign multinational sector: many international corporations have identified India along with China as the future economic power engines of the world and set up shop in the country. With several sectors of the economy gradually opening up for foreign participation, this sector may grow substantially in the near future.

While the focus of this paper is the larger publicly traded companies, it would be helpful also to recognise the phenomenal growth in the overall corporate sector in the last half a century. Exhibit-1 sets out this growth of the corporate sector in India from the time the last major legislation on company law was enacted in 1956. The listed segment out of this huge population is of course miniscule in number but significant in value: 1657 companies were listed on the National Stock Exchange as of September 2012, with a market capitalization of Rs. $64,31,658$ crores (US\$ 1.18 trillion); the much older (in fact the first Asian) Bombay Stock Exchange has a listed company population of over 5000 companies in 2012 with a market capitalization of Rs. 58, 30,000 crores (US\$ 1.06 trillion). Given the fact that some 50 to 55 thousand unlisted public companies would be virtually wholly managed by the promoters, the other absentee shareholders in those companies (although admittedly fewer in number because of the lack of public participation) would pretty much be in the same situation as the absentee shareholders in their listed counterparts, with the added vulnerability of no regulatory supervision or rigorous disclosure requirements other than what the company legislation imposes upon them. ${ }^{4}$ This continues to remain a vast unexplored segment in terms of academic research.

${ }^{4}$ The Companies Act 2013 seeks to bring about a change in this position with several good governance practices being made applicable to unlisted public companies as well; the contours of the scope and extent of these mandates are as yet unclear and would depend upon subordinate legislation in due course 
Exhibit 1: The Corporate Sector in India: 1957 - 2011

\begin{tabular}{|c|c|c|c|c|c|c|c|}
\hline & Limited by Shares & & & Unlimited & Companies & & \\
\hline 31 March & $\begin{array}{l}\text { Government } \\
\text { Companies }\end{array}$ & $\begin{array}{l}\text { Non-Government } \\
\text { Companies }\end{array}$ & Total Companies & $\begin{array}{l}\text { Liability } \\
\text { Companies }\end{array}$ & $\begin{array}{l}\text { Limited } \\
\text { Guarantee }\end{array}$ & by & Companies \\
\hline 1957 & 74 & 29283 & 29357 & - & 1364 & & 551 \\
\hline 1961 & 142 & 26007 & 26149 & - & 1169 & & 569 \\
\hline 1971 & 314 & 30008 & 30322 & - & 1270 & & 543 \\
\hline 1981 & 851 & 61863 & 62714 & 176 & 1478 & & 300 \\
\hline 1991 & 1167 & 223285 & 224452 & 317 & 2117 & & 489 \\
\hline 2001 & 1266 & 567834 & 569100 & 461 & 2918 & & 1141 \\
\hline $2011 *$ & 1316 & 713239 & 714555 & 437 & 3600 & & 3127 \\
\hline *Public & 988 & 58658 & 59646 & & & & \\
\hline *Private & 328 & 654581 & 654909 & & & & \\
\hline \multirow{2}{*}{ Listed Companies } & & & NSE 1657 & & & & \\
\hline & & & BSE $5000+$ & & & & \\
\hline
\end{tabular}

Source: Table 2.4 and XI (pp. 18, 87) $55^{\text {th }}$ Annual Report on the Working \& Administration of the Companies Act, 1956: Year ended 31 March 2011; Ministry of Corporate Affairs, Government of India; Listed companies from web sites of respective stock exchanges

\section{Concentrated vs. Dispersed Ownership}

The classical agency problem of separation of ownership and control (Fama, 1980) is commonly associated with dispersed ownership. In India where the norm is concentrated ownership in the hands of promoters, , horizontal agency or agency type-Il problems (Morck and Yeung, 2003, Roe, 2004) are more prevalent. Issues such as board composition, board monitoring, director independence, risk management, communication, disclosure practices, and so on must all be seen in this context.

\section{Voting Rights - Democratic vs. Plutocratic}

Voting rights are an index of the efficacy of ownership rights. These can be plutocratic with one vote per share or democratic with equal voting rights irrespective of the number of shares held and in some cases a combination of the two, which Alexander Hamilton (1790) referred to as the prudent mean (or regressive voting as sometimes called). A further distortion is introduced with leveraged rights with some shares being more equal than the others and commanding a higher voting impact than warranted by the single share. 
In the early $19^{\text {th }}$ century when business law followed common law, voting rights were based on the principle of suffrage rather than on the principle of property. This largely stemmed from the view that the corporation was a social entity and from a fear that plutocratic voting rights would tilt the balance of power unnaturally in the hands of the few and mighty. As capitalism became the dominant force and ownership became dispersed, plutocratic voting rights were entrenched in the US towards the latter half of the $19^{\text {th }}$ century (Dunlavy, 2006). Corporations in Germany, Britain and France also began to adopt the one vote one share principle. In India, the one vote per share principle mimicked the law in Britain, with provision for differential rights with state approval. However to this day, it is not uncommon to have a simple show of hands at a shareholders' meeting while voting on a proposal making it a democratic process at least in the ceremonial sense, since a poll (with plutocracy in full operation) must be granted if required by any shareholders. In terms of the effectiveness of the principles, neither system's superiority (democratic or plutocratic) has been established. Some countries such as the United States have both systems with large names such as Berkshire Hathaway and Google having dual class shares. In a study commissioned by the Association of British Insurers covering the FTSE 300 (ABI, 2005), Belgium and Denmark found evidence mostly supporting plutocratic voting, with $88 \%$ of the companies in Britain applying the one share-one vote principle. Countries such as Netherlands, Sweden and France had in excess of $60 \%$ of their companies listed on the FTSE with multiple voting rights, clearly an oligarchic rather than a democratic principle. In India, company legislation had prohibited issue of shares with differential voting rights right until the end of the twentieth century and then amended the law to permit them; though this practice is not very common and the number of companies with such provisions is relatively small. The Companies Act 2013 does away with this concept altogether again.

\section{Inter-Corporate Ownership - Pyramids and Groups}

The acceptance of the principle that corporations may own shares in other corporate entities was to have a monumental influence on the development and growth of what we know now as corporate groups and conglomerates. This was to be the harbinger of giant corporate entities in terms of their ultimate control over assets and resources of the total group without necessarily having to invest fully to acquire those economic interests. With a 
series of layers of holding and subsidiary or affiliate companies often with just majority control at each level, corporate pyramids were created with individuals or families or managerial clusters at the top of the cone being catapulted into positions wielding enormous control rights with comparatively little cash flow rights.

The subsidiaries and affiliates were useful (especially in case of multinational corporations) as instruments for de-risking (since each incorporated entity was deemed to be standalone legal entities with their liabilities often contained within themselves and not passing through to the parent entities, barring a few exceptions where this corporate veil could be done away with), tax saving and currency management (creatively managing profits, transferring to stronger currency and lower taxes geographies and so on), and also for genuine business strategy reasons, or to comply with local government requirements. Besides, there were also tax and other advantages in independent legal entities in case of existing businesses or geographies, or getting into joint ventures and other such structural devices.

In the context of the present study the relevance and importance of corporate groups are immense. They offer a fertile ground for potential tunneling by their controlling owners and managers through transfer of resources, profits, cash and even opportunities between firms in which their cash flow rights vary (Bertrand et al, 2000), Such abusive related party transactions take the form of interest free loans and advances, inter-corporate deposits and purchase and sale of goods and services at rates disadvantageous to the company where the group cash flow interests are lower than the other parties' where they are higher. As an example, an OECD study (2012, p. 91) of related party transactions of the top-50 companies indicated that some transactions accounted for more than $20 \%$ of the net worth of these companies. Clearly, the scale of such transactions is indeed a significant indicator of how individual company operations are routed through related group entities with potential rent extraction for the controlling shareholders.

\section{Board Interlocks}

Interlocking directorates occur where a director on one company also sits on the board of another company, thus bringing both companies together in a network of relationships. 
Interlocks could also occur indirectly: when a director a company $(A)$ sits on the boards of two other companies ( $B$ \& $C$ ), the latter two companies would be deemed to be interlocked indirectly, although none of the other directors of B and C may be sitting on each other's boards. Groups often offer more than adequate scope for interlocks between and among their own companies besides others. Concentrated ownership structures with their proclivity to disproportionately large access to control rights in corporations encourage board interlocks not only within groups but also among other similarly owned large enterprises. Thus, Balasubramanian, et all (2011) found that $6 \%$ of the total director population on the boards of NSE listed companies controlled $66 \%$ of the total NSE market capitalization in 2010. Barring a handful of professional executives, most of the directors in this $6 \%$ were from or affiliated to corporations with concentrated ownership structures.

Interlocks have both good and bad aspects, justifying their comparison with cholesterol! On the positive side they help transfer of good practices and offer win-win advice to both the companies and on the negative side, they can stifle competition and share business intelligence otherwise not easily available, respectively. In case of group interlocks, it is conceivable that the companies with better cash flow rights to the controlling promoters may benefit at the cost of others where their rights are poorer.

\section{Ownership of Indian Corporations}

A time series analysis of ownership structures in corporate India in the first decade of this millennium is presented in this section, first describing the sample for this study and the methodologies used for sourcing, validation and analysis of the data as well the subsets of sample companies for a fuller understanding of the trends and their underlying rationale. The primary data was sourced from the National Stock Exchange and related to the years ended 31 December 2001 to 2011. Three sample sets were used: (i) the top fifty companies comprising the Nifty Index, (ii) the next fifty companies comprising the "Junior Nifty" (iii) the total hundred companies in both these subsets comprising the NSE-CNX 100. These are 
described further detailed below; the main purpose of this classification was to identify the trends in the second fifty generally smaller companies in the CNX 100 index without they being swamped by the first fifty larger company set.

\section{a) NSE in the Indian Context}

The National Stock Exchange formed in 1992, has in a short time become India's largest stock exchange, bigger than its much older counterpart, the Bombay Stock Exchange. Its pioneering use of technology offered the markets a transparent trading platform for all listed securities and transformed stock trading from a location-dependent operation to a nationwide footprint where parties can buy and sell securities from anywhere in the country where technology access is available. In 2011, the exchange had 1657 companies listed with an aggregate market capitalization of Rs. 52, 32,273 crores. The NSE operates two prominent indices, among others, namely the NIFTY - 50 and the CNX-100. The following is a brief introduction to the two indices.

\section{b) The S\&P CNX-NIFTY-50}

This bellwether index was first constituted in April 1996. It is owned and managed by Indian Index Services and Products Ltd and has a license agreement with Standard and Poor (S\&P). The companies in the NIFTY-50 have nearly two thirds market capitalization (on a free-float basis $^{5}$ ) of all the stocks listed in the NSE. At present it has representation from 11 different sectors and various types of management control.

\section{c) The NIFTY JUNIOR}

This index was formed in early 2007. It represents the second fifty most liquid stocks after those in the CNX Nifty.. The companies in the NIFTY JUNIOR represent 16 sectors.

\section{d) The CNX-100}

This index was formed in early 2003. It is a combination of the NIFTY-50 and the NIFTY JUNIOR. The companies in the CNX-100 account for 16 sectors and have a combined market

\footnotetext{
5 Free float comprises the proportion of companies' equity that is available for trading; by definition it excludes promoters' holdings which are deemed illiquid and not available for public trading. The current regulatory requirement stipulates a minimum of $25 \%$ of the company's equity to be available for trading to maintain its listed status but there may be several companies which are yet to fully comply
} 
capitalization close to $80 \%$ of the market capitalization (adopting the free float methodology) of all NSE listed companies. The index is owned and managed by the Indian Index Services and Products Ltd.

\section{e) Time Frame}

A decade-plus time frame (eminently reasonable for a time series study) was chosen principally for the following three reasons:

- Economic liberalization measures initiated in 1991 (and even earlier on a relatively lower key) were further strengthened in the years that followed and began to stabilize around the turn of the century. International interest in India began to grow, especially with global majors like GE identifying India and China as the future engines of economic growth. Increased broad-based interest in corporate stocks that was unleashed (following the implementation of the Foreign Exchange Regulation Act) in the nineteen-seventies and eighties by the market entry of innumerable multinationals already operating in India on a limited scale was further cemented and catapulted by the "equity cult" that was spreading across the country, a major share of credit for which is due to the pioneering and innovative entrepreneur, Dhirubhai Ambani of Reliance Industries. ${ }^{6}$ Foreign direct investment in Indian venture steadily increased as a consequence of ongoing policy relaxations on higher foreign shareholding limits in many sectors. Also, as part of the government's disinvestment programmes, many public sector corporations including banks were listed on stock exchanges boosting both available securities and their active trading, with Indian and Foreign Institutional Investors contributing handsomely. The country had also shed its antagonistic posture against private sector businesses and was willing to openly live with concentration of economic power in the hands of business houses, a concept that was anathema in the decades following political independence. Globalisation initiatives led to recognition of the needs for corporate consolidation through mergers and acquisitions inevitably bringing in their wake

\footnotetext{
6 Between 1980 and 1985, the number of Indians owning shares increased from less than a million to some four million. The number of shareholders in Reliance Industries alone rose to more than a million by 1985 (McDonald 1998, p.56)
} 
issues of contestability of corporate control. The first decade of the new millennium thus offered a rich timeframe to explore ownership trends in companies accounting for a sizable slice of market capitalization.

- Reporting and disclosure norms for listed corporations had been substantially improved alongside significant prescriptive improvements in the governance of listed corporations, effected through their listing agreements with stock exchanges. These substantially enhanced the availability and richness of detail of authentic information from company filings with respective stock exchanges. For example, without the ownership data by categories available now in company filings, a study of this nature and on this scale would have been extremely difficult and time consuming if not virtually impossible to pursue.

- Corporate ownership, and hence control, in India is predominantly concentrated in the hands of a few, sponsors or promoters, unlike say in the US and UK. Also, there has been a very visible movement in many countries away from retail or individual shareholders towards institutional investors like pension funds and mutual funds. The insurance and mutual funds sector had been a state monopoly for the Life Insurance Corporation and Unit Trust of India for most of the post-independence decades until private sector entities were allowed entry at the turn of the century; this together with the advent of foreign institutional investors in the Indian capital market following gradual economic liberalisation beginning 1991 enabled multiple institutions to invest and participate in the Indian corporate sector. Having reached a measure of stability over the years, their presence and operation in the chosen time frame would help identify if and to what extent such a trend towards institutional investors away from retail investors was discernible in the publicly traded Indian corporate sector.

\section{f) Data review and validation}

First the list of companies forming the NIFTY and CNX-100 over a period of eleven years (2001-2011) was obtained from the NSE archives. The CNX-100 did not exist prior to 2004 and as a result the NIFTY-50 and the NIFTY JUNIOR were combined together to arrive at a list of 100 companies, in line with the methodology followed by the NSE, for the years 2001- 
2004. Ownership data was obtained primarily from NSE based on company filings as of December 31 each year. There were some blanks especially in some of the earlier years of the study time frame; and also there were instances where the year-on-year changes were striking. In such cases, information from multiple other sources - Prowess, Capital Line and company web sites were consulted to validate the data sets. Although ownership data were available in both absolute numbers and percentages, the later figures were used for processing and analysis since this study's objective was to ascertain proportions of equity holding by different categories of shareholders and to determine trends in ownership and explore to the extent possible their underlying circumstances.

Size-wise, the sample covers 189 companies which have been part of the Nifty and 100 indices at some time or the other during the study time frame. Membership of the index list is not permanent and hence the composition changes from time to time; this explains the additional 89 companies compared to the normative size of 100 on the index at any time. Only 20 and $\mathbf{2 9}$ companies respectively have been continuously on the NIFTY and CNX-100 during the entire time frame of the study.

\section{Classification of Companies}

For purposes of our analysis, sample companies have been classified under four categories based on the type of ownership and control. Exhibit-2 sets out our grouping of the sample companies, further described below.

\section{Domestic Private Sector Companies}

These are companies that are substantially (but not necessarily majority) owned and controlled by India based groups, individuals, or families. These holdings are classified as "promoter" owned according to definitions prescribed by SEBI and adopted in company filings with stock exchanges and include holdings by associates disclosed as acting in concert with the promoters. 


\section{Foreign Private Sector Companies}

This category comprises of firms that are controlled by foreign based groups or holding companies including those controlled by foreign based Indian families and individuals, and acting in concert. Subsidiaries and affiliates controlled by multinational corporations form part of this group.

\section{Government Owned Companies}

This category comprises of firms that have state or central governments as the majority shareholder. Also included are firms where majority shareholding rests with a government controlled institutional entity such as the Reserve Bank of India (in case of State Bank of India). The classification is based on respective company filings and descriptions.

\section{Management Controlled Companies (Dispersed shareholdings)}

These companies comprise of entities with no identifiable controlling promoters as described in their filings. Shareholders in these companies are institutional investors and retail investors with no role to play in operational management and control of the companies. $^{7}$

\section{Exhibit 2: Types of Companies}

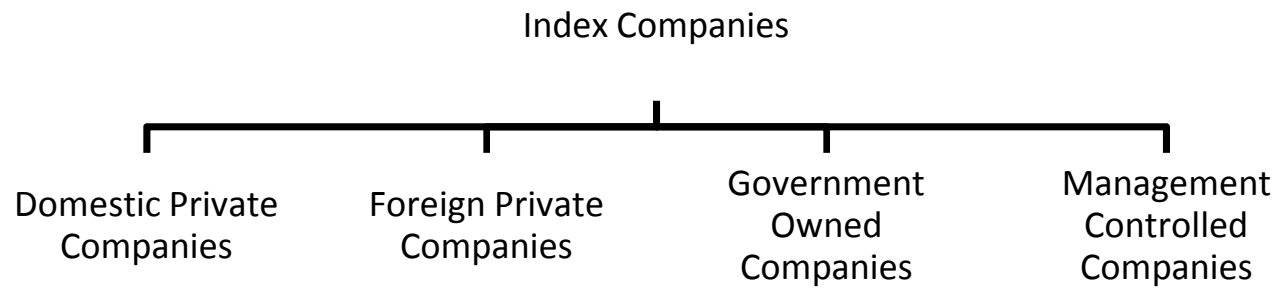

\footnotetext{
${ }^{7}$ In some of these companies (for example, Larsen and Toubro), there were very small proportions of holdings classified as promoters' probably representing the residual remnants which originally belonged to the promoters; they were however not material enough to control the company
} 


\section{Classification of Shareholders}

Data was also analysed under four major categories of shareholders in the sample companies namely (i) Promoters, (ii) Institutional Investors, (iii) Non- Institutional Investors, and (D) Government. SEBI guidelines define Promoters as individuals or companies owning more than $20 \%$ in the equity capital of the company. For the present study promoters can be Indian, Foreign or the Government. In case the promoter is the Central or State government, then this shareholding has been classified as Government. So while promoter shareholding can appear across Domestic Private Companies, Foreign Private Companies and (to an insignificant extent, Management Controlled Companies), Government shareholding is relevant only in Government companies. Institutional Investors both domestic and foreign, Mutual Funds, Venture Capital Funds and so on can figure across all the four categories of companies. Similarly Non-Institutional shareholding consisting of Corporate Bodies, Individual Shareholders, NRIs and Foreign Nationals can appear across all company categories.

\section{Exhibit 3: Classification of Share Ownership}

Domestic

Ownership Type Private Company Foreign Private Company

$*$ Promoter

Government Institutional

NonInstitutional

*

Statistical analyses that follow have been structured as follows: 
- The first slicing of the data was on the basis of the two sub-sample sets, depending upon the profile of the companies: the first category (Set A) comprised companies in the respective indices at 31 December each year; and the second category (Set B) comprised companies that were in the respective indices as of 31 December 2011 tracked over the time period 2001-2011 (since some of these companies were not listed in the early years, this the number of companies add up to 50 for the NIFTY and the JUNIOR NIFTY and 100 for CNX-100 only in the later years). The first category was to gauge the ownership status in respect of each year's index population; the findings in this category would be influenced not only by changes in continuing companies but also the ownership patterns of incoming and outgoing companies. The second category was to ascertain ownership movements in balanced sets of companies to discern historical trends over time in changes over the study period without being affected by changes attributable to incoming and outgoing companies.

- Within these two broad sets, the second slicing was by the indices they were part of: Nifty, Junior Nifty and 100 . This was to ascertain the changing patterns among the three index groups.

- The third slicing was to derive for each of these six data sets (first slicing of two multiplied by the second slicing of three), summaries of ownership movements in fourteen categories comprising mean and median statistics in respect of the total sample in the category, the four company classifications (domestic private, foreign private, government, and management control) and two investor categories (institutional and non-institutional retail). There are thus a total of $(2 * 3 * 14) 84$ exhibits (of graphics and tables) that are presented in the Annexure. A schematic of this analytical structure is displayed in Exhibit-4. 


\section{Exhibit 4: Schematic of Analytics Structure}

\section{Set A}

Index Companies as of December $31^{\text {st. }} 2001$ to 2011 $N=50 / 50 / 100$

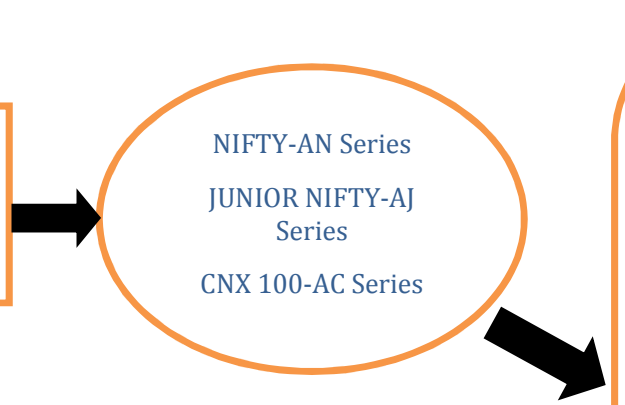

\section{Set B}

Index Companies as of December 2011 and Preceding 10 years whether or not in Index

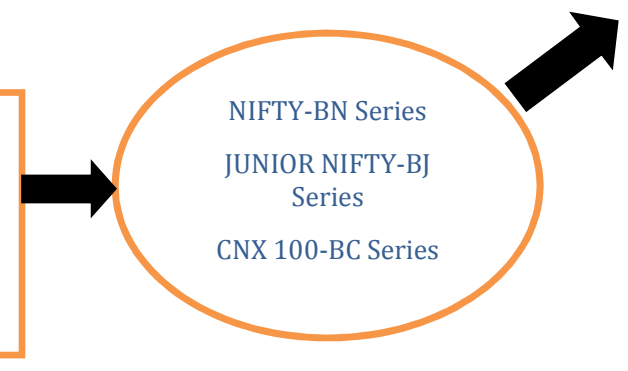

Graphs-14 Types for each Index within each Set

\section{All Companies Mean Ownership Trends}

All Companies Median Ownership Trends

Domestic Pvt. Companies Mean Ownership Trends

Domestic Pvt. Companies Median Ownership Trends

Foreign Pvt. Companies Mean Ownership Trends

Foreign Pvt. Companies Median Ownership Trends

Government Owned Companies Mean Ownership Trends

Government Owned Companies Median Ownership Trends

Management Controlled Companies Mean Ownership Trends

Management Controlled Companies Median Ownership Trends

Institutional Ownership Mean Ownership Trends

Institutional Ownership Median Ownership Trends

Non-Institutional Ownership Mean Ownership Trends

Non-Institutional Ownership Median Ownership Trends 
III

\section{Analysis and Observations}

While the exhibits in the annexure set out detailed charts and statistical information, this section outlines the key findings and observations flowing from this study. Although, for reference purposes, the annexure exhibits provide both mean and median information, this discussion is based only on median statistics, given the general problems of outliers vitiating arithmetical averages in such analyses. We first deal with the Set A companies that were part of the Nifty and CNX 100 each year (hence disparate panels of companies) and then Set B companies comprising those in the Nifty and CNX 100 as of 2011 and their respective data for the preceding ten years (hence a balanced panel of companies).

\section{Set A: Index Companies at Each Year-end:}

- The composition profile of the Index companies has recorded a major structural shift during the study time frame. In the Nifty, government companies moved up from 7 in 2001 to 10 in 2001 with a decline in foreign private companies from 11 in 2001 to 8 in 2011. In the larger CNX 100 index, this pattern was even more pronounced with government companies going up from 10 to 22 and foreign companies declining from 27 to 14 between 2001 and 2011. This escalating predominance of government companies has huge implications for the protection of absentee shareholders' interests, given the government's disclosed powers to inflict costs on their controlled companies in public interest. ${ }^{8}$

\footnotetext{
8The Coal India Ltd case (sub judice) is a recent example where absentee shareholders have taken umbrage in respect of government directives prejudicial to their interests
} 
Exhibit 5A: Count of Companies in the CNX-Set A

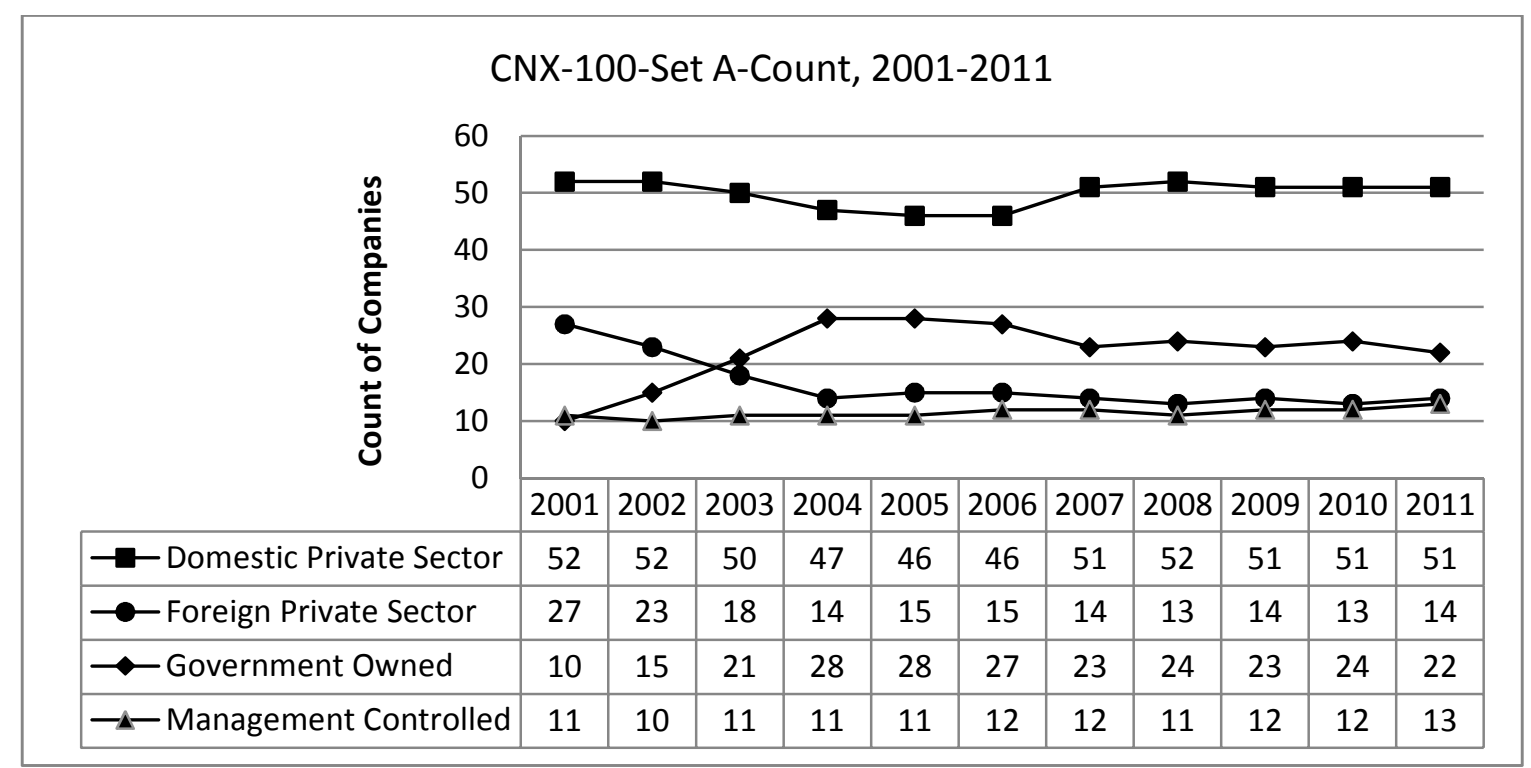

Exhibit 5B: Count of Companies in the NIFTY-Set A 


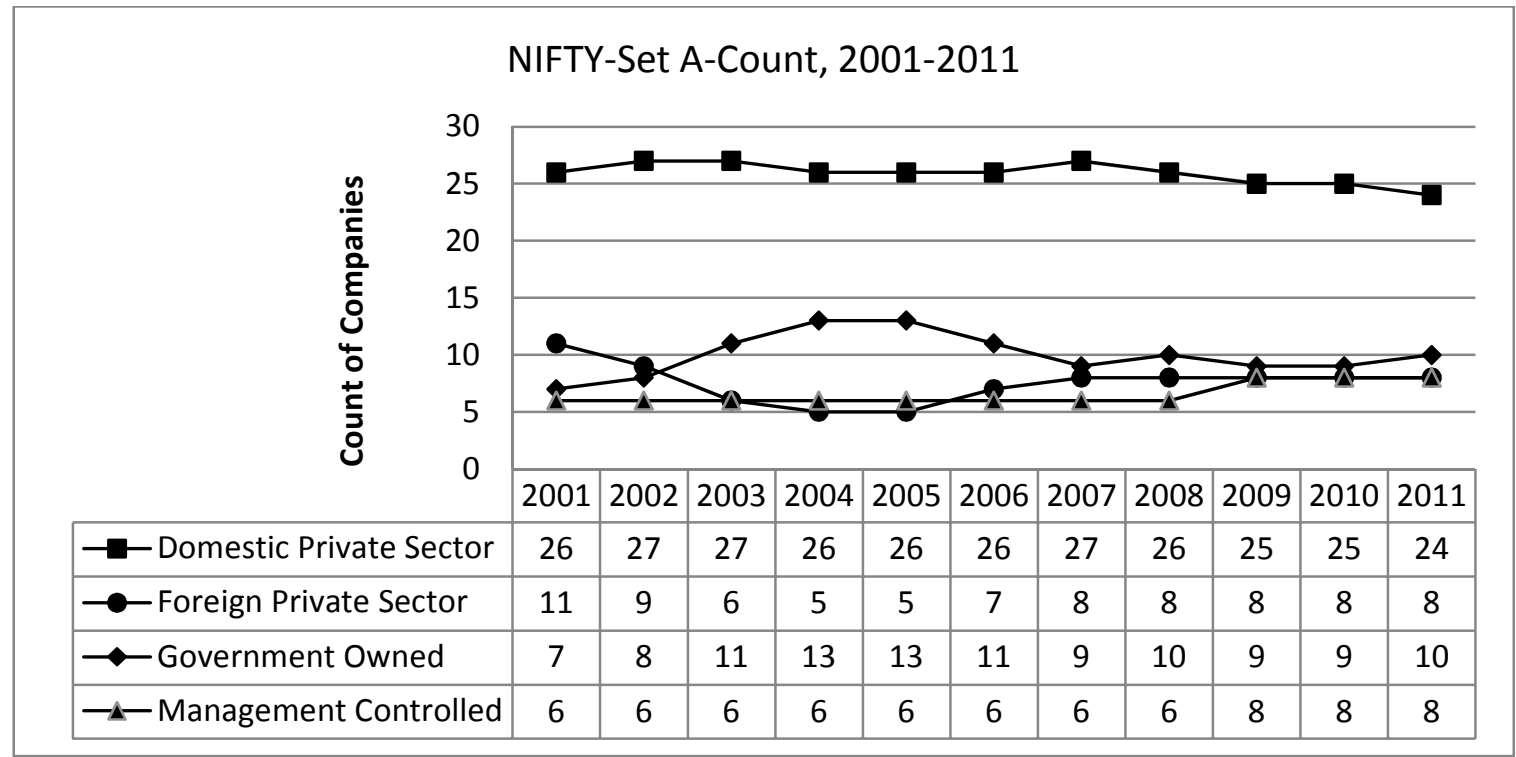

Exhibit 5C: Count of Companies in the JUNIOR NIFTY-Set A

\begin{tabular}{|cc|c|c|c|c|c|c|c|c|c|c|c|}
\hline \multicolumn{1}{|c|}{ JUNIOR NIFTY-Set A-Count, 2001-2011 } \\
\hline
\end{tabular}

- There is empirical confirmation of the predominance of concentrated ownership and control in corporate India. Not only that but also the extent of such concentration over the years was increasing. Thus, although out of the fifty Nifty companies the number of dominant ownership entities (domestic, foreign and government) had gone down to forty two in 2011 from forty four in 2001, the median holdings of controlling shareholders had gone up to $56.24 \%$ in 2011 from $42.94 \%$ in 2001. In the larger CNX 100 sample, the number of such companies remained unchanged at 86 , median promoter holdings has gone up from $48.83 \%$ in 2001 to $54.21 \%$ in 
2011.Entry in to the Index cluster of new companies some with higher promoter holdings is a possible contributory to the escalation in promoter ownership. For example, entry in to the Nifty of three additional government companies with significant promoter ownership would reflect in the overall Nifty median promoter ownership numbers. Besides, some reclassifications of holdings from the institutional to the government category in the earlier years would also have the same effect. ${ }^{9}$

- Domestic private companies as a class did escalate their promoter holdings substantially over the period: median holdings in Nifty going up from $28.50 \%$ in 2001 to $46.80 \%$ in 2011. (AN-4); in Junior Nifty from 36.67\% in 2001 to $45.98 \%$ in 2011 (AJ4) and in CNX 100 from $32.08 \%$ to $46.75 \%$ (AC-4). One implication could be that given the more relaxed political and regulatory attitude towards control contestability, these companies had to gradually bolster their holdings as a defence against possible unsolicited takeover attempts.

- Foreign controlled companies in the Nifty, although three less in number in 2011 compared to 2001, actually recorded an increase in promoter ownership from $51 \%$ in 2001 to $53.36 \%$ in 2011 (AN-6). On the other hand, such companies in the Junior Nifty showed a decrease from 52.82\% in 2001 to $51.00 \%$ in 2011 (AJ-6), thus neutralsing the effect on the corresponding numbers in CNX 100 with median numbers remaining virtually unchanged: 51.01\% in 2001 and 51.76\% in 2011 (AC-6).

- Non-Institutional retail shareholdings, in line with experience elsewhere in the developed world have recorded a steep decline during the study period: in the Nifty panel, the median holding fell to $16.15 \%$ in 2011 from $28.82 \%$ in 2001 . The Junior Nifty companies recorded an even greater decline; from 31.21\% in 2001 to $15.88 \%$ in 2011.The CNX 100 group reflected this trend, the median numbers falling from $30.29 \%$ in 2001 to $15.96 \%$ in 2011.

\footnotetext{
9 For instance, holdings in Kochi Refineries and State Bank of India held by other government owned entities like Bharat Petroleum and Reserve Bank of India respectively were rightly reclassified as government holdings in later years.
} 
- Not all of this migration, however, was to institutional shareholdings which remained virtually unchanged at $30.15 \%$ in 2001 and 30.31 in 2011. Within the two groups though, there were significant differences between the Nifty and the Junior Nifty companies: median numbers in Nifty were 30.15\% in 2001 and 30.31 in 2011;Junior Nifty companies, on the other hand, recorded a different trend with median numbers increasing from 16.57 in 2001 to 27.58 in 2011 (AJ-2). This would seem natural since the promoters in Junior Nifty companies overall did not feel the necessity to increase their holdings, already being at comfortable levels.

- The migration of non-institutional shareholdings in case of domestic private companies reveals a similar trend. In the Nifty group, median institutional shareholdings recorded little change: 33.04\% in 2001 and 30.77\% in 2011 (AN-4), confirming absorption of the migration from non-institutional shareholding, much of it through buybacks with promoters not participating and, in some cases, through open offers following acquisitions. ${ }^{10}$ But in case of Junior Nifty companies, median institutional holdings shot up from $15.25 \%$ in 2001 to $28.07 \%$ in 2011 (AJ-4).

- The churn in the Junior Nifty companies during this period also likely influenced these statistics; for example, included in this churn is a substantial reduction in foreign companies through de-listing and preferential allotments and a corresponding increase of government companies replacing them could have affected both the promoter and non-institutional retail shareholdings. ${ }^{11}$

${ }^{10}$ For example Aditya Birla Nuvo offered share buybacks to increase holdings from 39\% (2007) to 50\% (2011)

11 The Government companies in the sample grew from 10 in 2001 to 22 in 2011 . The mean promoter holdings went from $60 \%$ to $67 \%$ within this period, 
Frequency Distribution of Promoter/ Government Holding in All Index Companies

Exhibit 6A: Frequency Distribution of Promoter/Government Companies in CNX-100

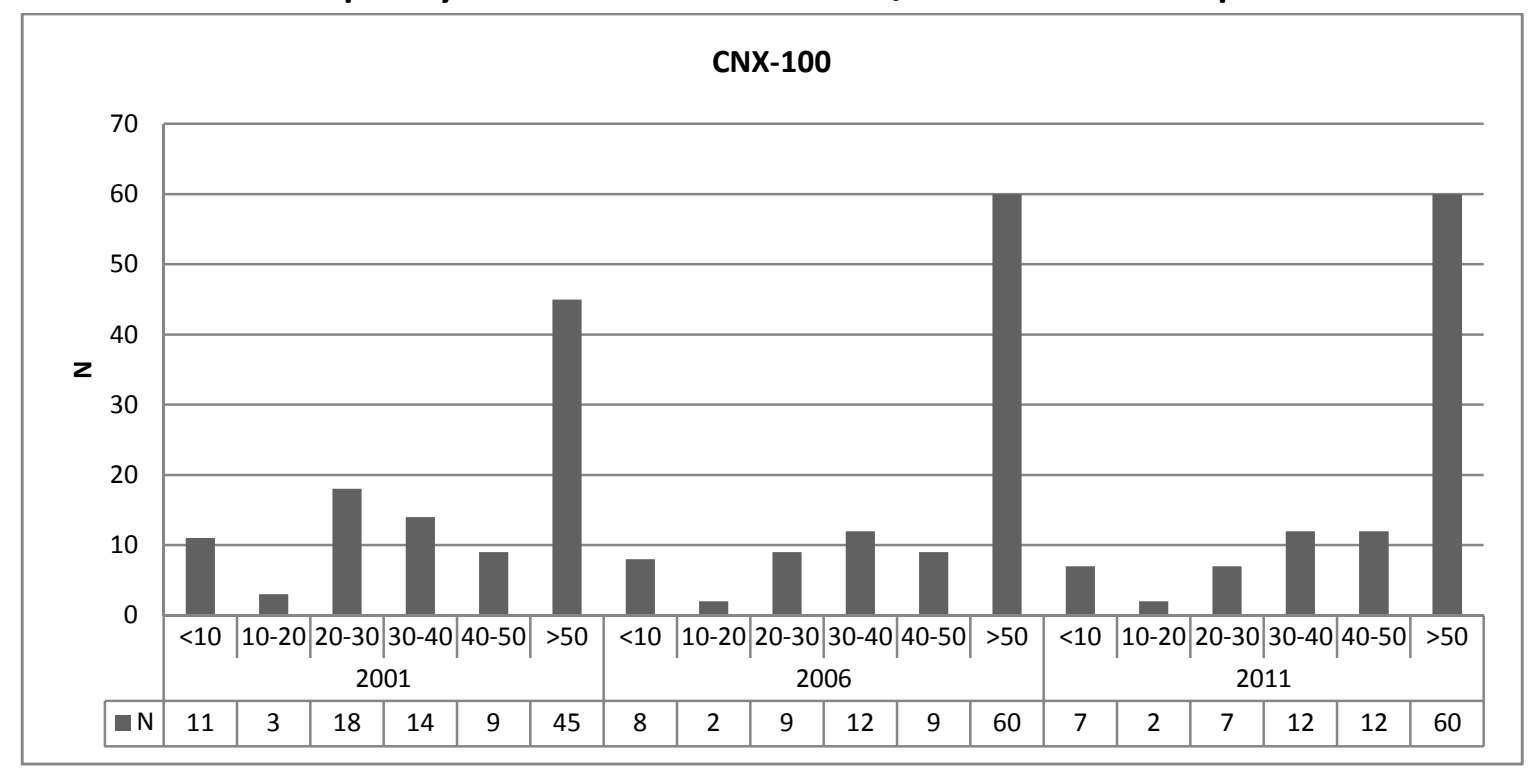


Exhibit 6B: Frequency Distribution of Promoter/Government Companies in NIFTY

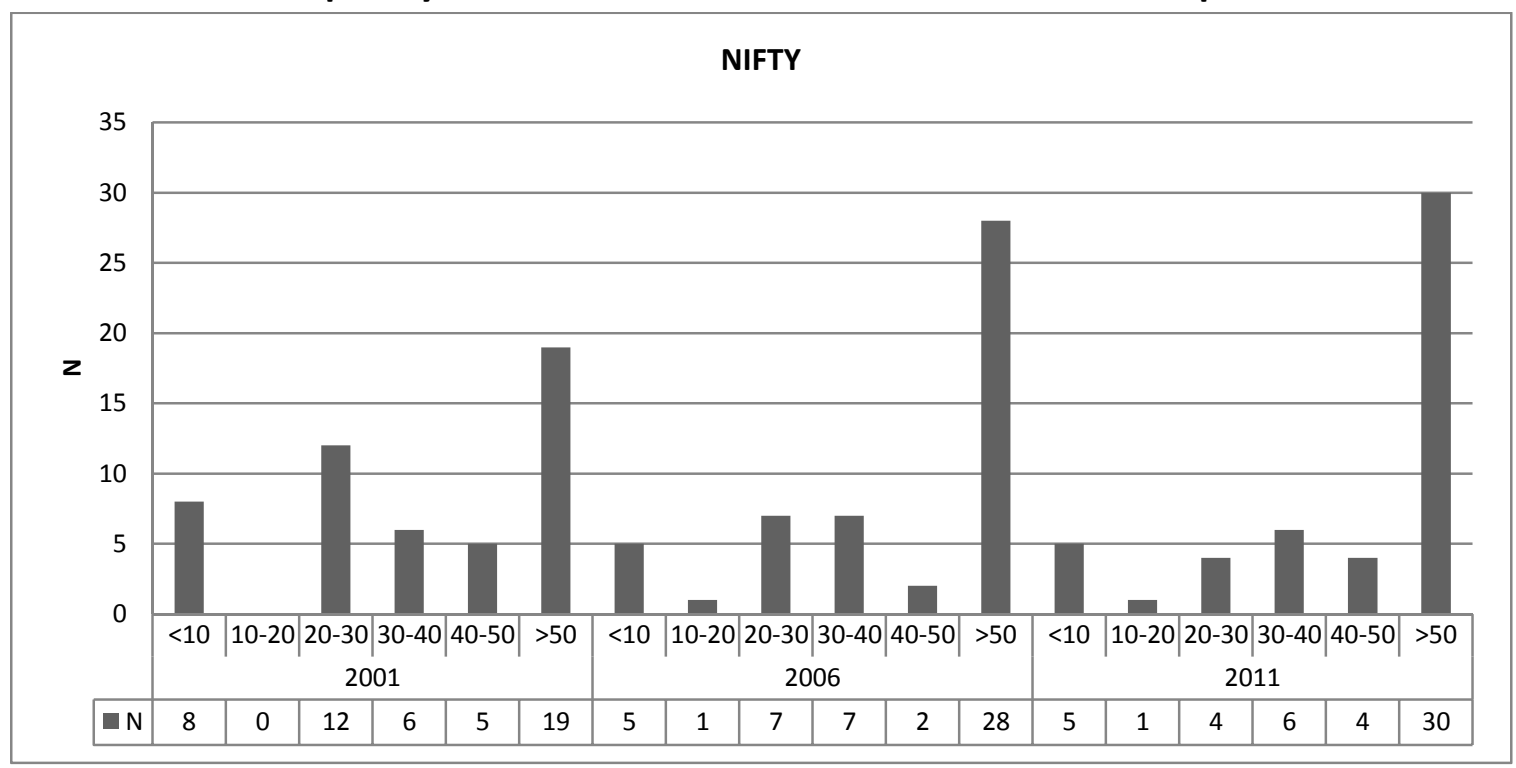

Exhibit 6C: Frequency Distribution of Promoter/Government Companies in NIFTY JUNIOR

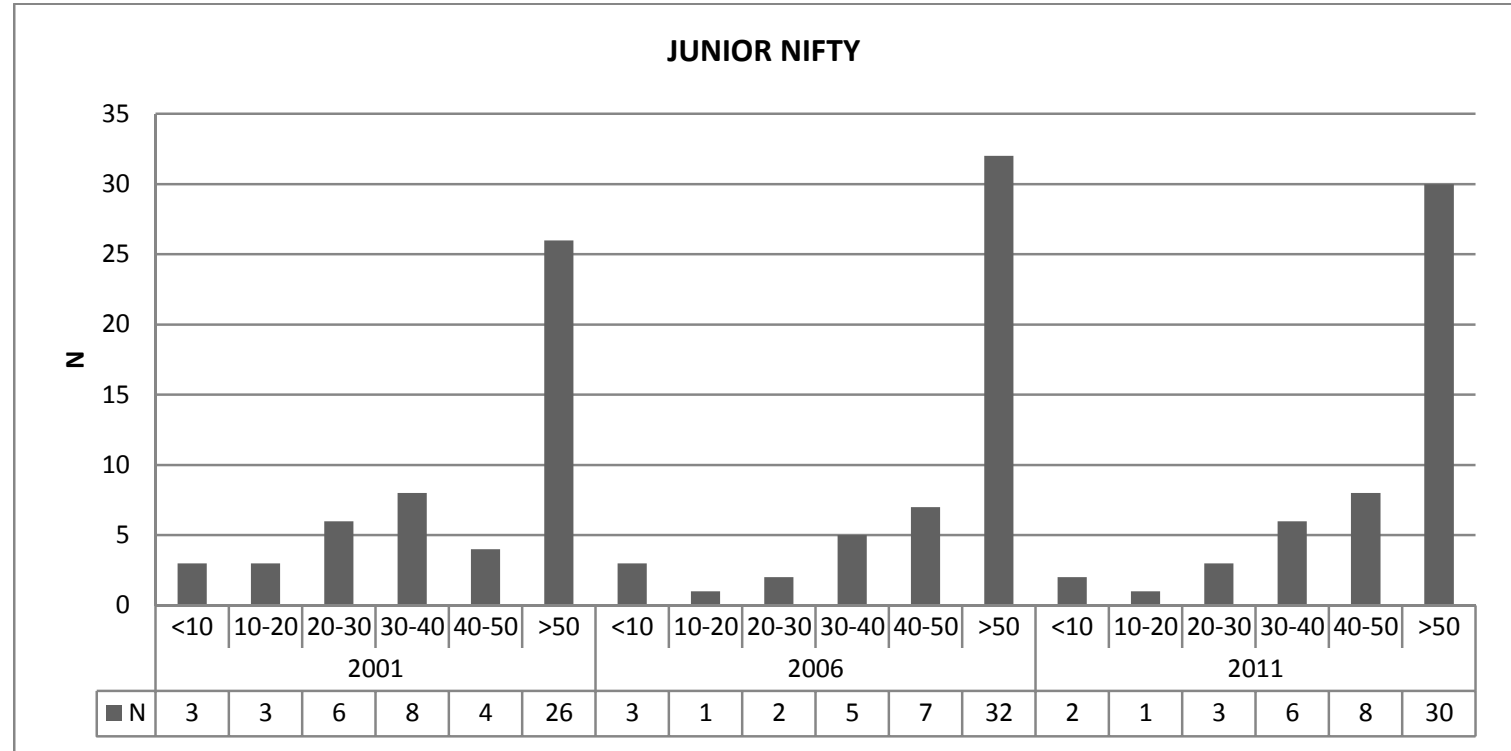

- The simple frequency distribution of promoter holdings in the index companies shows that companies with promoter holdings $>50 \%$ have increased in all three indices between 2001 and 2011. Within the CNX-100, 45 companies had promoter holdings in excess of 50\%. This increased to 60 companies in 2006 and 2011. Within the NIFTY-50 companies this number went up from 19 in 2001, to 28 in 2006 and 30 in 2011. With reference to the JUNIOR NIFTY companies, the number of companies with more than 50\% promoter holdings was 26 in 2001, went up to 32 in 2006 and was 30 companies in 2011. The absolute increase between 2001 and 2011 in the 
number of companies with more than $50 \%$ promoter holdings provides strong support to the fact that promoter holdings have increased over the 10 year period.

\section{Set B: Index Companies in 2011 over Ten Preceding Years}

- As noted earlier, this set comprises a uniform panel of companies (based on index companies in 2011) comprising ten earlier years' data. This profile is helpful in tracking the structural changes in individual companies over time and ascertaining trends in Nifty, Junior Nifty and CNX 100. Key findings, again based on median data, are enumerated below:

- In terms of composition, this set had in the CNX 100, 51 companies in the domestic private group, 14 in the foreign private group, 22 in the government group and 13 in the management controlled group in the base year 2011. The profile should have remained unchanged in all the years since the same company history is what was being tracked. In practice though, there were two exceptions where a domestic private company through acquisitions were reclassified as foreign private companies. ${ }^{12}$ Also to be noted is that all the companies in 2011 had not been listed in 2001. As a result $N$ values increased over the years finally reaching 100 in 2010.

12These were Ambuja Cements (2006) and Ranbaxy Laboratories (2008), following acquisition respectively by Holcim and Daiichi Sankyo 
Exhibit 7A: Count of Companies in the CNX-Set B

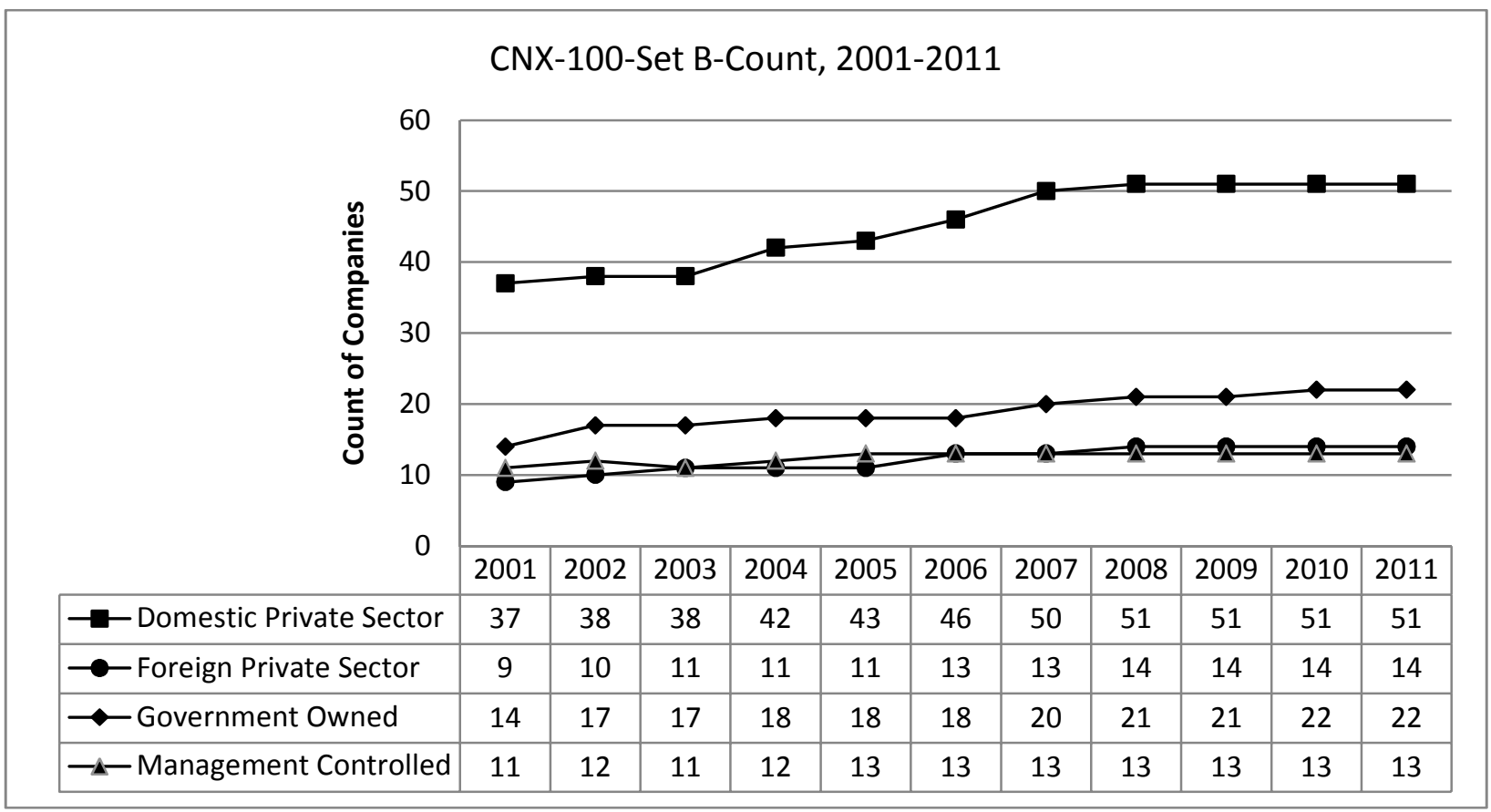

Exhibit 7B: Count of Companies in the NIFTY-Set B

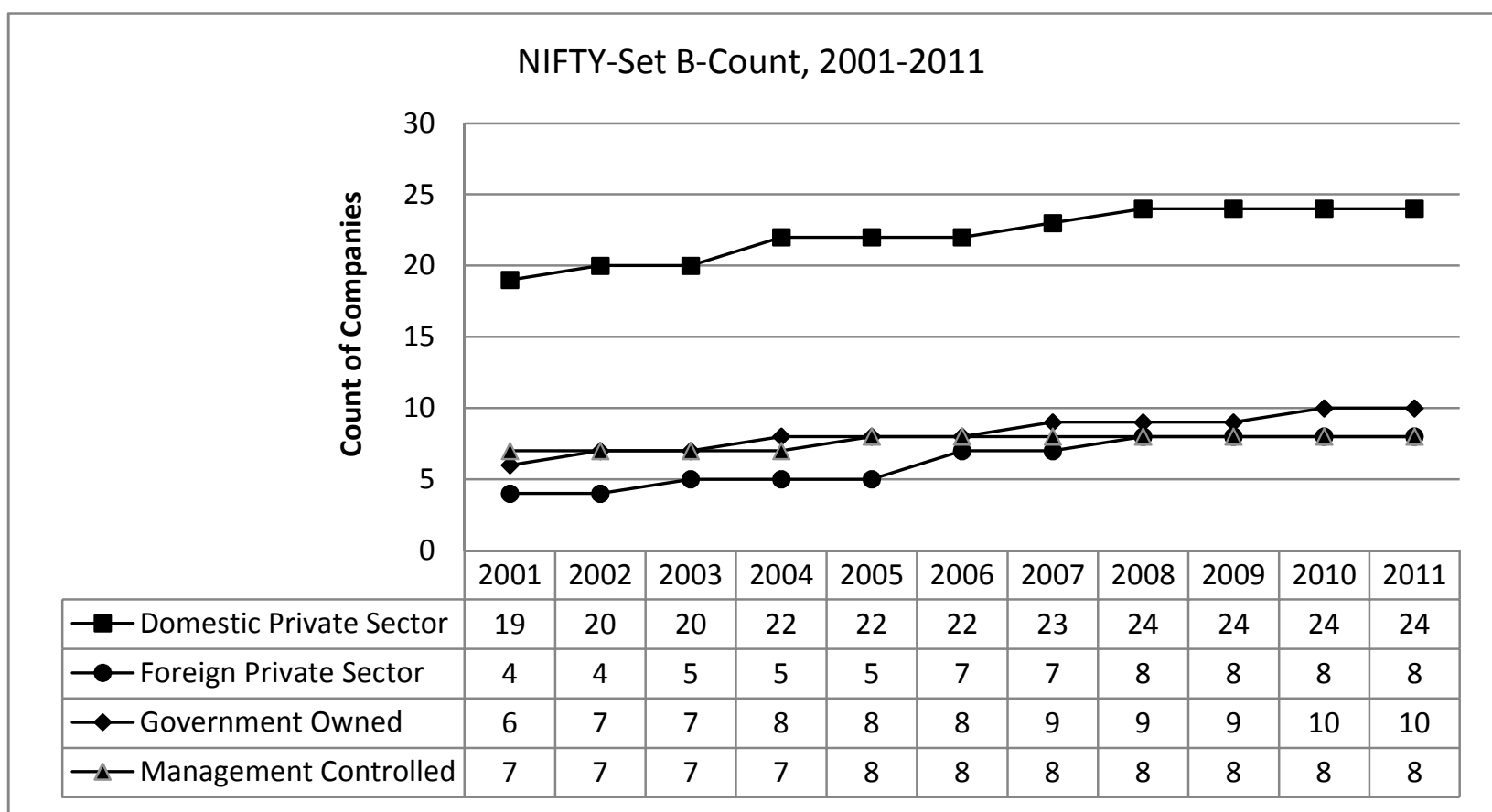


Exhibit 7C: Count of Companies in the JUNIOR NIFTY-Set B

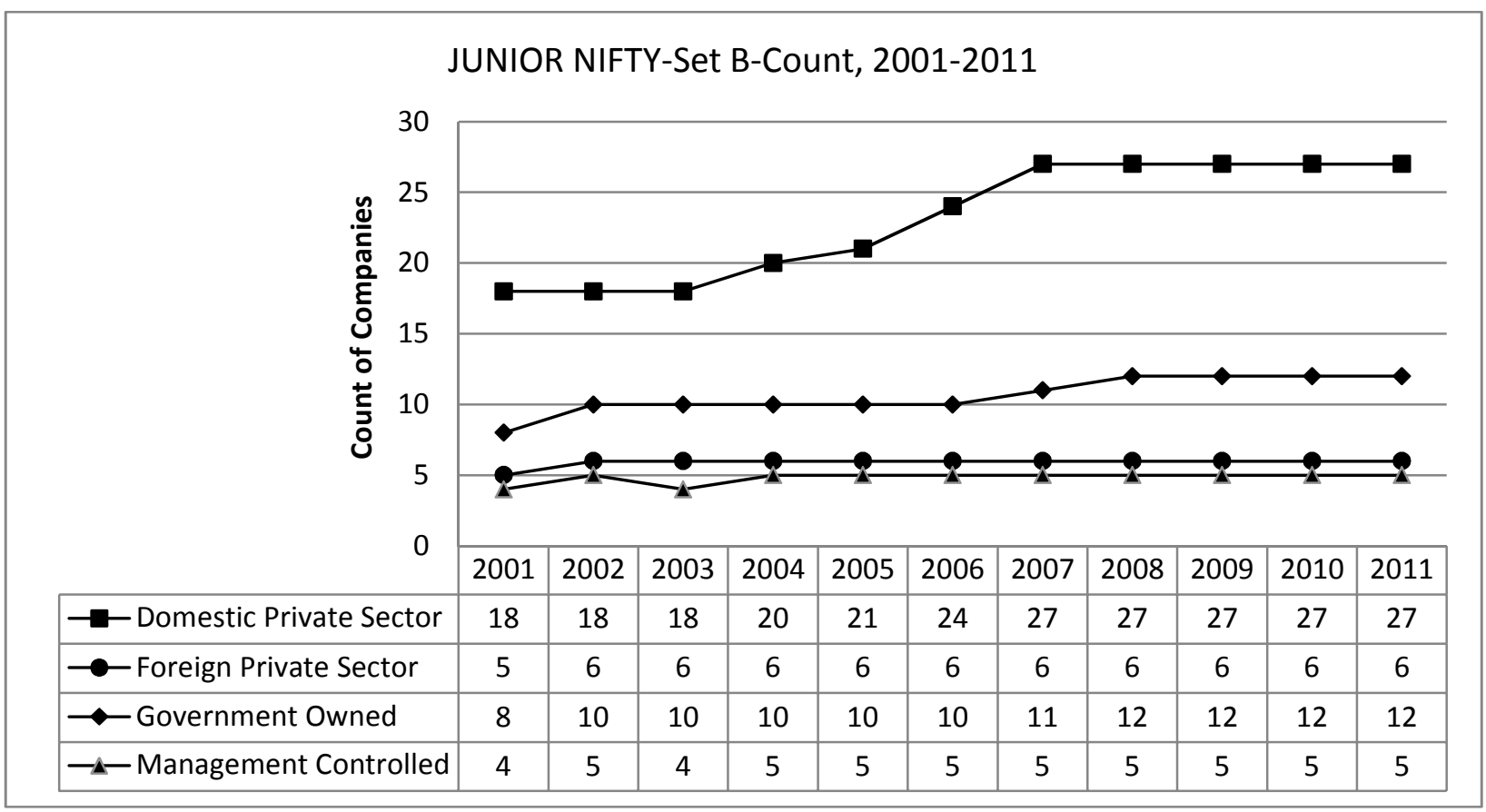

- Promoter ownership registered steep increases in the Nifty set from $25.99 \%$ in 2001 to $38.19 \%$ in 2011 (BN-2), and in the CNX 100, from 30.53\% in 2001 to $41.69 \%$ in 2011 (BC-2). In the Junior Nifty companies though there was little change: from 42.41\% in 2001 down to $42.06 \%$ in 2011 (BJ-2). As noted in the Set A comments, these Junior Nifty companies starting with a fairly comfortable promoter holding, perhaps had little pressure to increase their holding as a takeover defence.

- Within the Nifty group, promoters of domestic private companies hiked their median holdings steeply from 26.41 in 2001 to 46.80 in 2011 (BN-4). ${ }^{13}$ The Junior Nifty group of domestic private companies on the other hand recorded only a modest increase with their median promoter holdings going up from $42.51 \%$ in 2001 to $45.98 \%$ in 2011 (BJ-4) tempering corresponding numbers in the entire CNX 100 group to an increase from $32.55 \%$ in 2001 to $46.75 \%$ in 2011 (BC-4).

\footnotetext{
${ }^{13}$ For example, companies such as Jindal Steel and Power and Hero Motor Corporation saw an increase in promoter holdings by as much as 25\% between the years 2001 and 2011.
} 
- Non-Institutional holdings in this set saw major decline with median holdings in the CNX 100 falling from $28.71 \%$ in 2001 to $15.95 \%$ in 2011; within this, the Nifty companies $^{14}$ virtually halved their median non-institutional holdings from $32.25 \%$ in 2001 to $16.14 \%$ in 2011 while in the Junior Nifty group, the fall was less severe from $25.58 \%$ in 2001 to $15.88 \%$ in 2011 . Within this, domestic private companies' decline was more severe in the Nifty than in the Junior Nifty: median non-institutional shareholdings in the Nifty fell from 33.54 in 2001 to 19.33 in 2011 (BN-4) while in the Junior Nifty they fell from31.09 to $20.07 \%$ (BJ-4). As in the case of Set A companies, here also much of this migration was to bolster promoters' shareholdings in the Nifty group while a substantial part went to institutional investors in the Junior Nifty group.

- Foreign companies as a group in this Set saw negligible movement in promoter holdings during the study period. Non-institutional shareholdings however recorded a steep decline in Nifty where they fell from 30.36\% in 2001 to 15.68\% in 2011 (BN6), while the fall in Junior Nifty was much more modest, from $17.31 \%$ in 2001 to 16.24\% in 2011 (BJ-6), leading to a combined CNX 100 numbers of 25.58\% in 2001 and 16.09\% in 2011 (BC-6). Much of these released holdings were picked up by institutional shareholders with some part being absorbed by the promoters mostly through open offer purchases following acquisitions. ${ }^{15}$

- Government companies in this Set witnessed some significant migration from noninstitutional to institutional shareholders largely in the Junior Nifty group: from $18.33 \%$ in 2001 to $10.71 \%$ in 2011 in the non-institutional category and from $12.39 \%$ in 2001 to $25.20 \%$ in 2011 in the institutional category (BJ-8). ${ }^{16}$

- The 13 management controlled companies in this set witnessed a steep escalation in institutional holdings from 35.22\% in 2001 to $51.09 \%$ in 2011 (BC-10) with corresponding decline in non-institutional shareholdings. While eight such

\footnotetext{
${ }^{14}$ For example, Non-Institutional holdings in ACC fell by $39 \%$ and slightly more than $50 \%$ in the case of Jindal Steel and Power between the two years 2001 and 2011

${ }^{15}$ For example, Institutional Holdings in the Kotak Mahindra Bank increased by $30 \%$ while in HCL Technologies it increased by nearly $18 \%$

${ }^{16}$ For example Andhra Bank and the Bank of India saw more than $20 \%$ increase in Institutional Holdings while Non-Institutional holdings went down by $13 \%$ and $11 \%$ respectively
} 
companies in Nifty witnessed a steep increase in this category from 40.88\% in 2001 to $53.25 \%$ in 2011 (BN-10), the escalation in the five such companies in Junior Nifty was staggering, from $7.95 \%$ in 2001 to $42.42 \%$ in 2011 (BJ-10). ${ }^{17}$

\section{Frequency Distribution of Promoter/ Government Holding in All Index Companies}

Exhibit 8A: Frequency Distribution of Promoter/Government Companies in CNX-100

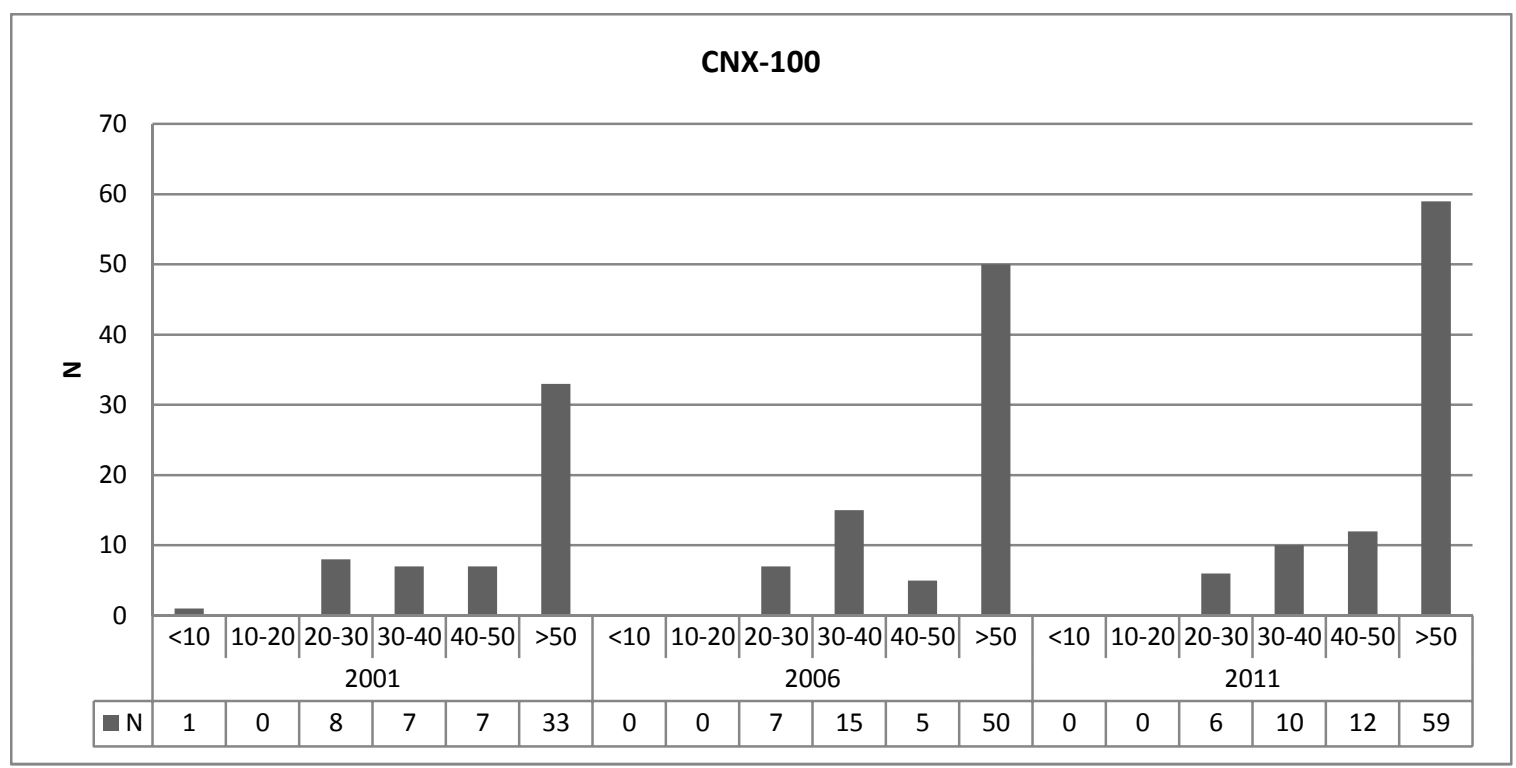

Exhibit 8B: Frequency Distribution of Promoter/Government Companies in NIFTY

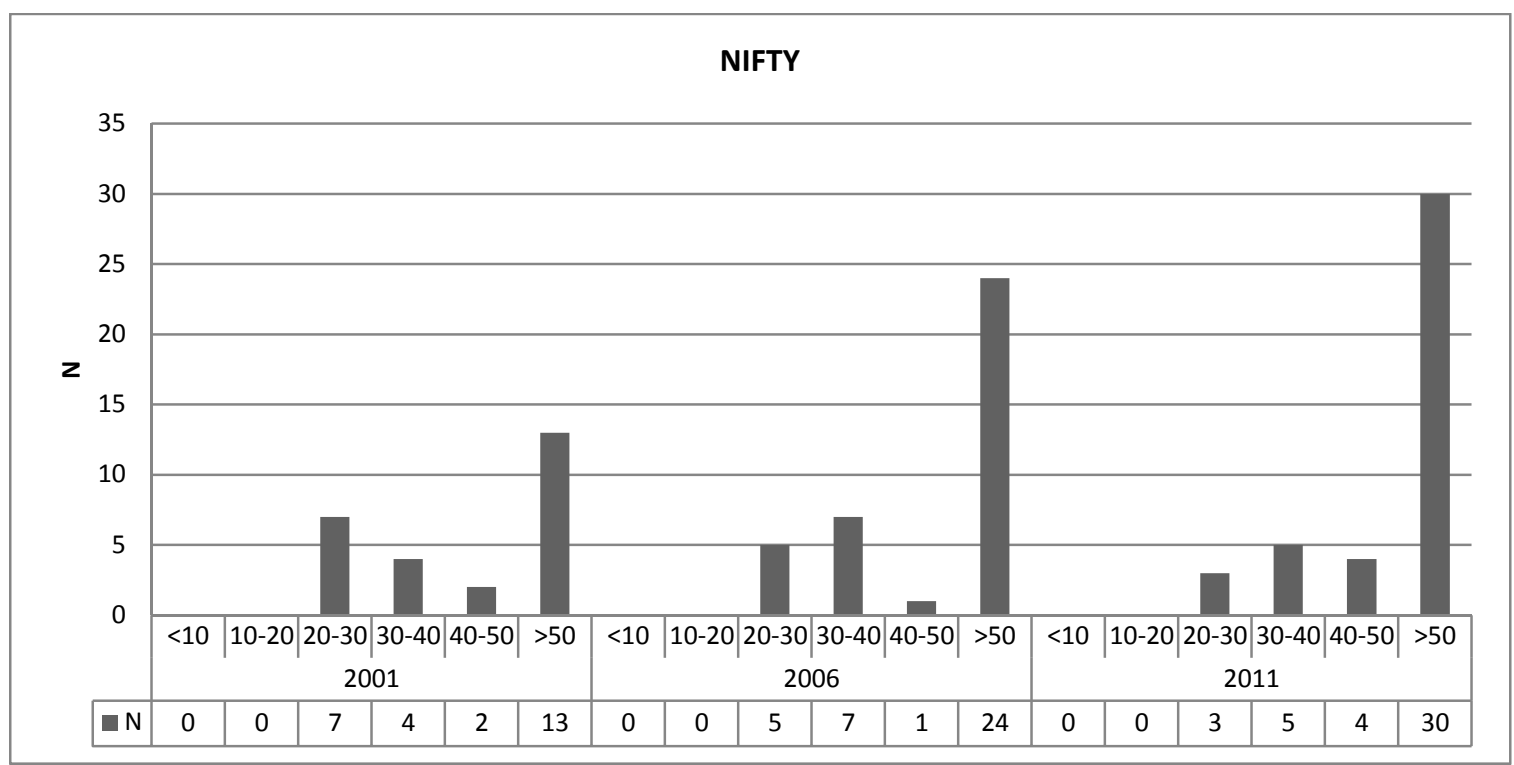

${ }^{17}$ Federal Bank, Indus Ind Bank and Mphasis saw drops in excess of $40 \%$ in the Non-Institutional shareholding 
Exhibit 8C: Frequency Distribution of Promoter/Government Companies in NIFTY JUNIOR

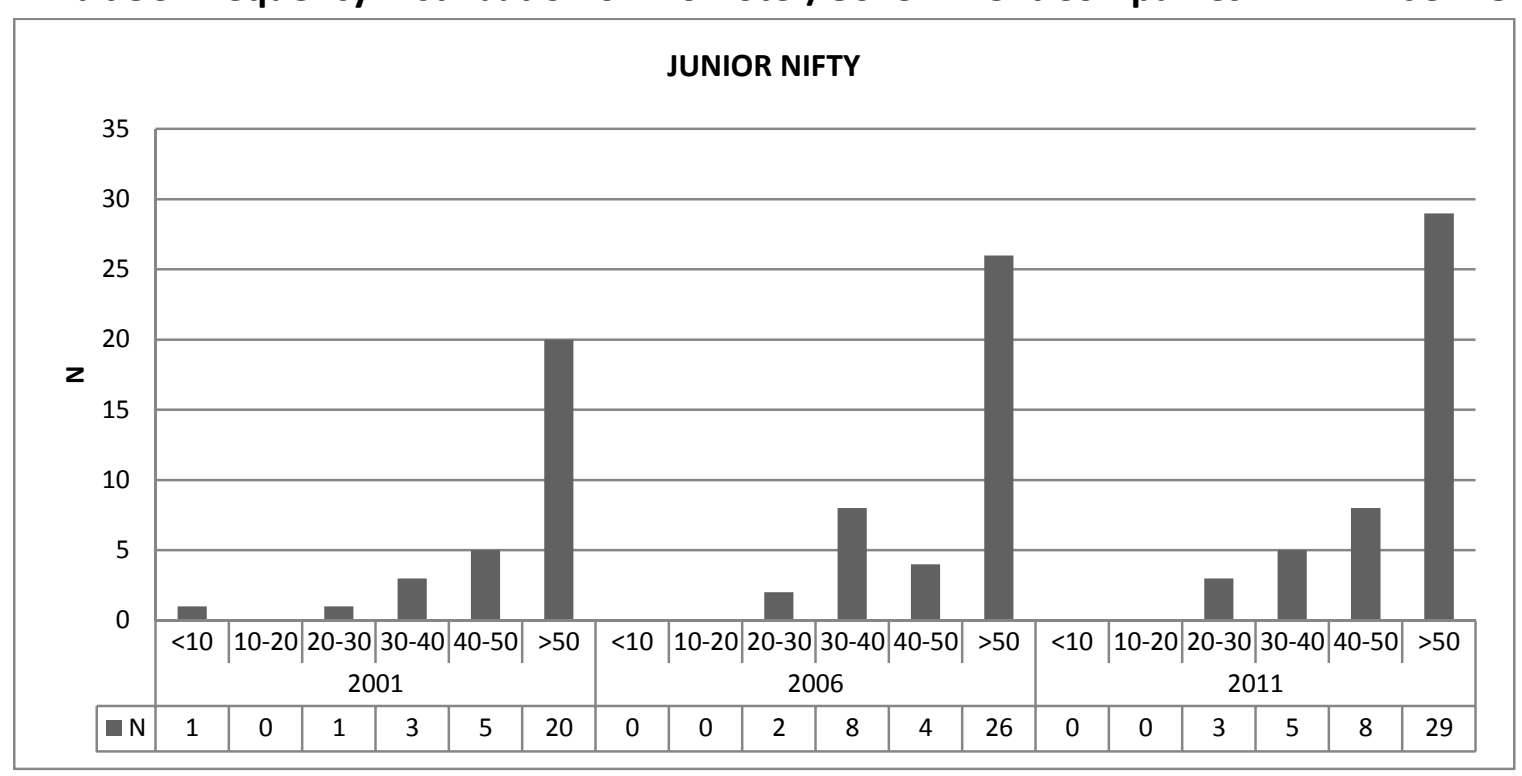

- As in the case of Set $\mathrm{A}$, the number of companies having more than $50 \%$ promoter shareholding has increased in the period 2001-2011. While the increase is not as dramatic as Set A, since not all promoter companies listed in 2011 were listed in 2001 , these graphs indicate once again that not only have promoters been increasing their stakes but also that promoter led companies gave begun to dominate the indices.

\section{In Summary}

Concentrated ownership and control is the predominant shareholding pattern in India. Over the eleven-year study period from 2001 to 2011 December, controlling shareholders have further entrenched themselves by substantially increasing their holdings, especially in the Nifty domestic companies(from $26.41 \%$ in 2001 to $46.80 \%$ in 2011) while strengthening their already large holdings in the Junior Nifty domestic companies(from 42.51\% in 2001 to $45.98 \%$ in 2011). 
In line with the trends in other developed markets, non-institutional retail shareholdings are on the wane in the country. During the study period, they declined substantially from 28.71\% in 2001 to $15.95 \%$ in 2011. In the Nifty companies, much of these holdings were picked up by the promoters in the domestic private sector companies to boost their entrenchment and as a defense against hostile takeovers. In the Junior Nifty companies where promoters already had entrenched themselves, institutional shareholders absorbed most of the holdings released by non-institutional shareholders.

Foreign companies in this study have strengthened their entrenchment with median holdings running over $50 \%$ right through. Government policy changes opening up several business sectors for majority foreign direct investment may be a contributing factor for the decline in the number of listed companies.

Government companies in this sample witnessed a decline in non-institutional share holdings over the study period, with institutional holdings showing corresponding increases. In case of management controlled companies in this sample, institutional investors have increased their holdings from 35.22\% in 2001 to $51.09 \%$ in 2011, at the expense of noninstitutional shareholdings that correspondingly went down from $40.31 \%$ in 2001 to $36.26 \%$ in 2011. Management controlled companies in the Junior Nifty group saw extraordinary escalations in institutional holdings from $7.95 \%$ in 2001 to $42.42 \%$ in 2011.

Overall, institutional investors have increased their holdings (from 25.69\% in 2001 to $29.49 \%$ in 2011), with Junior Nifty companies being the preferred target for such increases (from $18.98 \%$ in 2001 to $27.58 \%$ in 2011 ).

\section{Implications for Governance}

These trends in corporate ownership structures have several important implications for the corporations and their governance as well as for investors not in operational control. Some of the more important consequences are enumerated below: 
On the positive side, the foremost benefit is that such entrenched ownership and control will offer strategic stability and longer term sustainability, especially in case of family controlled entities; they also offer prospects of more efficient and cost-effective management, the fruits of which would largely flow down to the bottom line. There would be greater and closer managerial surveillance to preempt leakages at operational levels. Their entrepreneurial drive to grasp business opportunities as they arise and convert them to profits is rarely as effective in non-family managerial structures that usually tend to get bogged down with ritualistic bureaucracy.

On the other hand, such entrenchment and control offers immense potential to the owners/controllers for tunneling and personal enrichment at the expense of absentee shareholders. Expropriation of profits and wealth that rightly belong to absentee shareholders (as much as to those shareholders in operational control) in proportion to their shareholdings is a distinct possibility, usually manifested through abusive related party transactions, overly exorbitant executive compensation to the promoters and their kin, usurpation of corporate opportunities for personal or family advantage, and so on.

As a consequence, corporations with such ownership structures require competent, independent and trustworthy boards to protect the interests of absentee shareholders. The task, however, of installing and sustaining such effective boards for rigorous oversight and surveillance in corporations with such concentrated ownership and control is perhaps the most challenging. Populating their boards with independent directors and providing an open and transparent environment that would encourage due discharge of their duties are most likely to be influenced by the presence of such strong owners and controllers; director independence could be further compromised by excessive remuneration and offer of other perquisites and lucrative opportunities to the non-executive directors. This is a major challenge posed by such ownership structures.

Implications for management controlled companies are no less daunting, albeit for different reasons. Just because the managers are not substantial owners, the risk of their indulging in similar tunneling initiatives is no less important. Such companies' boards and directors would likely need to be even more vigilant since such structures come with the negatives of 
concentrated ownership and control structures, often without the positives that family controlled entities bring to the table.

The growing institutional investor holdings, again, can be a mixed blessing. It can help improve investee companies' governance through meaningful engagement and also use its voting clout to preempt any abusive initiatives perceived as not being in the interests of absentee shareholders. On the other hand, unscrupulous controllers may find it convenient to canvas support from the fewer institutional investors, directly or through their masters Good stewardship practices both in-house and opposite investee companies may minimize the risks of the latter

As has been noted before, some long-overdue regulatory measures are on the anvil and more of course would be required. Some key measures, among them, notably, the restraint on promoters voting on resolutions where they stand to benefit, have already been initiated through legislation and regulation; their impact will of course depend upon speedy and effective compliance monitoring.

On the flip side, regulation is only a partial deterrent and the good governance in true stewardship spirit can only come about with a wholehearted buy-in of best practices in the larger interests of the company and all its shareholders, whether controllers or absentees. 
Exhibit 9: Summary Statistics- Index Composition and Market Capitalisation

Rs. Crores

\begin{tabular}{|c|c|c|c|c|}
\hline S. No & Item & NIFTY & JUNIOR NIFTY & CNX-100 \\
\hline 1 & $\begin{array}{l}\text { Total number of Companies in the } \\
\text { Indices for one or more years } \\
\text { during2001-2011 }\end{array}$ & 86 & 103 & 189 \\
\hline 2 & $\begin{array}{l}\text { Companies Recurring Every Year in } \\
\text { the respective Indices during } 2001 \text { - } \\
2011\end{array}$ & 20 & 4 & $29^{*}$ \\
\hline 3 & Market Capitalisation-2001 & 285,000 & 28,500 & 313,500 \\
\hline 4 & $\begin{array}{l}\text { Total NSE Market } \\
\text { Capitalisation(785 listed } \\
\text { companies) }\end{array}$ & \multicolumn{3}{|c|}{552,900} \\
\hline 5 & $\begin{array}{l}\text { As a } \% \text { of NSE Market } \\
\text { Capitalisation- } 2001\end{array}$ & $51.55 \%$ & $5.15 \%$ & $56.70 \%$ \\
\hline
\end{tabular}




\begin{tabular}{|c|l|c|c|c|}
\hline 6 & $\begin{array}{l}\text { Free Float**Market Capitalisation- } \\
2011\end{array}$ & $1,405,066$ & 247,531 & $1,652,597$ \\
\hline 7 & $\begin{array}{l}\text { Total NSE Market Capitalisation- } \\
2011\end{array}$ & \multicolumn{2}{|c|}{$5,232,273$} \\
\hline 8 & $\begin{array}{l}\text { As a \% of NSE Market } \\
\text { Capitalisation (1657 listed } \\
\text { companies) }\end{array}$ & $26.85 \%$ & $4.73 \%$ & $31.58 \%$ \\
\hline
\end{tabular}

*This is larger than the sum of Nifty and Junior Nifty because it would include companies which were in one or the other of those Indices for part of the study period but together in all the years in the CNX 100; **Free float methodology adopted since 2009

Exhibit 10: Summary Statistics- Ownership Data

\begin{tabular}{|c|c|c|c|c|c|c|c|}
\hline & & \multicolumn{2}{|c|}{ NIFTY } & \multicolumn{2}{|c|}{ JUNIOR NIFTY } & \multicolumn{2}{|c|}{ CNX-100 } \\
\hline S. No & Statistic/Year & 2001 & 2011 & 2001 & 2011 & 2001 & 2011 \\
\hline \multicolumn{8}{|c|}{ Set A-Promoter Companies Only } \\
\hline 1 & Mean Promoter Ownership & 37.61 & 49.57 & 47.58 & 47.26 & 42.85 & 48.40 \\
\hline 2 & Median Promoter Ownership & 35.38 & 49.87 & 50.94 & 47.65 & 42.20 & 48.51 \\
\hline 3 & Mean Institutional Ownership & 29.88 & 27.46 & 16.86 & 29.35 & 23.37 & 28.44 \\
\hline 4 & Median Institutional Ownership & 29.07 & 27.81 & 16.04 & 26.95 & 22.95 & 27.09 \\
\hline 5 & Mean Government Ownership & 43.06 & 70.13 & 41.13 & 63.94 & 42.48 & 66.75 \\
\hline 6 & Median Government Ownership & 56.25 & 68.57 & 57.17 & 65.50 & 56.71 & 65.87 \\
\hline 7 & Mean Non-Institutional Ownership & 29.26 & 15.87 & 34.38 & 16.30 & 31.82 & 16.09 \\
\hline 8 & Median Non-Institutional Ownership & 26.21 & 14.45 & 30.98 & 15.81 & 28.46 & 14.89 \\
\hline \multicolumn{8}{|c|}{ Set A- All Companies } \\
\hline 9 & Set A-Mean Promoter Ownership & 29.49 & 39.66 & 41.29 & 38.98 & 35.51 & 36.69 \\
\hline 10 & Set A-Median Promoter Ownership & 28.59 & 46.24 & 45.12 & 42.06 & 35.77 & 41.69 \\
\hline 11 & Set A-Mean Institutional Ownership & 31.83 & 32.47 & 18.38 & 30.81 & 25.17 & 31.64 \\
\hline 12 & Set A-Median Institutional Ownership & 30.15 & 30.31 & 16.57 & 27.58 & 24.75 & 29.50 \\
\hline 13 & Set A-Mean Government Ownership & 43.06 & 70.13 & 41.13 & 63.94 & 42.48 & 66.75 \\
\hline 14 & Set A-Median Government Ownership & 56.25 & 68.57 & 57.17 & 65.50 & 56.71 & 65.87 \\
\hline 15 & Set A-Mean Non-Institutional Ownership & 31.15 & 18.38 & 34.66 & 17.94 & 32.89 & 18.16 \\
\hline 16 & Set A-Median Non-Institutional & 28.82 & 16.15 & 31.21 & 15.88 & 30.29 & 15.96 \\
\hline
\end{tabular}




\begin{tabular}{|c|c|c|c|c|c|c|c|}
\hline & & \multicolumn{2}{|c|}{ NIFTY } & \multicolumn{2}{|c|}{ JUNIOR NIFTY } & \multicolumn{2}{|c|}{ CNX-100 } \\
\hline S. No & Statistic/Year & 2001 & 2011 & 2001 & 2011 & 2001 & 2011 \\
\hline \multicolumn{8}{|c|}{ Set B-Promoter Companies Only } \\
\hline 17 & Mean Promoter Ownership & 37.55 & 49.57 & 44.99 & 47.26 & 41.27 & 48.40 \\
\hline 18 & Median Promoter Ownership & 32.08 & 49.86 & 48.83 & 47.65 & 40.62 & 48.51 \\
\hline 19 & Mean Institutional Ownership & 27.48 & 27.46 & 20.44 & 29.35 & 23.84 & 28.44 \\
\hline 20 & Median Institutional Ownership & 28.95 & 27.81 & 21.89 & 26.96 & 25.61 & 27.10 \\
\hline 21 & Mean Government Ownership & 61.87 & 70.13 & 59.30 & 63.94 & 60.40 & 66.75 \\
\hline 22 & Median Government Ownership & 67.53 & 68.57 & 66.44 & 65.49 & 67.01 & 65.86 \\
\hline 23 & Mean Non-Institutional Ownership & 28.44 & 15.86 & 27.51 & 16.30 & 27.96 & 16.09 \\
\hline 24 & Median Non-Institutional Ownership & 31.50 & 14.45 & 24.75 & 15.81 & 26.04 & 14.89 \\
\hline \multicolumn{8}{|c|}{ Set B-All Companies } \\
\hline 25 & Set B-Mean Promoter Ownership & 27.94 & 34.65 & 37.32 & 38.98 & 32.22 & 36.69 \\
\hline 26 & Set B-Median Promoter Ownership & 25.99 & 38.19 & 42.41 & 42.06 & 30.53 & 41.69 \\
\hline 27 & Set B-Mean Institutional Ownership & 29.61 & 32.47 & 20.51 & 30.81 & 25.12 & 31.64 \\
\hline 28 & Set B-Median Institutional Ownership & 31.01 & 30.31 & 18.98 & 27.58 & 25.69 & 29.49 \\
\hline 29 & Set B-Mean Government Ownership & 61.87 & 70.13 & 59.30 & 63.94 & 60.40 & 66.75 \\
\hline 30 & Set B-Median Government Ownership & 67.53 & 68.57 & 66.44 & 65.49 & 67.01 & 65.86 \\
\hline 31 & Set B-Mean Non-Institutional Ownership & 30.15 & 18.38 & 29.90 & 17.94 & 30.03 & 18.16 \\
\hline 32 & Set B-Median Non-Institutional & 32.25 & 16.14 & 25.58 & 15.88 & 28.71 & 15.95 \\
\hline
\end{tabular}




\section{References}

Aguilera, R., Kabbach de Castro, L., Lee, J., You, J. (2011), “Corporate Governance in Emerging Markets", In G. Morgan and R. Whitley (Ed.), Capitalisms and Capitalism in the 21st Century. Oxford: Oxford University Press.

Association of British Insurers-Deminor Rating, Application of the one share-one vote principle in Europe, (2005), http://va.issproxy.com/resourcecenter/publications/European_General_Reports/ABI_DEMI NOR_full\%20report.pdf

Bainbridge, Stephen M (2002),Director Primacy: The Means and Ends of corporate Governance, University of California School of Law, Research Paper no. 02-06

Bainbridge, Stephen M (2005),Director Primacy and Shareholder Disempowerment, University of California, Los Angeles School of Law, Law \& Economics Research Paper no. 05-25

Balasubramanian, N (2013),Strengthening Corporate Governance in India - A Review of Legislative and Regulatory Initiatives in 2013, Indian Institute of Management Ahmedabad Working Paper, Indian Institute of Management Bangalore - Centre for Corporate Governance and Stewardship, Working Paper (Forthcoming)

Balasubramanian, N, Samir Kumar Barua and D Karthik (2013), Corporate Governance Issues in Executive Compensation - The Indian Experience: 2008 - 2012, Research Paper, National Stock Exchange of India, Mumbai; Indian Institute of Management Bangalore - Centre for Corporate Governance and Citizenship, Bangalore; Indian Institute of Management Ahmedabad [Forthcoming]

Balasubramanian, N. (2010), Corporate Governance and Stewardship: Emerging Role and Responsibilities of Corporate Boards and Directors, Tata McGraw Hill, New Delhi

Baysinger, B. D., Kosnik, R. D., \& Turk, T. A. (1991).“Effects of Board and Ownership Structure on Corporate R\&D Strategy", Academy Of Management Journal, 34(1), 205-214

Bebchuk, L. A. and Fried.M.Jesse, (2002) "Managerial Power and Rent Extraction in the Design of Executive Compensation", Working Paper No: 10742, National Bureau of Economic Research

Bebchuk, Lucian A (2005), The Case for Increasing Shareholder Power, Harvard Law Review, vol. 118, pp. 833-917 
Bebchuk, Lucian A (2006), Letting Shareholders Set the Rules, Harvard Law Review, vol. 119, pp. 1784-181

Berle, Adolph A (1931), Corporate Powers as Powers in Trust, Harvard Law Review, Vol 44, No. 7, pp. 1049-1074

Berle, Adolph and Gardiner Means, (1932), The Modern Corporation and Private Property, the 1967 revision, Harcourt, Brace \& World, Inc, New York

David, P., Kochhar, R., \& Levitas, E. (1998). "Research Notes- The Effect of Institutional Investors on the Level and Mix of CEO Compensation", Academy Of Management Journal, 41(2), 200-208

Dodd, E. Merrick (1932), For Whom Are Corporate Managers Trustees? , Harvard Law Review. Vol 45, No. 7, pp. 1145, 1163

Dunlavy, C.A, (2006), Social Conceptions of the Corporation: Insights from the History of Shareholder Voting Rights, 63 Wash. \& Lee L. Rev. 1347,http://scholarlycommons.law.wlu.edu/wlulr/vol63/iss4/4

Goodstein, J., \&Boeker, W. (1991).Turbulence at the Top: A New Perspective on Governance Structure Changes and Strategic Change. Academy Of Management Journal, 34(2), 306-330

La Porta, R., Lopez-de-Silanes, F., \&Shleifer, A. (1999). “Corporate Ownership Around the World", Journal Of Finance, 54(2), 471-517

Marianne, B., Mehta, P., \&Mullainathan, S. (2002). "Ferreting Out Tunneling: An Application To Indian Business Groups," The Quarterly Journal of Economics, MIT Press, vol. 117(1), pages $121-148$

McDonald, H. (1999), "The Polyester Prince, The Rise of DhirubhaiAmbani" (1st ed.), St Leonards, NSW, Allen and Unwin

Morck, R. and Yeung, B. (2003), "Agency Problems in Large Family Business Groups", Entrepreneurship Theory and Practice, 27: 367-382

OECD (2012) Related Party Transactions and Minority Shareholder Rights, OECD Publishing.

Roe, Mark J., (2004), "The Institutions of Corporate Governance", Discussion Paper Series. Paper 488, Harvard Law School John M. Olin Center for Law, Economics and Business

Stout, Lynn A (2002), Bad And Not So Bad Arguments for Shareholder Primacy, Southern California Law Review, Vol75, pp. 1189 - 1209 
Stout, Lynn A (2012), New Thinking on Shareholder Primacy, Accounting, Economics, and Law: A Convivium, Vol2, Issue 2, Pages 1-23, ISSN (Online) 2152- 2820,

Strine Jr.,Leo E (2006),Towards a True Corporate Republic: A Traditionalist Response to Lucian's Solution for Improving Corporate America, Harvard Law and Economics Discussion Paper, No 541

Wright, P., Ferris, S. P., Sarin, A., \&Awasthi, V. (1996), "Impact of Corporate Insider, Blockholder, and Institutional Equity Ownership On Firm Risk Taking", Academy Of Management Journal, 39(2), 441-463 
Table of Contents for Annexures

\begin{tabular}{|c|c|c|}
\hline S.No & Exhibit Name & $\begin{array}{l}\text { Page } \\
\text { No }\end{array}$ \\
\hline 1 & Exhibit AN-1 NIFTY -Set A-Mean Ownership Trends, 2001-2011 & 42 \\
\hline 2 & Exhibit AN-2 NIFTY-Set A-Median Ownership Trends, 2001-2011 & 42 \\
\hline 3 & $\begin{array}{l}\text { Exhibit AN-3 NIFTY-Set A-Domestic Pvt Sector Companies-Mean Ownership } \\
\text { Trends, 2001-2011 }\end{array}$ & 43 \\
\hline 4 & $\begin{array}{l}\text { Exhibit AN-4 NIFTY-Set A-Domestic Pvt Sector Companies-Median } \\
\text { Ownership Trends, 2001-2011 }\end{array}$ & 43 \\
\hline 5 & $\begin{array}{l}\text { Exhibit AN-5 NIFTY-Set A-Foreign Pvt Sector Companies-Mean Ownership } \\
\text { Trends, 2001-2011 }\end{array}$ & 44 \\
\hline 6 & $\begin{array}{l}\text { Exhibit AN-6 NIFTY-Set A-Foreign Pvt Sector Companies-Median Ownership } \\
\text { Trends, 2001-2011 }\end{array}$ & 44 \\
\hline 7 & $\begin{array}{l}\text { Exhibit AN-7 NIFTY-Set A-Government Owned Companies-Mean Ownership } \\
\text { Trends, 2001-2011 }\end{array}$ & 45 \\
\hline 8 & $\begin{array}{l}\text { Exhibit AN-8 NIFTY-Set A-Government Owned Companies-Median } \\
\text { Ownership Trends, 2001-2011 }\end{array}$ & 45 \\
\hline 9 & $\begin{array}{l}\text { Exhibit AN-9 NIFTY-Set A-Management Controlled Companies-Mean } \\
\text { Ownership Trends, 2001-2011 }\end{array}$ & 46 \\
\hline 10 & $\begin{array}{l}\text { Exhibit AN-10 NIFTY-Set A-Management Controlled Companies-Median } \\
\text { Ownership Trends, 2001-2011 }\end{array}$ & 46 \\
\hline 11 & $\begin{array}{l}\text { Exhibit AN-11 NIFTY-Set A-Mean Institutional Ownership Trends, 2001- } \\
2011\end{array}$ & 47 \\
\hline 12 & $\begin{array}{l}\text { Exhibit AN-12 NIFTY-Set A-Median Institutional Ownership Trends, 2001- } \\
2011\end{array}$ & 47 \\
\hline 13 & $\begin{array}{l}\text { Exhibit AN-13 NIFTY-Set A-Mean Non Institutional Ownership Trends, } \\
\text { 2001-2011 }\end{array}$ & 48 \\
\hline 14 & $\begin{array}{l}\text { Exhibit AN-14 NIFTY-Set A-Median Non Institutional Ownership Trends, } \\
\text { 2001-2011 }\end{array}$ & 48 \\
\hline 15 & Exhibit AS-1 SIFTY-Set A-Mean Ownership Trends, 2001-2011 & 49 \\
\hline 16 & Exhibit AS-2 SIFTY-Set A-Median Ownership Trends, 2001-2011 & 49 \\
\hline 17 & $\begin{array}{l}\text { Exhibit AS-3 SIFTY-Set A-Domestic Pvt Sector Companies-Mean Ownership } \\
\text { Trends, 2001-2011 }\end{array}$ & 50 \\
\hline 18 & $\begin{array}{l}\text { Exhibit AS-4 SIFTY-Set A-Domestic Pvt Sector Companies-Median } \\
\text { Ownership Trends, 2001-2011 }\end{array}$ & 50 \\
\hline 19 & $\begin{array}{l}\text { Exhibit AS-5 SIFTY-Set A-Foreign Pvt Sector Companies-Mean Ownership } \\
\text { Trends, 2001-2011 }\end{array}$ & 51 \\
\hline 20 & $\begin{array}{l}\text { Exhibit AS-6 SIFTY-Set A-Foreign Pvt Sector Companies-Median Ownership } \\
\text { Trends, 2001-2011 }\end{array}$ & 51 \\
\hline
\end{tabular}




\begin{tabular}{|c|c|c|}
\hline 21 & $\begin{array}{l}\text { Exhibit AS-7 SIFTY-Set A-Government Owned Companies-Mean Ownership } \\
\text { Trends, 2001-2011 }\end{array}$ & 52 \\
\hline 22 & $\begin{array}{l}\text { Exhibit AS-8 SIFTY-Set A-Government Owned Companies-Median } \\
\text { Ownership Trends, 2001-2011 }\end{array}$ & 52 \\
\hline 23 & $\begin{array}{l}\text { Exhibit AS-9 SIFTY-Set A-Management Controlled Companies-Mean } \\
\text { Ownership Trends, 2001-2011 }\end{array}$ & 53 \\
\hline 24 & $\begin{array}{l}\text { Exhibit AS-10 SIFTY-Set A-Management Controlled Companies-Median } \\
\text { Ownership Trends, 2001-2011 }\end{array}$ & 53 \\
\hline 25 & Exhibit AS-11 SIFTY-Set A-Mean Institutional Ownership Trends, 2001-2011 & 54 \\
\hline 26 & $\begin{array}{l}\text { Exhibit AS-12 SIFTY-Set A-Median Institutional Ownership Trends, 2001- } \\
2011\end{array}$ & 54 \\
\hline 27 & $\begin{array}{l}\text { Exhibit AS-13 SIFTY-Set A-Mean Non Institutional Ownership Trends, 2001- } \\
2011\end{array}$ & 55 \\
\hline 28 & $\begin{array}{l}\text { Exhibit AS-14 SIFTY-Set A-Median Non Institutional Ownership Trends, } \\
\text { 2001-2011 }\end{array}$ & 55 \\
\hline 29 & Exhibit AC-1 CNX-100-Set A-Mean Ownership Trends, 2001-2011 & 56 \\
\hline 30 & Exhibit AC-2 CNX-100-Set A-Median Ownership Trends, 2001-2011 & 56 \\
\hline 31 & $\begin{array}{l}\text { Exhibit AC-3 CNX-100-Set A-Domestic Pvt Sector Companies-Mean } \\
\text { Ownership Trends, 2001-2011 }\end{array}$ & 57 \\
\hline 32 & $\begin{array}{l}\text { Exhibit AC-4 CNX-100-Set A-Domestic Pvt Sector Companies-Median } \\
\text { Ownership Trends, 2001-2011 }\end{array}$ & 57 \\
\hline 33 & $\begin{array}{l}\text { Exhibit AC-5 CNX-100-Set A-Foreign Pvt Sector Companies-Mean } \\
\text { Ownership Trends, 2001-2011 }\end{array}$ & 58 \\
\hline 34 & $\begin{array}{l}\text { Exhibit AC-6 CNX-100-Set A-Foreign Pvt Sector Companies-Median } \\
\text { Ownership Trends, 2001-2011 }\end{array}$ & 58 \\
\hline 35 & $\begin{array}{l}\text { Exhibit AC-7 CNX-100-Set A-Government Owned Companies-Mean } \\
\text { Ownership Trends, 2001-2011 }\end{array}$ & 59 \\
\hline 36 & $\begin{array}{l}\text { Exhibit AC-8 CNX-100-Set A-Government Owned Companies-Median } \\
\text { Ownership Trends, 2001-2011 }\end{array}$ & 59 \\
\hline 37 & $\begin{array}{l}\text { Exhibit AC-9 CNX-100-Set A-Management Controlled Companies-Mean } \\
\text { Ownership Trends, 2001-2011 }\end{array}$ & 60 \\
\hline 38 & $\begin{array}{l}\text { Exhibit AC-10 CNX-100-Set A-Management Controlled Companies-Median } \\
\text { Ownership Trends, 2001-2011 }\end{array}$ & 60 \\
\hline 39 & $\begin{array}{l}\text { Exhibit AC-11 CNX-100-Set A-Mean Institutional Ownership Trends, 2001- } \\
2011\end{array}$ & 61 \\
\hline 40 & $\begin{array}{l}\text { Exhibit AC-12 CNX-100-Set A-Median Institutional Ownership Trends, 2001- } \\
2011\end{array}$ & 61 \\
\hline 41 & $\begin{array}{l}\text { Exhibit AC-13 CNX-100-Set A-Mean Non Institutional Ownership Trends, } \\
\text { 2001-2011 }\end{array}$ & 62 \\
\hline 42 & $\begin{array}{l}\text { Exhibit AC-14 CNX-100-Set A-Median Non Institutional Ownership Trends, } \\
\text { 2001-2011 }\end{array}$ & 62 \\
\hline 43 & Exhibit BN-1 NIFTY-Set B-Mean Ownership Trends, 2001-2011 & 63 \\
\hline
\end{tabular}




\begin{tabular}{|c|c|c|}
\hline 44 & Exhibit BN-2 NIFTY-Set B-Median Ownership Trends, 2001-2011 & 63 \\
\hline 45 & $\begin{array}{l}\text { Exhibit BN-3 NIFTY-Set B-Domestic Pvt Sector Companies-Mean Ownership } \\
\text { Trends, 2001-2011 }\end{array}$ & 64 \\
\hline 46 & $\begin{array}{l}\text { Exhibit BN-4 NIFTY-Set B-Domestic Pvt Sector Companies-Median } \\
\text { Ownership Trends, 2001-2011 }\end{array}$ & 64 \\
\hline 47 & $\begin{array}{l}\text { Exhibit BN-5 NIFTY-Set B-Foreign Pvt Sector Companies-Mean Ownership } \\
\text { Trends, 2001-2011 }\end{array}$ & 65 \\
\hline 48 & $\begin{array}{l}\text { Exhibit BN-6 NIFTY-Set B-Foreign Pvt Sector Companies-Median Ownership } \\
\text { Trends, 2001-2011 }\end{array}$ & 65 \\
\hline 49 & $\begin{array}{l}\text { Exhibit BN-7 NIFTY-Set B-Government Owned Companies-Mean Ownership } \\
\text { Trends, 2001-2011 }\end{array}$ & 66 \\
\hline 50 & $\begin{array}{l}\text { Exhibit BN-8 NIFTY-Set B-Government Owned Companies-Median } \\
\text { Ownership Trends, 2001-2011 }\end{array}$ & 66 \\
\hline 51 & $\begin{array}{l}\text { Exhibit BN-9 NIFTY-Set B-Management Controlled Companies-Mean } \\
\text { Ownership Trends, 2001-2011 }\end{array}$ & 67 \\
\hline 52 & $\begin{array}{l}\text { Exhibit BN-10 NIFTY-Set B-Management Controlled Companies-Median } \\
\text { Ownership Trends, 2001-2011 }\end{array}$ & 67 \\
\hline 53 & $\begin{array}{l}\text { Exhibit BN-11 NIFTY-Set B-Mean Institutional Ownership Trends, 2001- } \\
2011\end{array}$ & 68 \\
\hline 54 & $\begin{array}{l}\text { Exhibit BN-12 NIFTY-Set B-Median Institutional Ownership Trends, 2001- } \\
2011\end{array}$ & 68 \\
\hline 55 & $\begin{array}{l}\text { Exhibit BN-13 NIFTY-Set B-Mean Non Institutional Ownership Trends, 2001- } \\
2011\end{array}$ & 69 \\
\hline 56 & $\begin{array}{l}\text { Exhibit BN-14 NIFTY-Set B-Median Non Institutional Ownership Trends, } \\
\text { 2001-2011 }\end{array}$ & 69 \\
\hline 57 & Exhibit BS-1 SIFTY-Set B-Mean Ownership Trends, 2001-2011 & 70 \\
\hline 58 & Exhibit BS-2 SIFTY-Set B-Median Ownership Trends, 2001-2011 & 70 \\
\hline 59 & $\begin{array}{l}\text { Exhibit BS-3 SIFTY-Set B-Domestic Pvt Sector Companies-Mean Ownership } \\
\text { Trends, 2001-2011 }\end{array}$ & 71 \\
\hline 60 & $\begin{array}{l}\text { Exhibit BS-4 SIFTY-Set B-Domestic Pvt Sector Companies-Median } \\
\text { Ownership Trends, 2001-2011 }\end{array}$ & 71 \\
\hline 61 & $\begin{array}{l}\text { Exhibit BS-5 SIFTY-Set B-Foreign Pvt Sector Companies-Mean Ownership } \\
\text { Trends, 2001-2011 }\end{array}$ & 72 \\
\hline 62 & $\begin{array}{l}\text { Exhibit BS-6 SIFTY-Set B-Foreign Pvt Sector Companies-Median Ownership } \\
\text { Trends, 2001-2011 }\end{array}$ & 72 \\
\hline 63 & $\begin{array}{l}\text { Exhibit BS-7 SIFTY-Set B-Government Owned Companies-Mean Ownership } \\
\text { Trends, 2001-2011 }\end{array}$ & 73 \\
\hline 64 & $\begin{array}{l}\text { Exhibit BS-8 SIFTY-Set B-Government Owned Companies-Median } \\
\text { Ownership Trends, 2001-2011 }\end{array}$ & 73 \\
\hline 65 & $\begin{array}{l}\text { Exhibit BS-9 SIFTY-Set B-Management Controlled Companies-Mean } \\
\text { Ownership Trends, 2001-2011 }\end{array}$ & 74 \\
\hline 66 & $\begin{array}{l}\text { Exhibit BS-10 SIFTY-Set B-Management Controlled Companies-Median } \\
\text { Ownership Trends, 2001-2011 }\end{array}$ & 74 \\
\hline
\end{tabular}




\begin{tabular}{|c|c|c|}
\hline 67 & Exhibit BS-11 SIFTY-Set B-Mean Institutional Ownership Trends, 2001-2011 & 75 \\
\hline 68 & $\begin{array}{l}\text { Exhibit BS-12 SIFTY-Set B-Median Institutional Ownership Trends, 2001- } \\
2011\end{array}$ & 75 \\
\hline 69 & $\begin{array}{l}\text { Exhibit BS-13 SIFTY-Set B-Mean Non Institutional Ownership Trends, 2001- } \\
2011\end{array}$ & 76 \\
\hline 70 & $\begin{array}{l}\text { Exhibit BS-14 SIFTY-Set B-Median Non Institutional Ownership Trends, } \\
\text { 2001-2011 }\end{array}$ & 76 \\
\hline 71 & Exhibit BC-1 CNX-100-Set B-Mean Ownership Trends, 2001-2011 & 77 \\
\hline 72 & Exhibit BC-2 CNX-100-Set B-Median Ownership Trends, 2001-2011 & 77 \\
\hline 73 & $\begin{array}{l}\text { Exhibit BC-3 CNX-100-Set B-Domestic Pvt Sector Companies-Mean } \\
\text { Ownership Trends, 2001-2011 }\end{array}$ & 78 \\
\hline 74 & $\begin{array}{l}\text { Exhibit BC-4 CNX-100-Set B-Domestic Pvt Sector Companies-Median } \\
\text { Ownership Trends, 2001-2011 }\end{array}$ & 78 \\
\hline 75 & $\begin{array}{l}\text { Exhibit BC-5 CNX-100-Set B-Foreign Pvt Sector Companies-Mean } \\
\text { Ownership Trends, 2001-2011 }\end{array}$ & 79 \\
\hline 76 & $\begin{array}{l}\text { Exhibit BC-6 CNX-100-Set B-Foreign Pvt Sector Companies-Median } \\
\text { Ownership Trends, 2001-2011 }\end{array}$ & 79 \\
\hline 77 & $\begin{array}{l}\text { Exhibit BC-7 CNX-100-Set B-Government Owned Companies-Mean } \\
\text { Ownership Trends, 2001-2011 }\end{array}$ & 80 \\
\hline 78 & $\begin{array}{l}\text { Exhibit BC-8 CNX-100-Set B-Government Owned Companies-Median } \\
\text { Ownership Trends, 2001-2011 }\end{array}$ & 80 \\
\hline 79 & $\begin{array}{l}\text { Exhibit BC-9 CNX-100-Set B-Management Controlled Companies-Mean } \\
\text { Ownership Trends, 2001-2011 }\end{array}$ & 81 \\
\hline 80 & $\begin{array}{l}\text { Exhibit BC-10 CNX-100-Set B-Management Controlled Companies-Median } \\
\text { Ownership Trends, 2001-2011 }\end{array}$ & 81 \\
\hline 81 & $\begin{array}{l}\text { Exhibit BC-11 CNX-100-Set B-Mean Institutional Ownership Trends, 2001- } \\
2011\end{array}$ & 82 \\
\hline 82 & $\begin{array}{l}\text { Exhibit BC-12 CNX-100-Set B-Median Institutional Ownership Trends, 2001- } \\
2011\end{array}$ & 82 \\
\hline 83 & $\begin{array}{l}\text { Exhibit BC-13 CNX-100-Set B-Mean Non Institutional Ownership Trends, } \\
\text { 2001-2011 }\end{array}$ & 83 \\
\hline 84 & $\begin{array}{l}\text { Exhibit BC-14 CNX-100-Set B-Median Non Institutional Ownership Trends, } \\
\text { 2001-2011 }\end{array}$ & 83 \\
\hline 85 & List of Companies that appeared in the CNX-100 & 84 \\
\hline
\end{tabular}


Exhibit AN-1 NIFTY-Set A-Mean Ownership Trends, 2001-2011

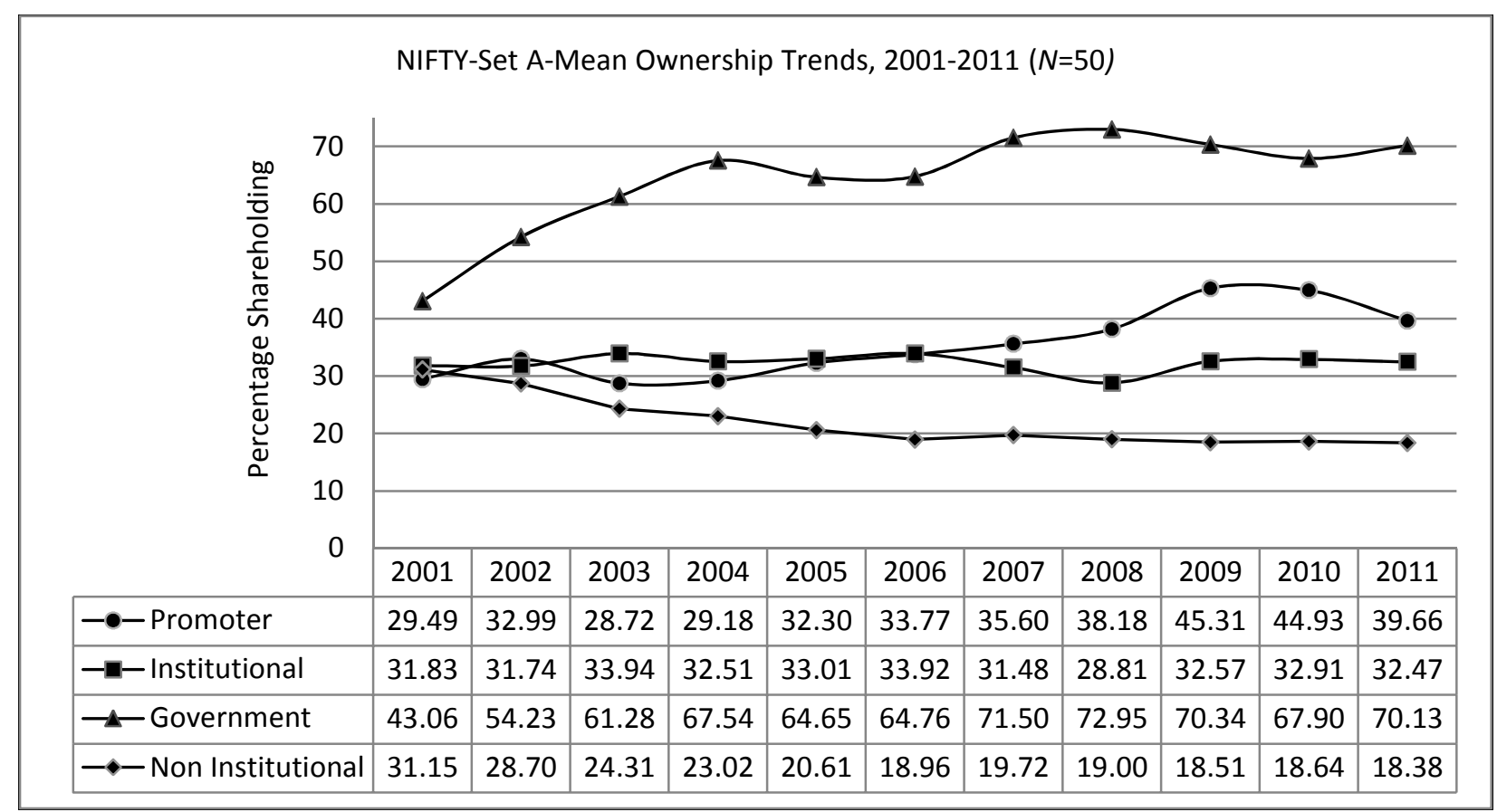

Exhibit AN-2 NIFTY-Set A-Median Ownership Trends, 2001-2011 


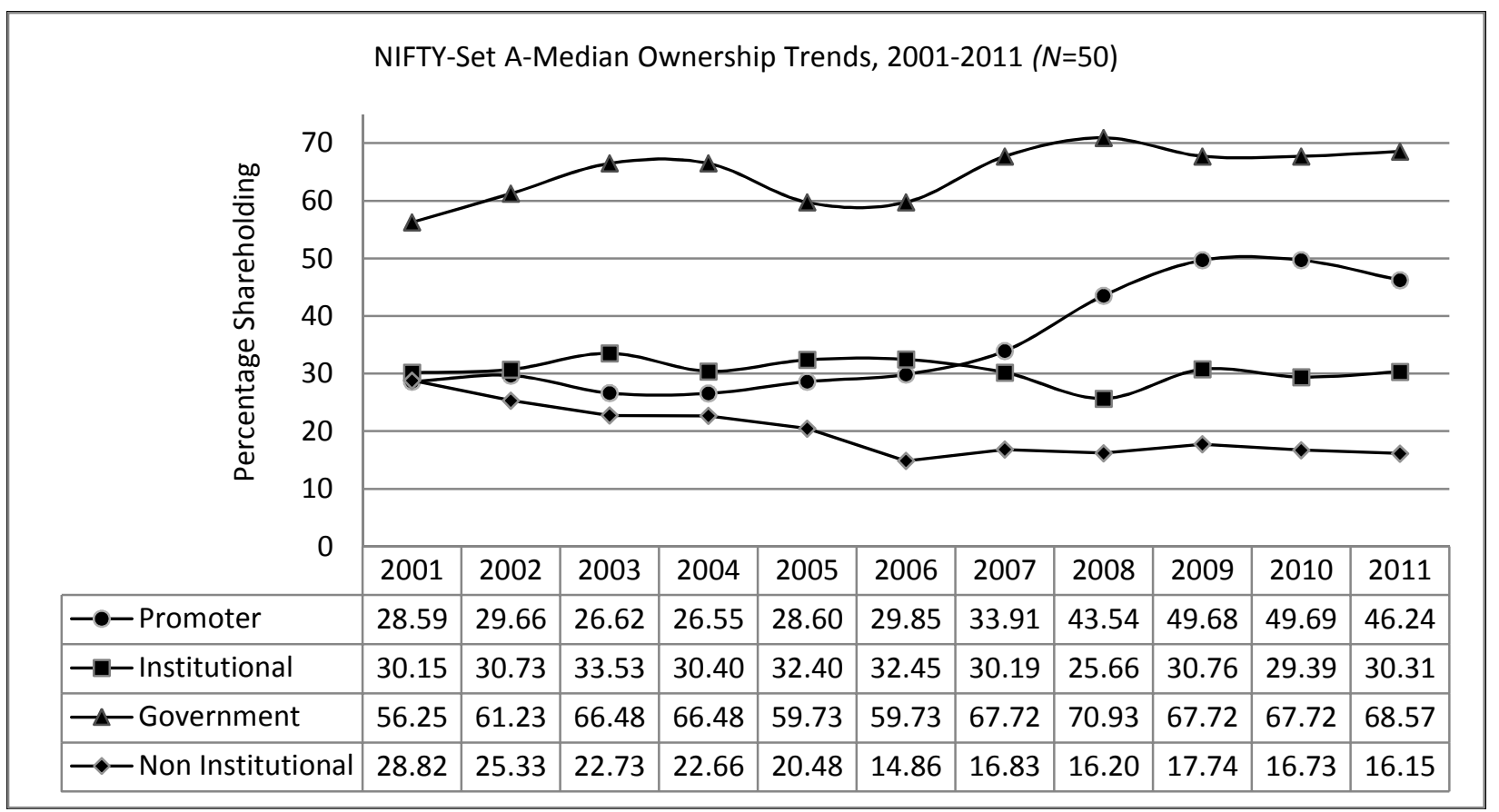

Exhibit AN-3 NIFTY-Set A-Domestic Pvt. Sector Companies-Mean Ownership Trends, 20012011

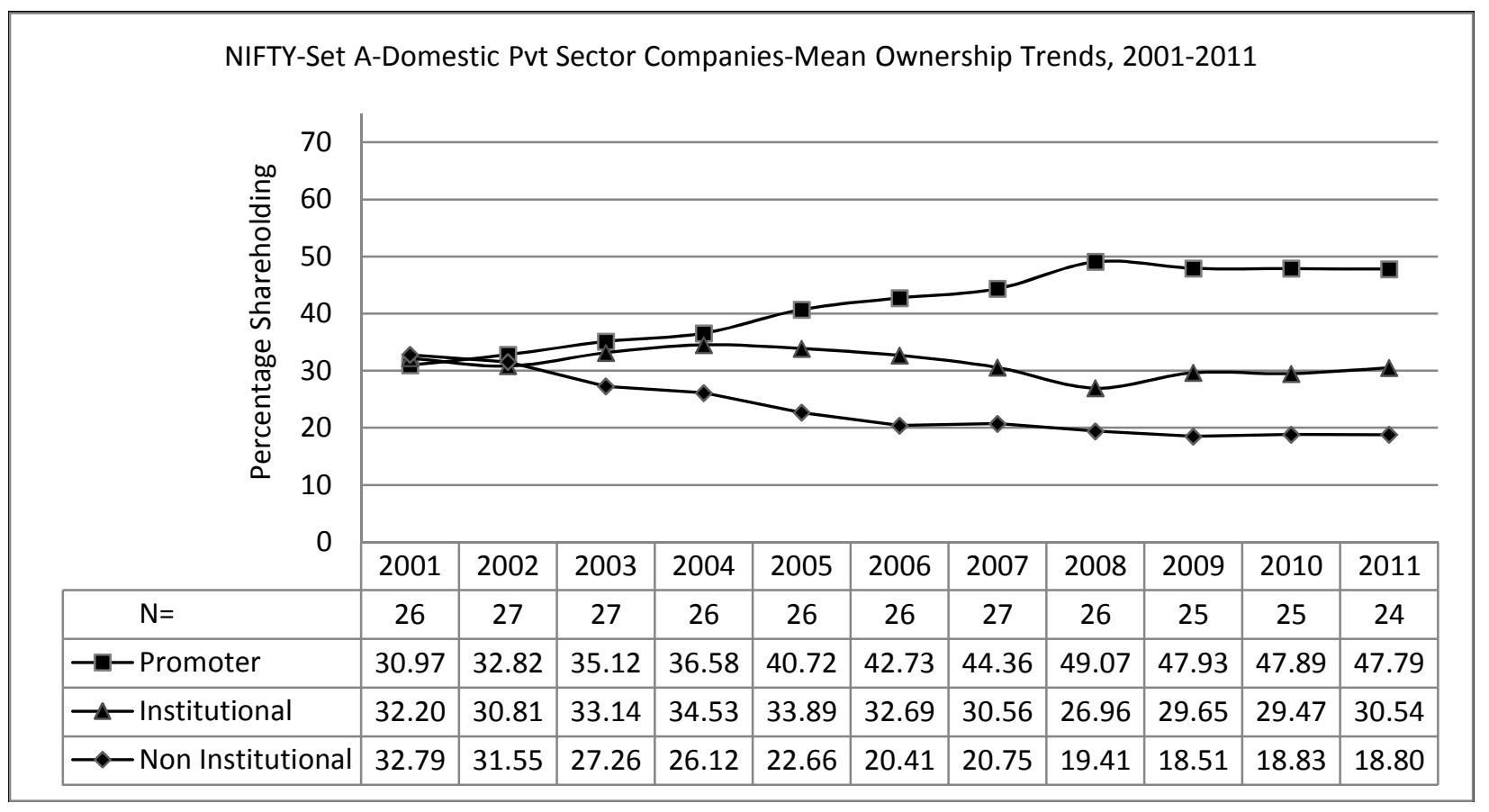


Exhibit AN-4 NIFTY-Set A-Domestic Pvt. Sector Companies-Median Ownership Trends, 20012011

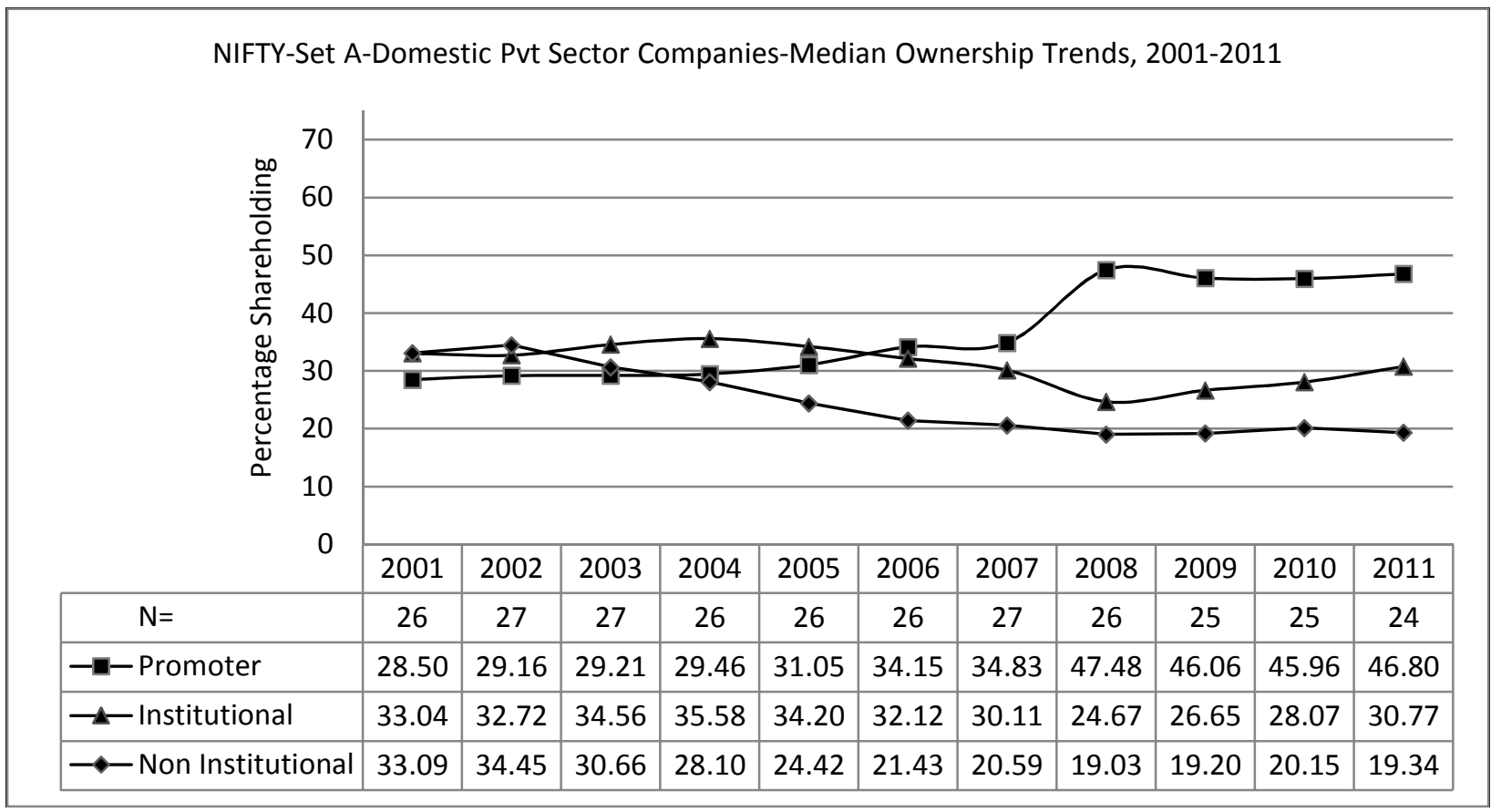

Exhibit AN-5 NIFTY-Set A-Foreign Pvt. Sector Companies-Mean Ownership Trends, 20012011

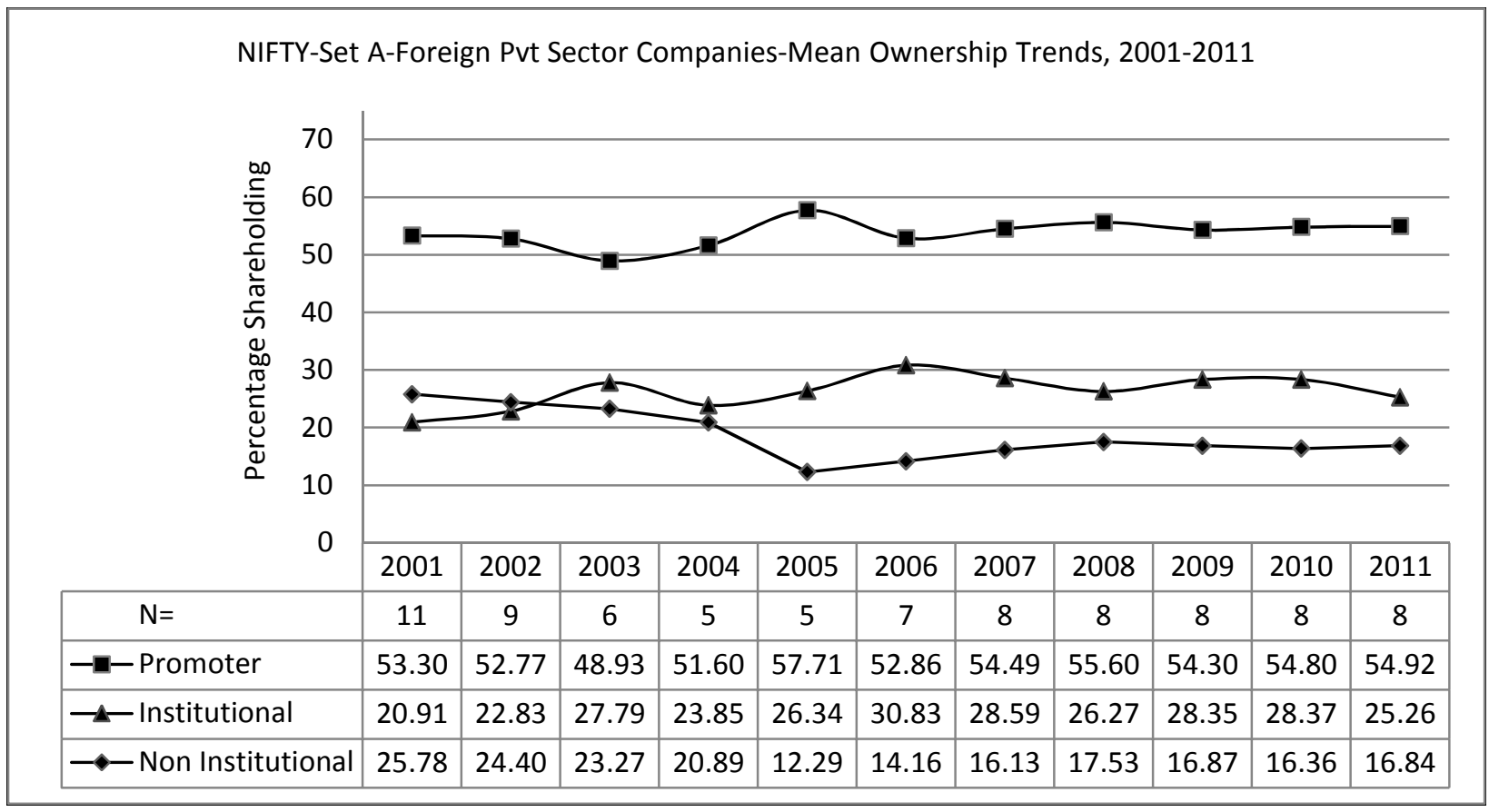


Exhibit AN-6 NIFTY-Set A-Foreign Pvt. Sector Companies-Median Ownership Trends, 20012011

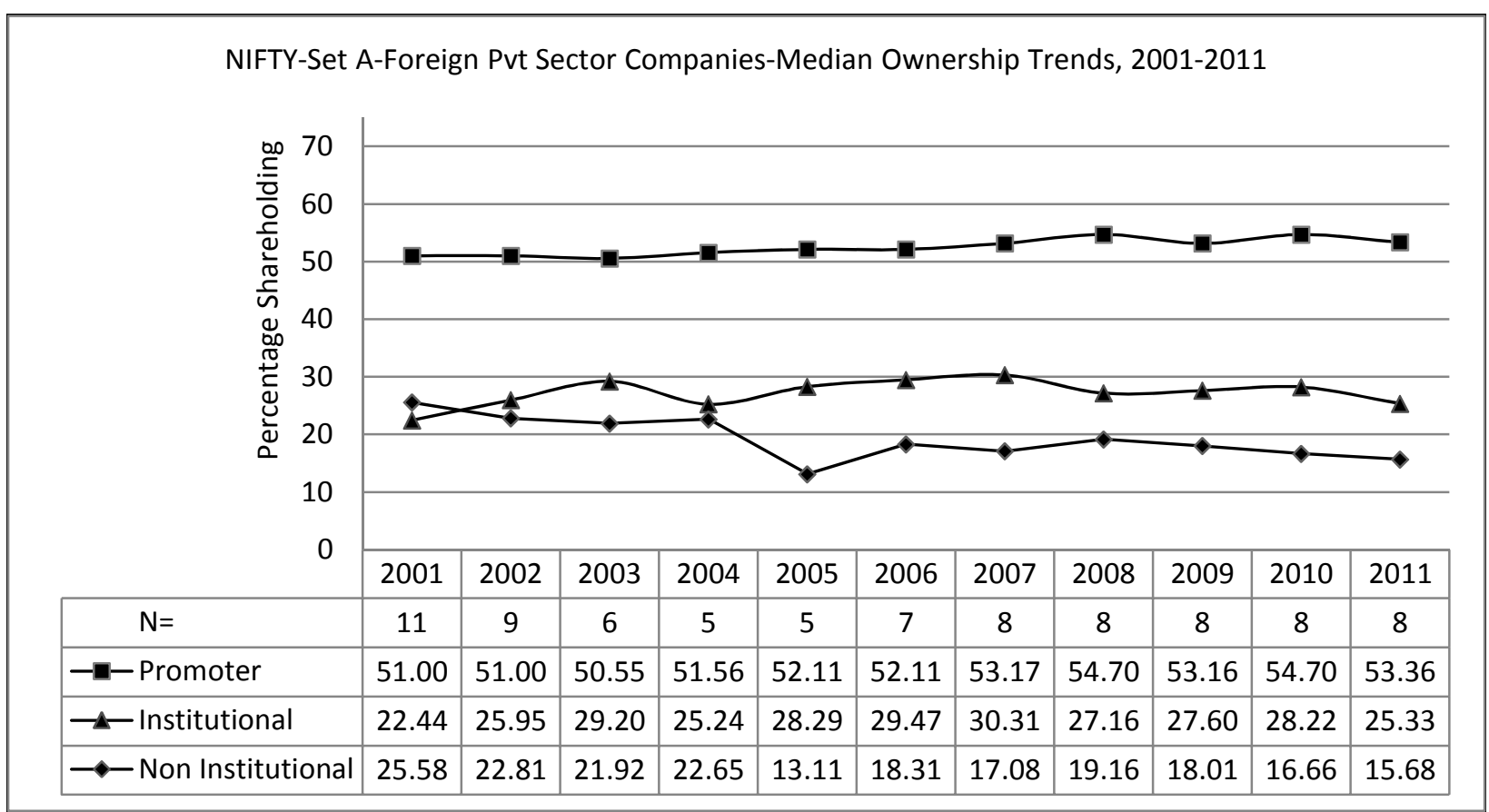

Exhibit AN-7 NIFTY-Set A-Government Owned Companies-Mean Ownership Trends, 20012011 


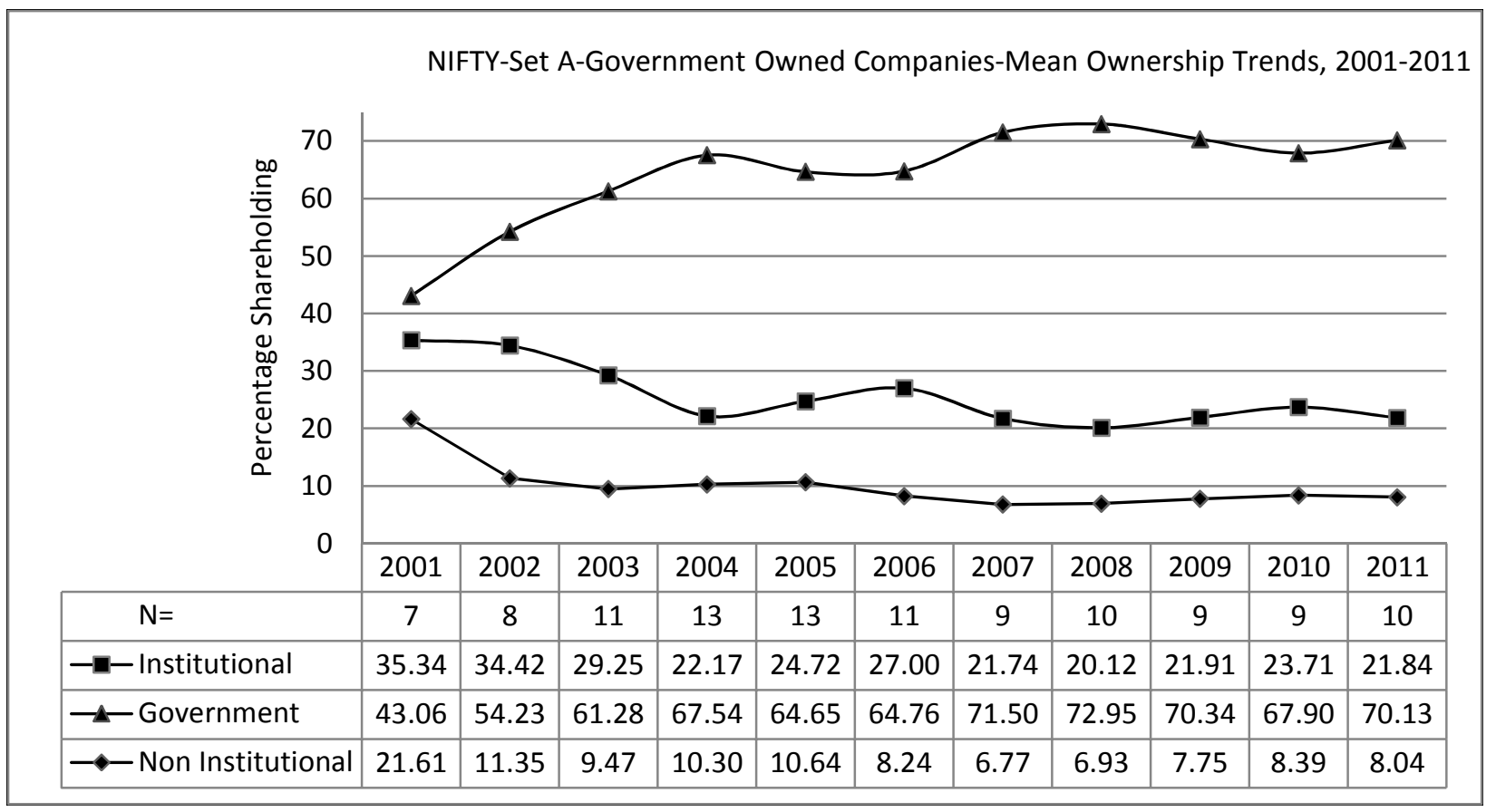

Exhibit AN-8 NIFTY-Set A-Government Owned Companies-Median Ownership Trends, 20012011

NIFTY-Set A-Government Owned Companies-Median Ownership Trends, 2001-2011

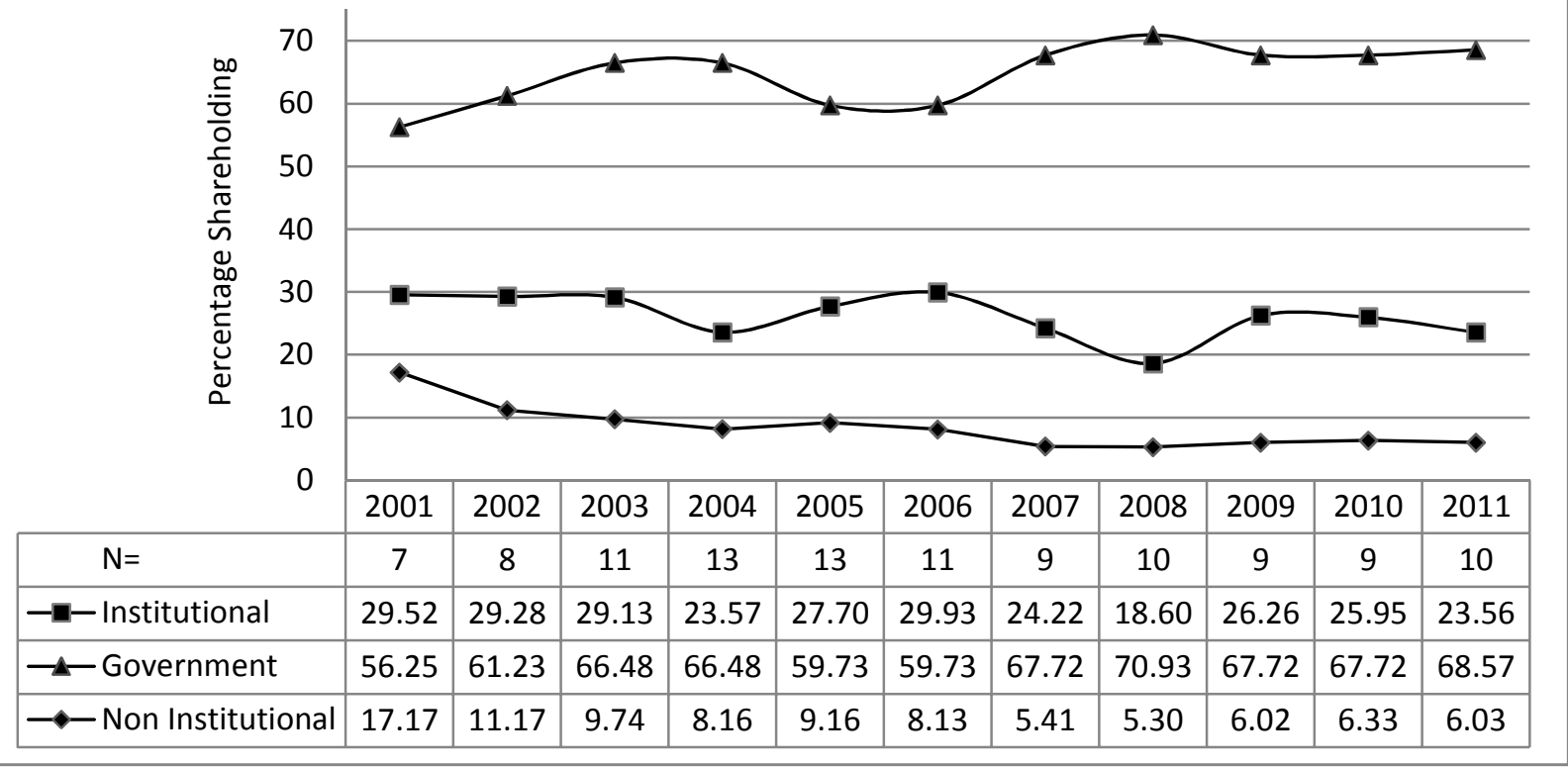


Exhibit AN-9 NIFTY-Set A-Management Controlled Companies-Mean Ownership Trends, 2001-2011

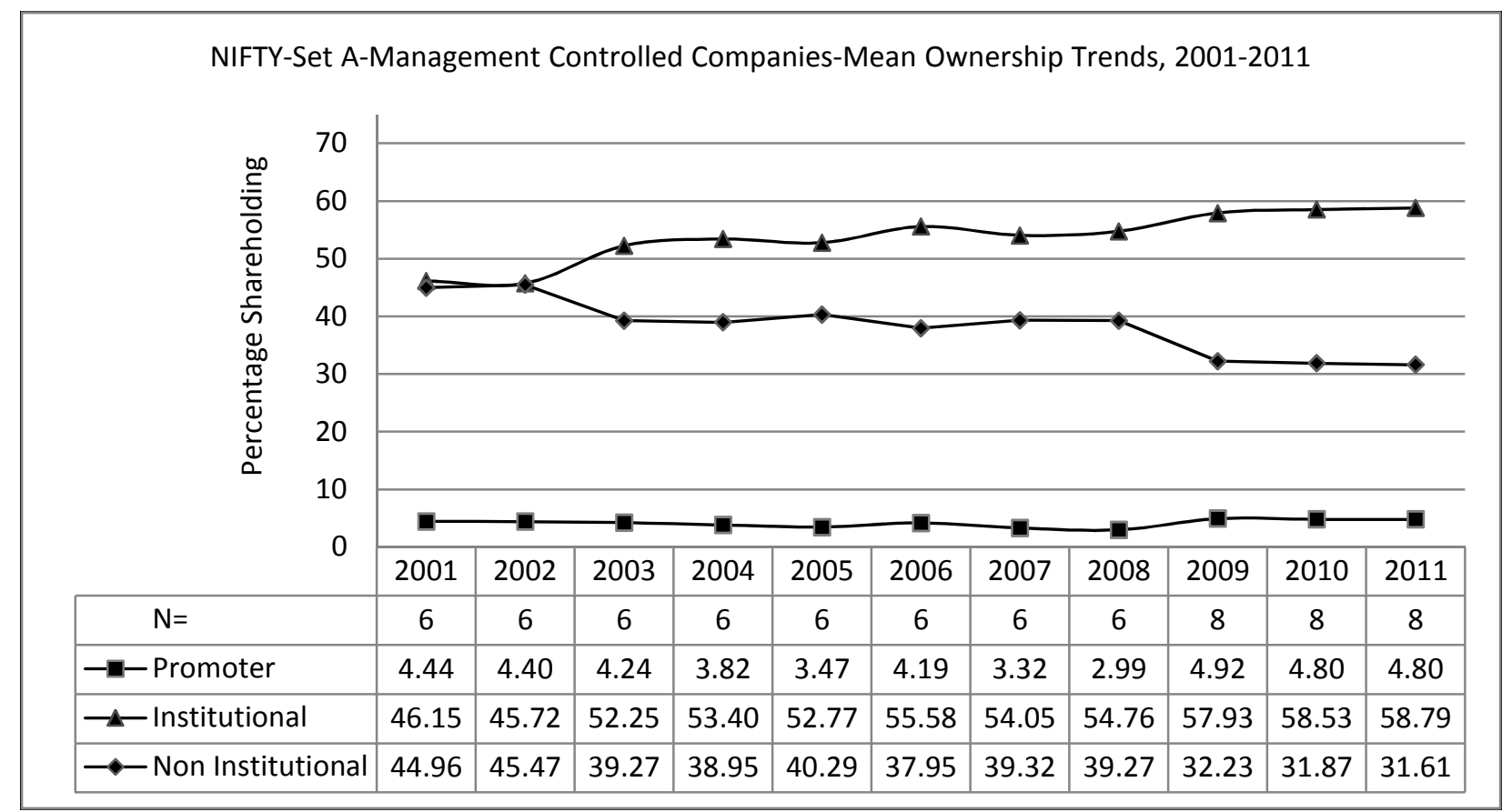

Exhibit AN-10 NIFTY-Set A-Management Controlled Companies-Median Ownership Trends, 2001-2011

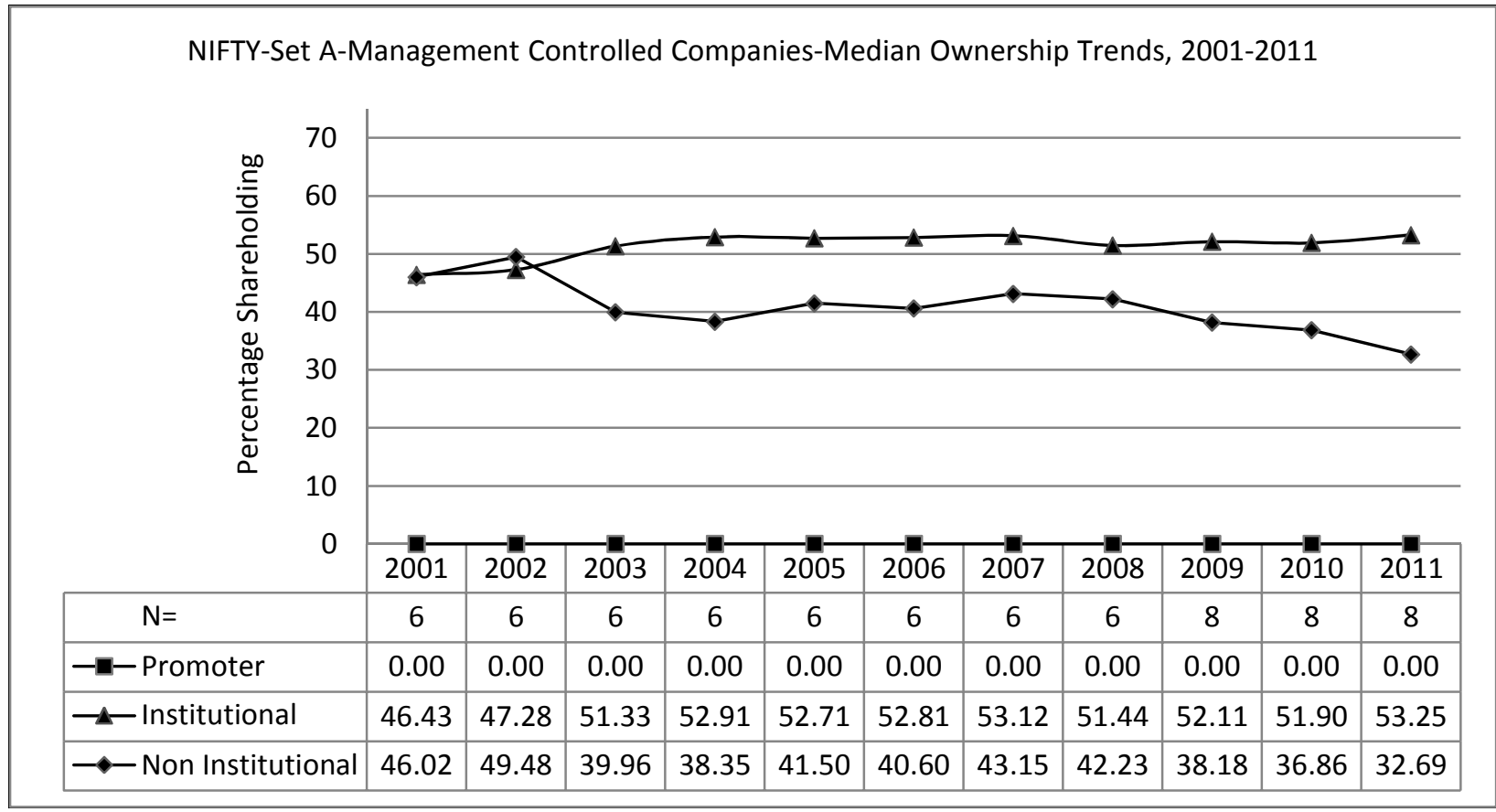


Exhibit AN-11 NIFTY-Set A-Mean Institutional Ownership Trends, 2001-2011

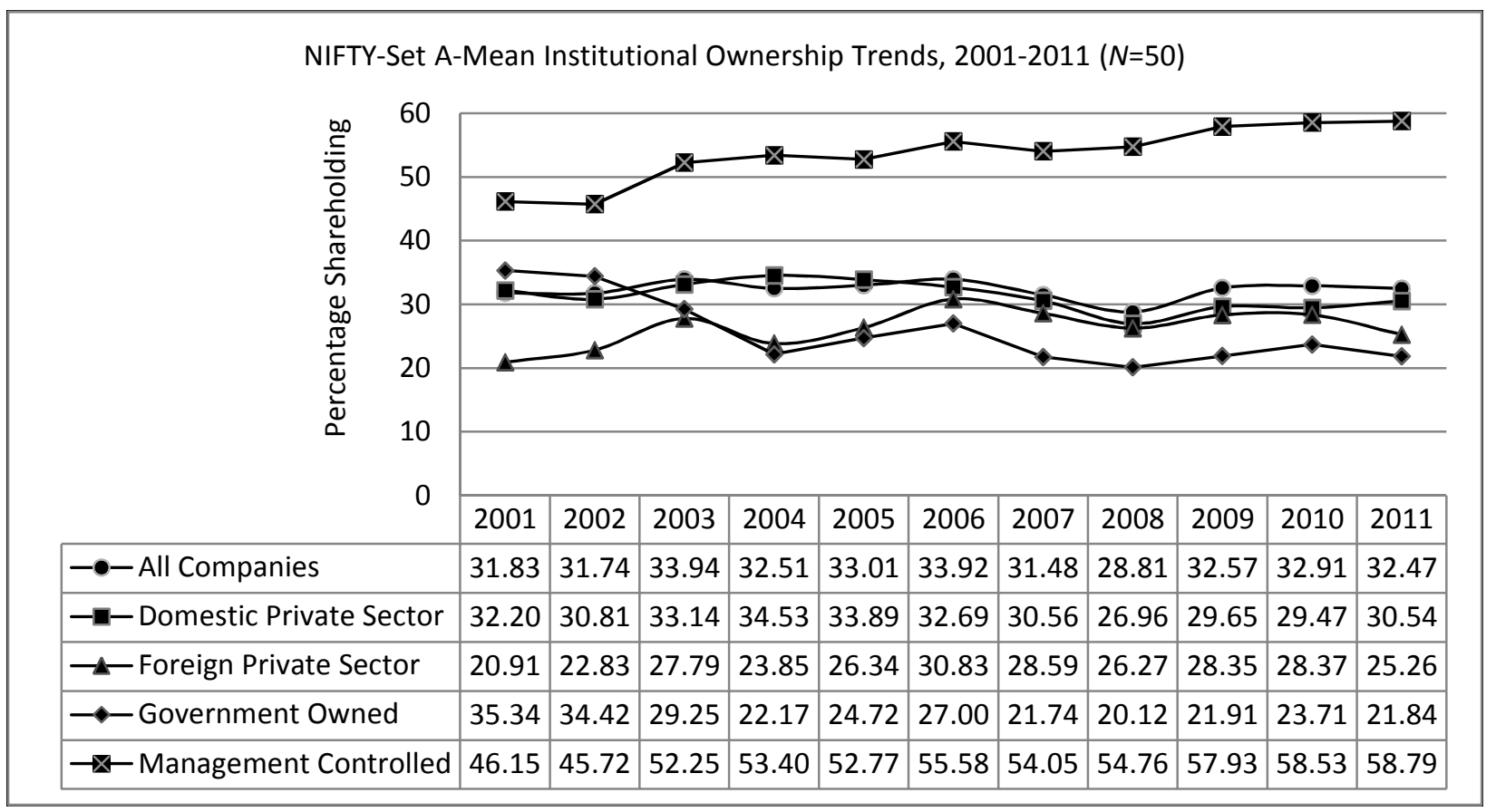

Exhibit AN-12 NIFTY-Set A-Median Institutional Ownership Trends, 2001-2011

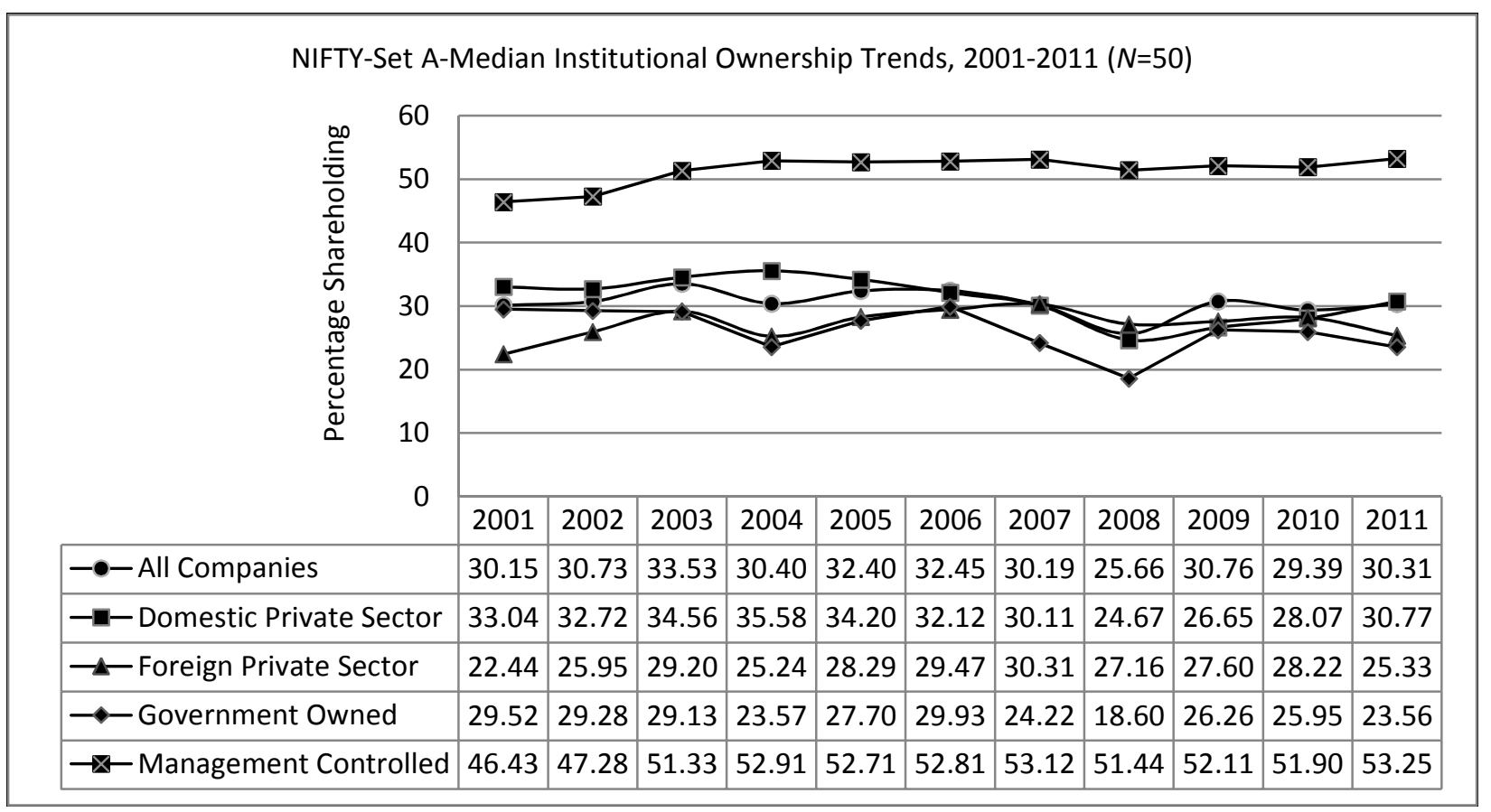


Exhibit AN-13 NIFTY-Set A-Mean Non Institutional Ownership Trends, 2001-2011

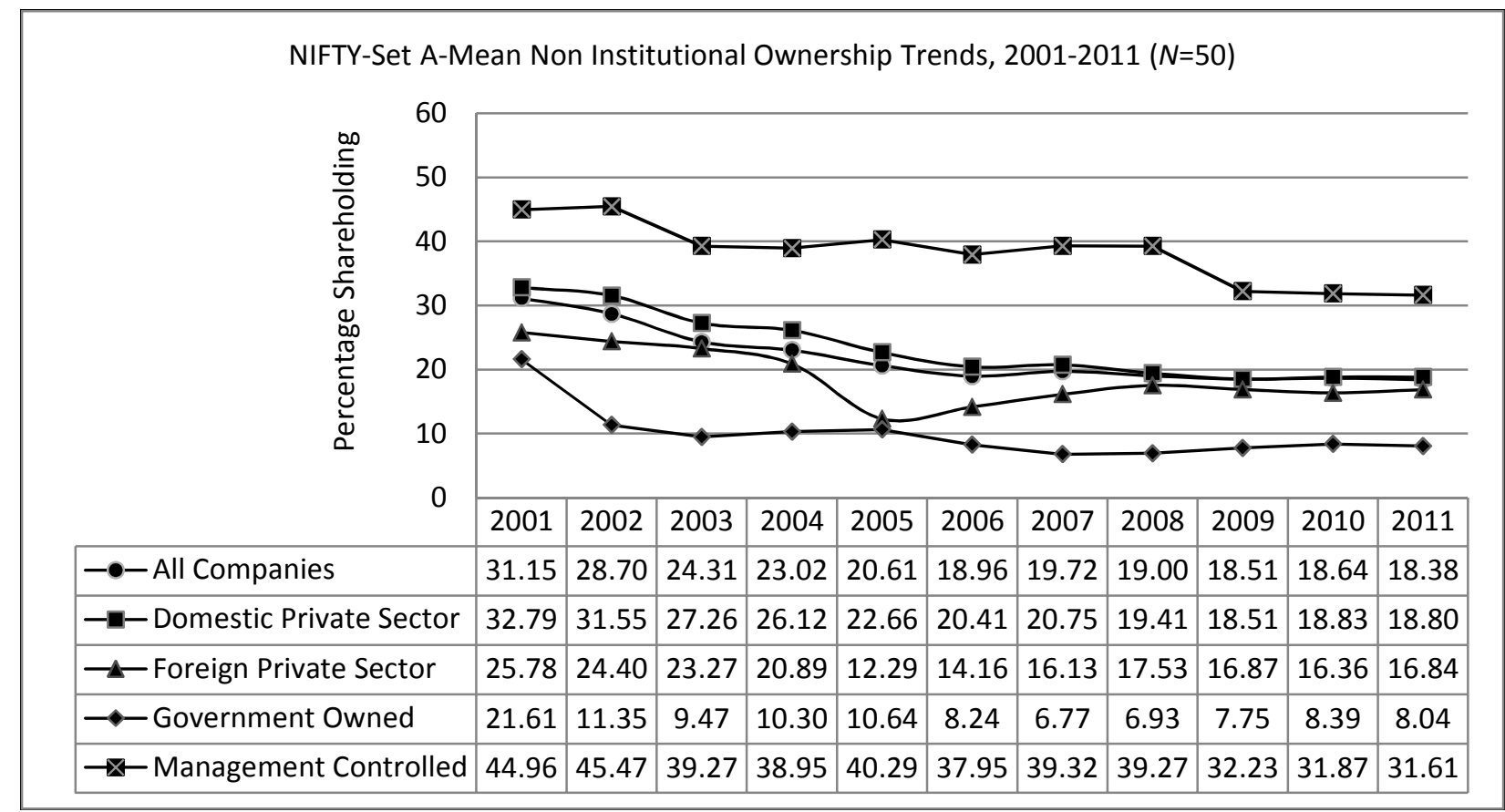

Exhibit AN-14 NIFTY-Set A-Median Non Institutional Ownership Trends, 2001-2011

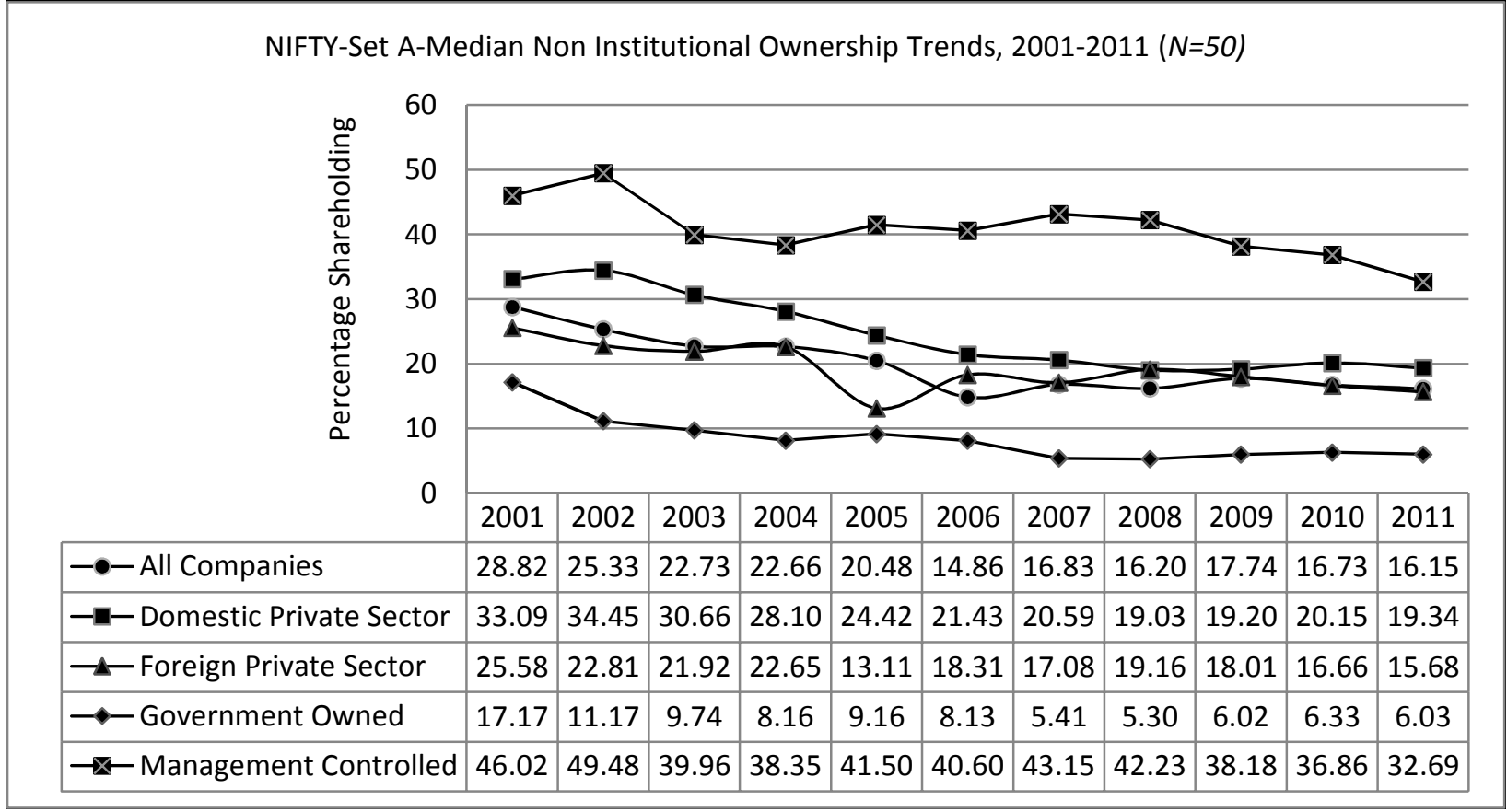


Exhibit AJ-1 JUNIOR NIFTY-Set A-Mean Ownership Trends, 2001-2011

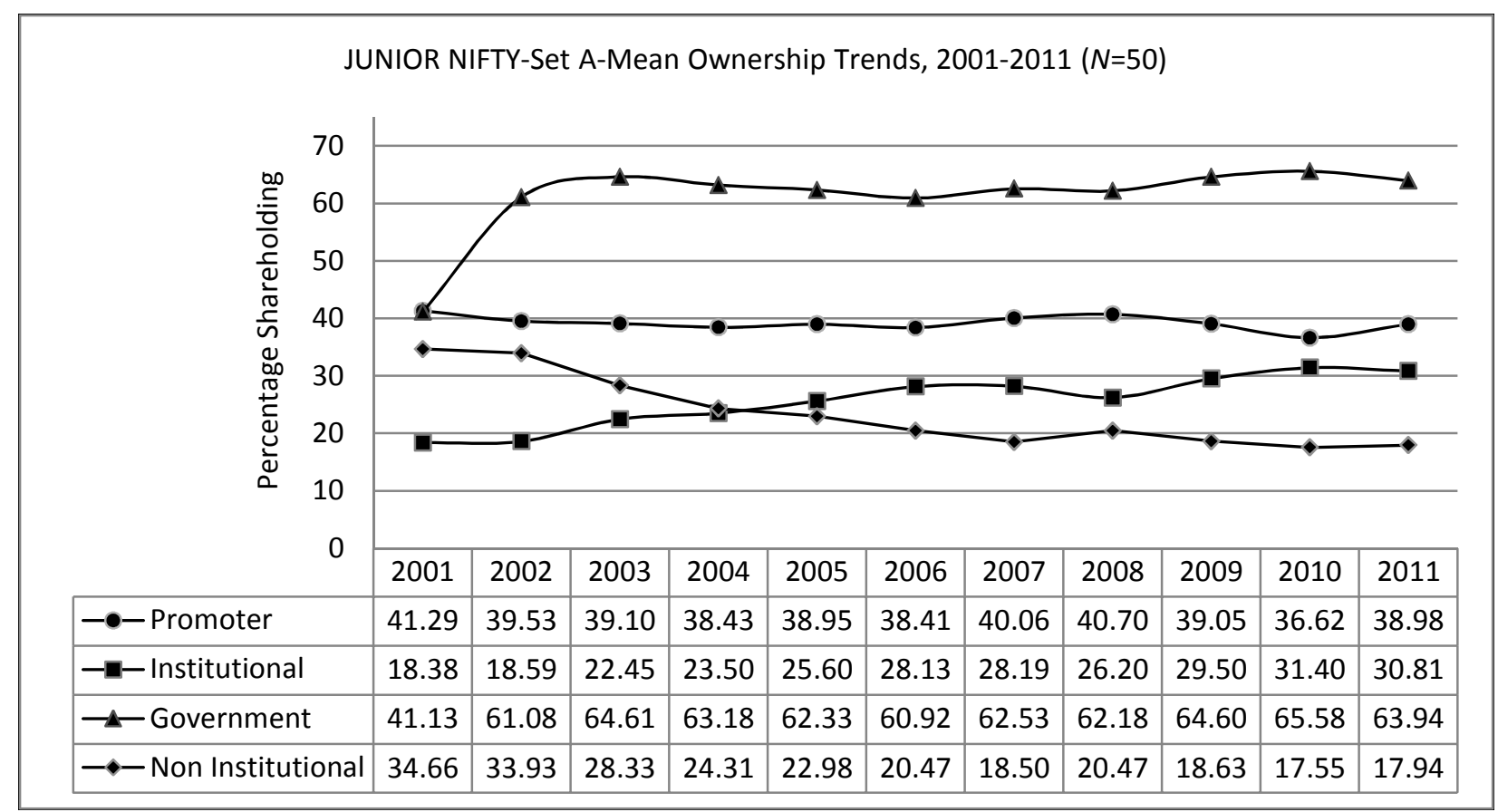

Exhibit AJ-2 JUNIOR NIFTY-Set A-Median Ownership Trends, 2001-2011 


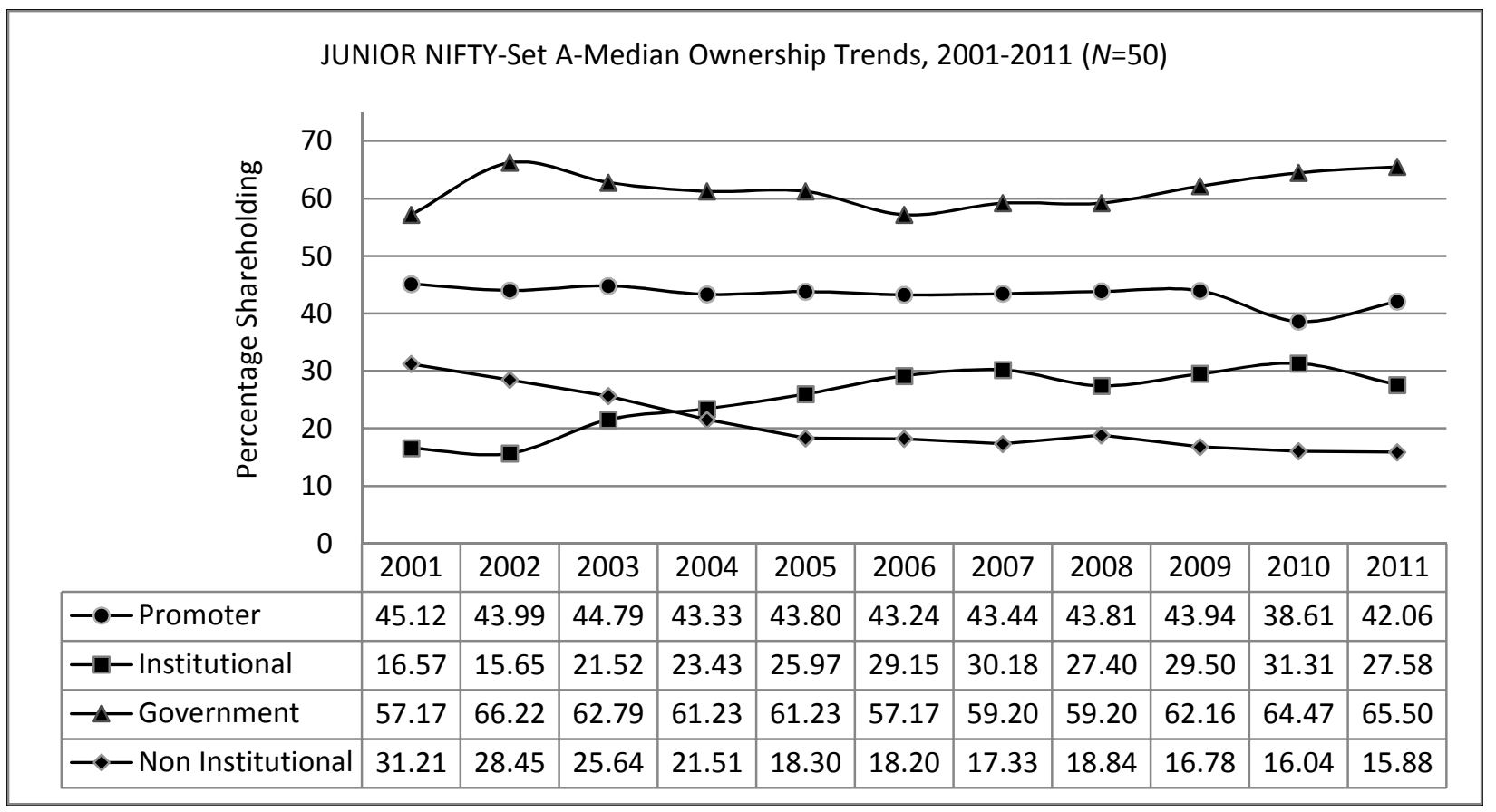

Exhibit AJ-3 JUNIOR NIFTY-Set A-Domestic Pvt. Sector Companies-Mean Ownership Trends, 2001-2011

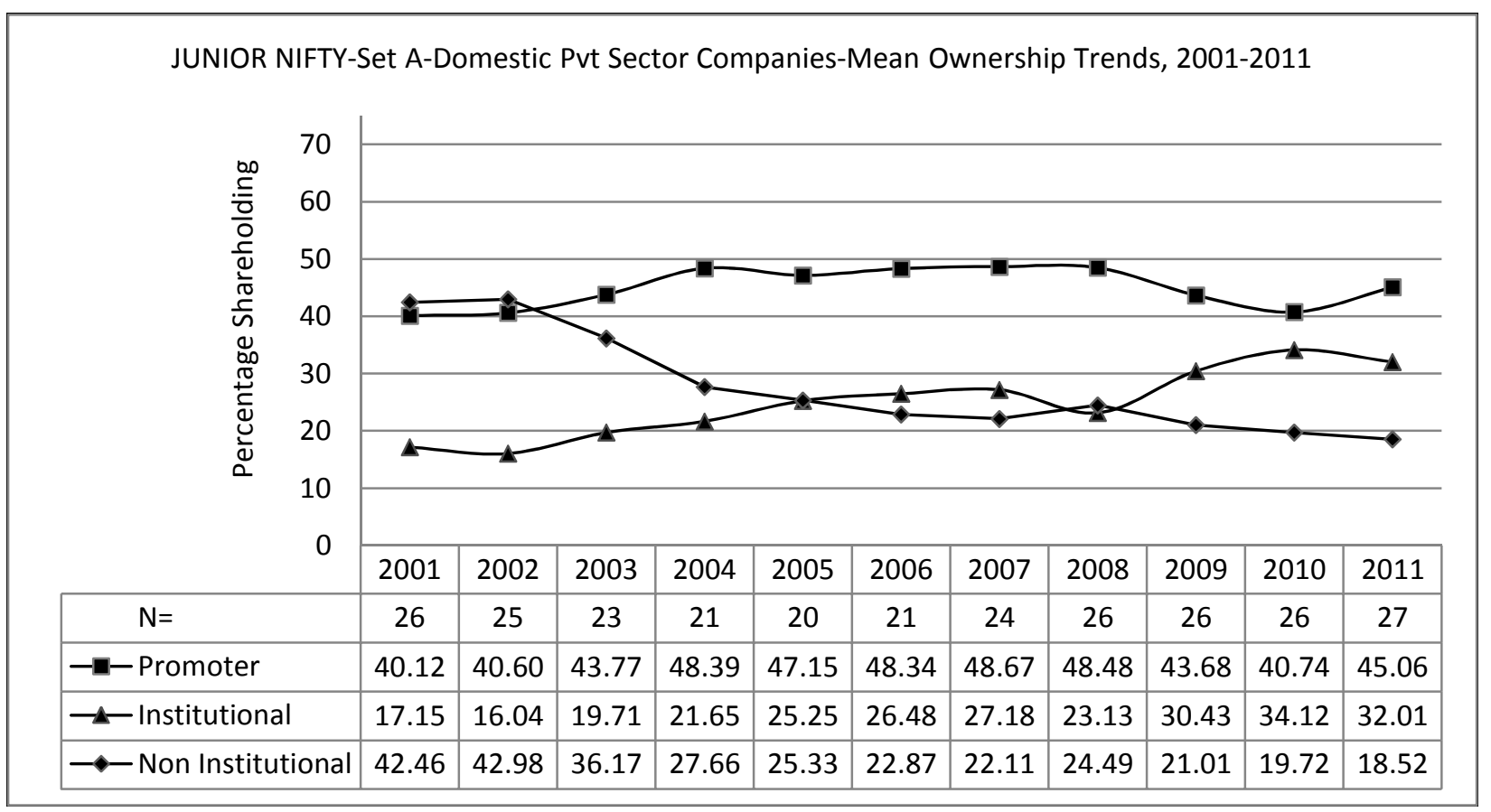


Exhibit AJ-4 JUNIOR NIFTY-Set A-Domestic Pvt. Sector Companies-Median Ownership Trends, 2001-2011

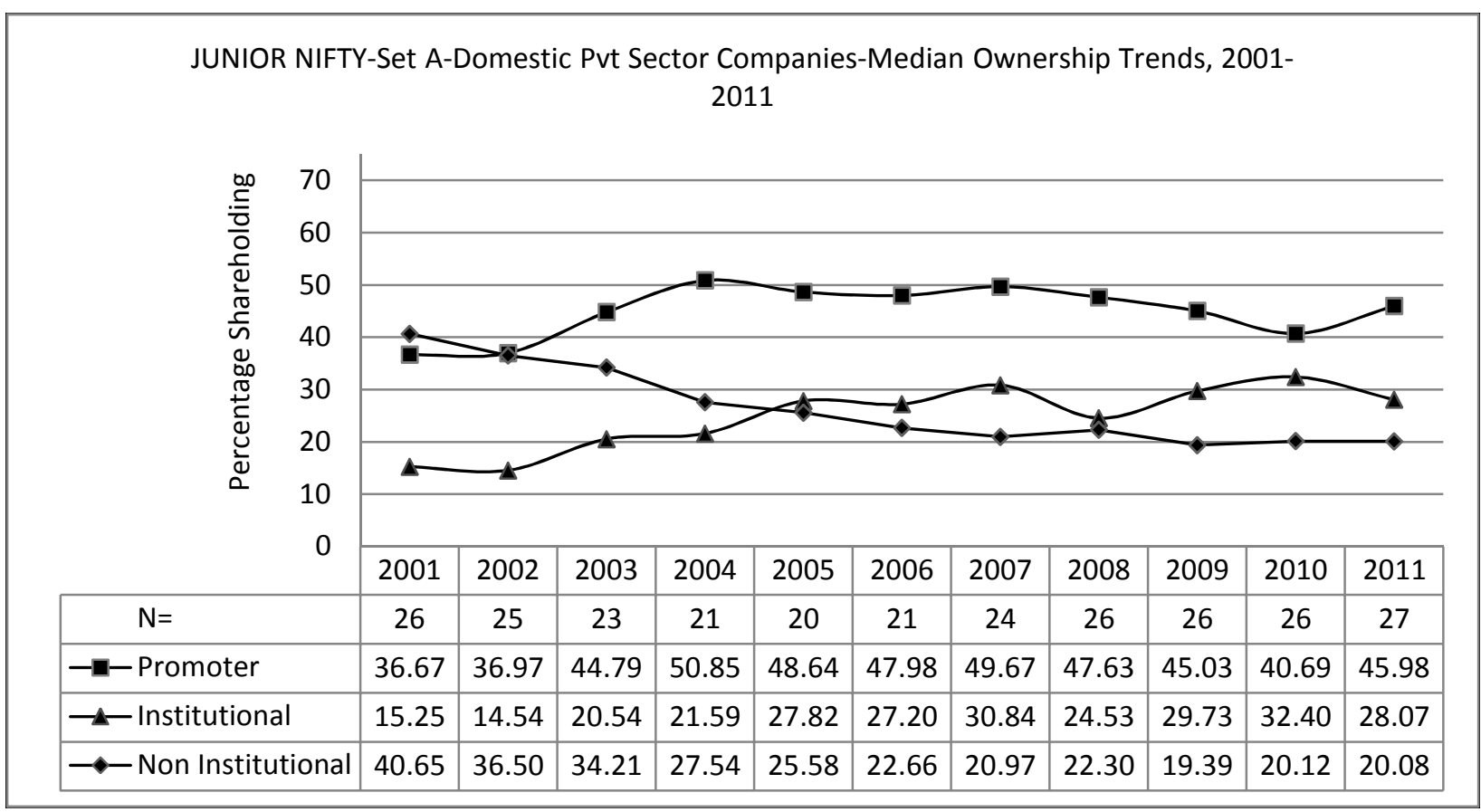

Exhibit AJ-5 JUNIOR NIFTY-Set A-Foreign Pvt. Sector Companies-Mean Ownership Trends, 2001-2011

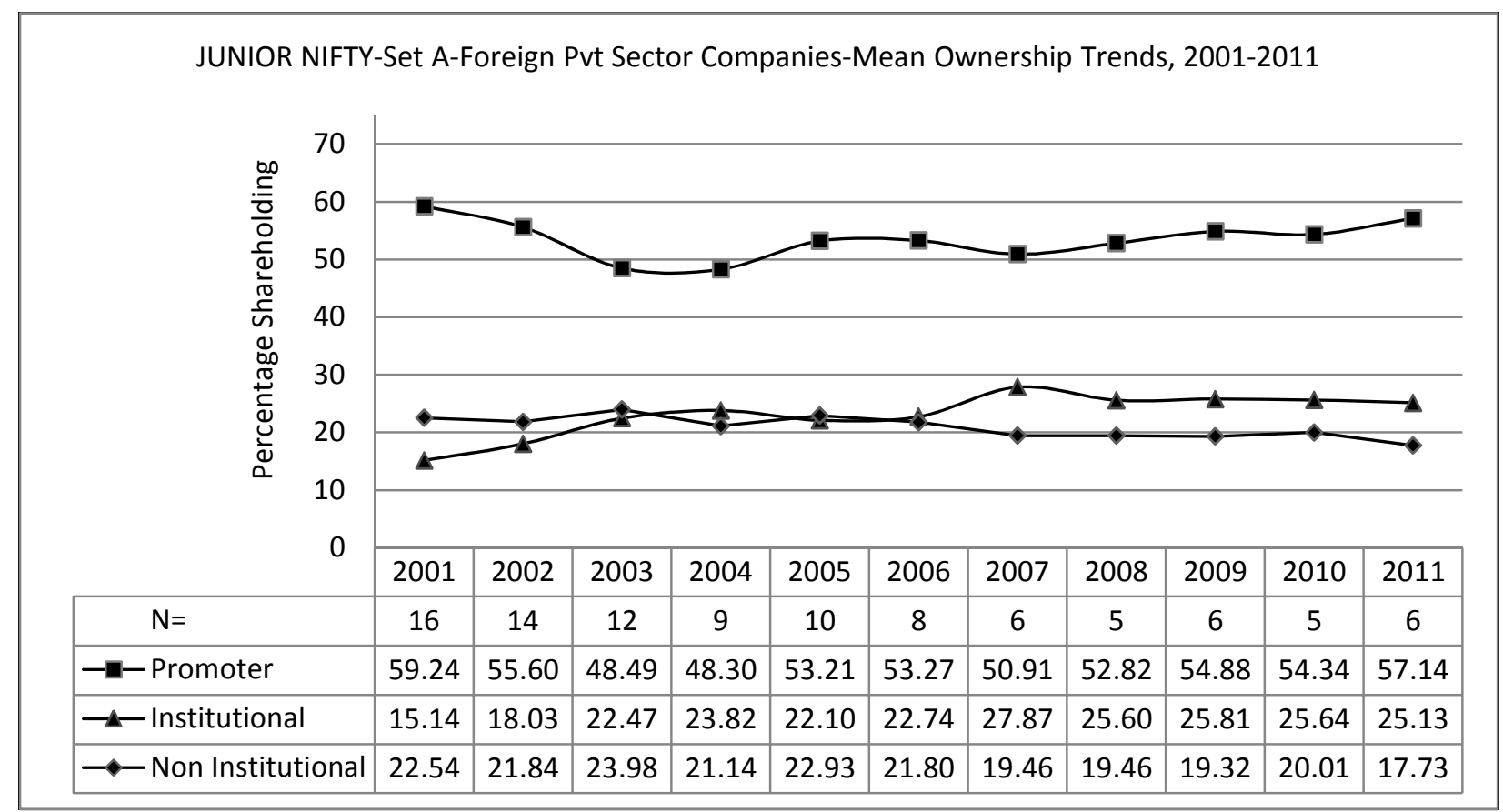


Exhibit AJ-6 JUNIOR NIFTY-Set A-Foreign Pvt. Sector Companies-Median Ownership Trends, 2001-2011

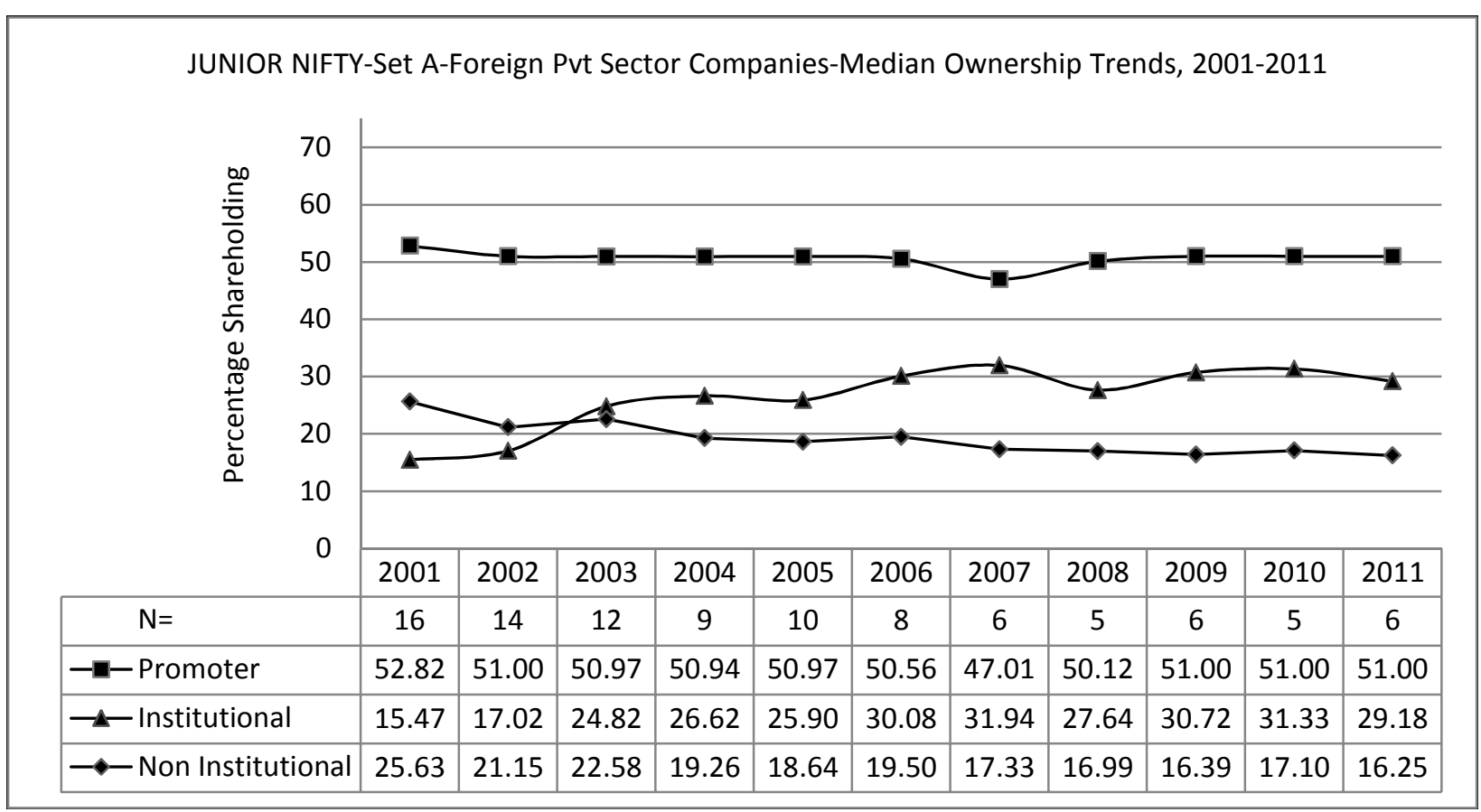

Exhibit AJ-7 JUNIOR NIFTY-Set A-Government Owned Companies-Mean Ownership Trends, 2001-2011 
JUNIOR NIFTY-Set A-Government Owned Companies-Mean Ownership Trends, 2001-2011

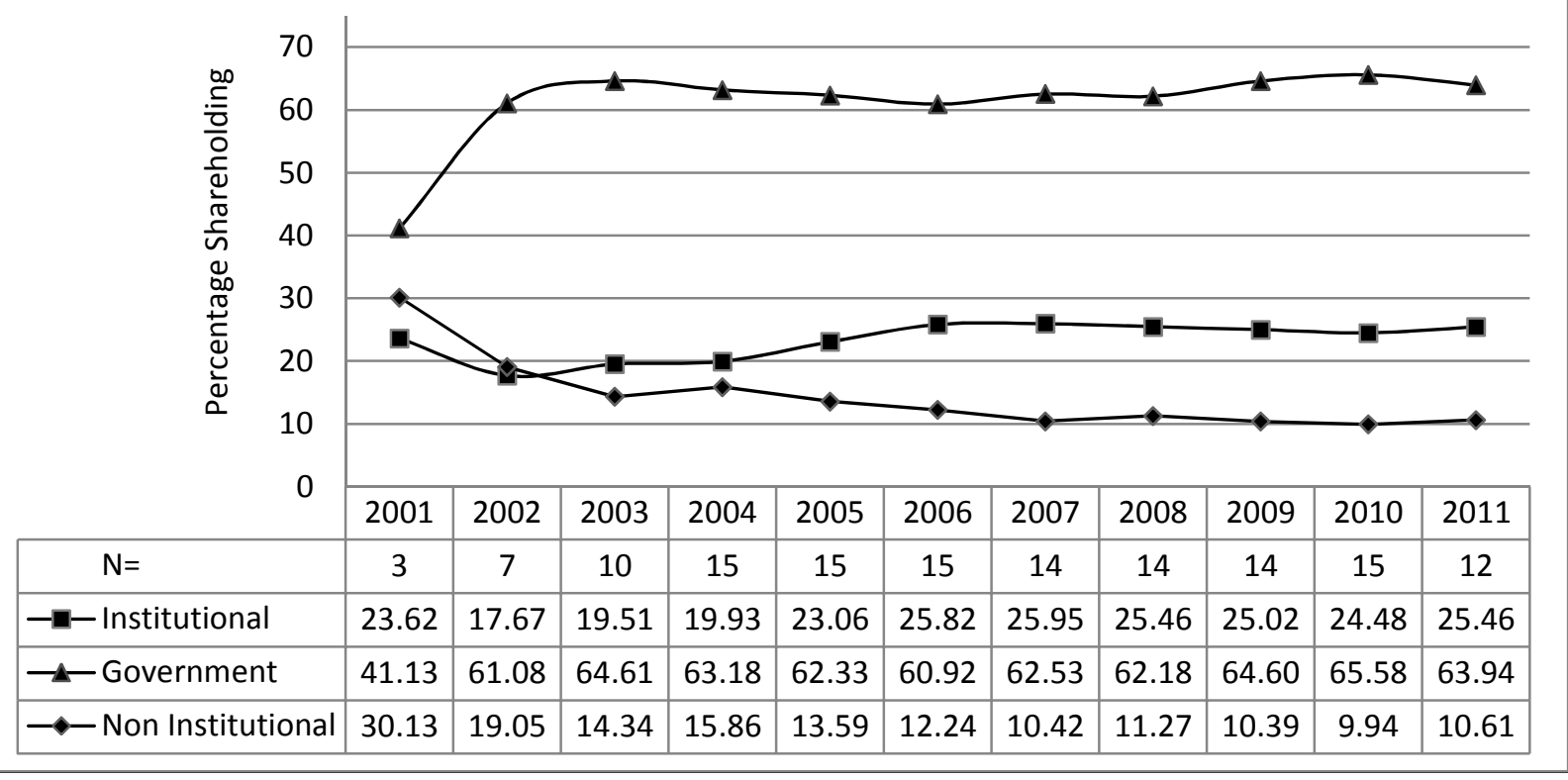

Exhibit AJ-8 JUNIOR NIFTY-Set A-Government Owned Companies-Median Ownership Trends, 2001-2011

JUNIOR NIFTY-Set A-Government Owned Companies-Median Ownership Trends, 20012011

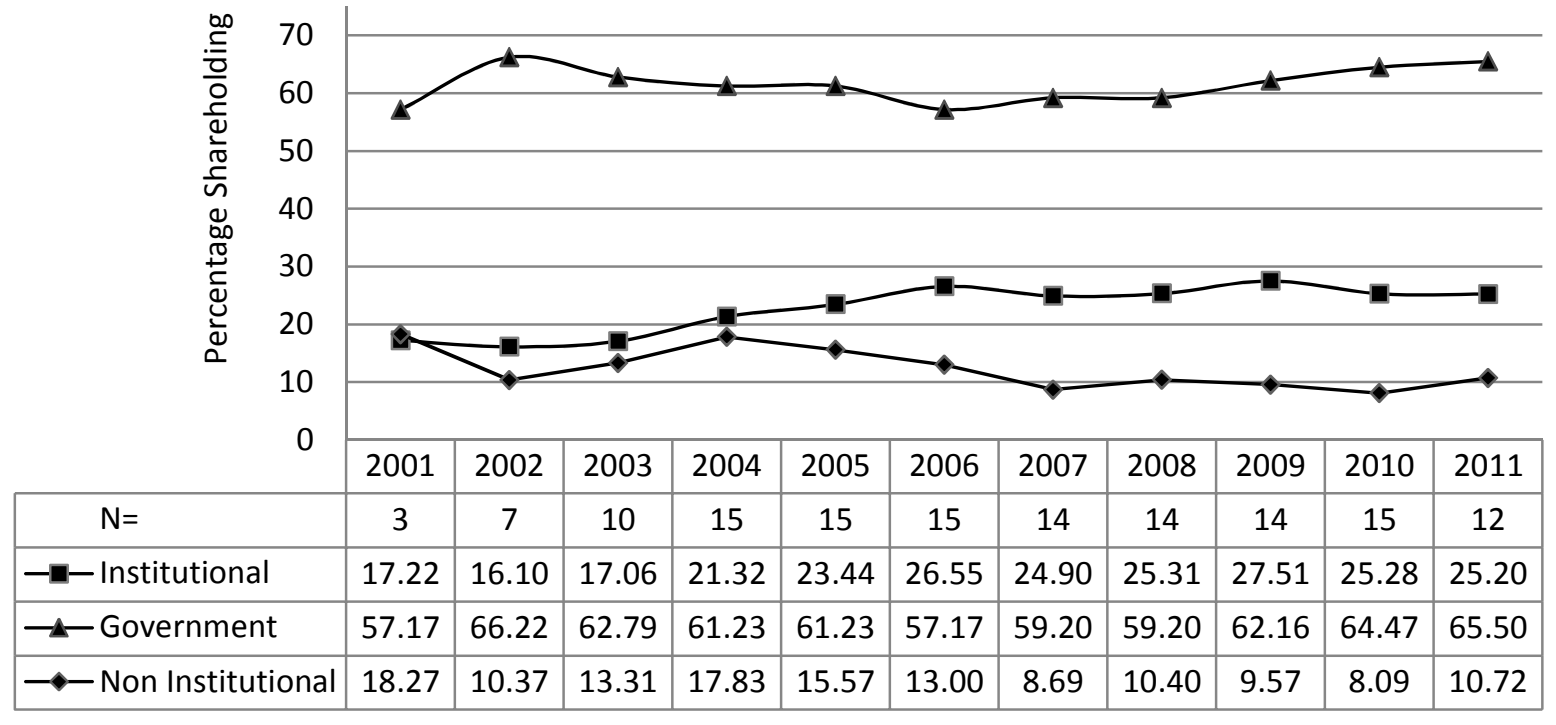

Exhibit AJ-9 JUNIOR NIFTY-Set A-Management Controlled Companies-Mean Ownership Trends, 2001-2011 
JUNIOR NIFTY-Set A-Management Controlled Companies-Mean Ownership Trends, 20012011

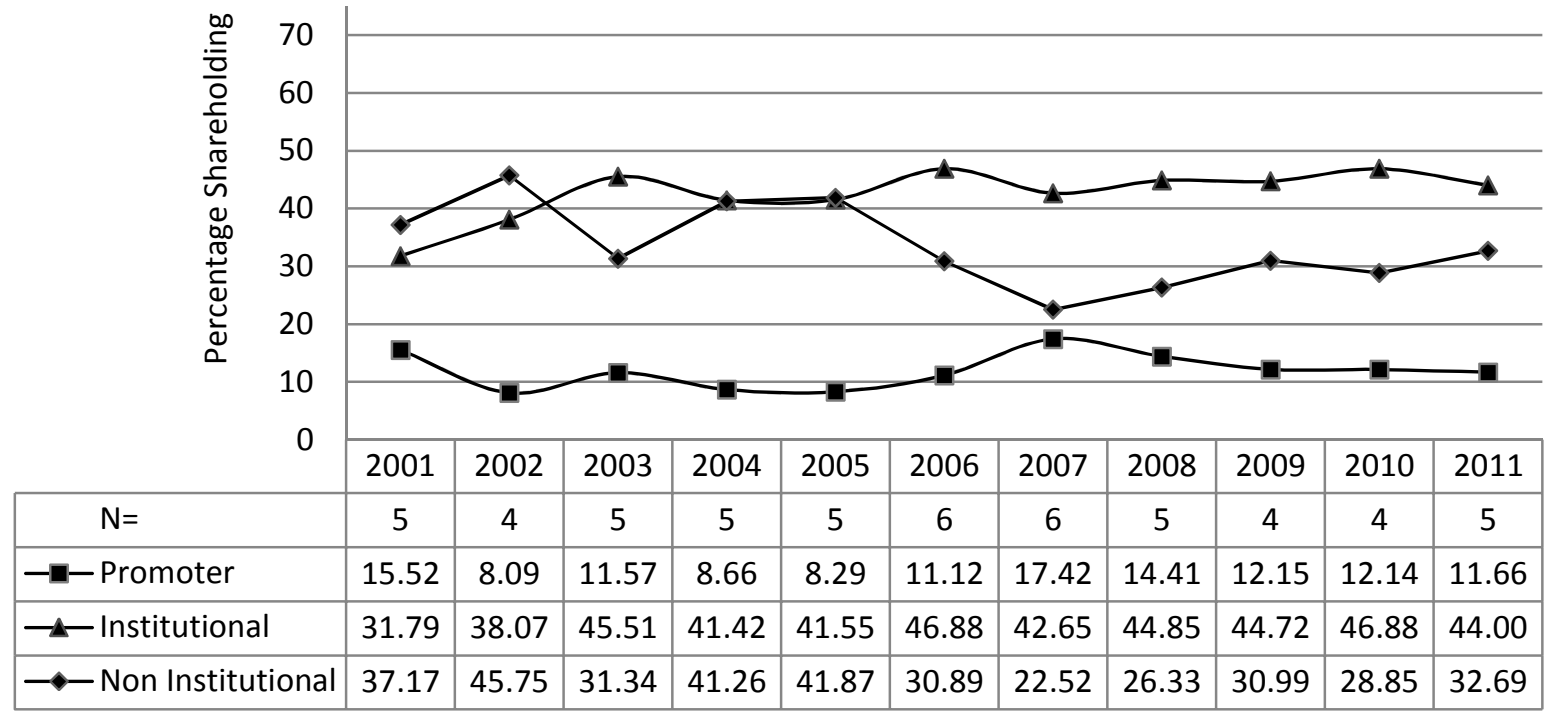

Exhibit AJ-10 JUNIOR NIFTY-Set A-Management Controlled Companies-Median Ownership Trends, 2001-2011

JUNIOR NIFTY-Set A-Management Controlled Companies-Mean Ownership Trends, 20012011

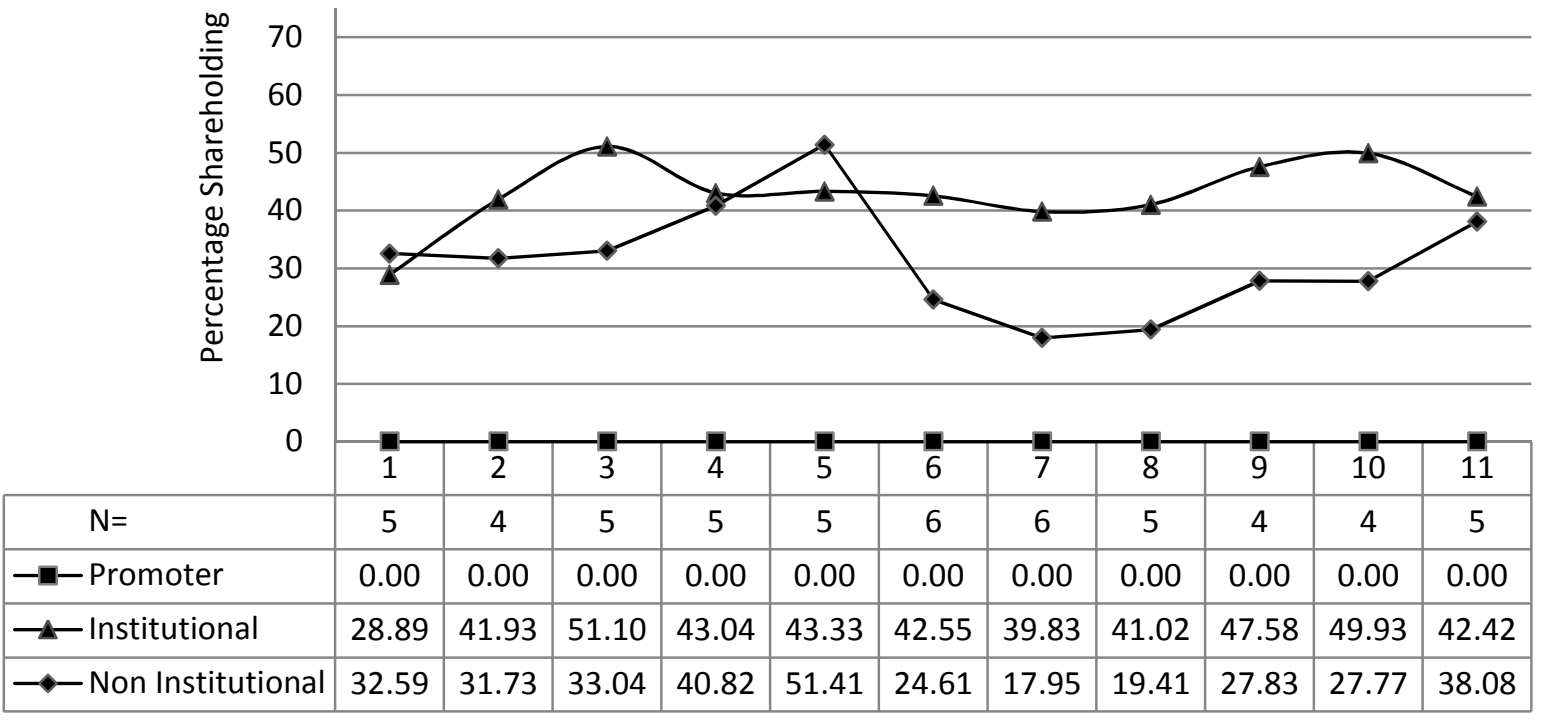

Exhibit AJ-11 JUNIOR NIFTY-Set A-Mean Institutional Ownership Trends, 2001-2011 
JUNIOR NIFTY-Set A-Mean Institutional Ownership Trends, 2001-2011 ( $N=50)$

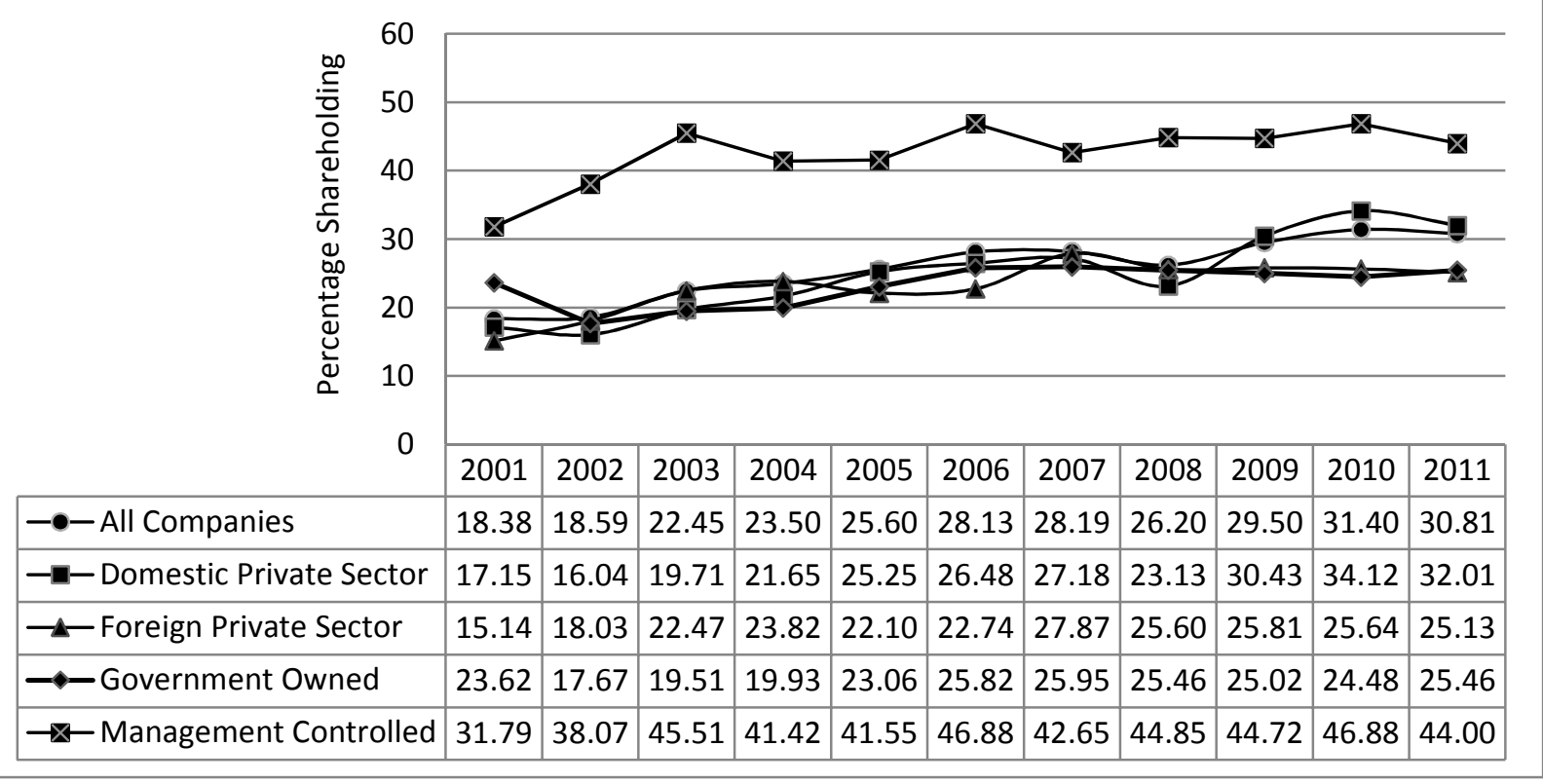

Exhibit AJ-12 JUNIOR NIFTY-Set A-Median Institutional Ownership Trends, 2001-2011

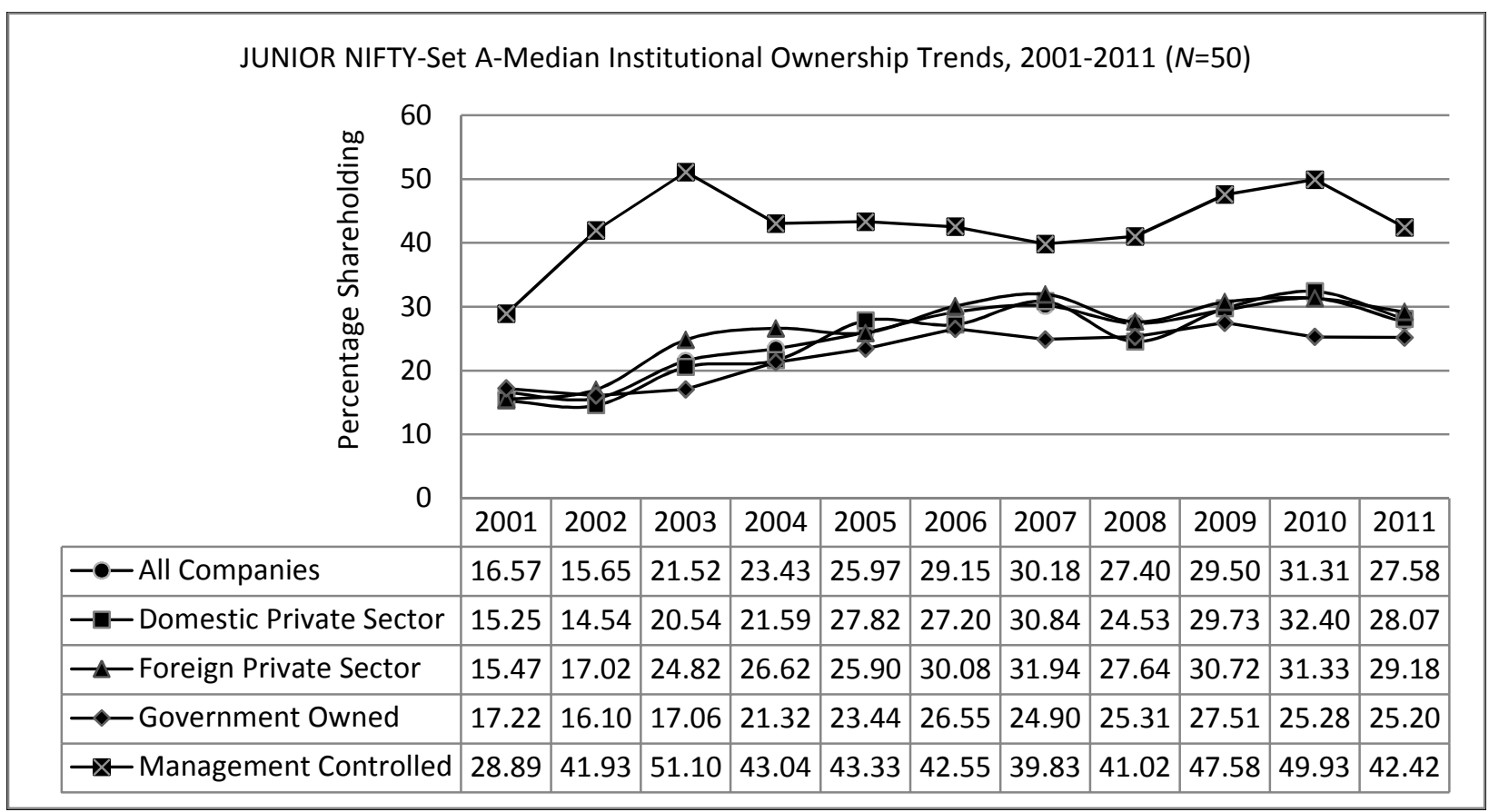


Exhibit AJ-13 JUNIOR NIFTY-Set A-Mean Non Institutional Ownership Trends, 2001-2011

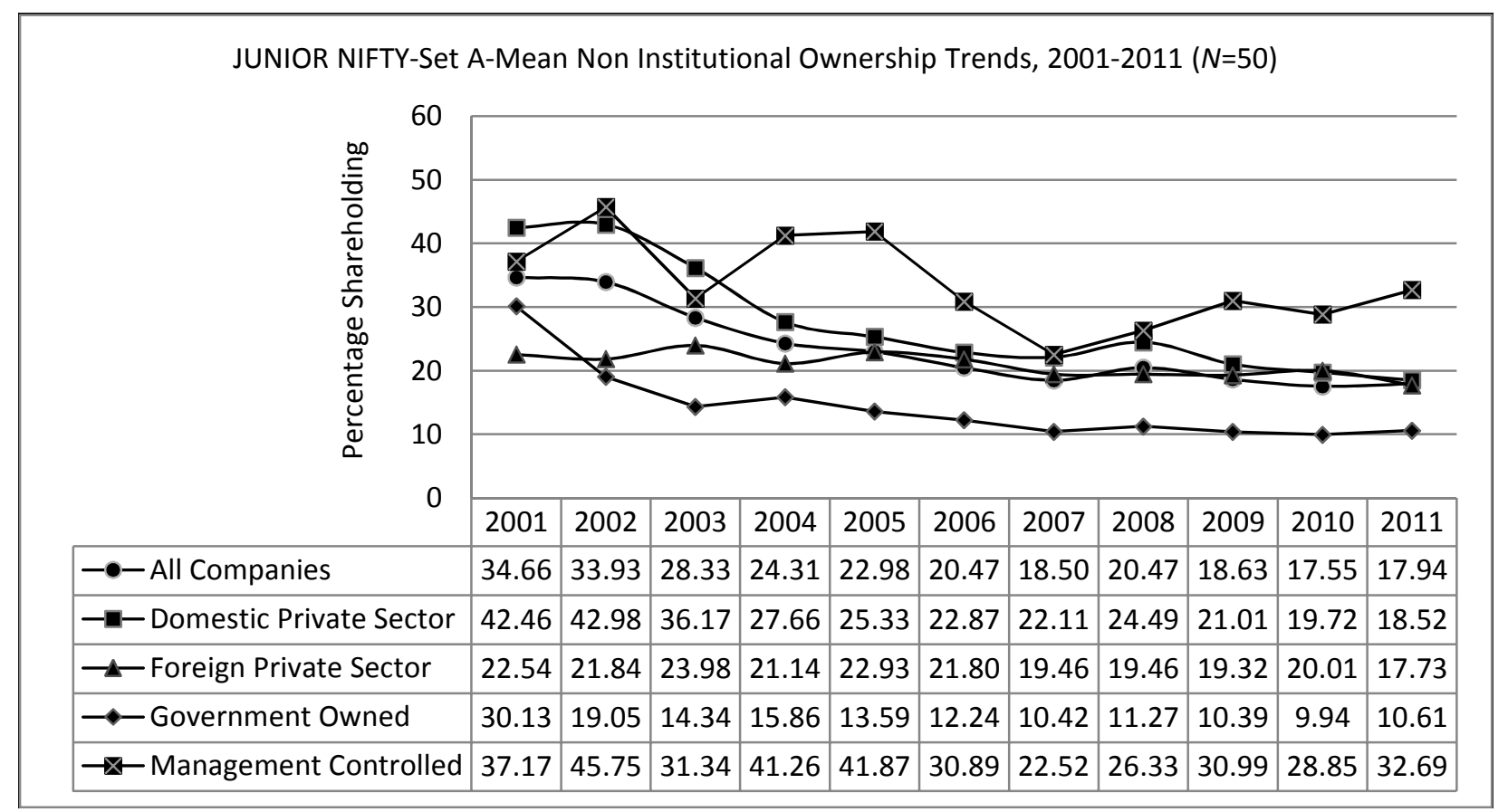

Exhibit AJ-14 JUNIOR NIFTY-Set A-Median Non Institutional Ownership Trends, 2001-2011

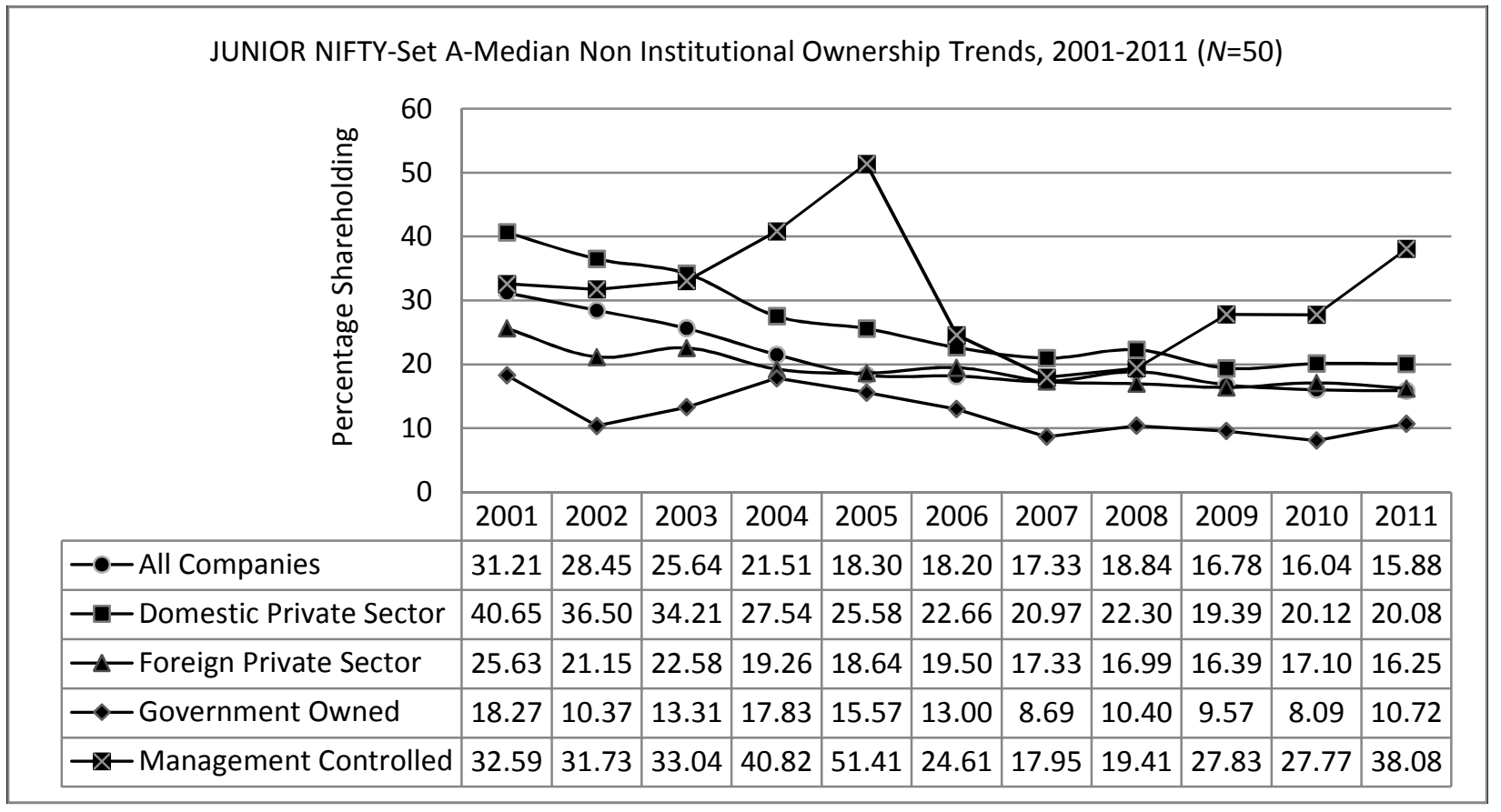


Exhibit AC-1 CNX-100-Set A-Mean Ownership Trends, 2001-2011

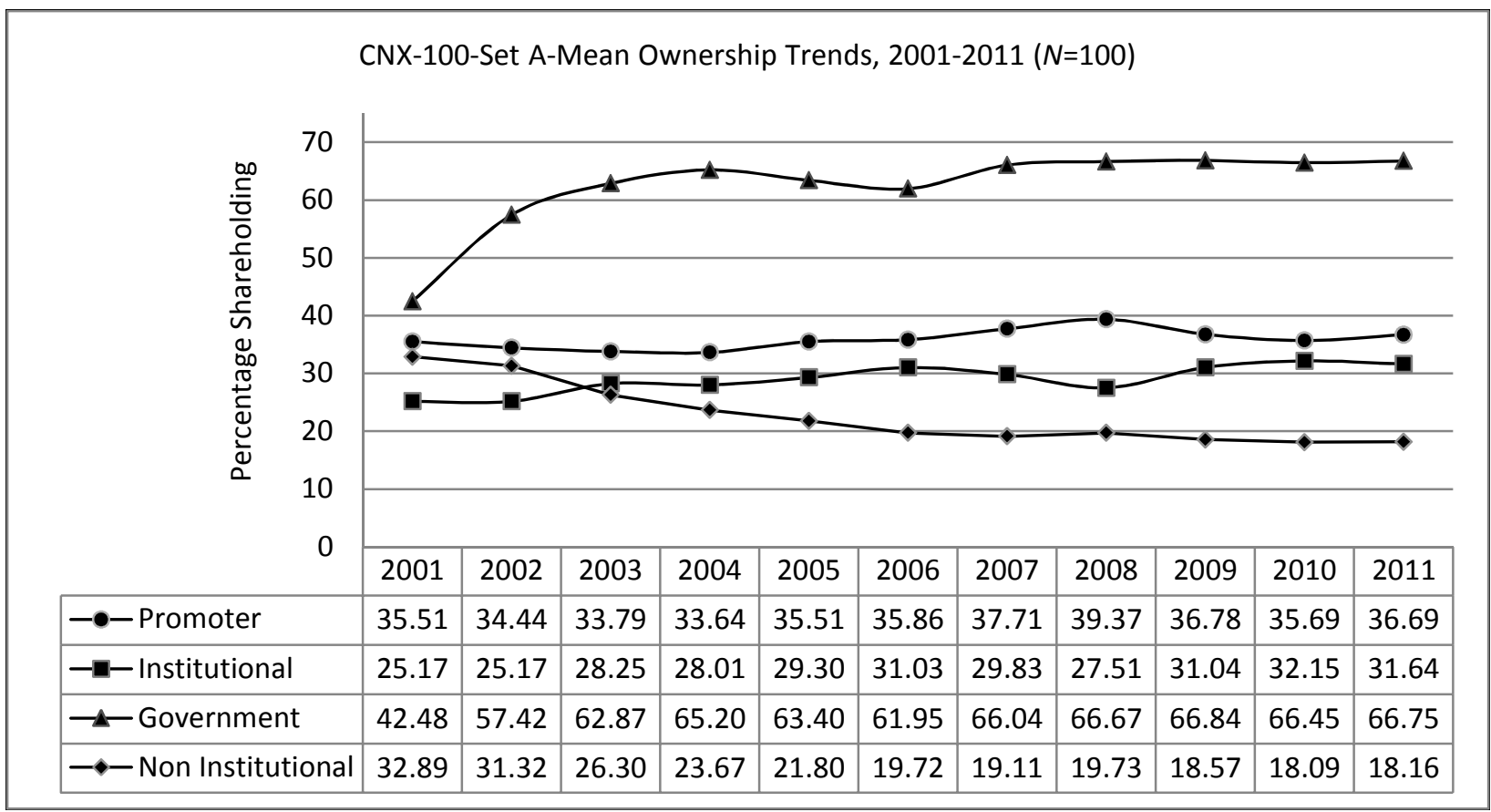

Exhibit AC-2 CNX-100-Set A-Median Ownership Trends, 2001-2011

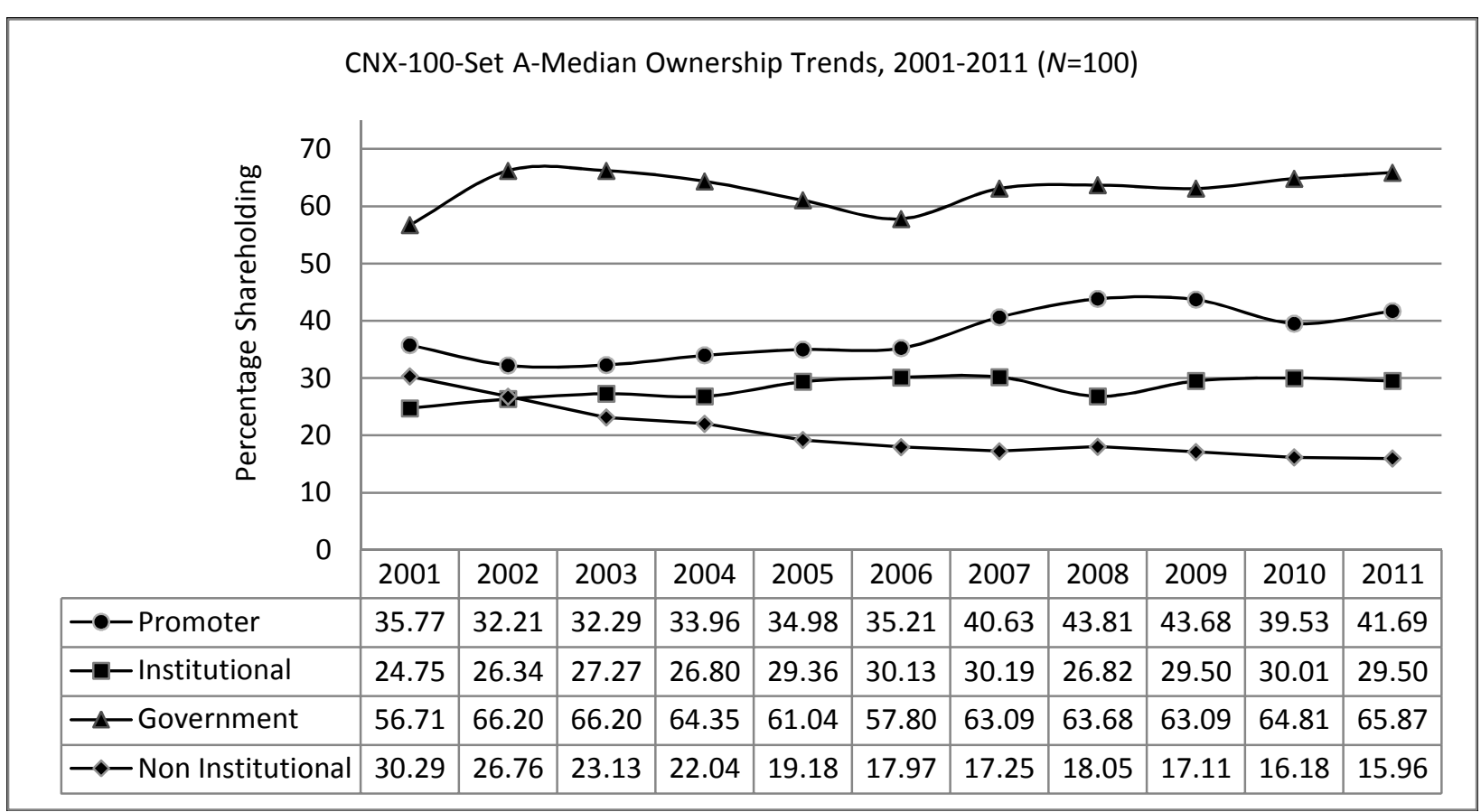


Exhibit AC-3 CNX-100-Set A-Domestic Pvt. Sector Companies-Mean Ownership Trends, 2001-2011

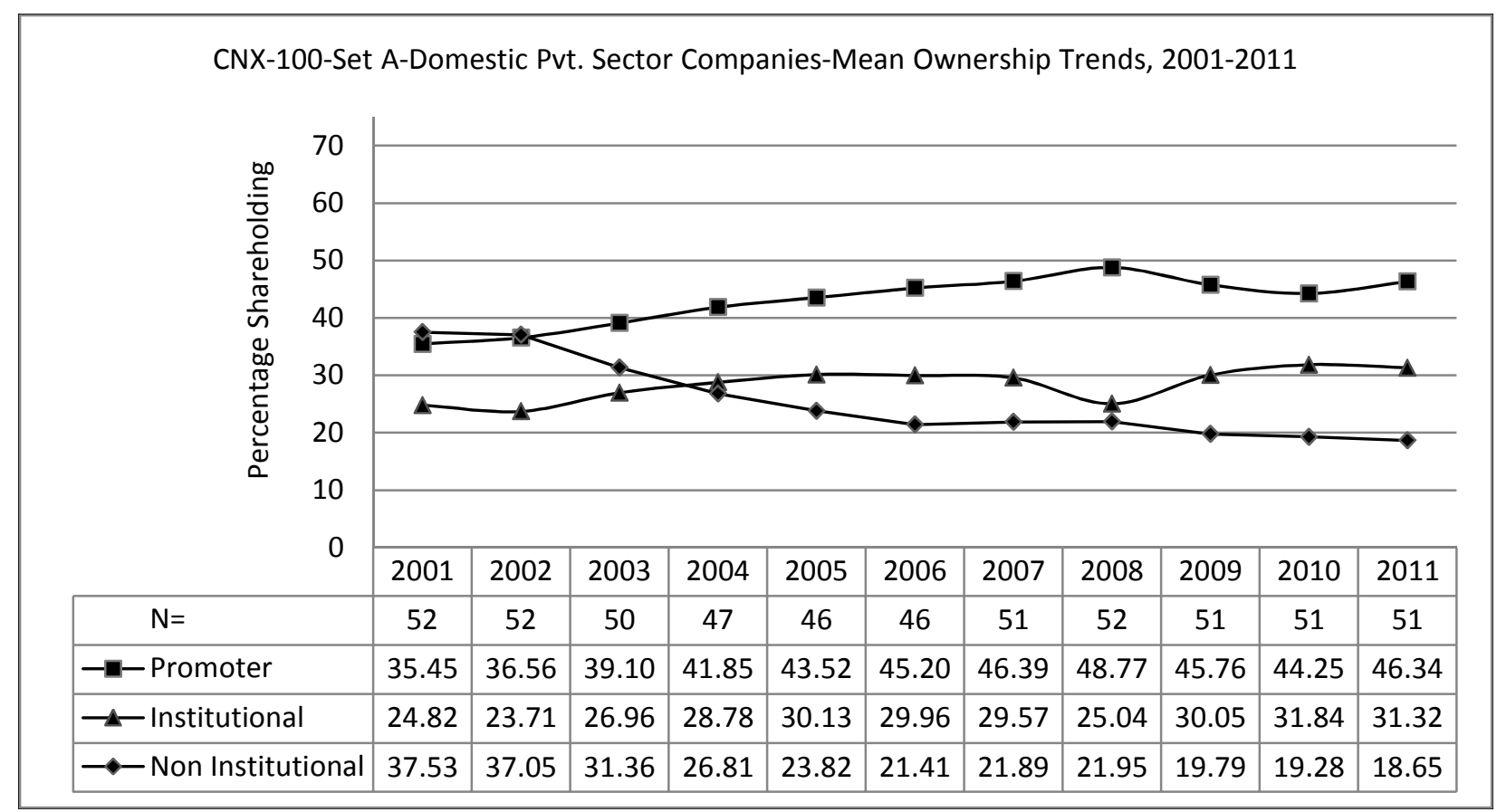

Exhibit AC-4 CNX-100-Set A-Domestic Pvt. Sector Companies-Median Ownership Trends, 2001-2011 
CNX-100-Set A-Domestic Pvt. Sector Companies-Median Ownership Trends, 2001-2011

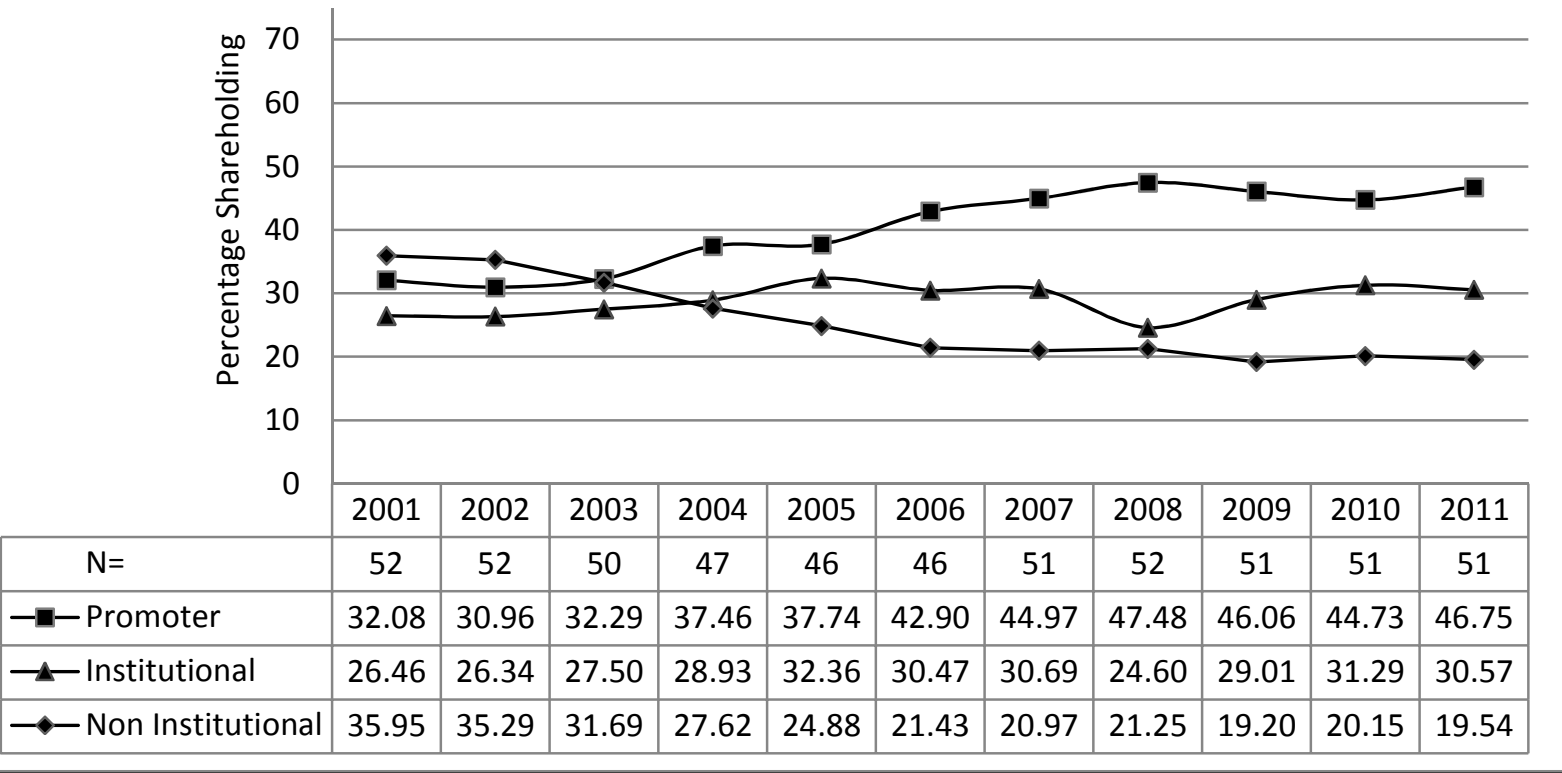

Exhibit AC-5 CNX-100-Set A-Foreign Pvt. Sector Companies-Mean Ownership Trends, 20012011

CNX-100-Set A-Foreign Pvt. Sector Companies-Mean Ownership Trends, 2001-2011

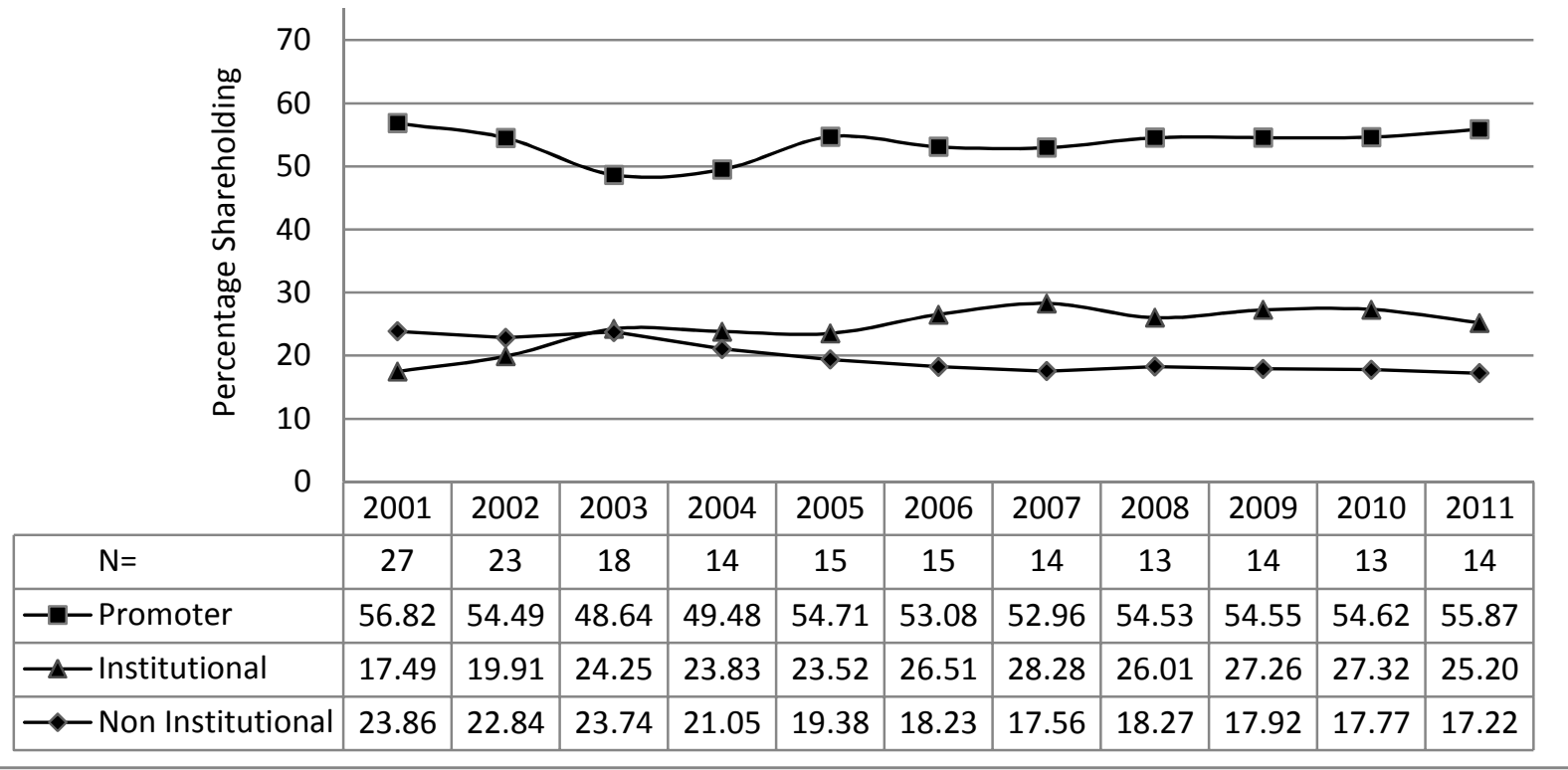


Exhibit AC-6 CNX-100-Set A-Foreign Pvt. Sector Companies-Median Ownership Trends, 2001-2011

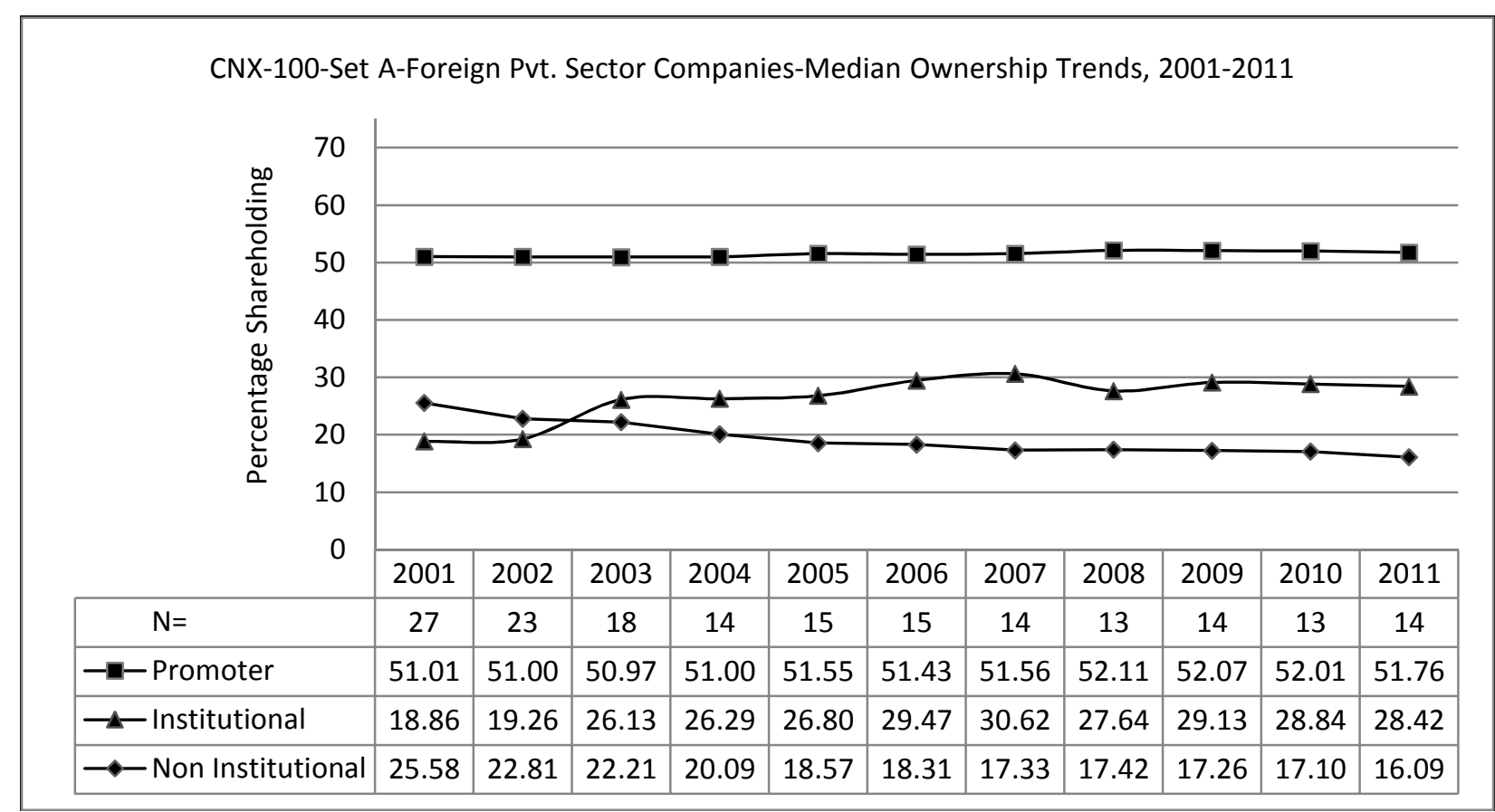

Exhibit AC-7 CNX-100-Set A-Government Owned Companies-Mean Ownership Trends, 20012011

CNX-100-Set A-Government Owned Companies-Mean Ownership Trends, 2001-2011

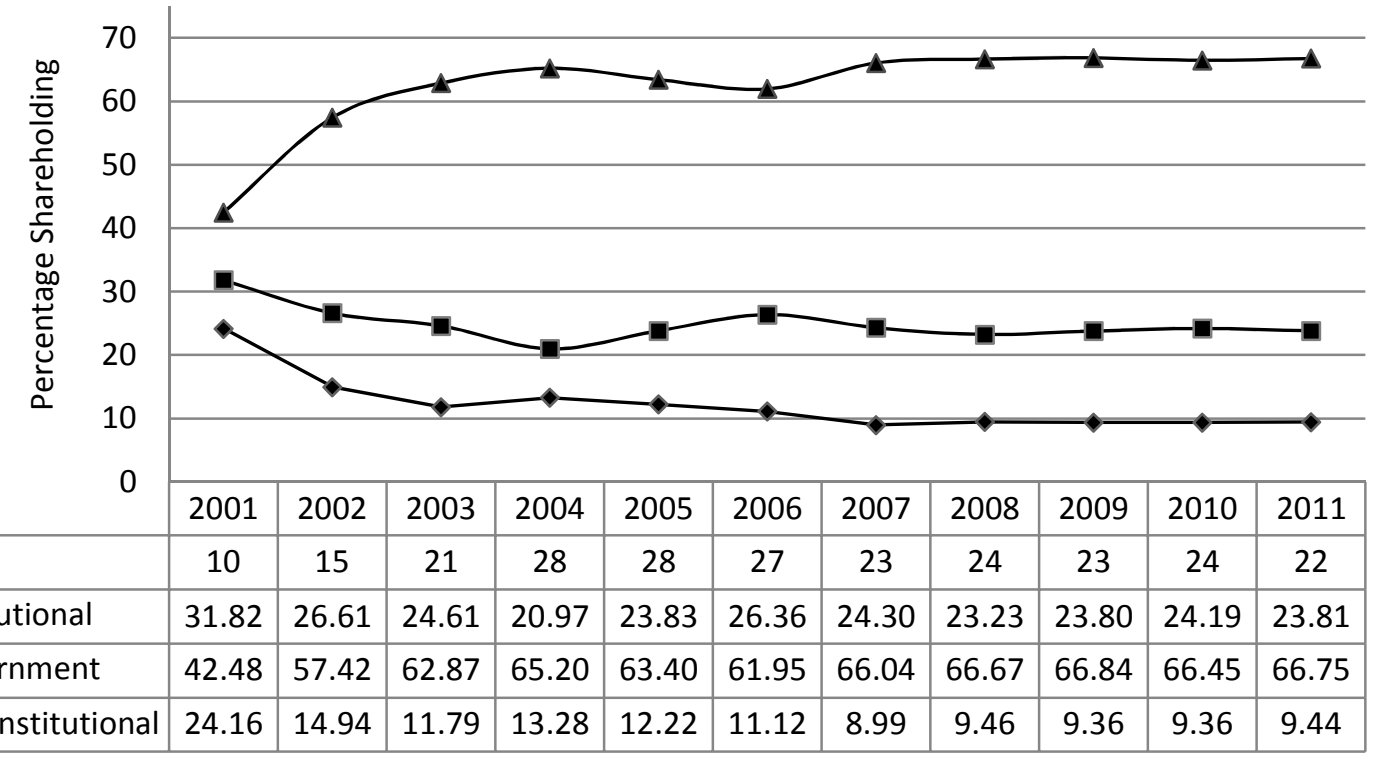


Exhibit AC-8 CNX-100-Set A-Government Owned Companies-Median Ownership Trends, 2001-2011

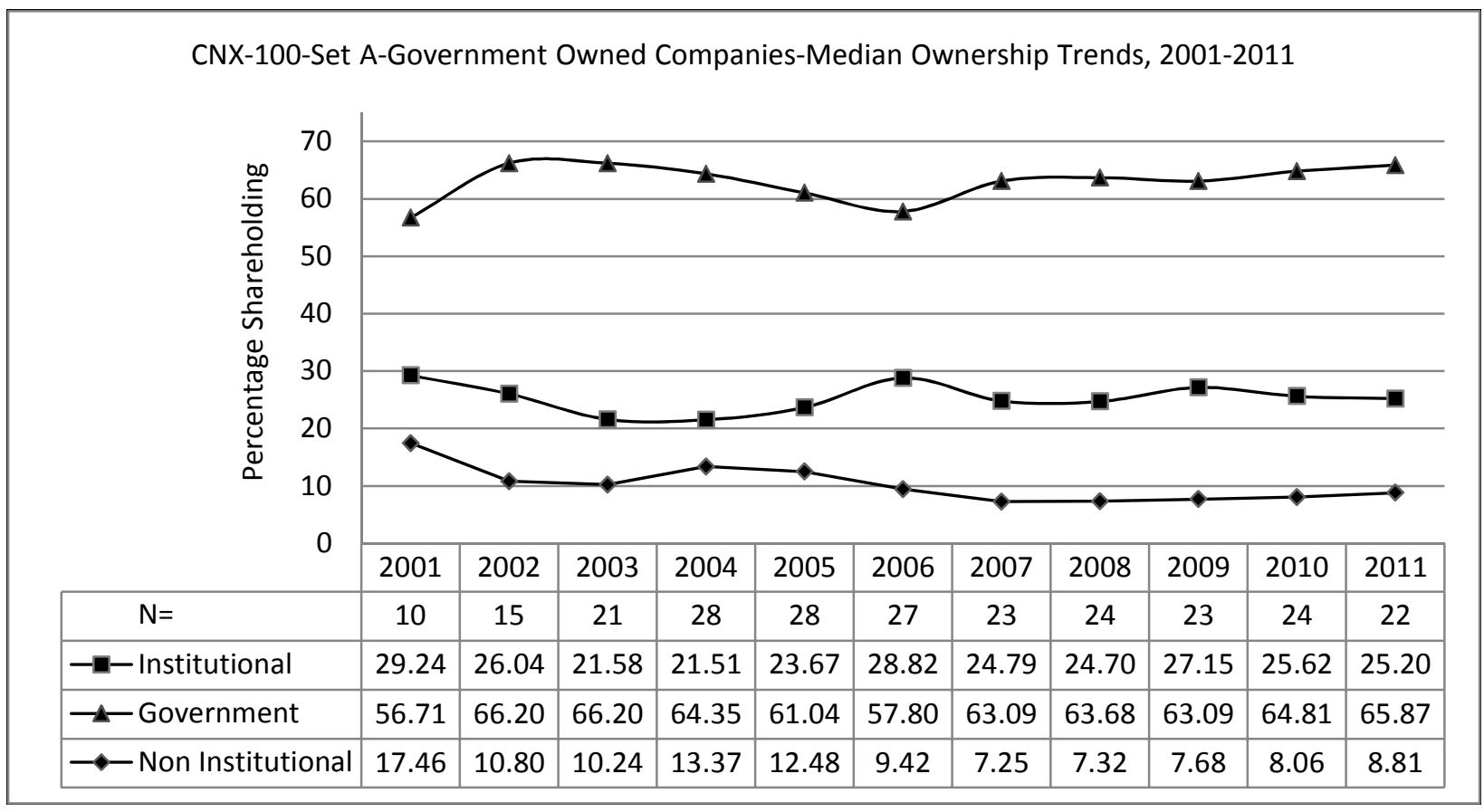

Exhibit AC-9 CNX-100-Set A-Management Controlled Companies-Mean Ownership Trends, 2001-2011

CNX-100-Set A-Management Controlled Companies-Mean Ownership Trends, 2001-2011

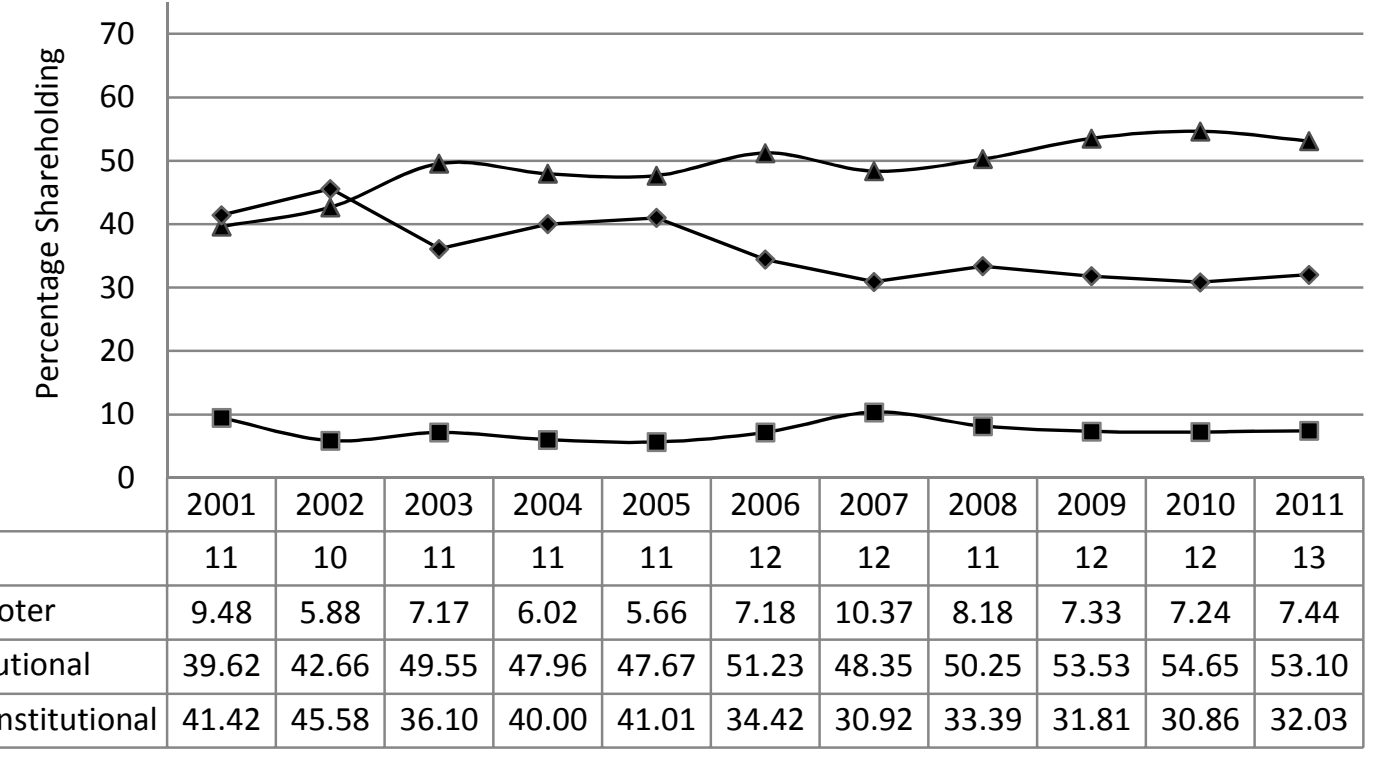


Exhibit AC-10 CNX-100-Set A-Management Controlled Companies-Median Ownership Trends, 2001-2011

CNX-100-Set A-Management Controlled Companies-Median Ownership Trends, 20012011

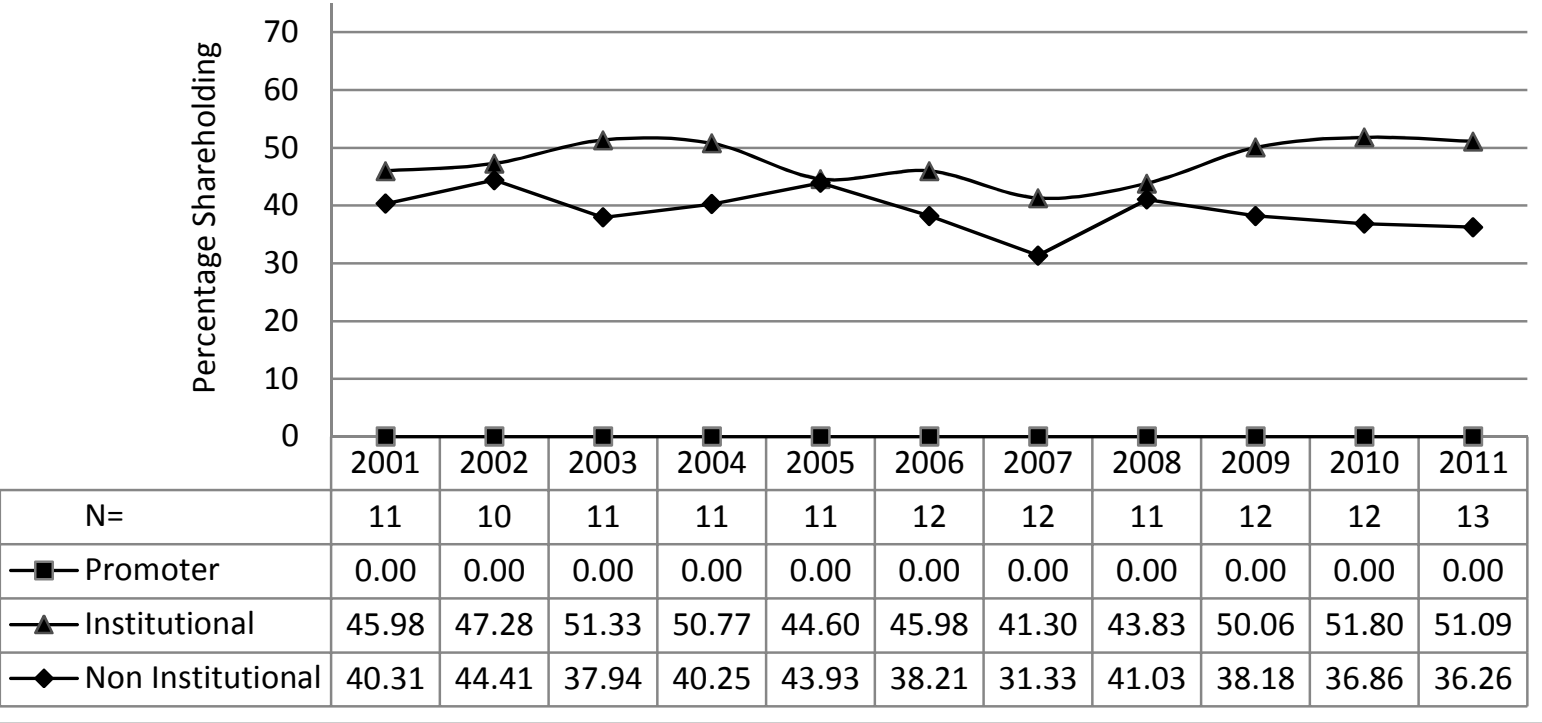

Exhibit AC-11 CNX-100-Set A-Mean Institutional Ownership Trends, 2001-2011 
CNX-100-Set A-Mean Institutional Ownership Trends, 2001-2011 ( $N=100)$

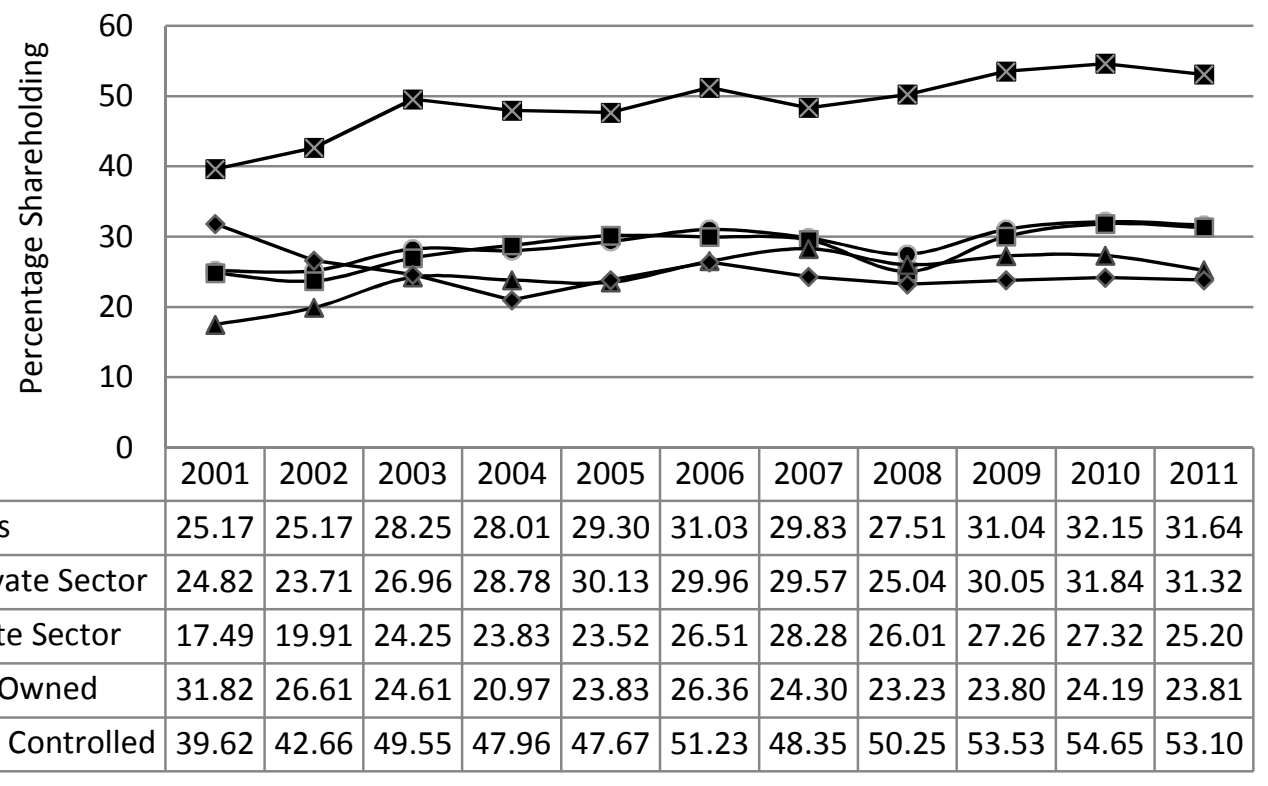

Exhibit AC-12 CNX-100-Set A-Median Institutional Ownership Trends, 2001-2011

CNX-100-Set A-Median Institutional Ownership Trends, 2001-2011 ( $N=100)$

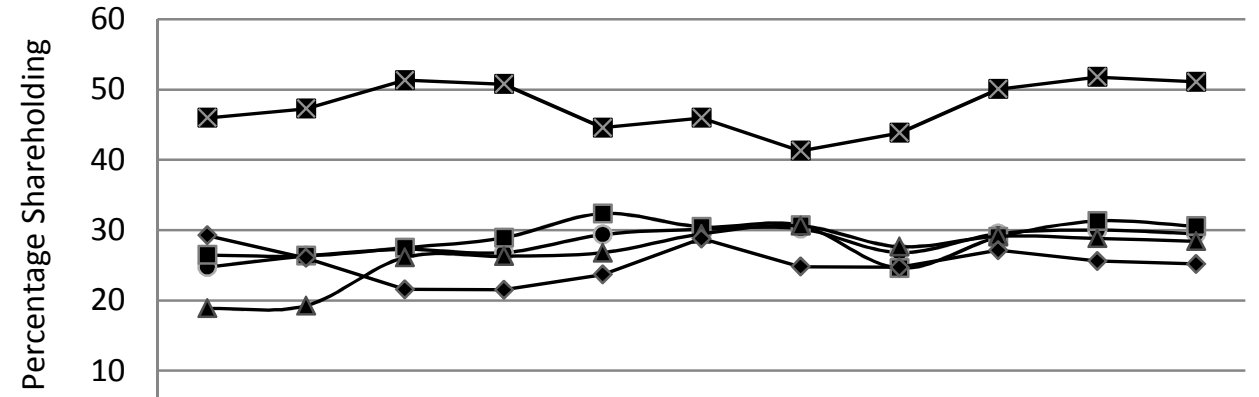

0

\begin{tabular}{|l|l|l|l|l|l|l|l|l|l|l|}
2001 & 2002 & 2003 & 2004 & 2005 & 2006 & 2007 & 2008 & 2009 & 2010 & 2011 \\
\hline
\end{tabular}

-๑-All Companies

\begin{tabular}{|l|l|l|l|l|l|l|l|l|l|l|}
24.75 & 26.34 & 27.27 & 26.80 & 29.36 & 30.13 & 30.19 & 26.82 & 29.50 & 30.01 & 29.50 \\
\hline
\end{tabular}

-n-Domestic Private Sector 26.

$\rightarrow$ Foreign Private Sector

\begin{tabular}{|l|l|l|l|l|l|l|l|l|l|l|}
26.46 & 26.34 & 27.50 & 28.93 & 32.36 & 30.47 & 30.69 & 24.60 & 29.01 & 31.29 & 30.57 \\
\hline
\end{tabular}

$\longrightarrow$ Government Owned

\begin{tabular}{|l|l|l|l|l|l|l|l|l|l|l|}
\hline 18.86 & 19.26 & 26.13 & 26.29 & 26.80 & 29.47 & 30.62 & 27.64 & 29.13 & 28.84 & 28.42 \\
\hline
\end{tabular}

Management Controlled

\begin{tabular}{|l|l|l|l|l|l|l|l|l|l|l|}
29.24 & 26.04 & 21.58 & 21.51 & 23.67 & 28.82 & 24.79 & 24.70 & 27.15 & 25.62 & 25.20 \\
\hline
\end{tabular}

\begin{tabular}{|l|l|l|l|l|l|l|l|l|l|l|}
45.98 & 47.28 & 51.33 & 50.77 & 44.60 & 45.98 & 41.30 & 43.83 & 50.06 & 51.80 & 51.09 \\
\hline
\end{tabular}

Exhibit AC-13 CNX-100-Set A-Mean Non Institutional Ownership Trends, 2001-2011 
CNX-100-Set A-Mean Non Institutional Ownership Trends, 2001-2011 (N=100)

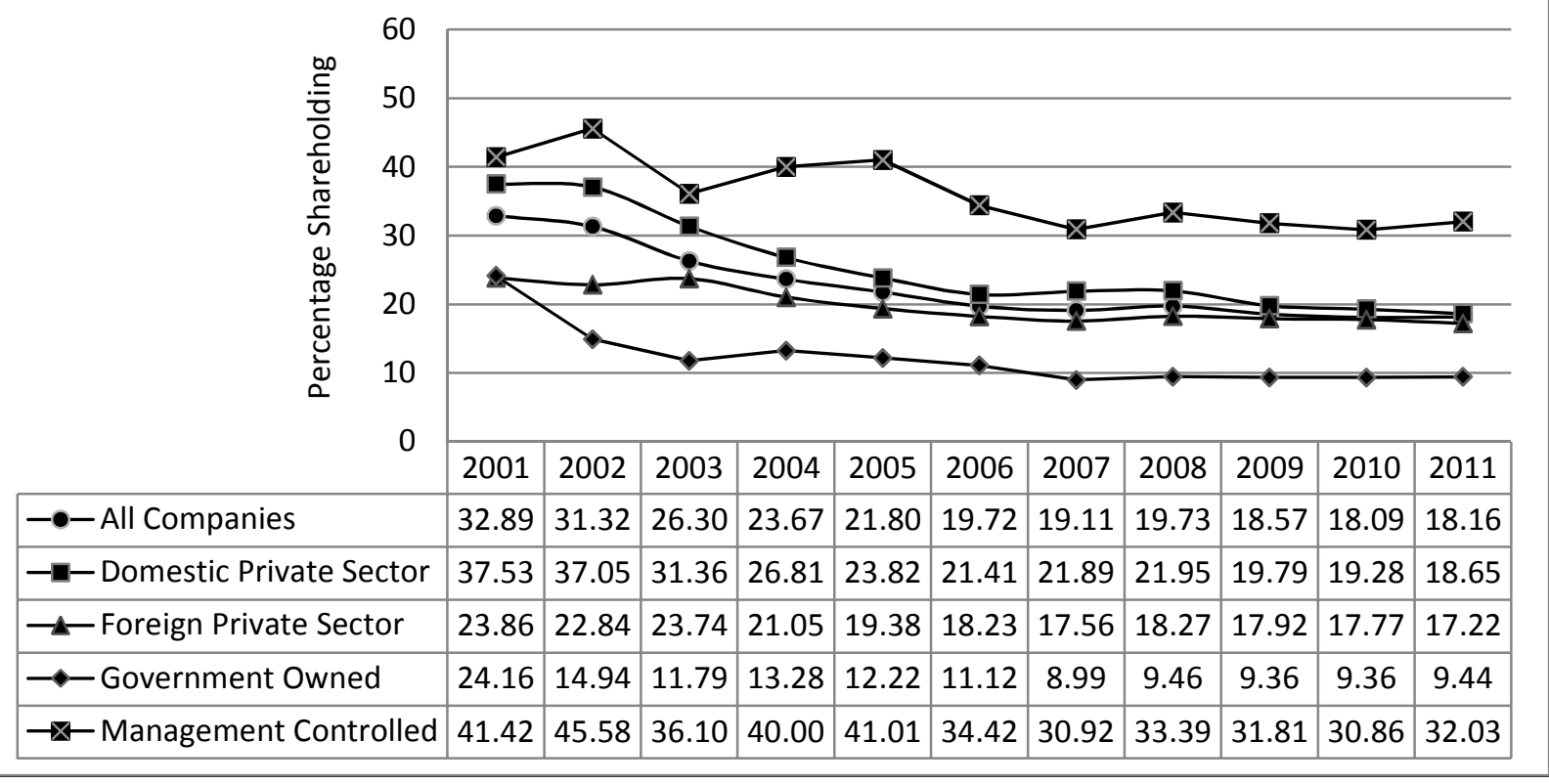

Exhibit AC-14 CNX-100-Set A-Median Non Institutional Ownership Trends, 2001-2011

CNX-100-Set A-Median Non Institutional Ownership Trends, 2001-2011 (N=100)

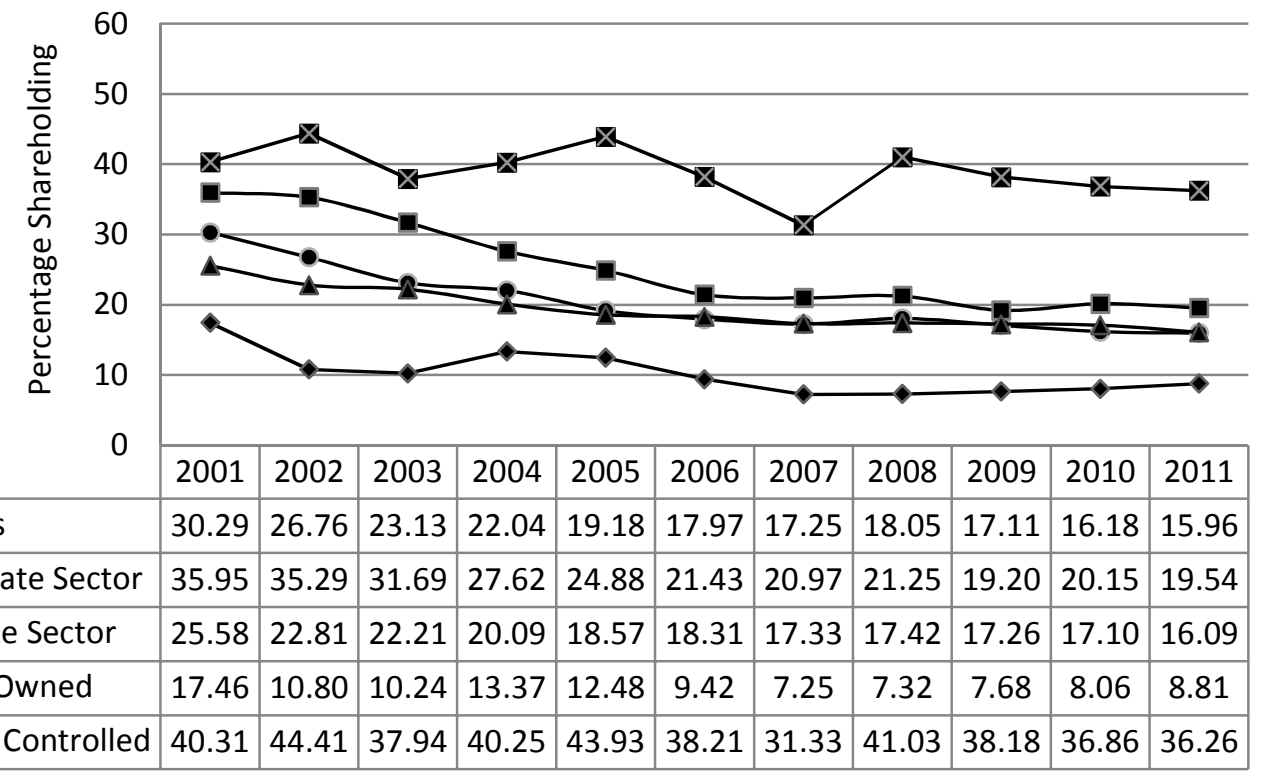


Exhibit BN-1 NIFTY-Set B-Mean Ownership Trends, 2001-2011

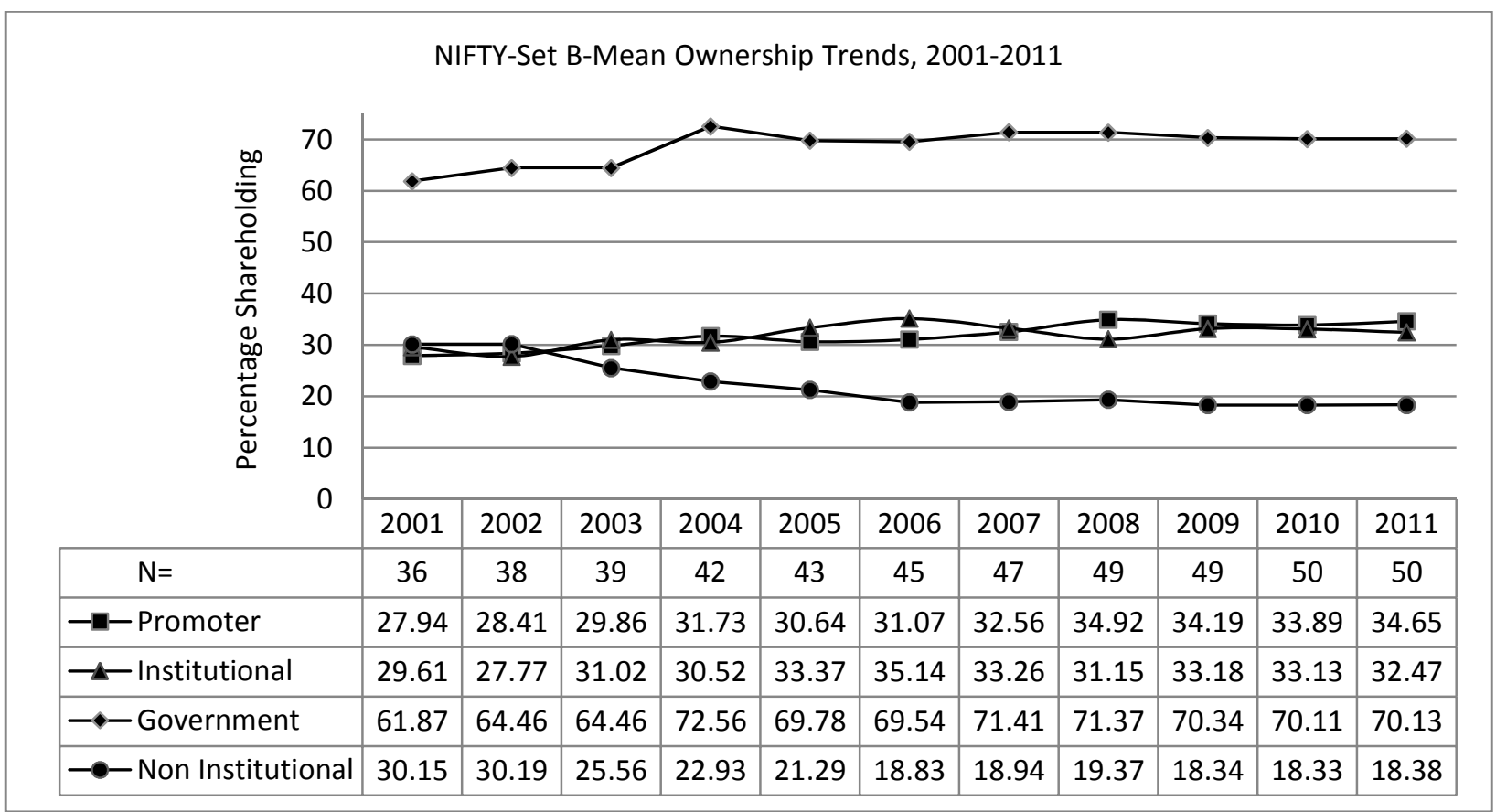

Exhibit BN-2 NIFTY-Set B-Median Ownership Trends, 2001-2011

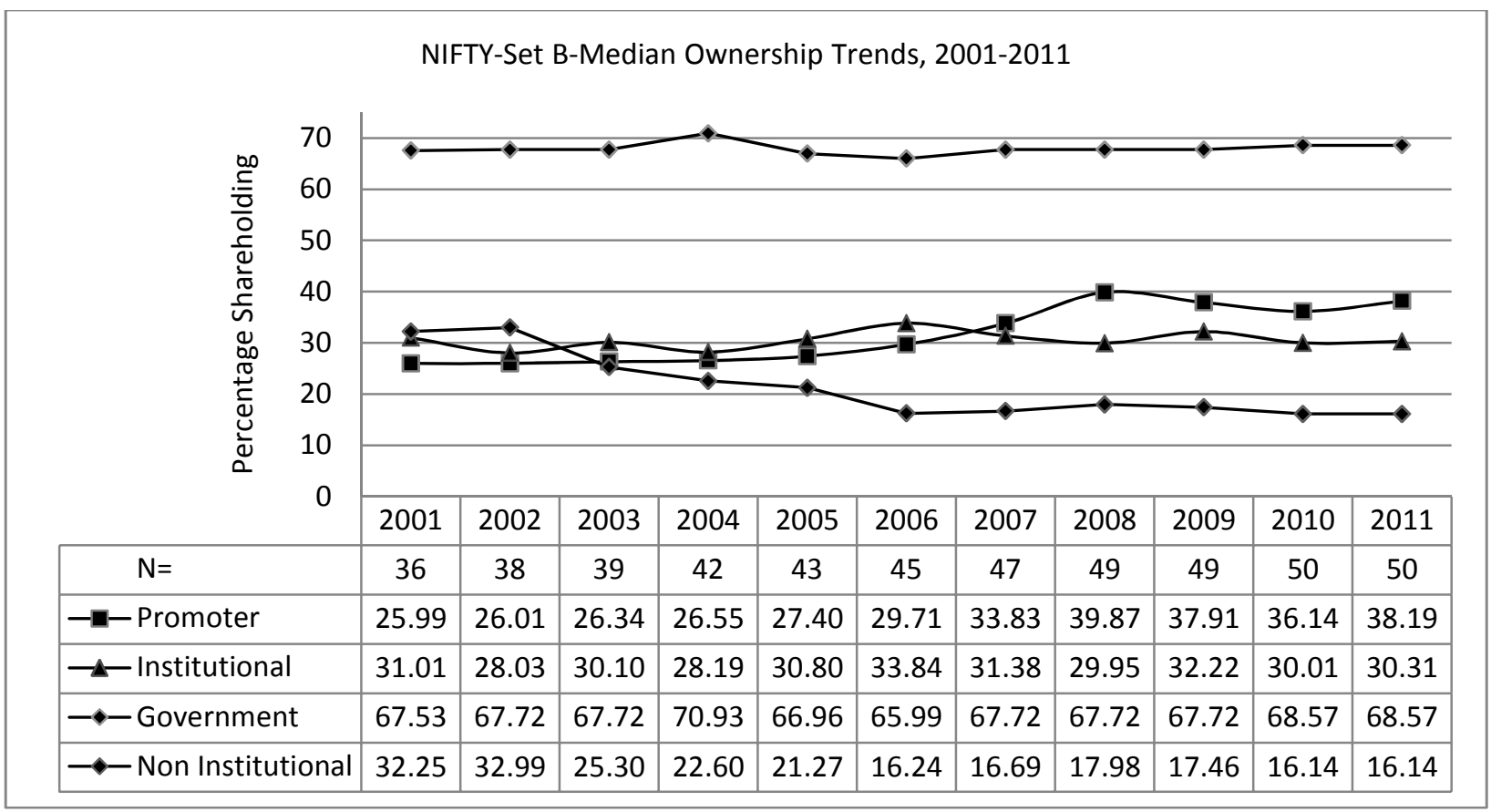


Exhibit BN-3 NIFTY-Set B-Domestic Pvt. Sector Companies-Mean Ownership Trends, 20012011

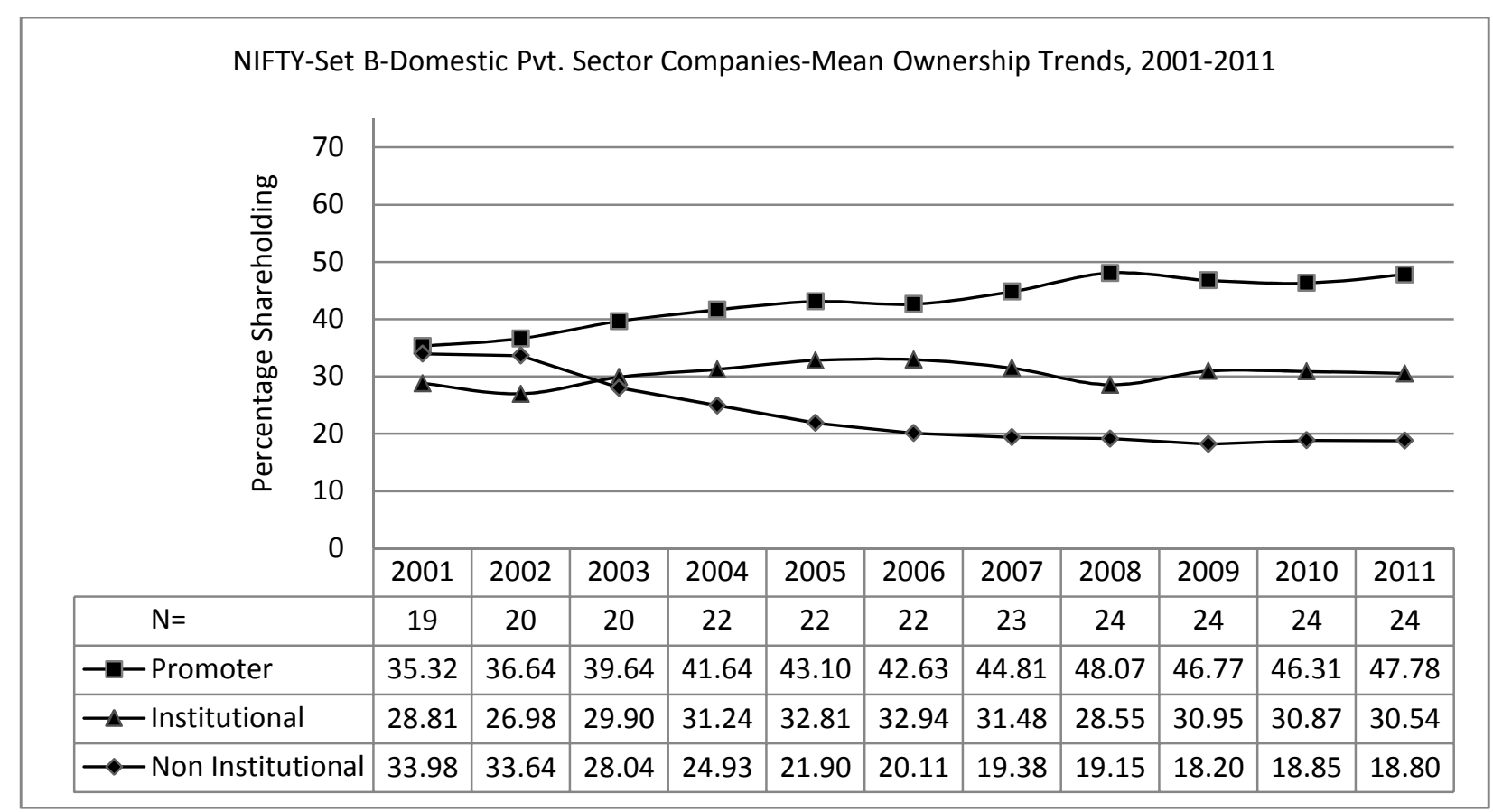

Exhibit BN-4 NIFTY-Set B-Domestic Pvt. Sector Companies-Median Ownership Trends, 20012011 
NIFTY-Set B-Domestic Pvt. Sector Companies-Median Ownership Trends, 2001-2011

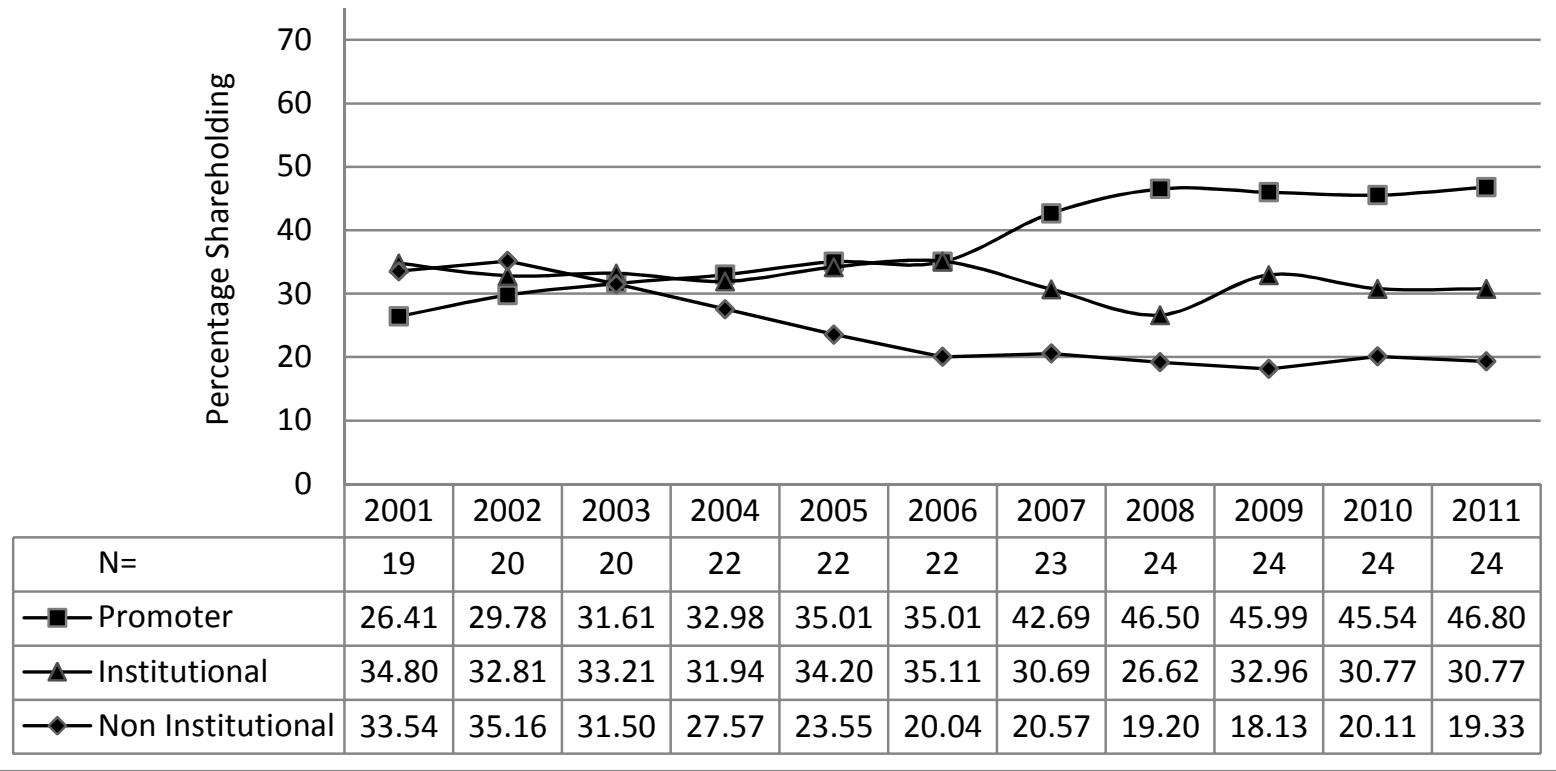

Exhibit BN-5 NIFTY-Set B-Foreign Pvt. Sector Companies-Mean Ownership Trends, 20012011

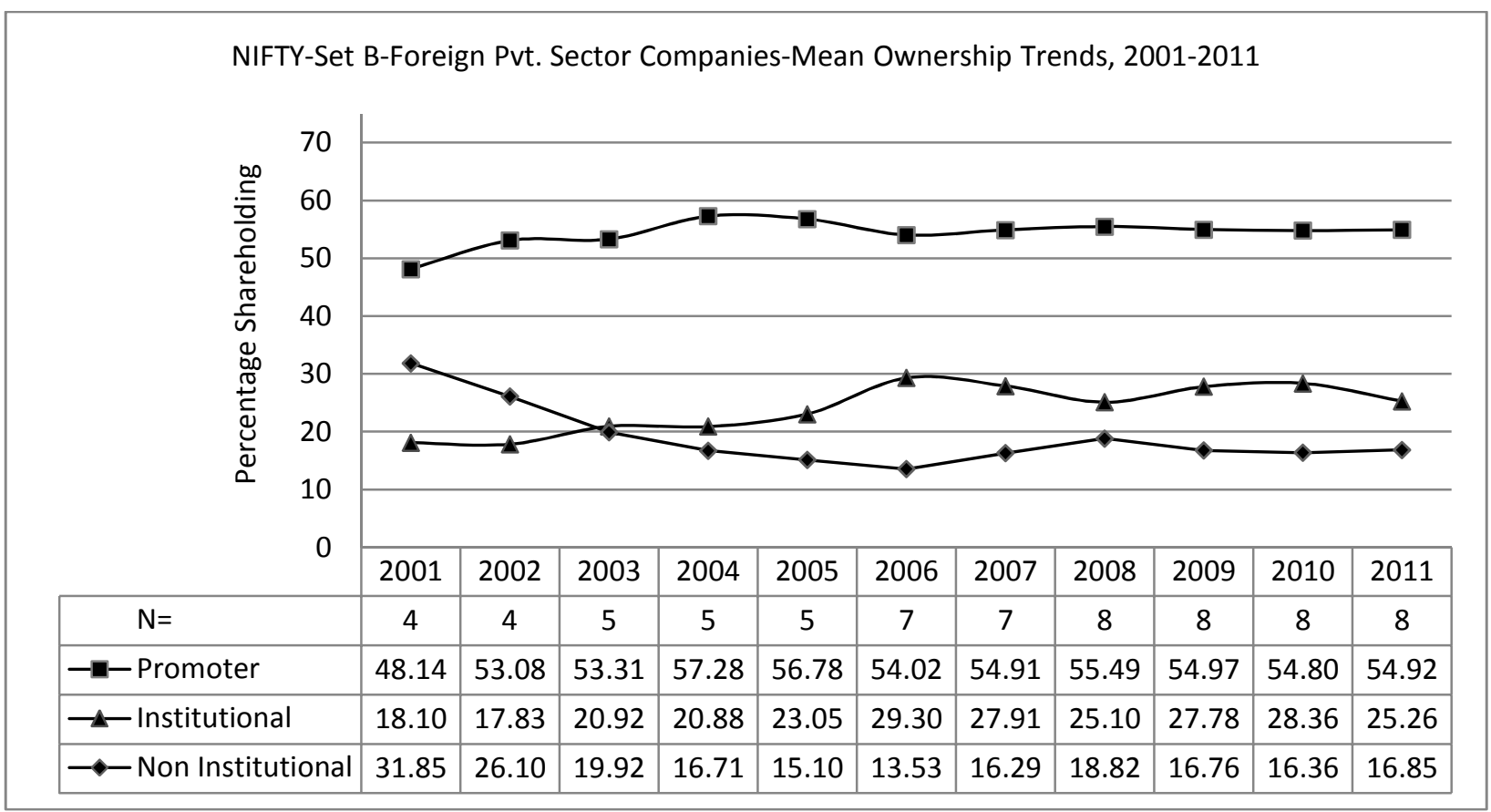

Exhibit BN-6 NIFTY-Set B-Foreign Pvt. Sector Companies-Median Ownership Trends, 20012011 
NIFTY-Set B-Foreign Pvt. Sector Companies-Median Ownership Trends, 2001-2011

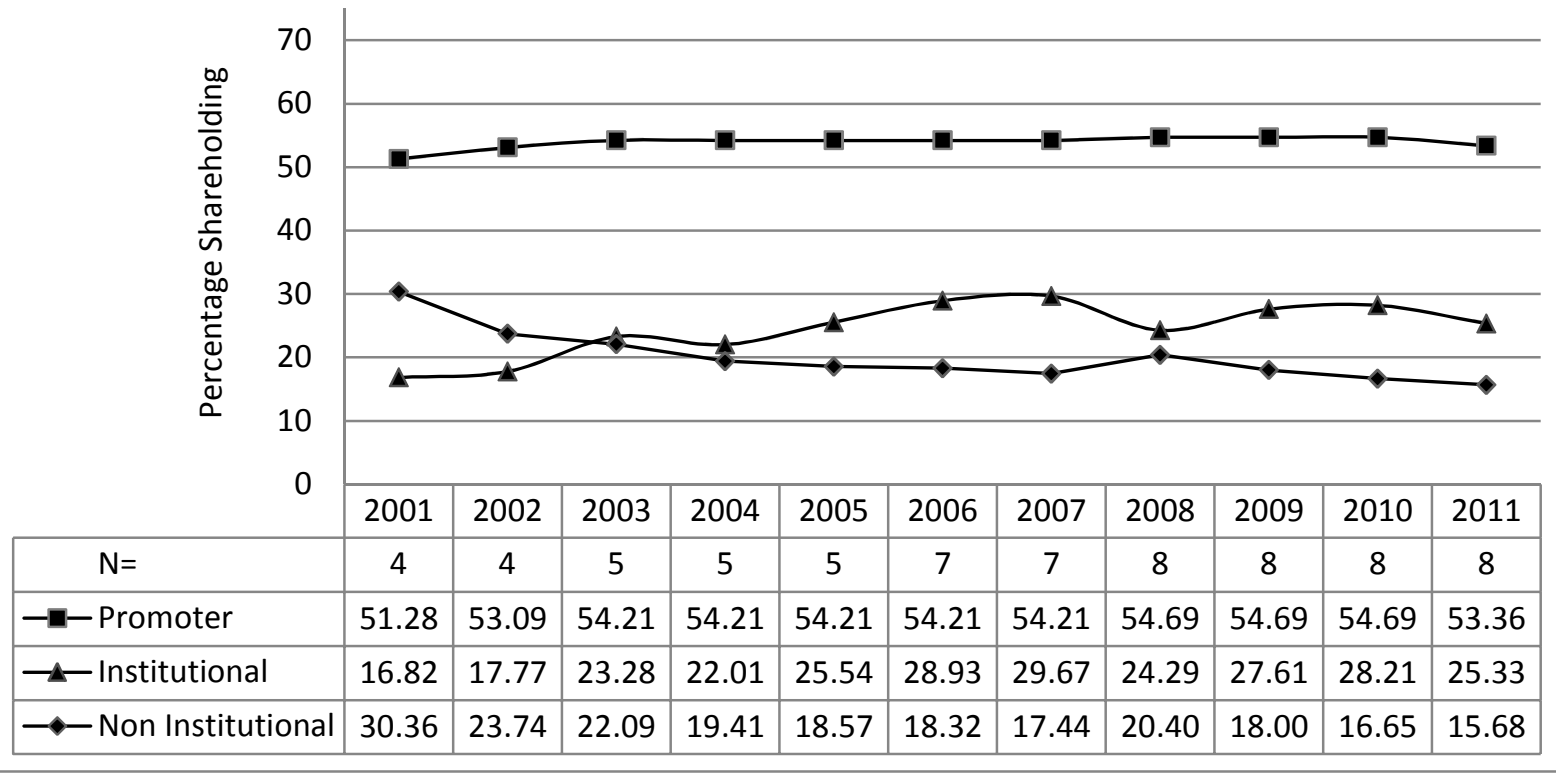

Exhibit BN-7 NIFTY-Set B-Government Owned Companies-Mean Ownership Trends, 20012011

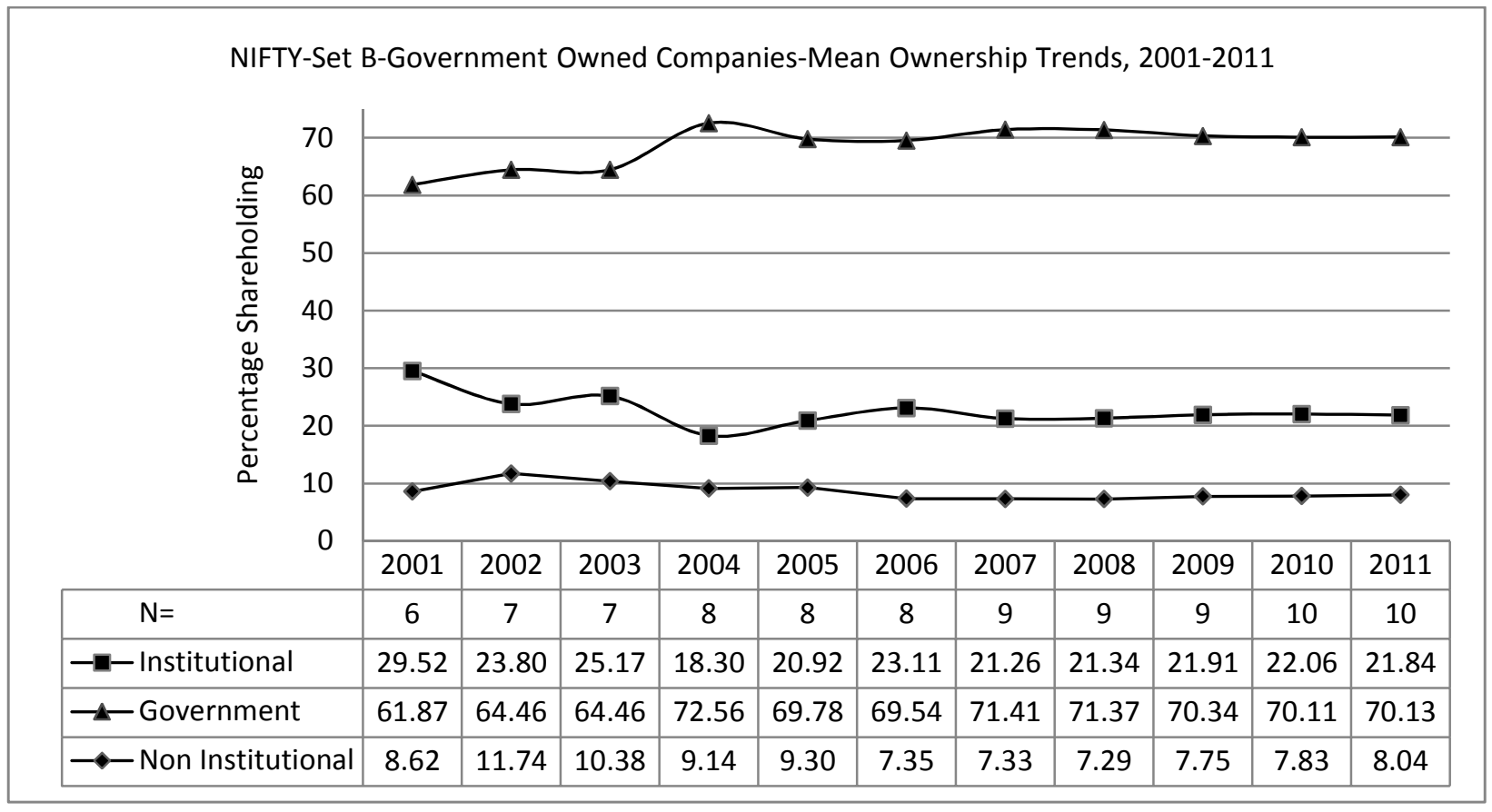


Exhibit BN-8 NIFTY-Set B-Government Owned Companies-Median Ownership Trends, 20012011

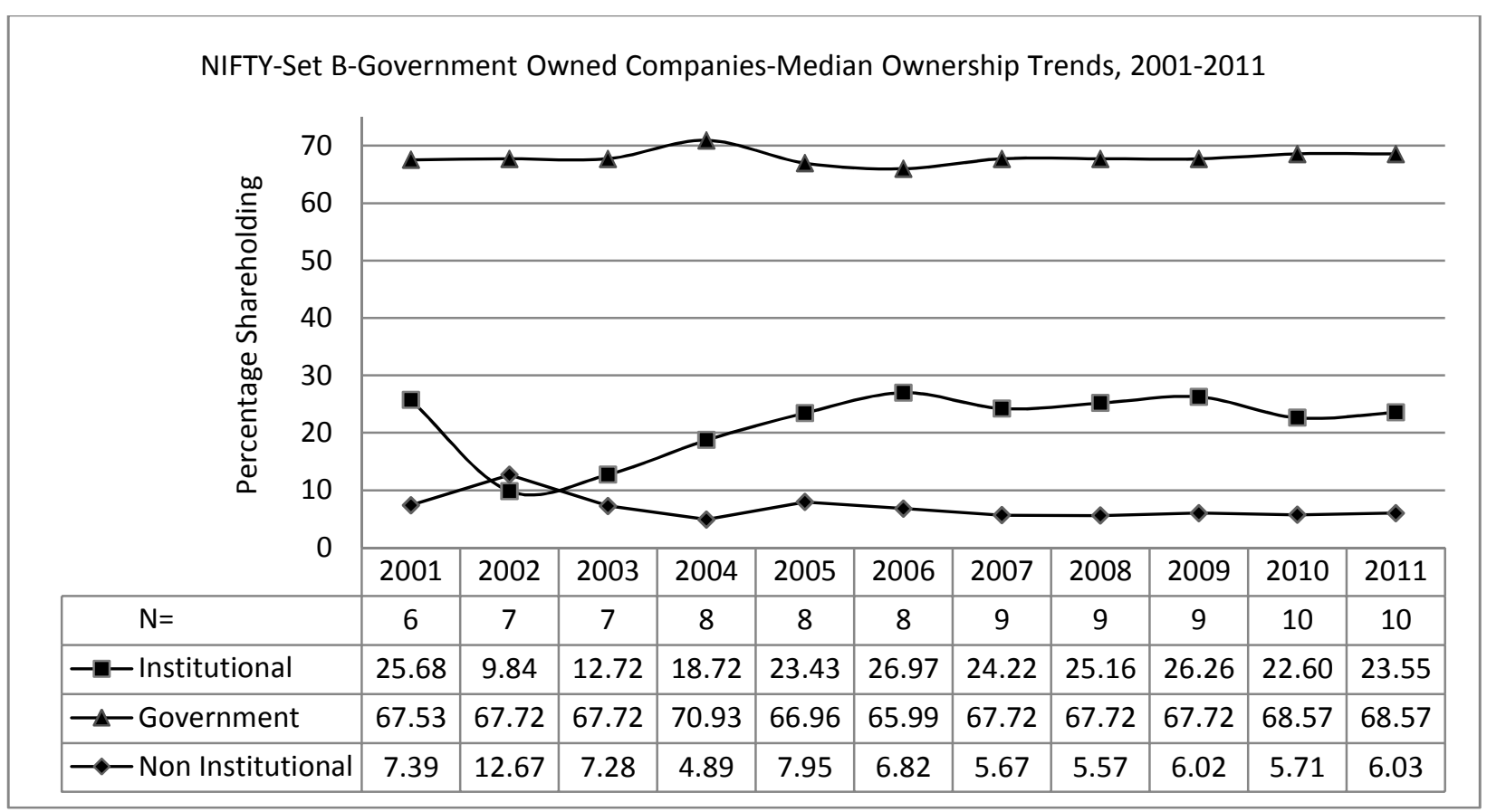

Exhibit BN-9 NIFTY-Set B-Management Controlled Companies-Mean Ownership Trends, 2001-2011 
NIFTY-Set B-Management Controlled Companies-Mean Ownership Trends, 2001-2011

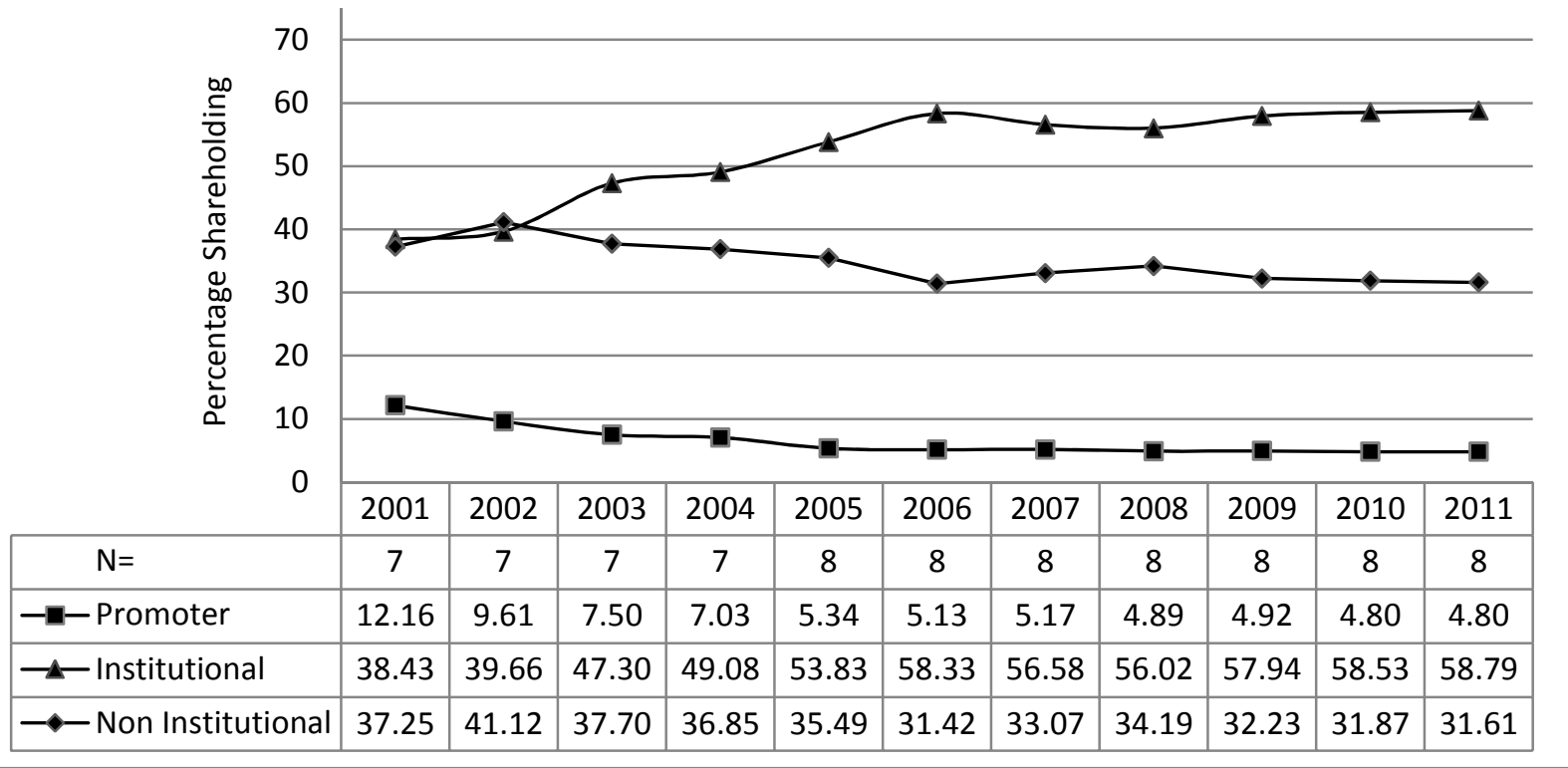

Exhibit BN-10 NIFTY-Set B-Management Controlled Companies-Median Ownership Trends, 2001-2011

NIFTY-Set B-Management Controlled Companies-Median Ownership Trends, 2001-2011

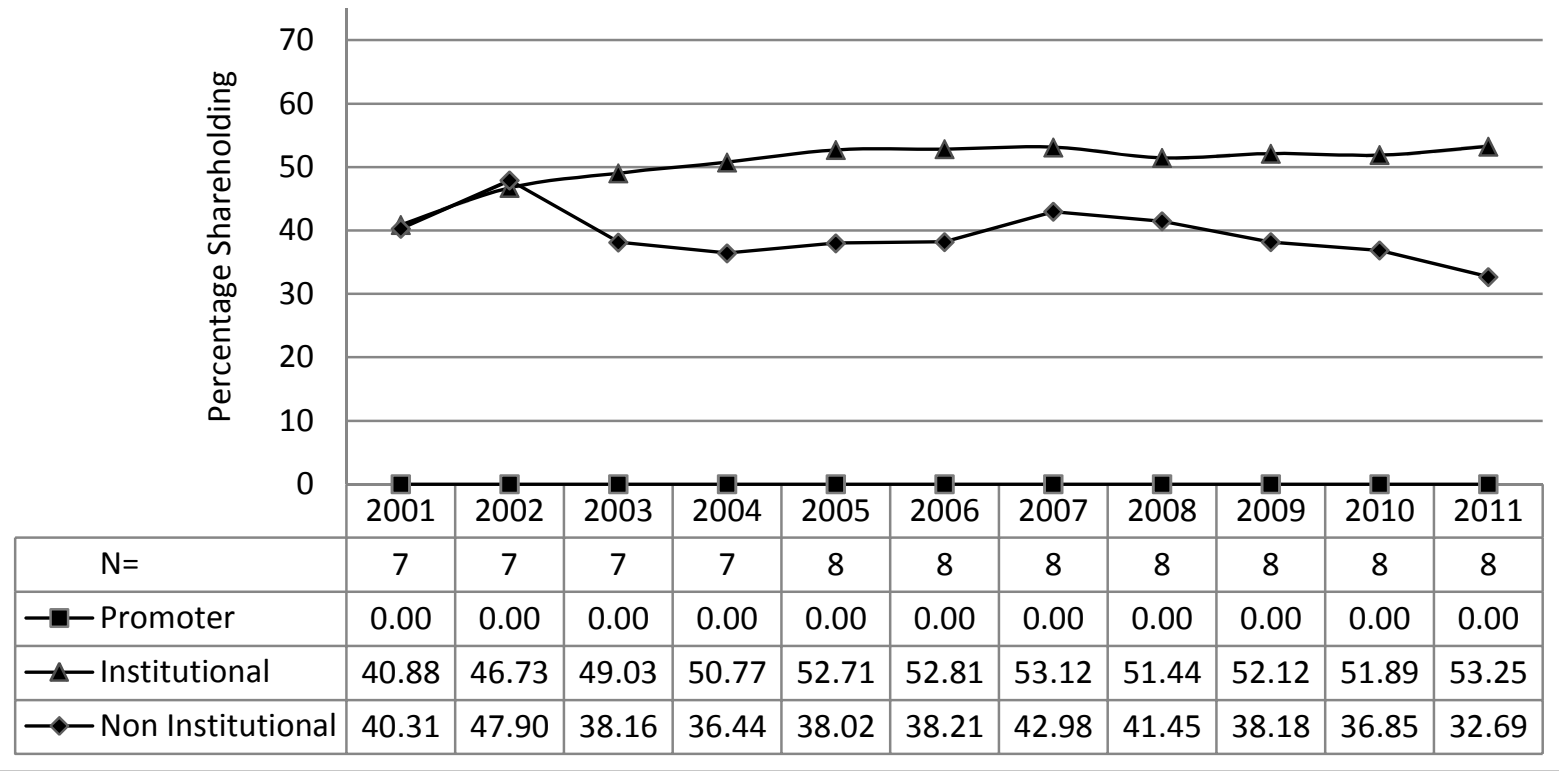

Exhibit BN-11 NIFTY-Set B-Mean Institutional Ownership Trends, 2001-2011 
NIFTY-Set B-Mean Institutional Ownership Trends, 2001-2011

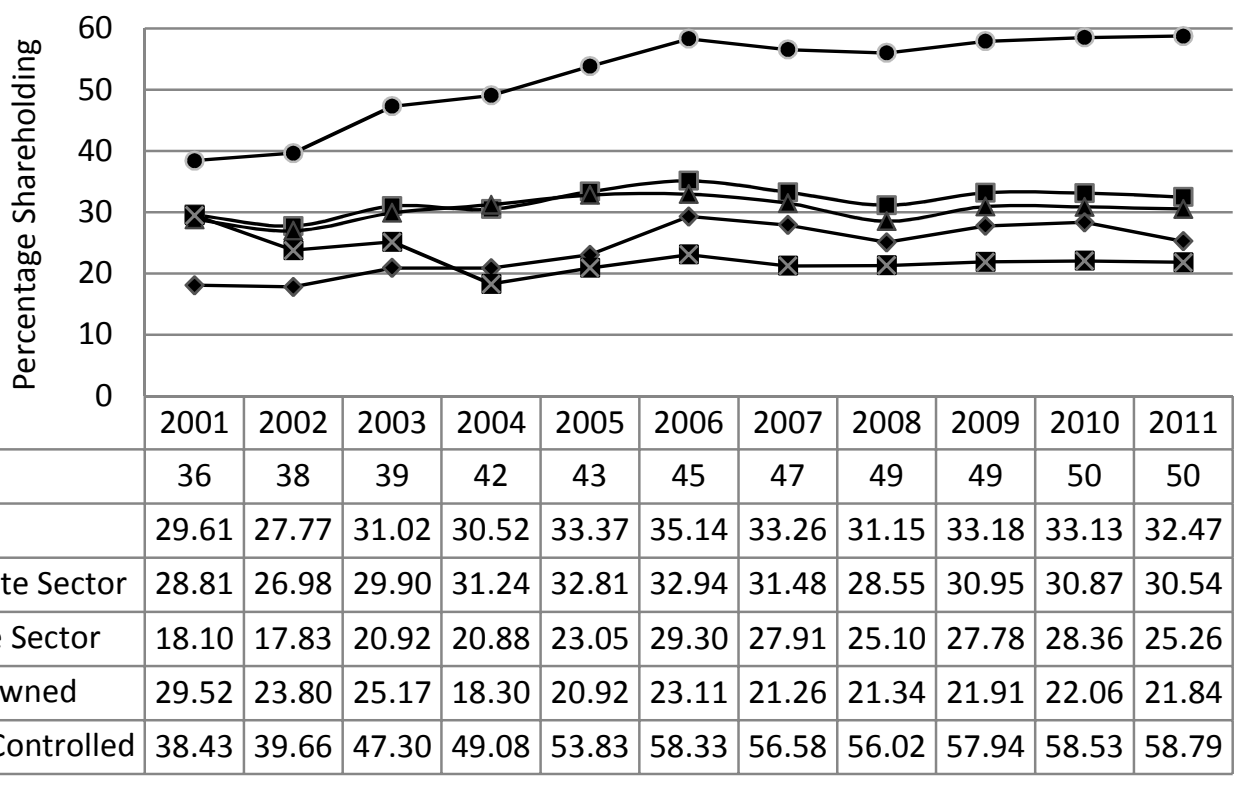

Exhibit BN-12 NIFTY-Set B-Median Institutional Ownership Trends, 2001-2011

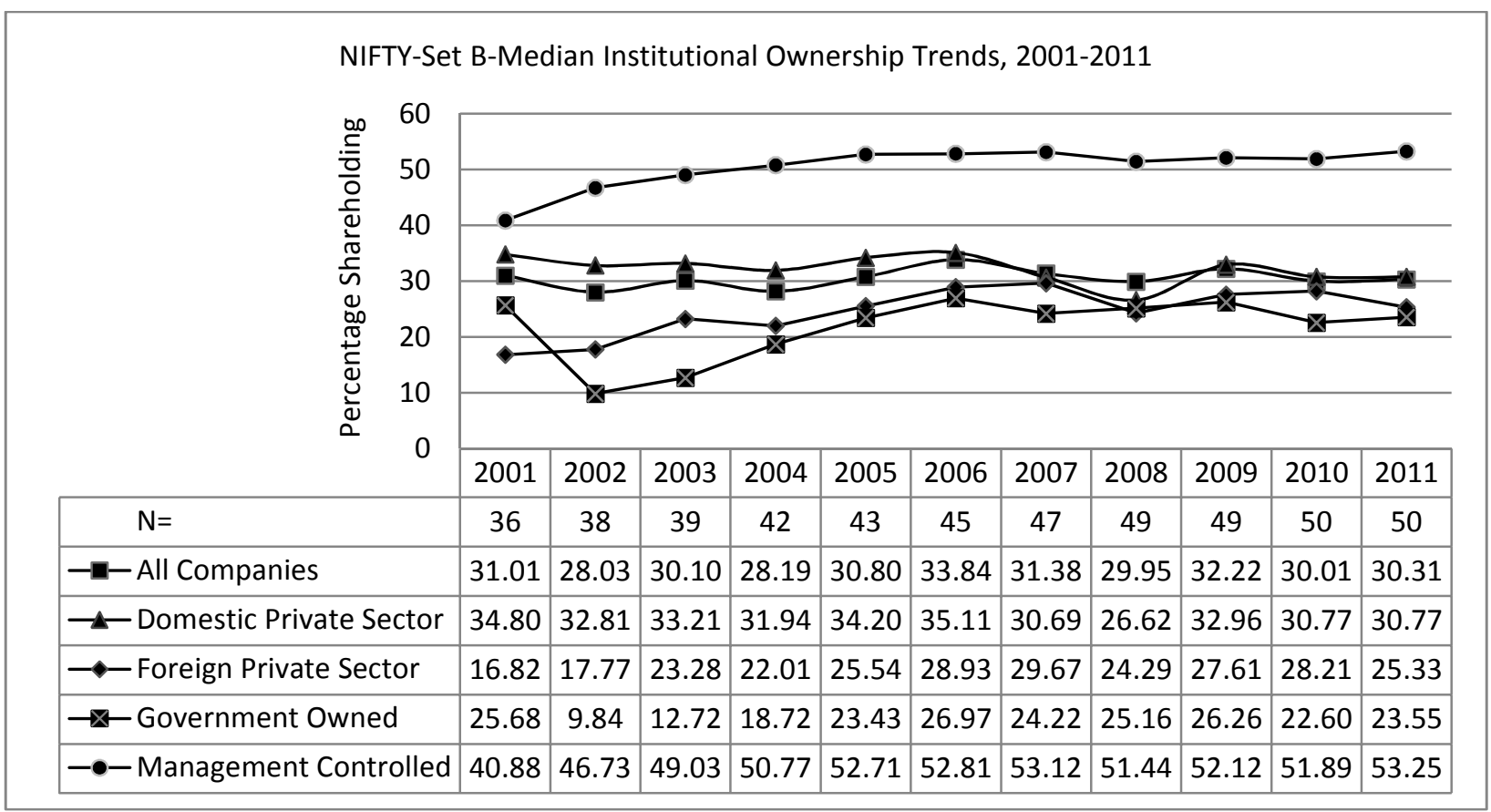


Exhibit BN-13 NIFTY-Set B-Mean Non Institutional Ownership Trends, 2001-2011

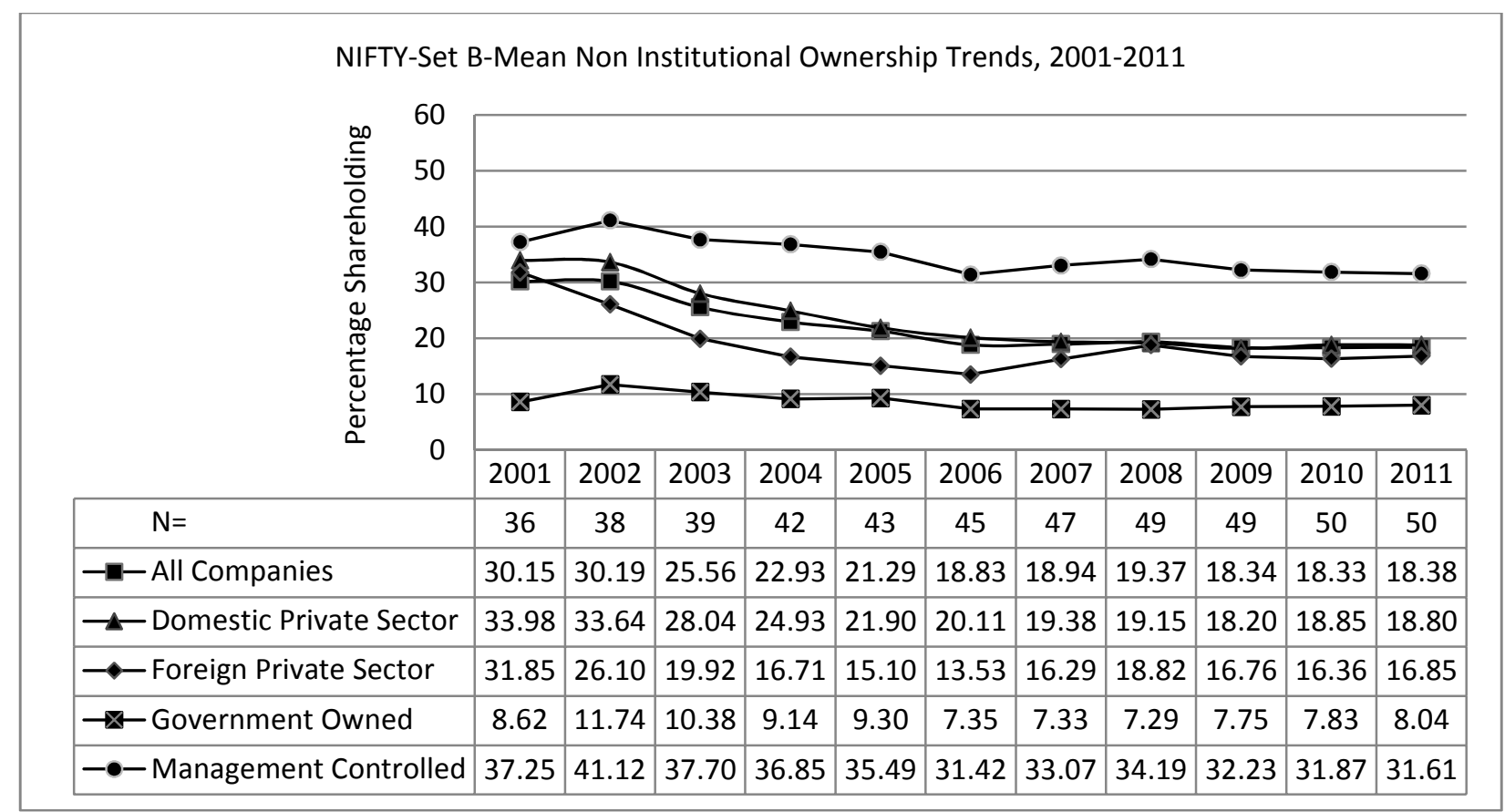

Exhibit BN-14 NIFTY-Set B-Median Non Institutional Ownership Trends, 2001-2011

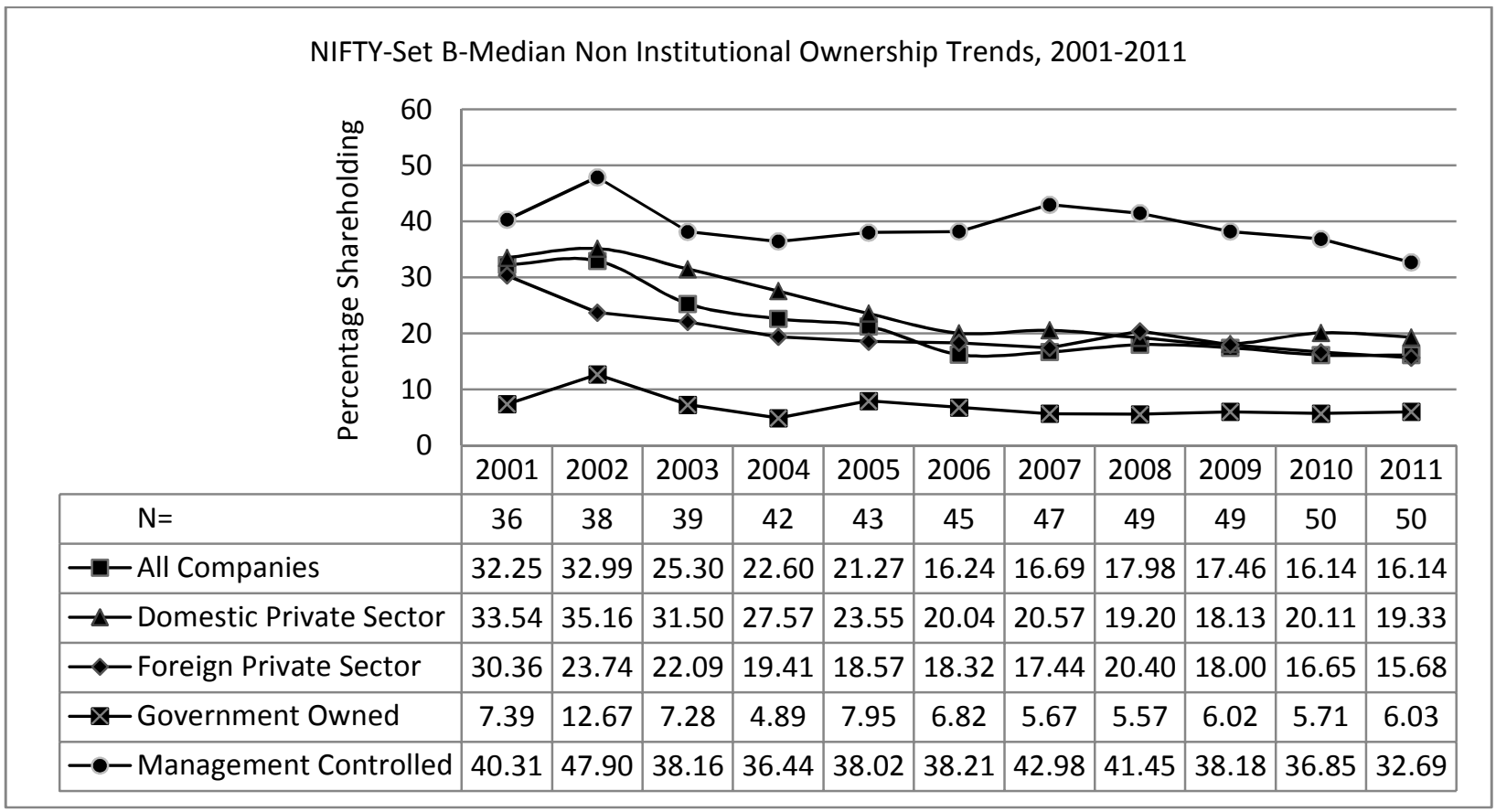


Exhibit BJ-1 JUNIOR NIFTY-Set B-Mean Ownership Trends, 2001-2011

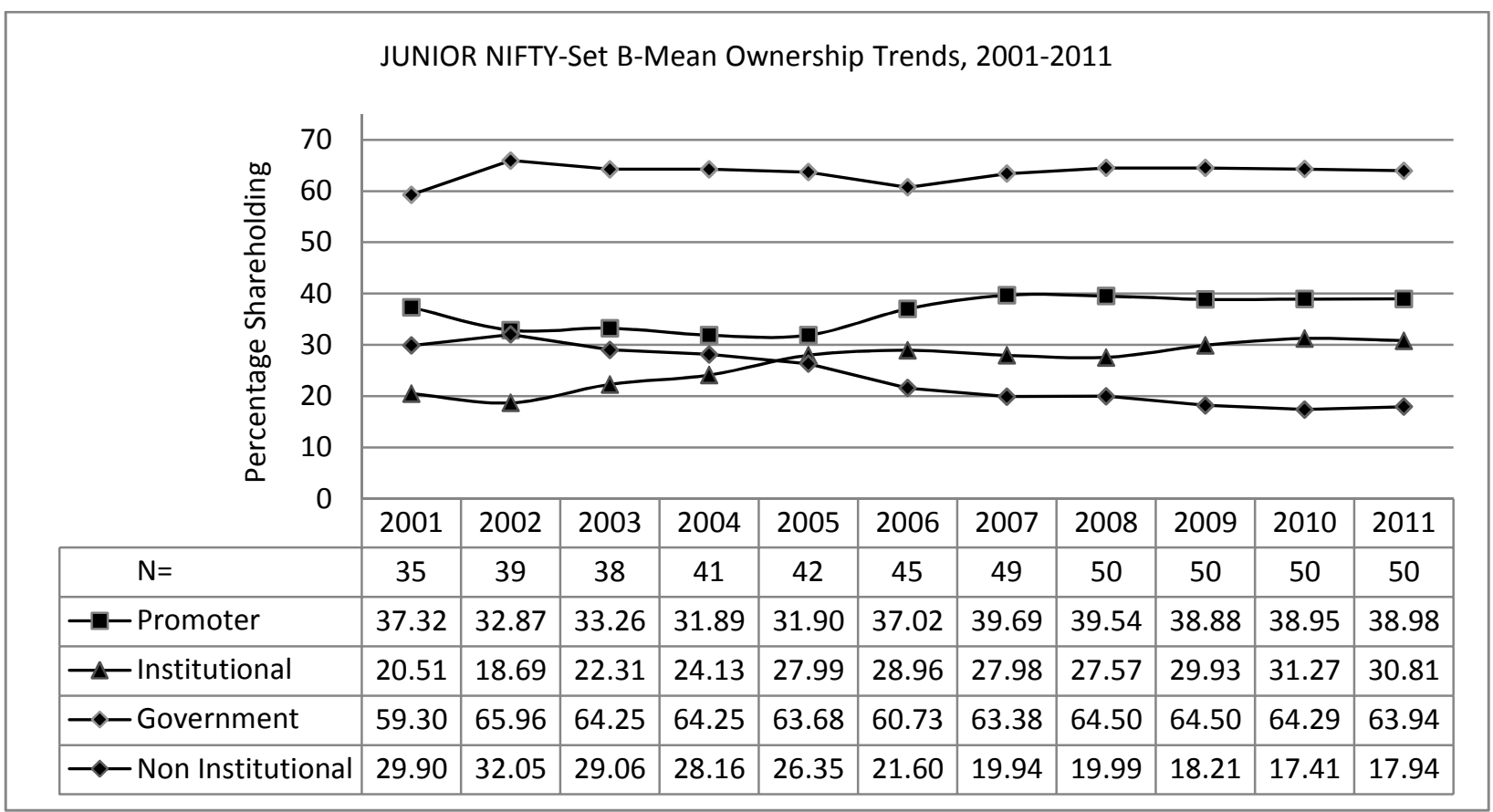

Exhibit BJ-2 JUNIOR NIFTY-Set B-Median Ownership Trends, 2001-2011

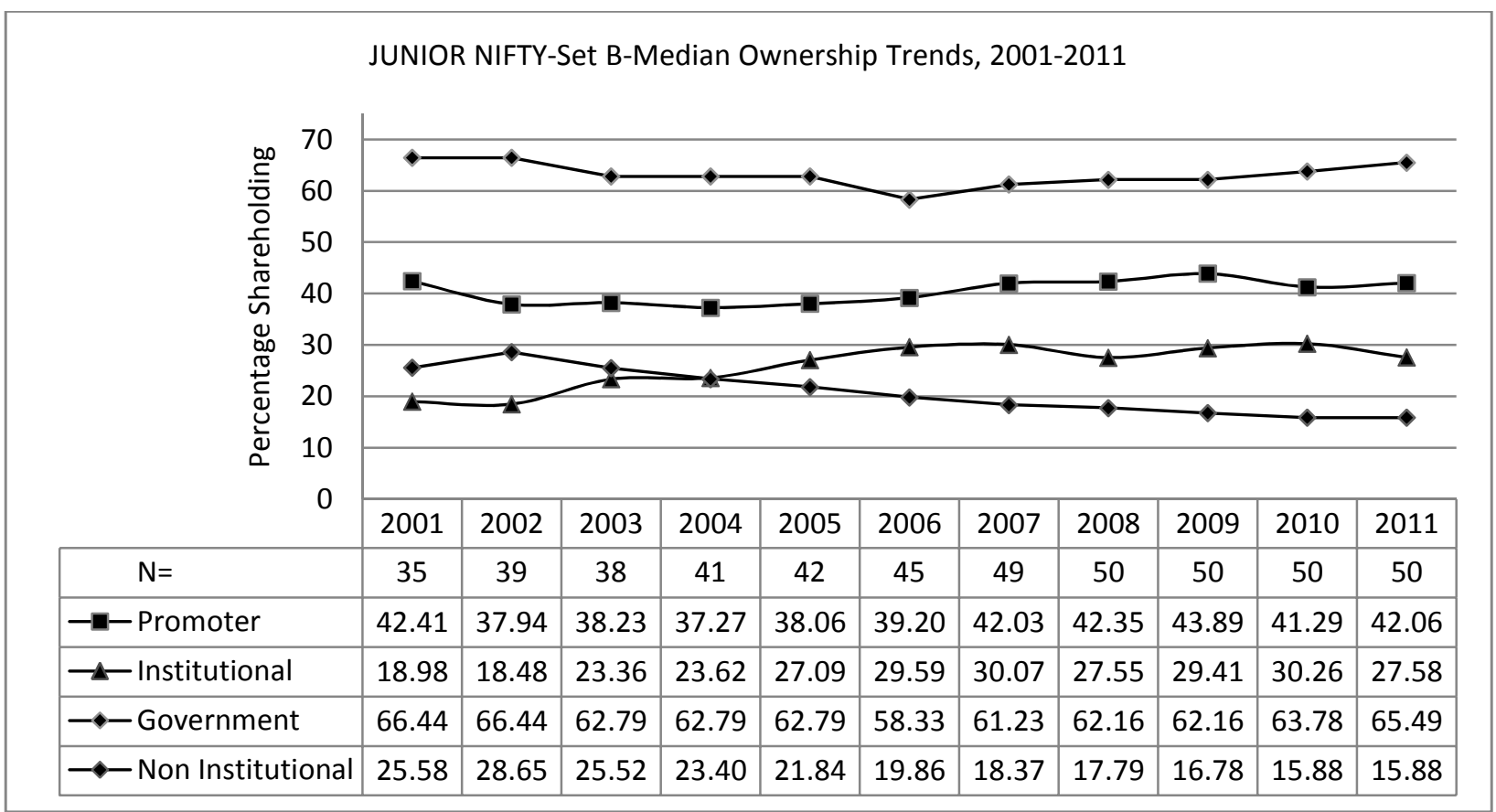


Exhibit BJ-3 JUNIOR NIFTY-Set B-Domestic Pvt. Sector Companies-Mean Ownership Trends, 2001-2011

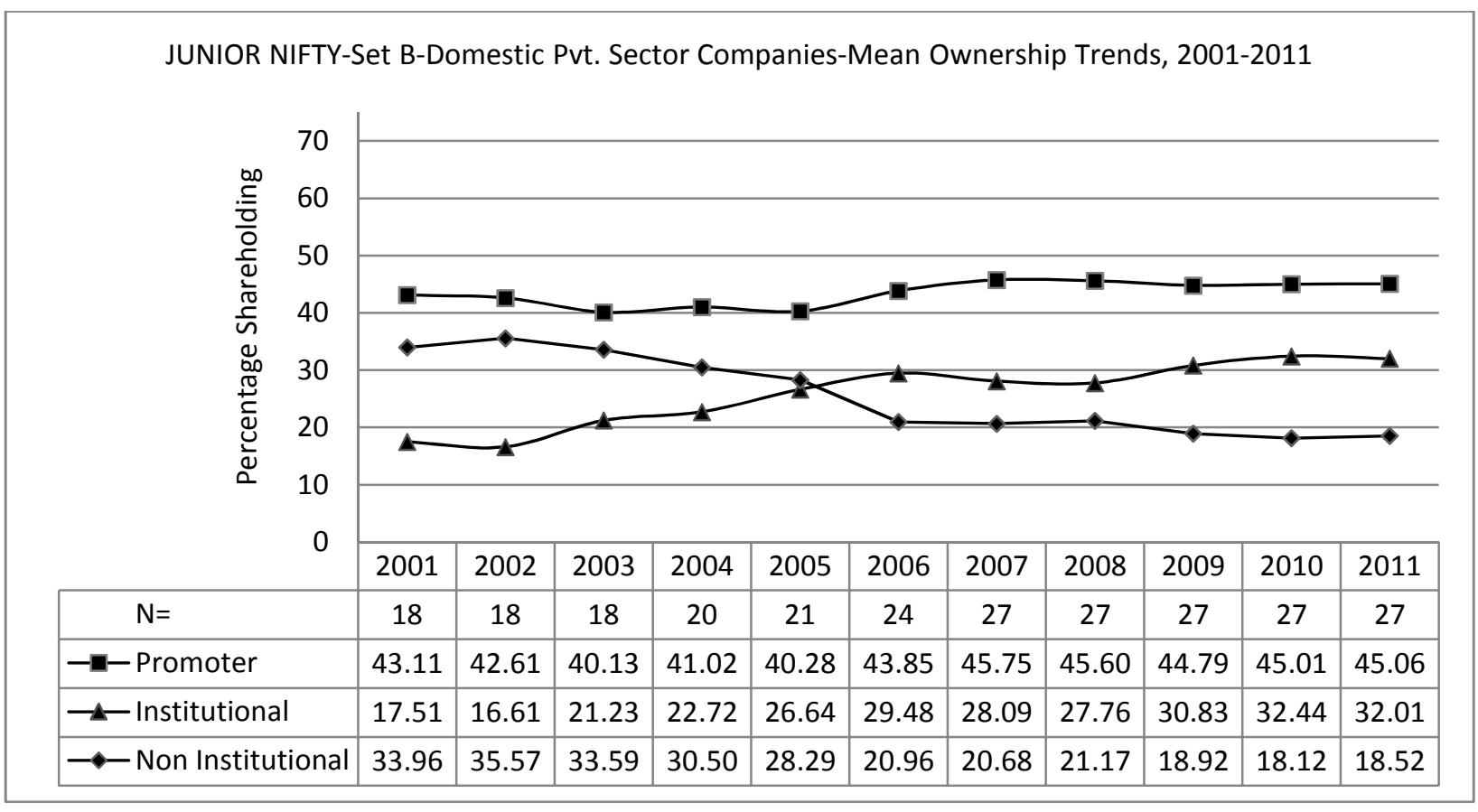

Exhibit BJ-4 JUNIOR NIFTY-Set B-Domestic Pvt. Sector Companies-Median Ownership Trends, 2001-2011 
JUNIOR NIFTY-Set B-Domestic Pvt. Sector Companies-Median Ownership Trends, 20012011

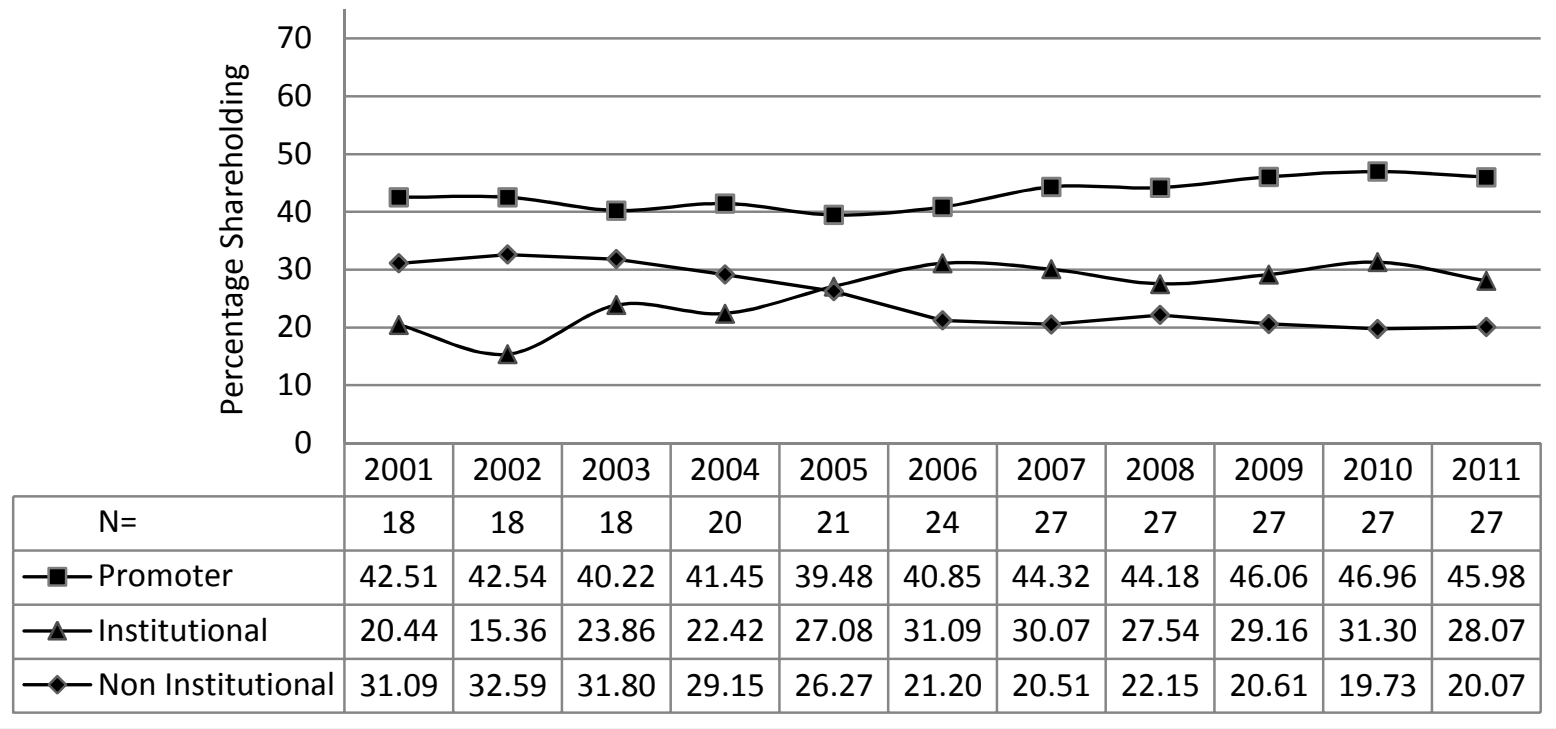

Exhibit BJ-5 JUNIOR NIFTY-Set B-Foreign Pvt. Sector Companies-Mean Ownership Trends, 2001-2011

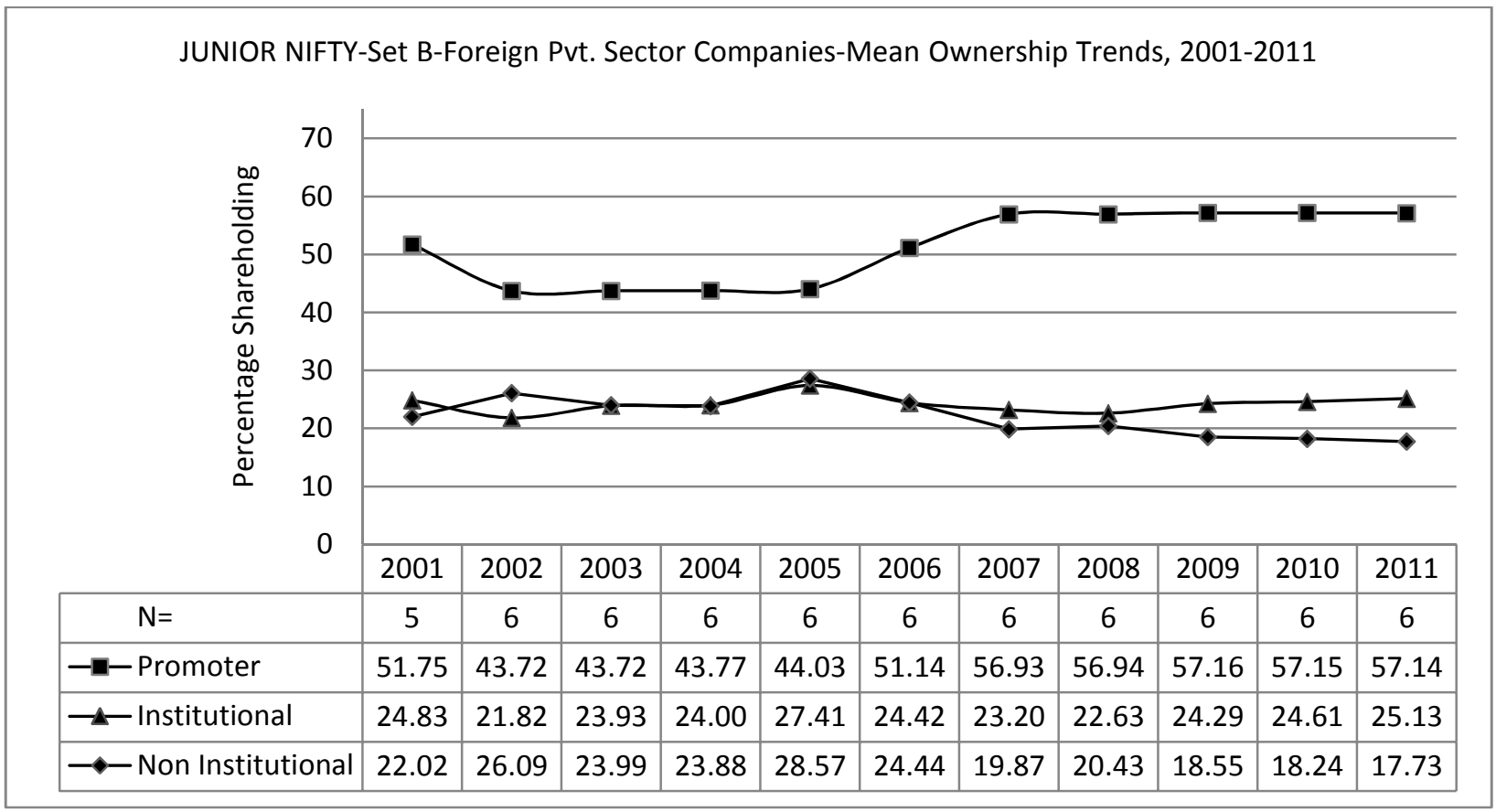

Exhibit BJ-6 JUNIOR NIFTY-Set B-Foreign Pvt. Sector Companies-Median Ownership Trends, 2001-2011 
JUNIOR NIFTY-Set B-Foreign Pvt. Sector Companies-Median Ownership Trends, 2001-2011

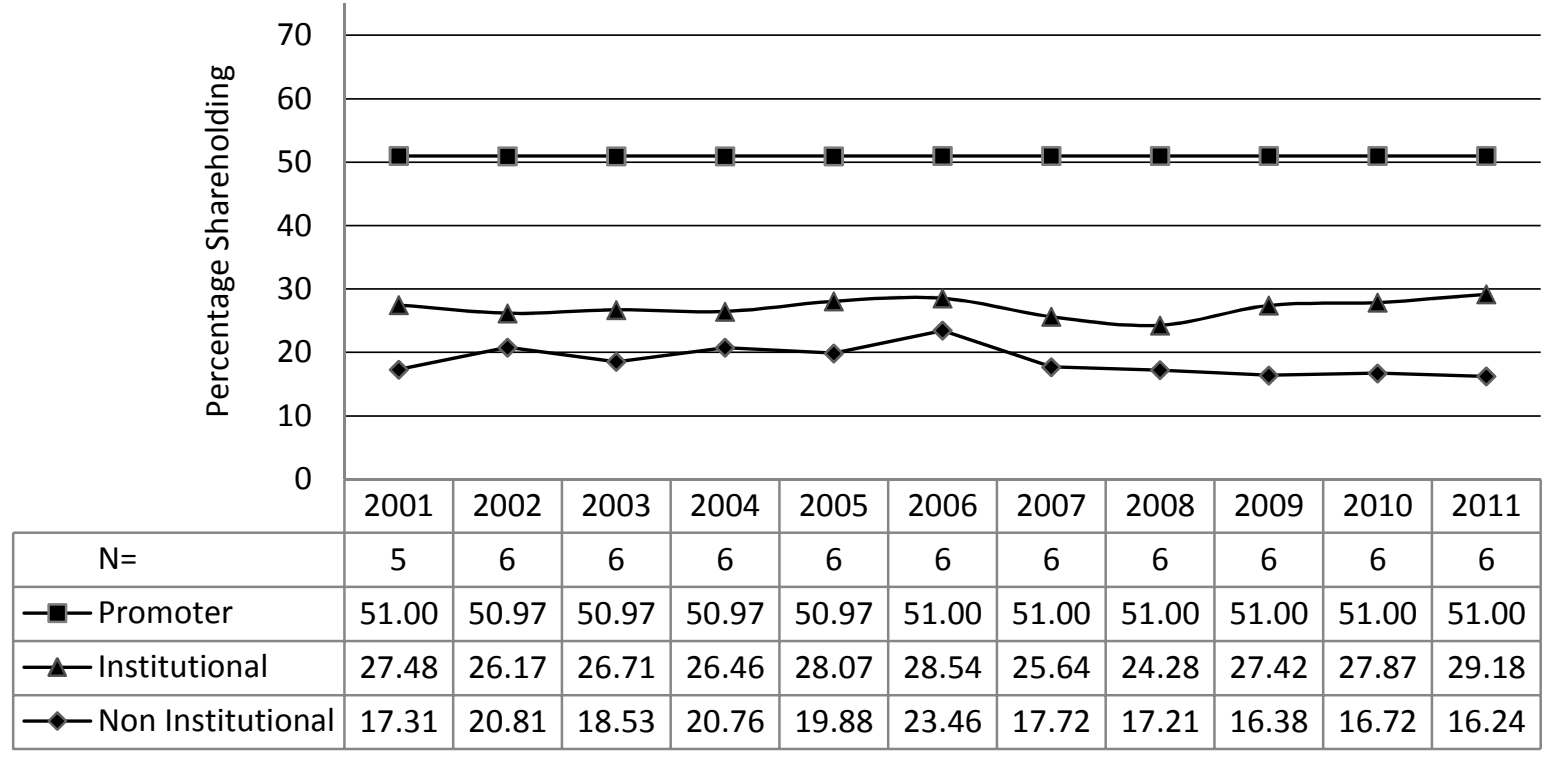

Exhibit BJ-7 JUNIOR NIFTY-Set B-Government Owned Companies-Mean Ownership Trends, 2001-2011

JUNIOR NIFTY-Set B-Government Owned Companies-Mean Ownership Trends, 2001-2011

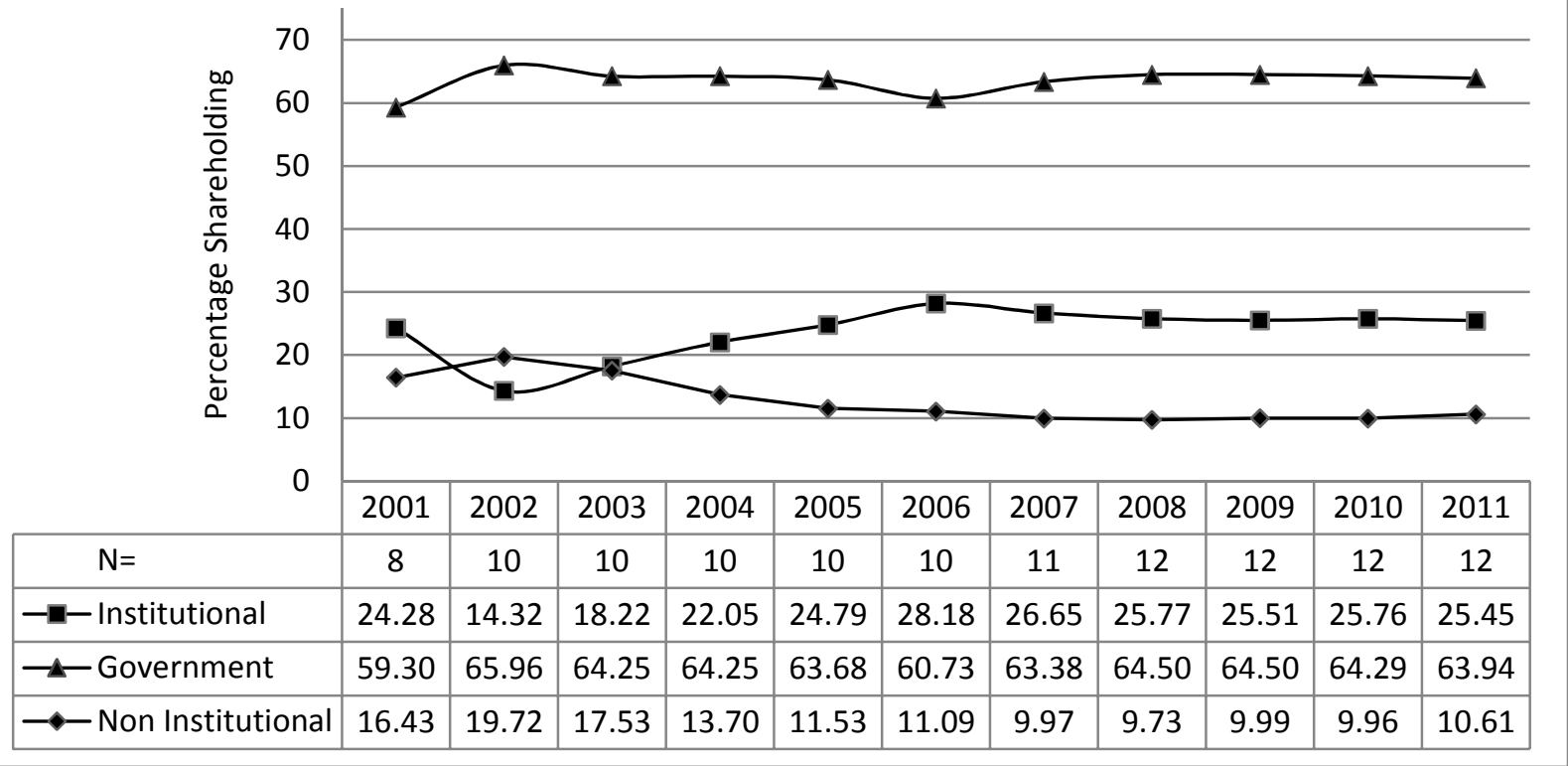


Exhibit BJ-8 JUNIOR NIFTY-Set B-Government Owned Companies-Median Ownership Trends, 2001-2011

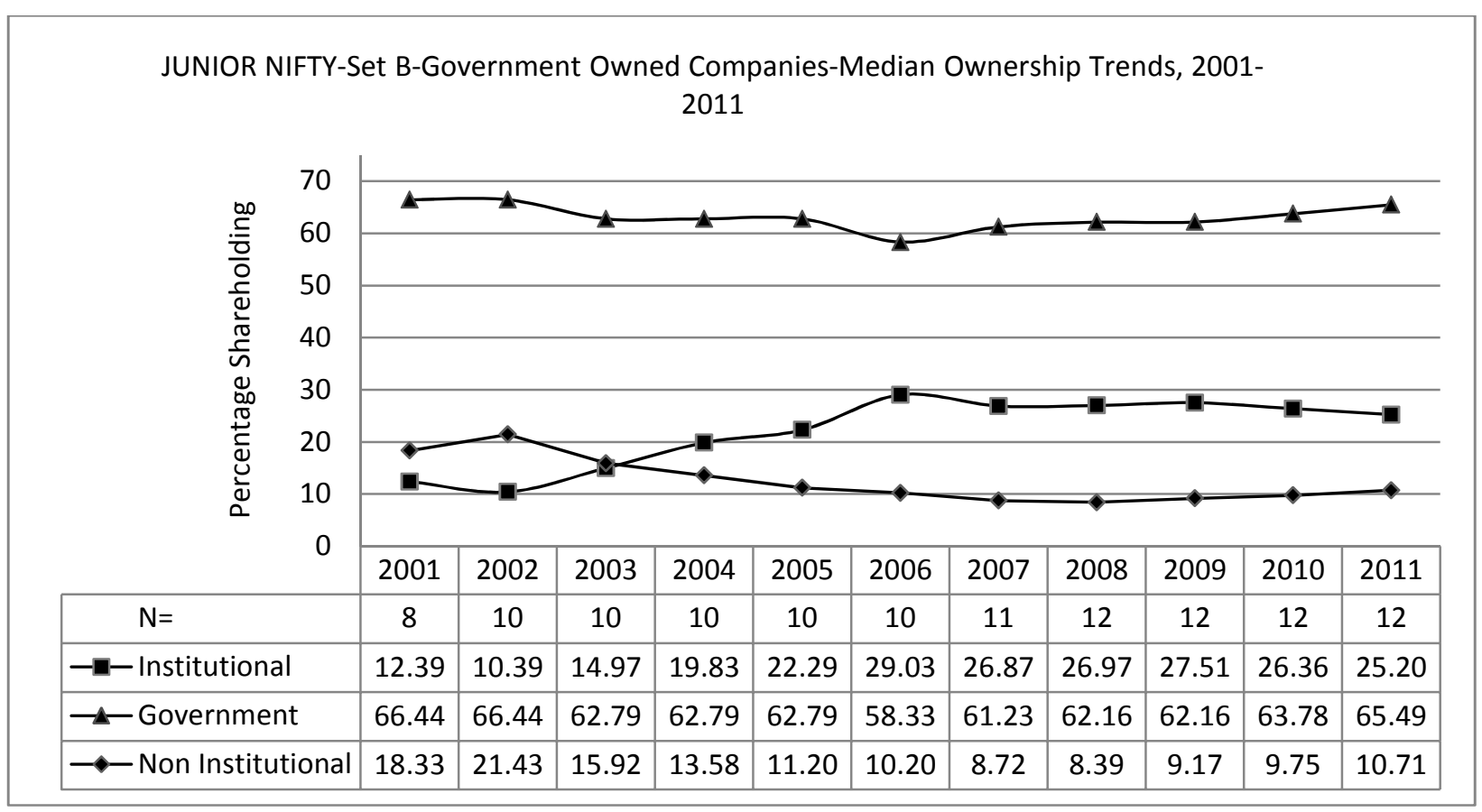

Exhibit BJ-9 JUNIOR NIFTY-Set B-Management Controlled Companies-Mean Ownership Trends, 2001-2011 
JUNIOR NIFTY-Set B-Management Controlled Companies-Mean Ownership Trends, 20012011

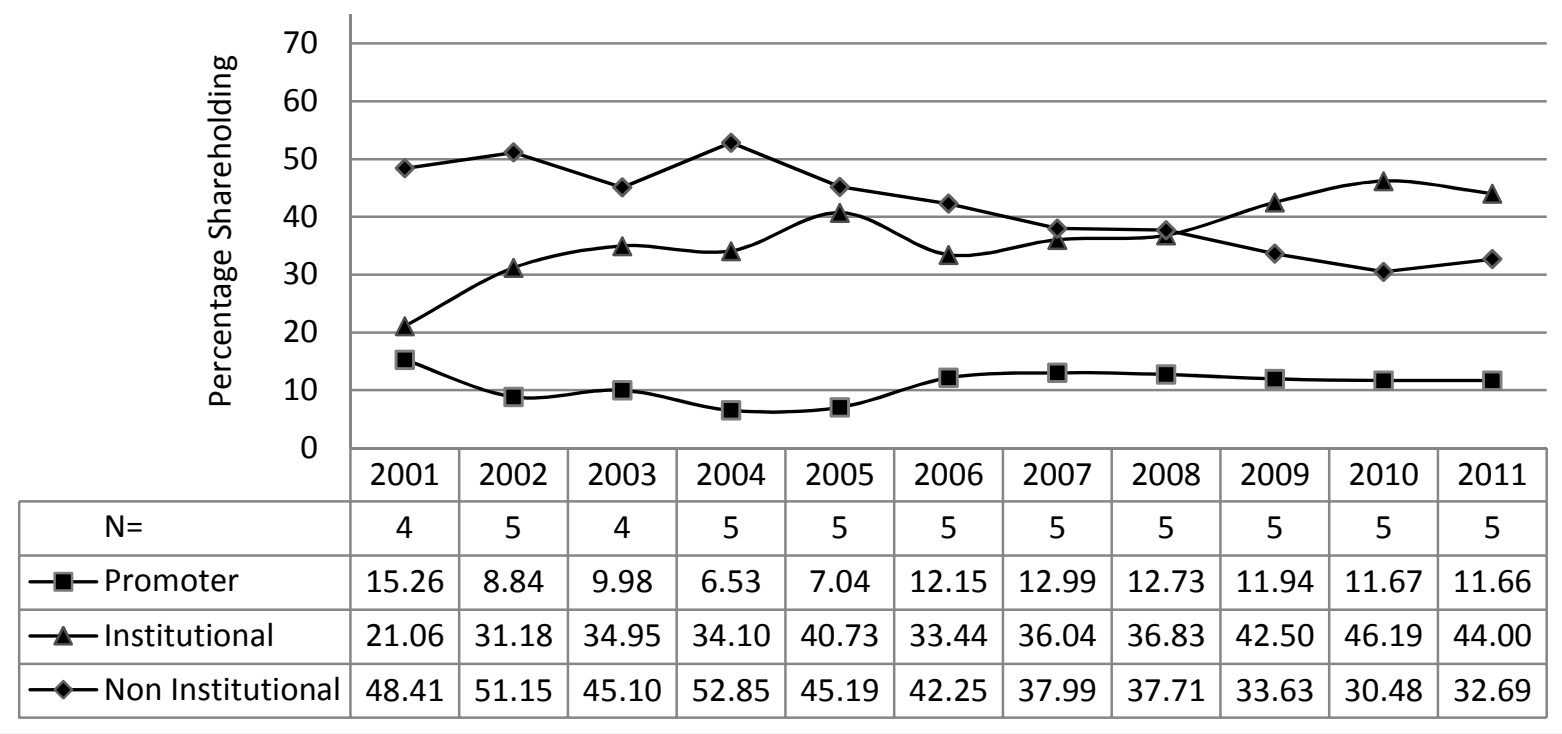

Exhibit BJ-10 JUNIOR NIFTY-Set B-Management Controlled Companies-Median Ownership Trends, 2001-2011

JUNIOR NIFTY-Set B-Management Controlled Companies-Median Ownership Trends, 2001-2011

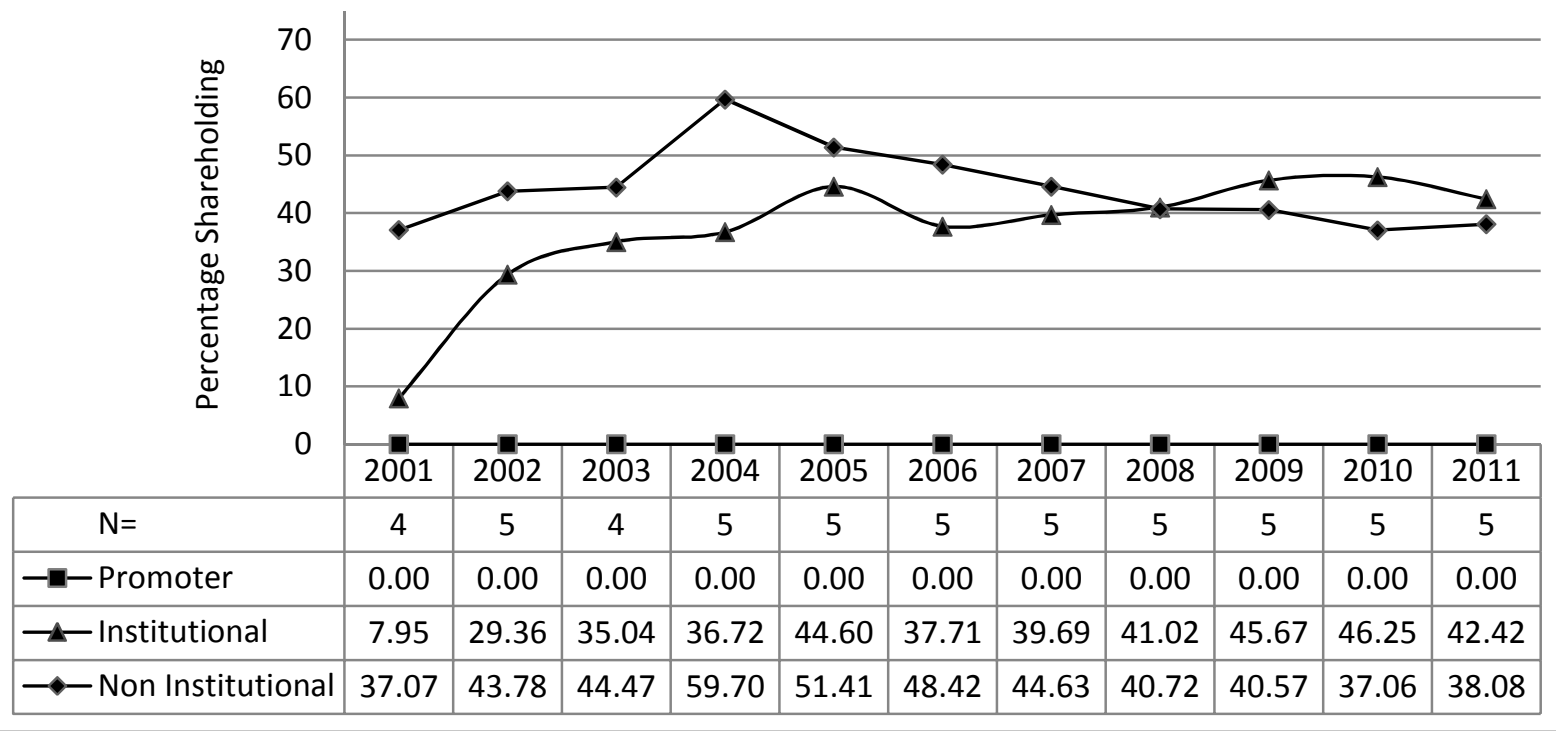

Exhibit BJ-11 JUNIOR NIFTY-Set B-Mean Institutional Ownership Trends, 2001-2011 


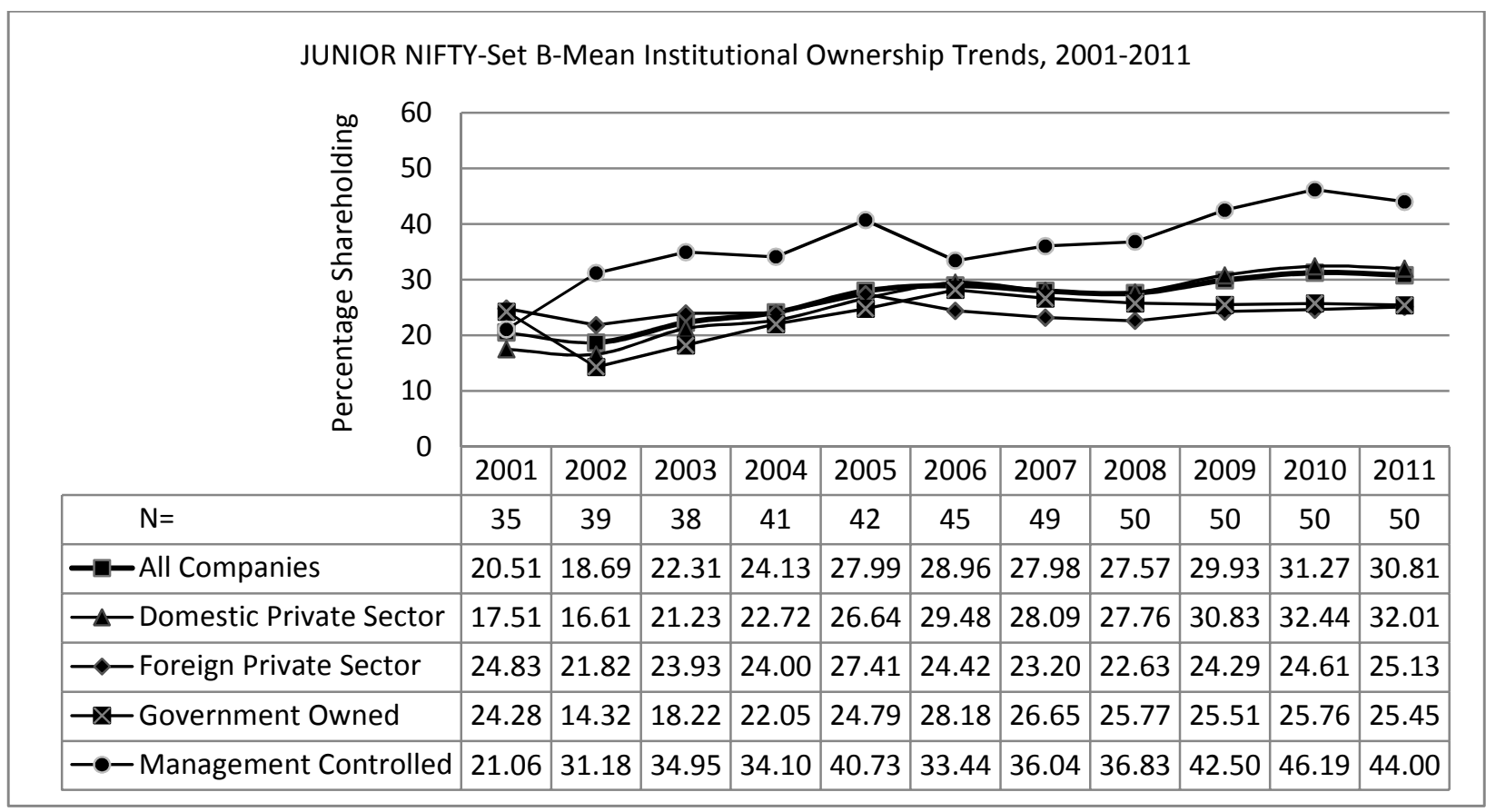

Exhibit BJ-12 JUNIOR NIFTY-Set B-Median Institutional Ownership Trends, 2001-2011

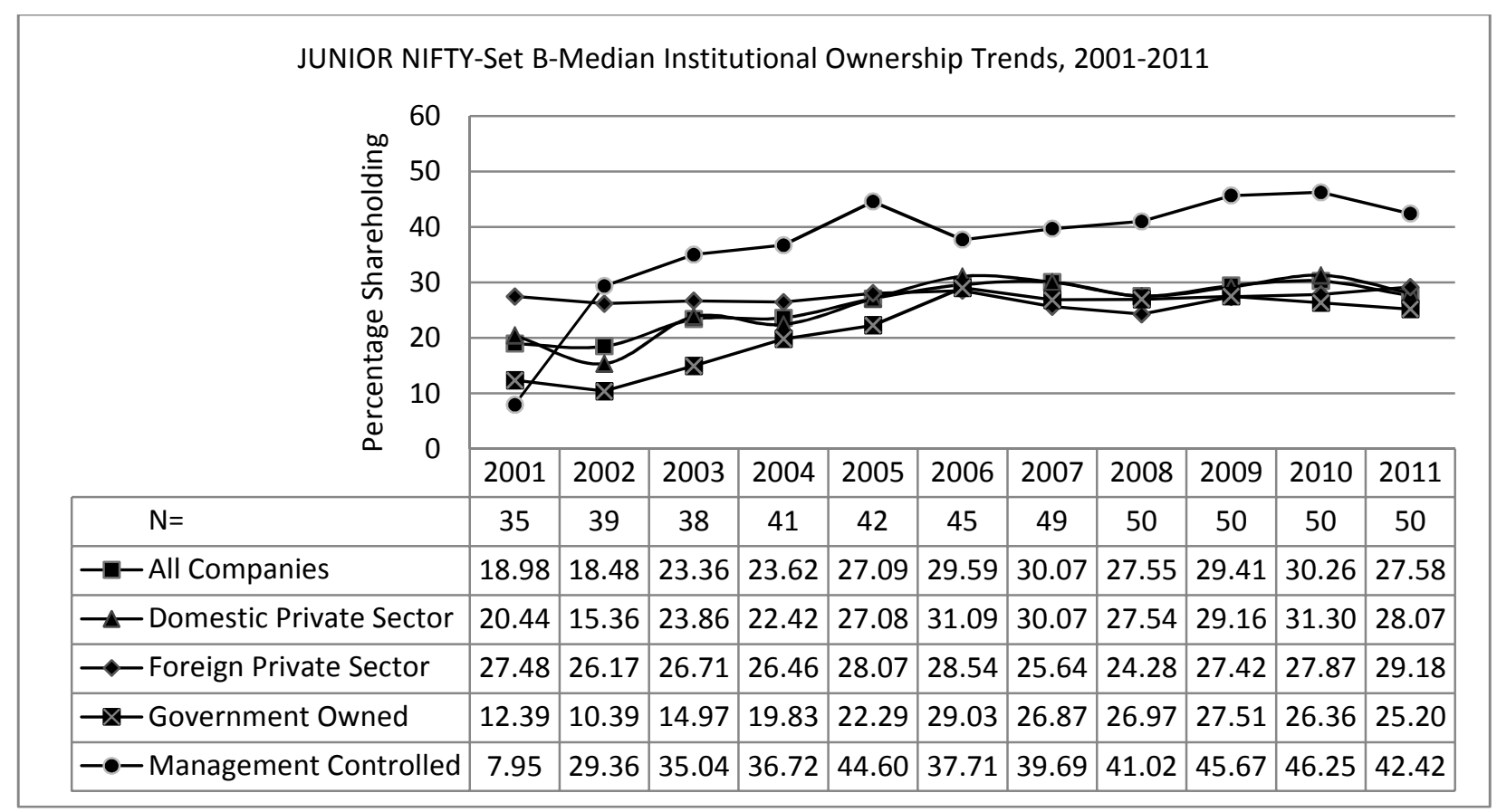


Exhibit BJ-13 JUNIOR NIFTY-Set B-Mean Non Institutional Ownership Trends, 2001-2011

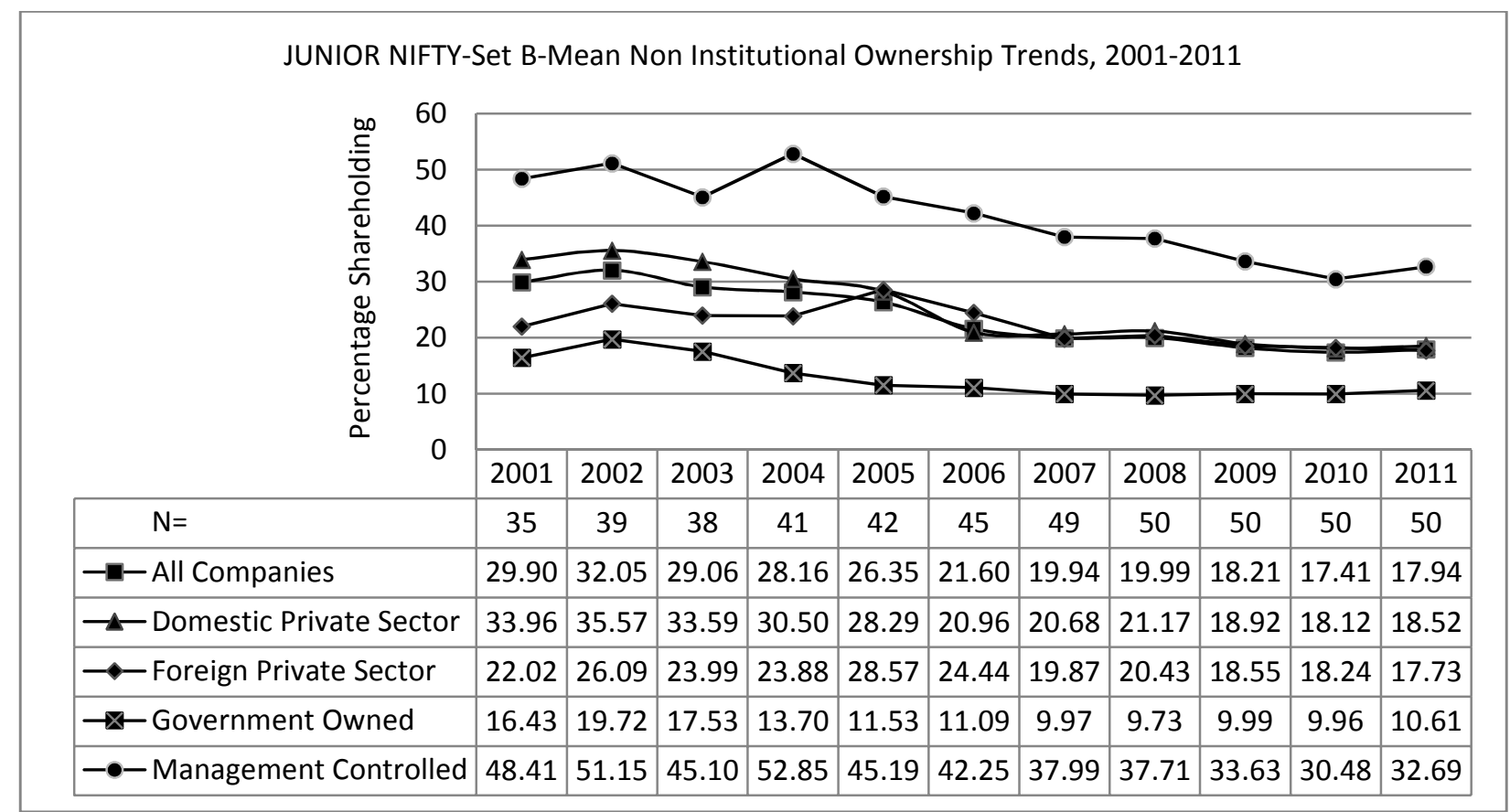

Exhibit BJ-14 JUNIOR NIFTY-Set B-Median Non Institutional Ownership Trends, 2001-2011

JUNIOR NIFTY-Set B-Median Non Institutional Ownership Trends, 2001-2011

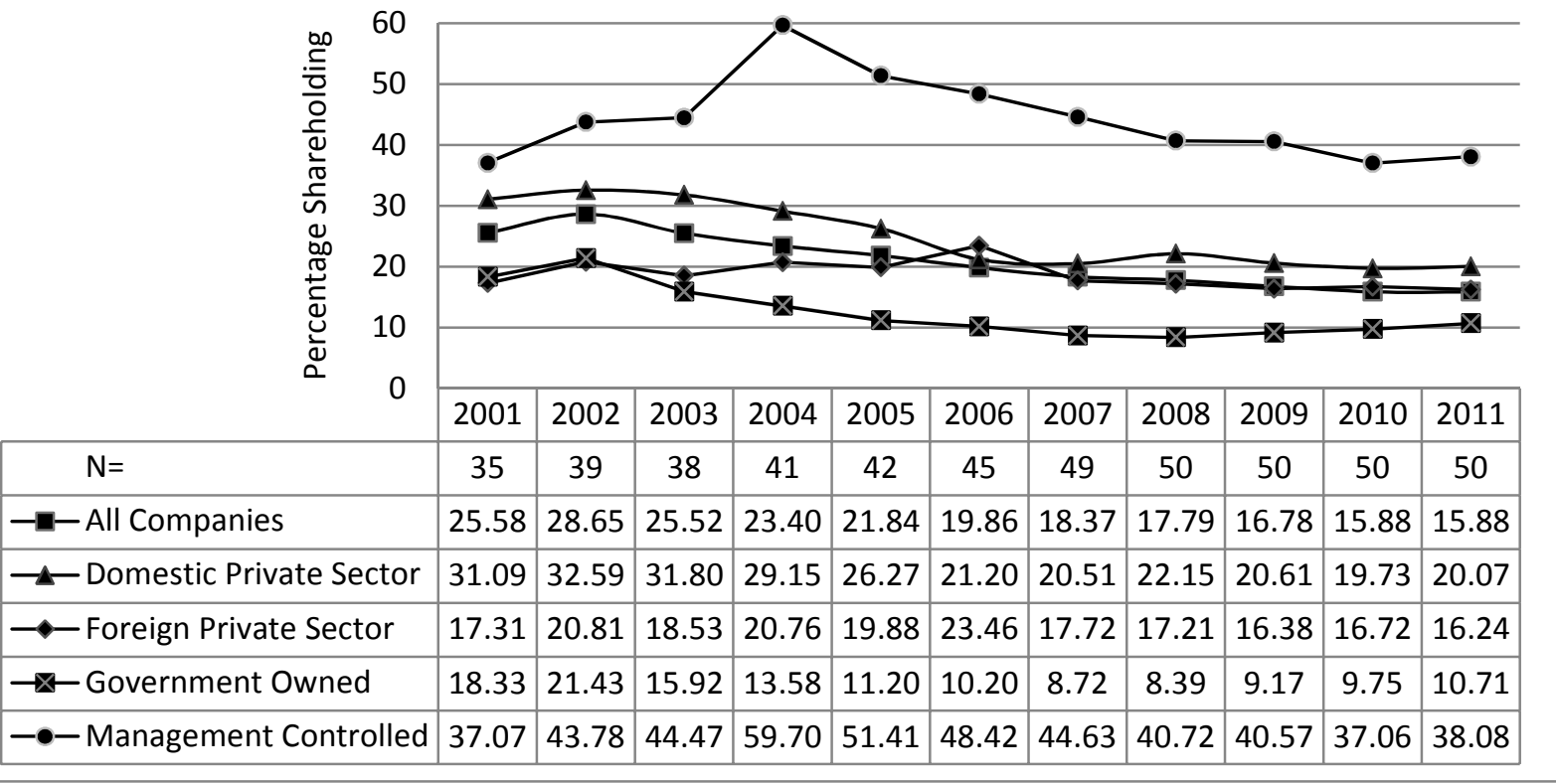


Exhibit BC-1 CNX-100-Set B-Mean Ownership Trends, 2001-2011

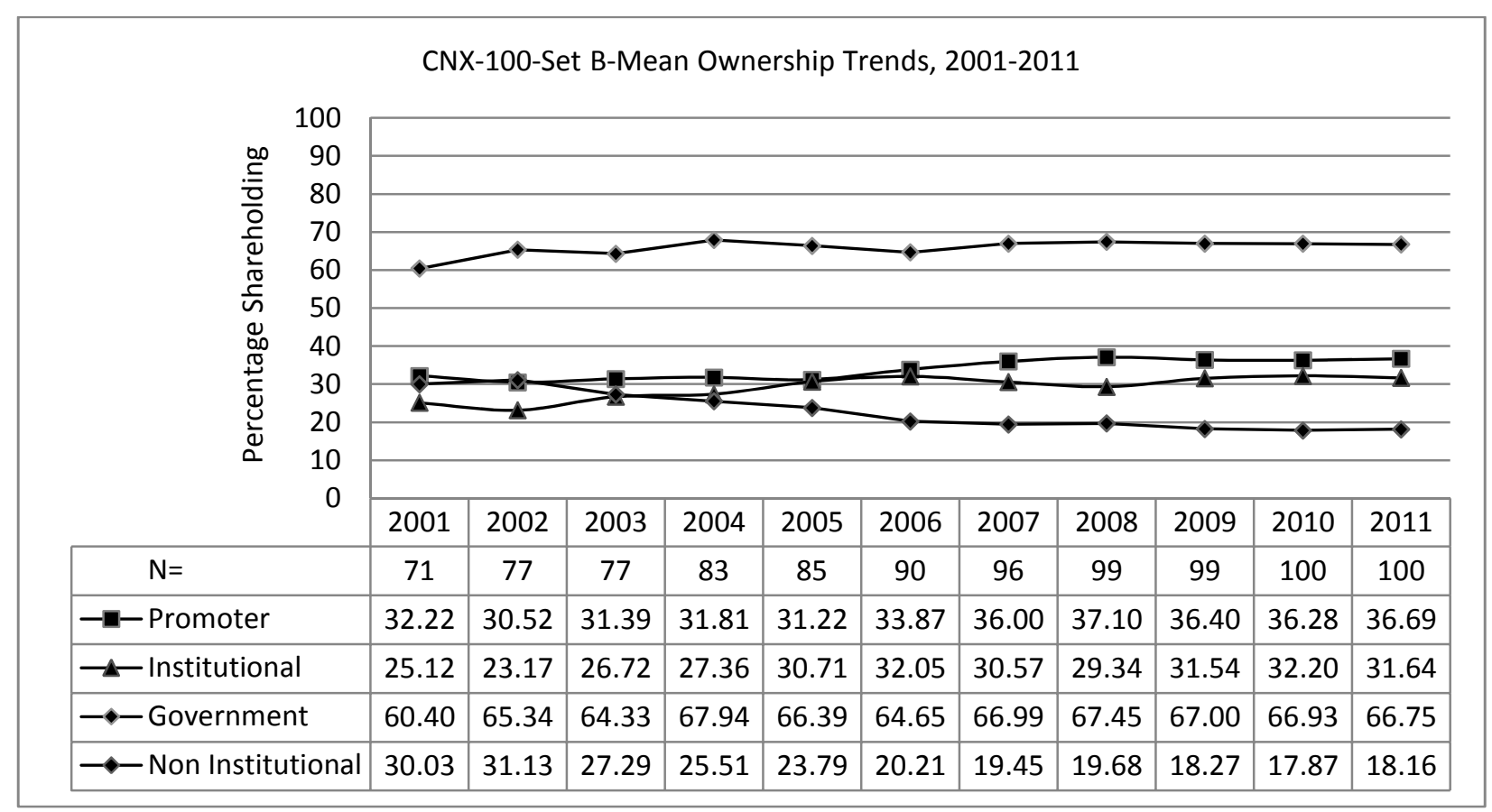

Exhibit BC-2 CNX-100-Set B-Median Ownership Trends, 2001-2011 


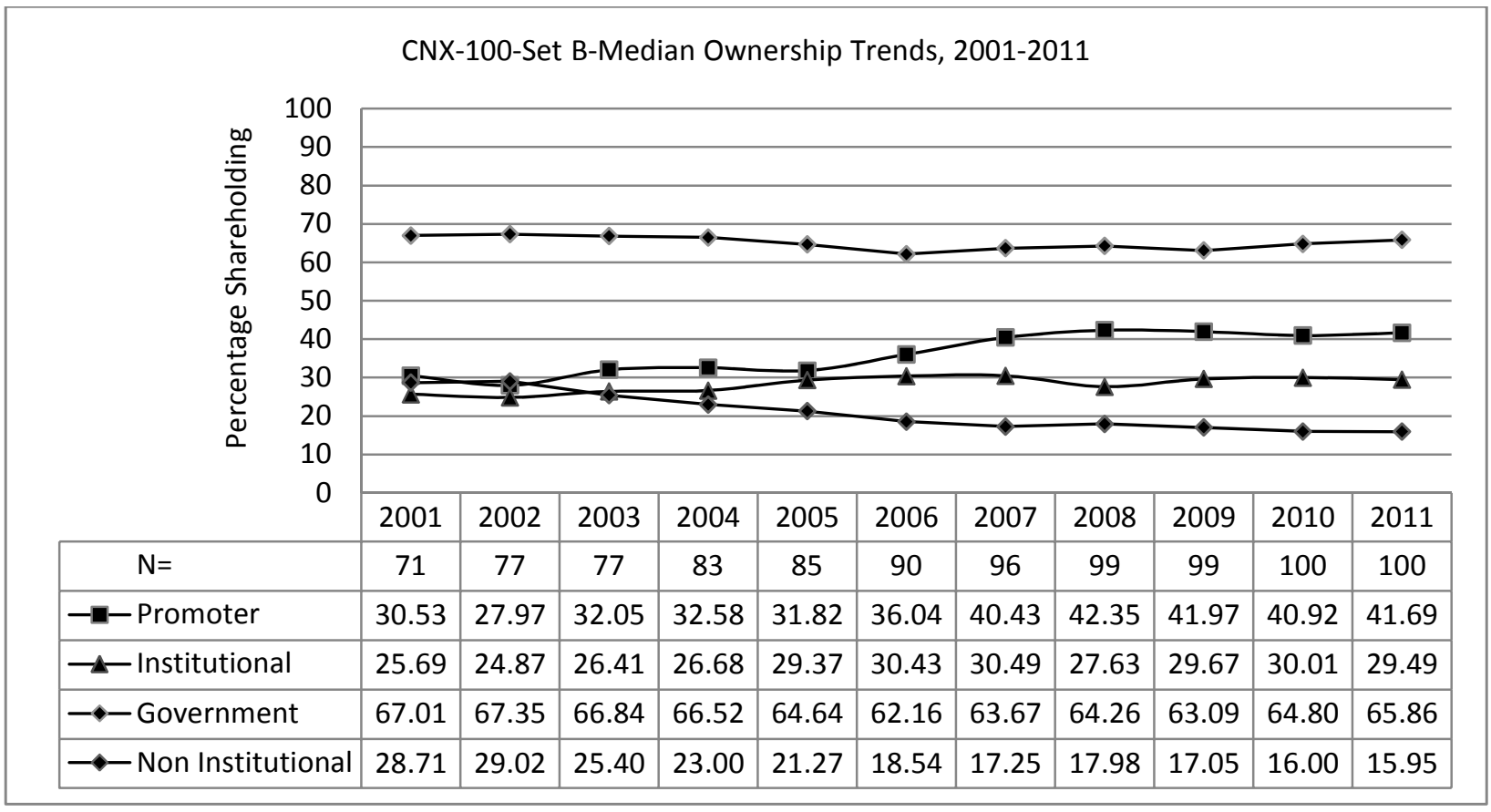

Exhibit BC-3 CNX-100-Set B-Domestic Pvt. Sector Companies-Mean Ownership Trends, 20012011

CNX-100-Set B-Domestic Pvt. Sector Companies-Mean Ownership Trends, 2001-2011

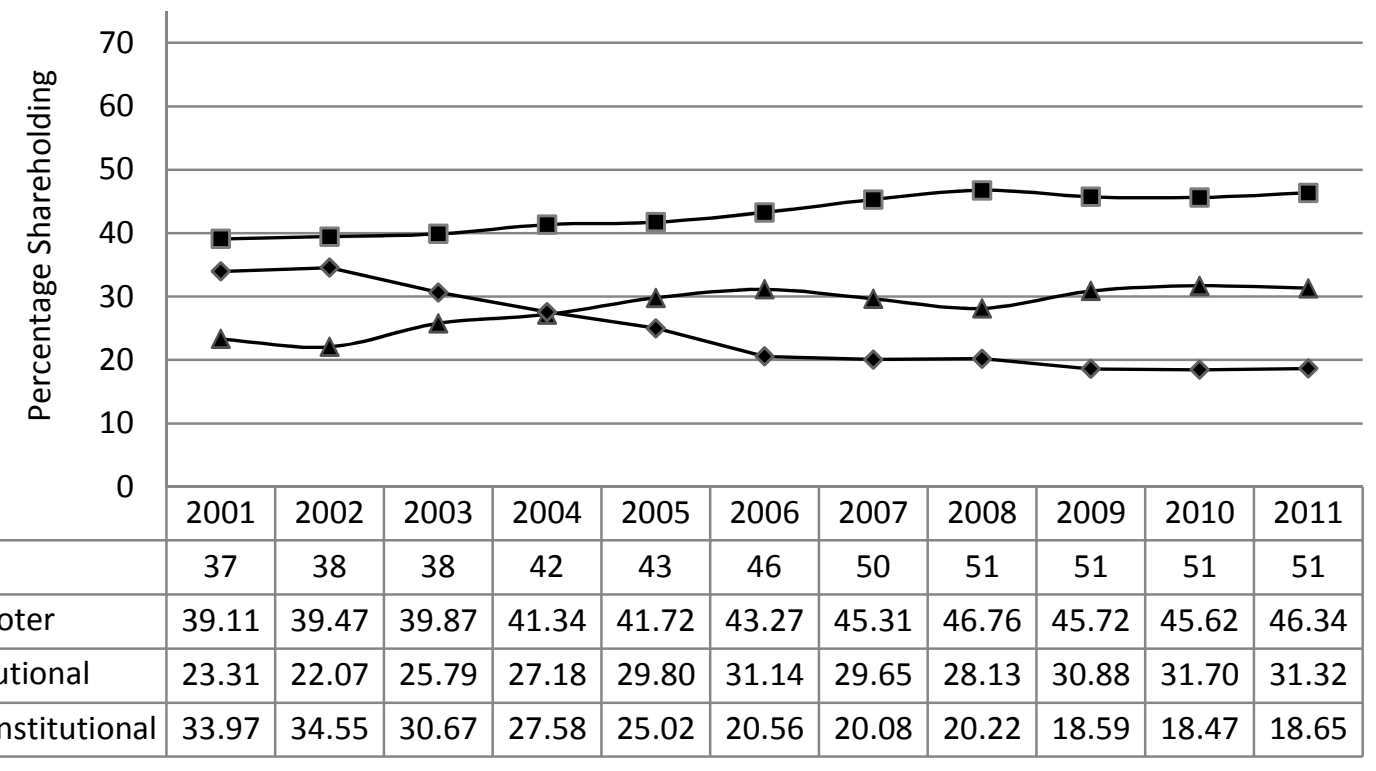


Exhibit BC-4 CNX-100-Set B-Domestic Pvt. Sector Companies-Median Ownership Trends, 2001-2011

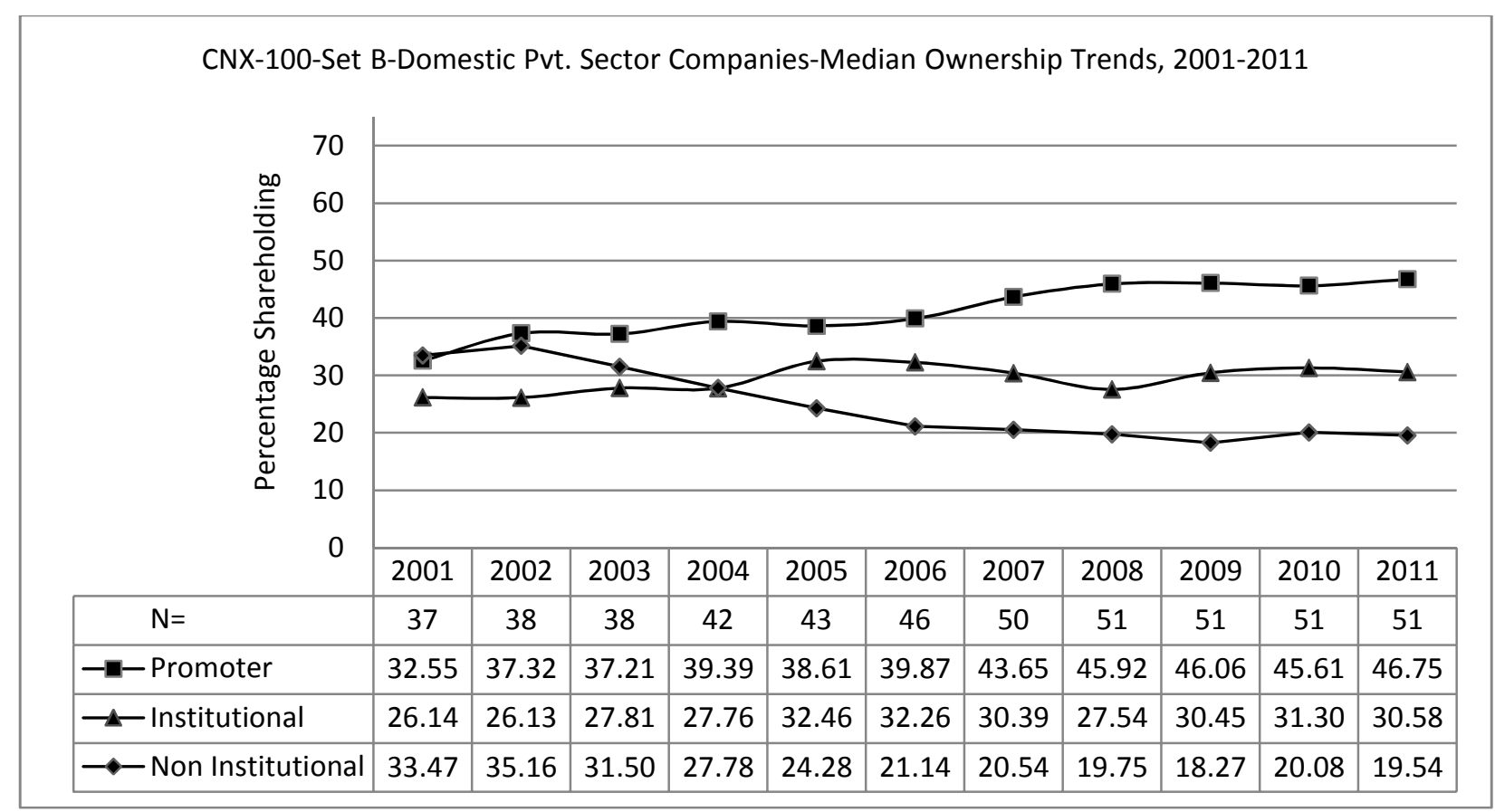

Exhibit BC-5 CNX-100-Set B-Foreign Pvt. Sector Companies-Mean Ownership Trends, 20012011

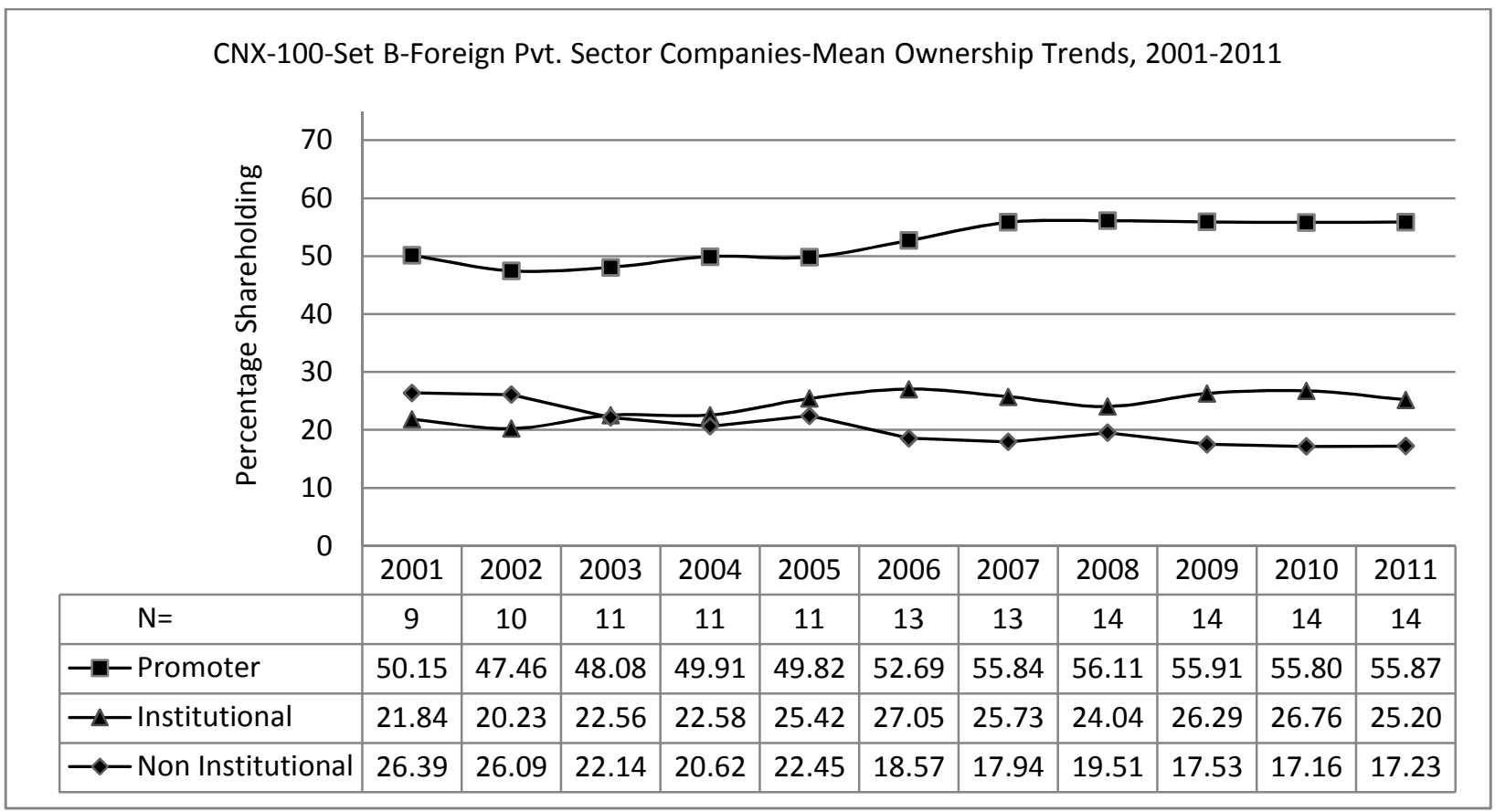


Exhibit BC-6 CNX-100-Set B-Foreign Pvt. Sector Companies-Median Ownership Trends, 20012011

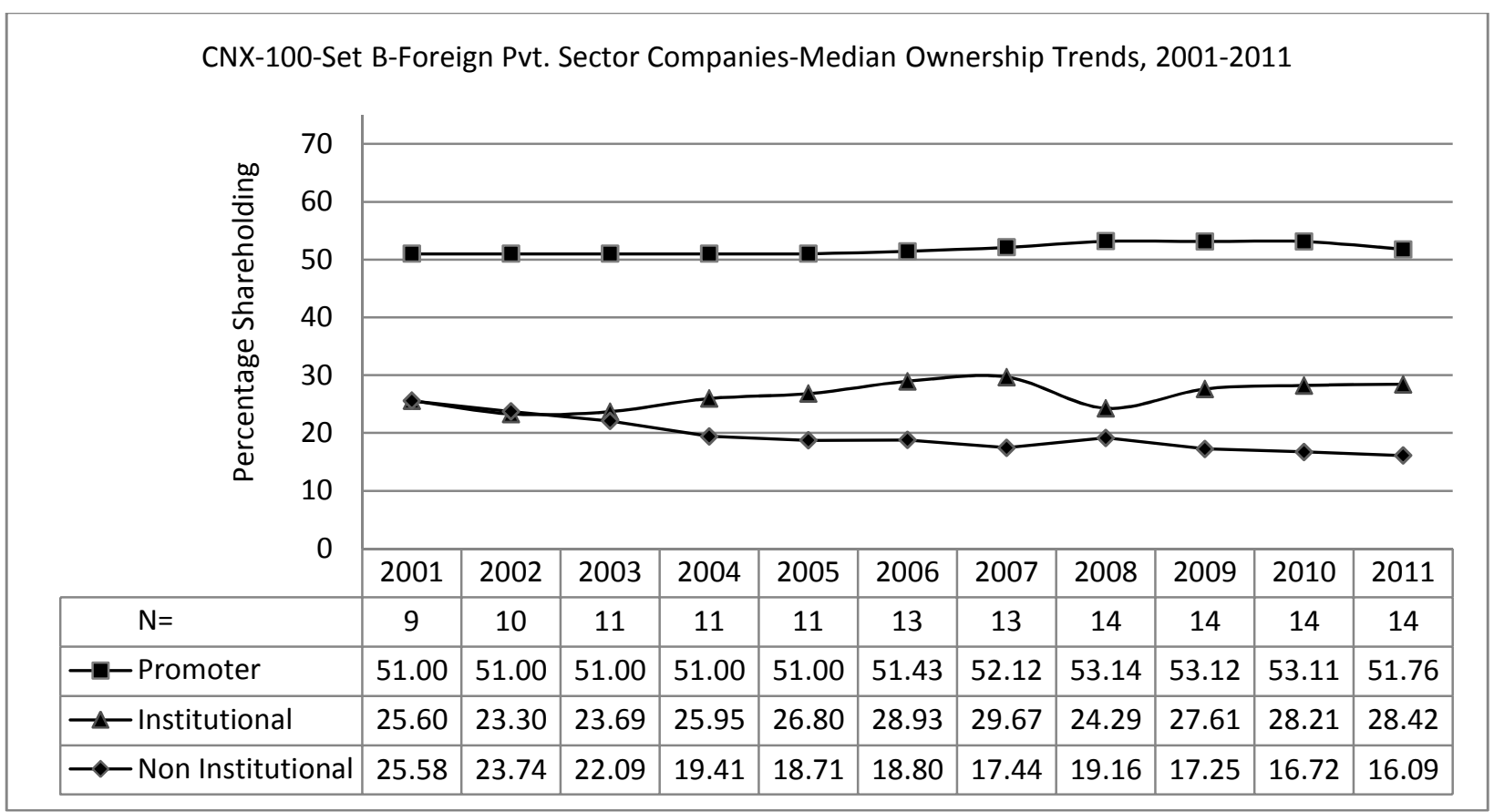

Exhibit BC-7 CNX-100-Set B-Government Owned Companies-Mean Ownership Trends, 20012011 
CNX-100-Set B-Government Owned Companies-Mean Ownership Trends, 2001-2011

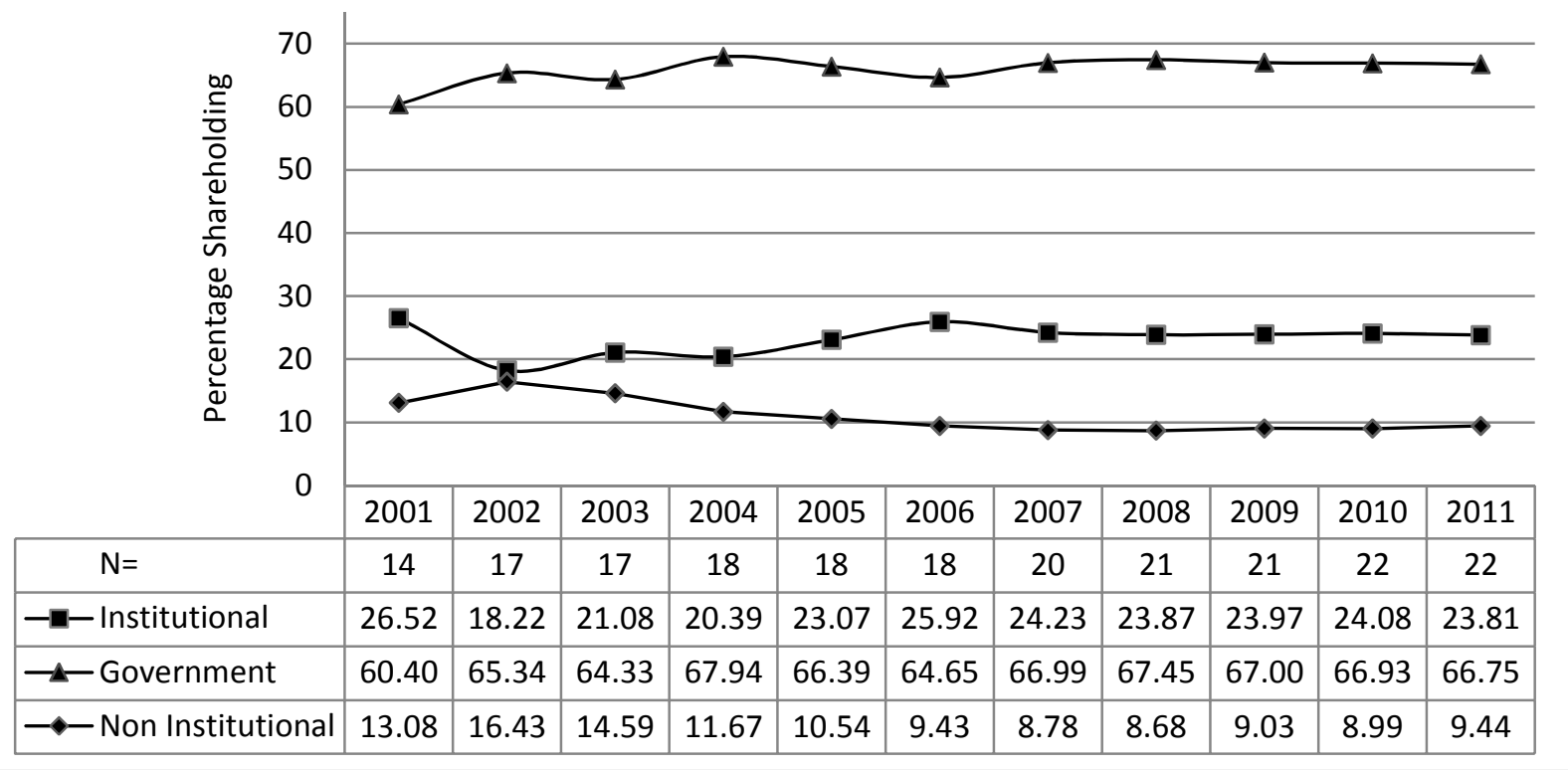

Exhibit BC-8 CNX-100-Set B-Government Owned Companies-Median Ownership Trends, 2001-2011

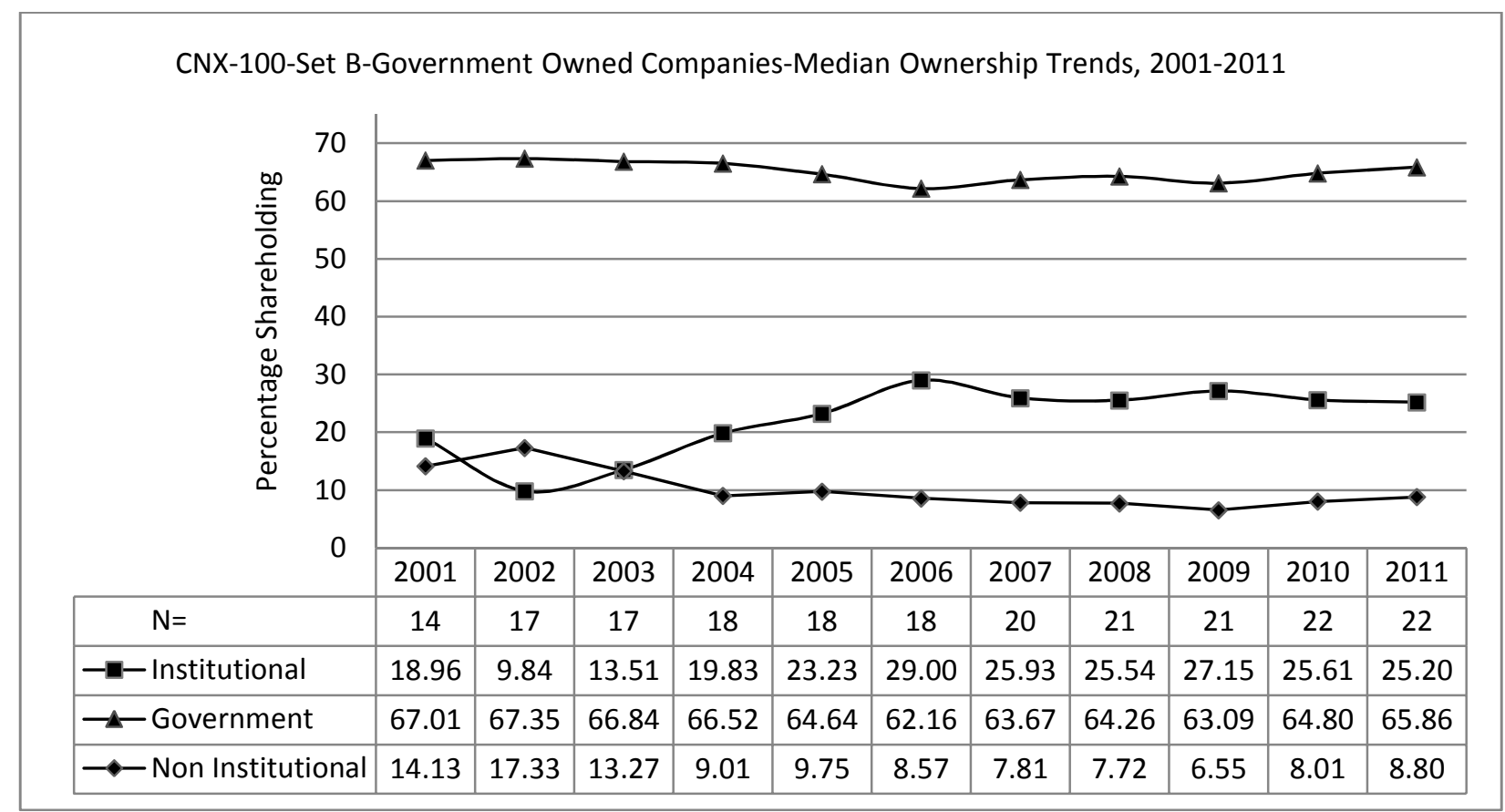

Exhibit BC-9 CNX-100-Set B-Management Controlled Companies-Mean Ownership Trends, 2001-2011 
CNX-100-Set B-Management Controlled Companies-Mean Ownership Trends, 2001-2011

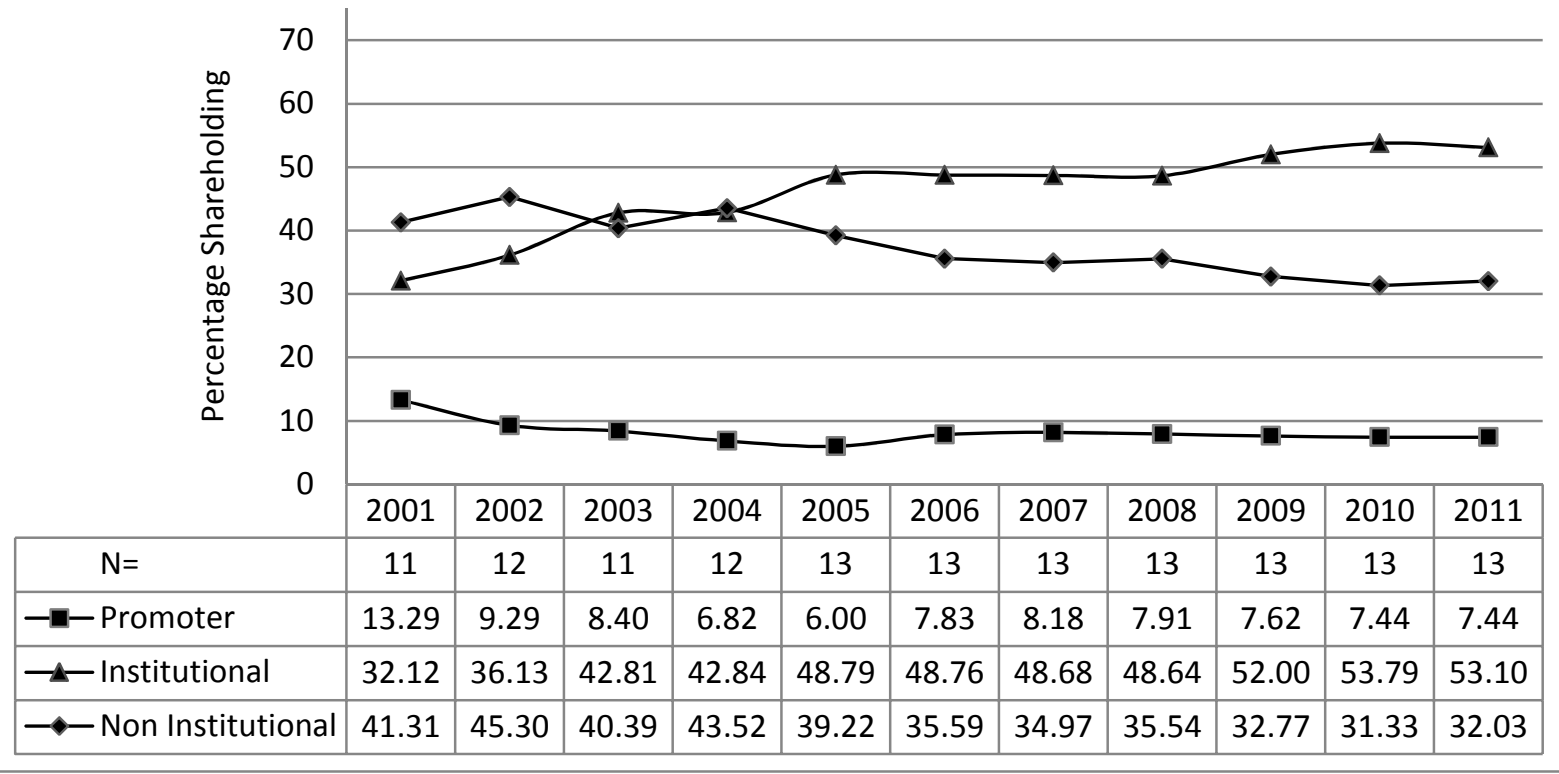

Exhibit BC-10 CNX-100-Set B-Management Controlled Companies-Median Ownership Trends, 2001-2011

CNX-100-Set B-Management Controlled Companies-Median Ownership Trends, 2001-2011

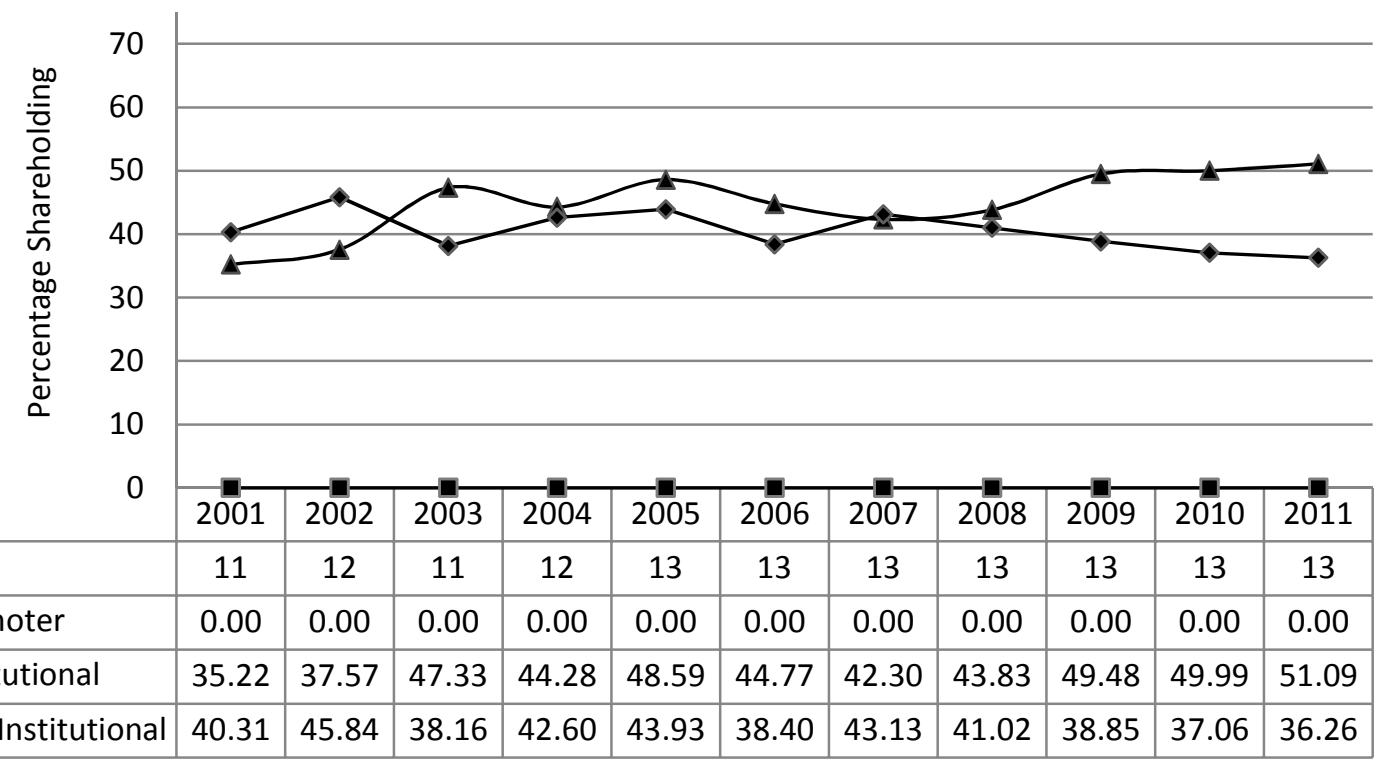


Exhibit BC-11 CNX-100-Set B-Mean Institutional Ownership Trends, 2001-2011

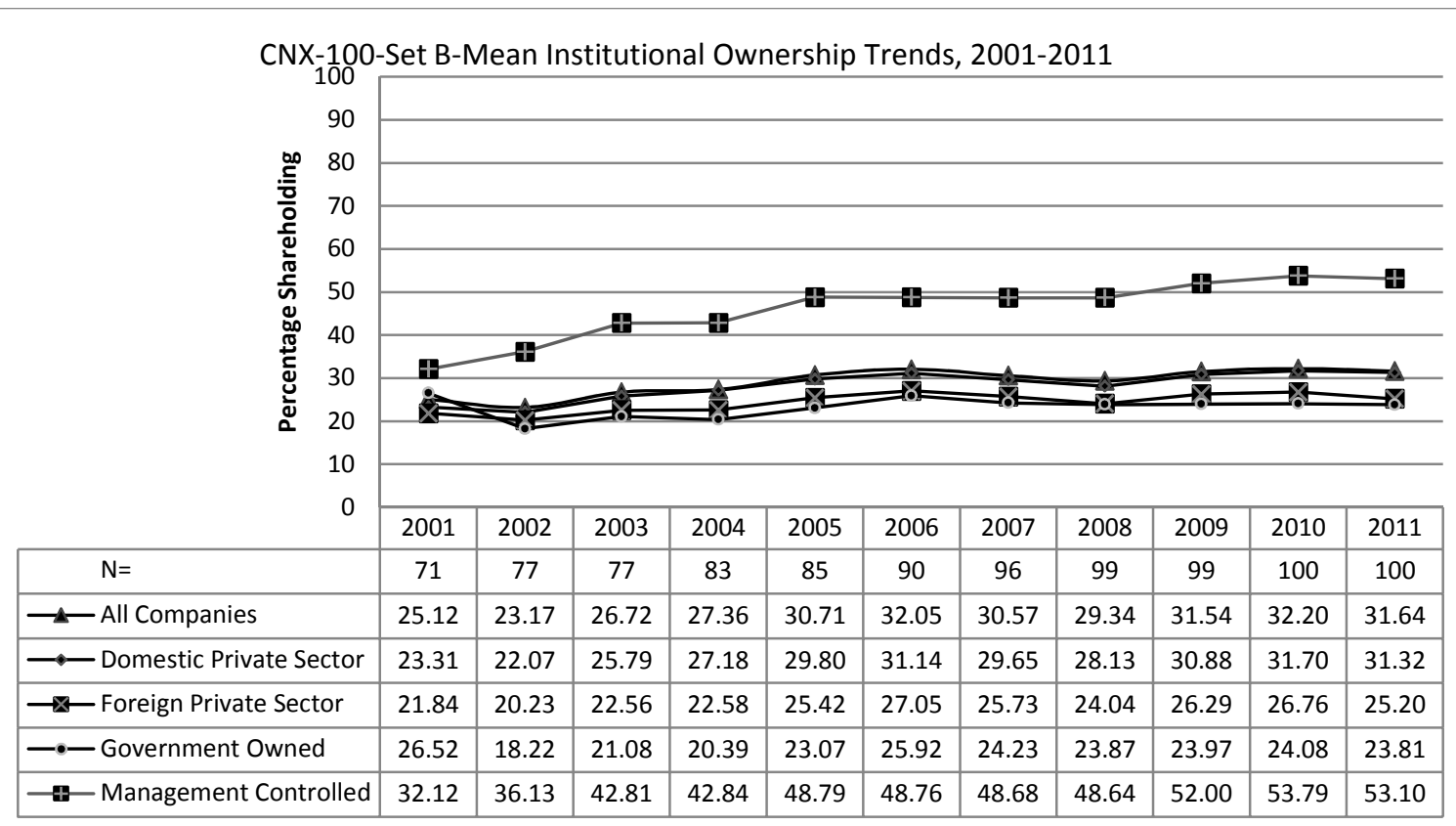

Exhibit BC-12 CNX-100-Set B-Median Institutional Ownership Trends, 2001-2011

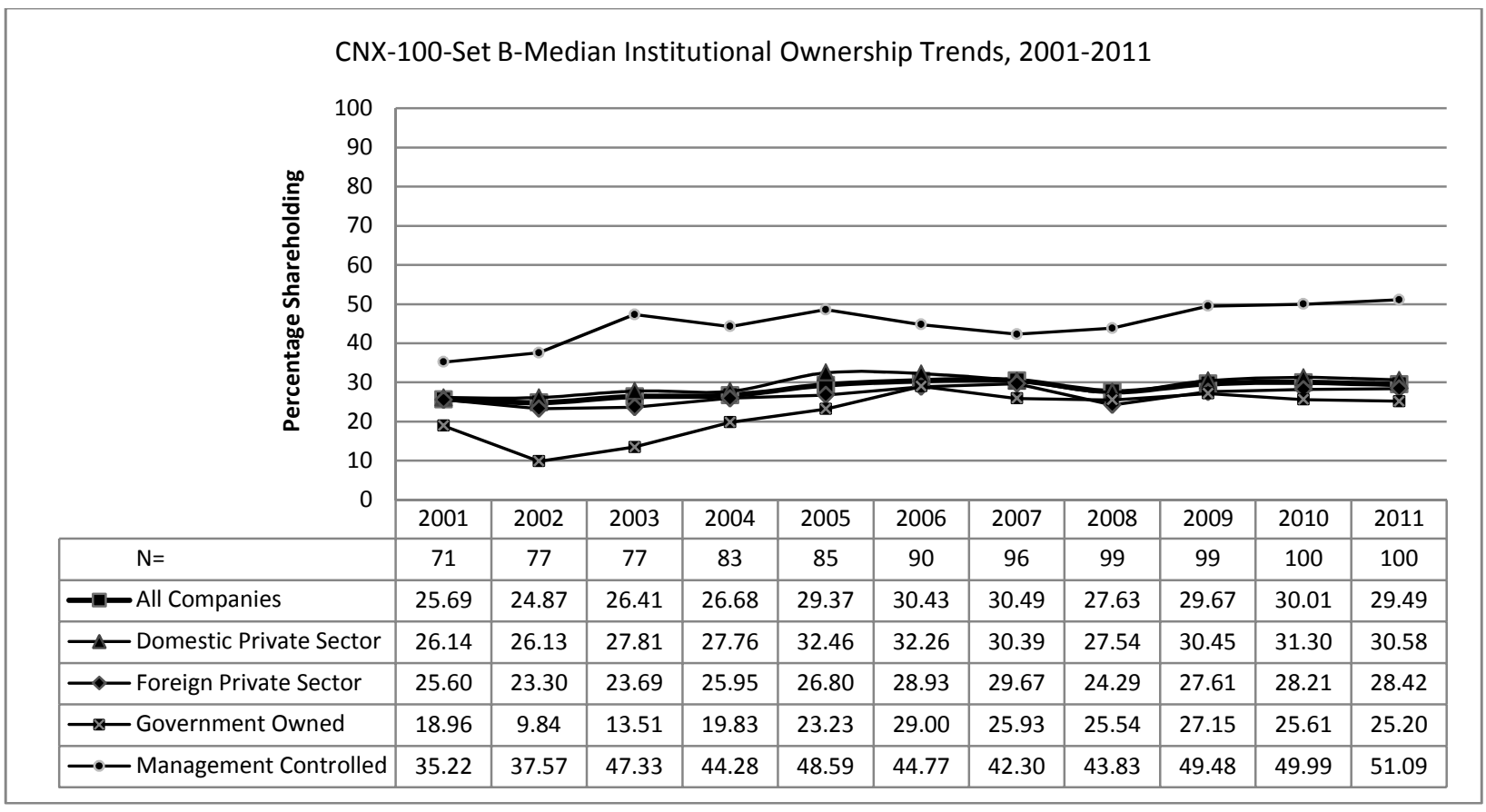


Exhibit BC-13 CNX-100-Set B-Mean Non Institutional Ownership Trends, 2001-2011

\begin{tabular}{|c|c|c|c|c|c|c|c|c|c|c|c|}
\hline \multicolumn{12}{|c|}{ CNX-100-Set B-Mean Non Institutional Ownership Trends, 2001-2011 } \\
\hline \multirow{10}{*}{ 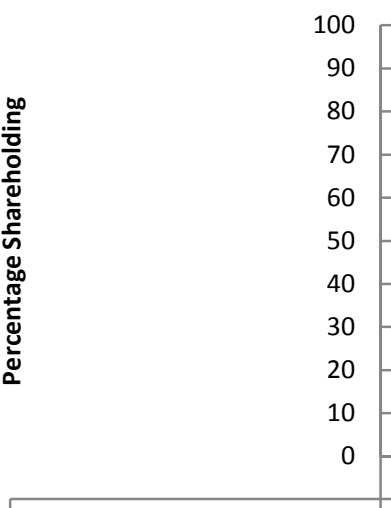 } & & & & & & & & & & & \\
\hline & & & & & & & & & & & \\
\hline & & & & & & & & & & & \\
\hline & & & & & & & & & & & \\
\hline & & & & & & & & & & & \\
\hline & \multicolumn{11}{|c|}{ 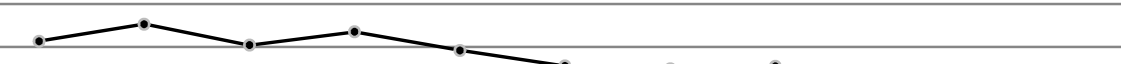 } \\
\hline & \multicolumn{11}{|c|}{$\Rightarrow$} \\
\hline & \multicolumn{11}{|c|}{+2} \\
\hline & \multicolumn{11}{|c|}{$\underset{\longrightarrow}{\Delta-\infty} \longrightarrow$} \\
\hline & 2001 & 2002 & 2003 & 2004 & 2005 & 2006 & 2007 & 2008 & 2009 & 2010 & 2011 \\
\hline $\mathrm{N}=$ & 71 & 77 & 77 & 83 & 85 & 90 & 96 & 99 & 99 & 100 & 100 \\
\hline 一-All Companies & 30.03 & 31.13 & 27.29 & 25.51 & 23.79 & 20.21 & 19.45 & 19.68 & 18.27 & 17.87 & 18.16 \\
\hline$\longrightarrow$ - Domestic Private Sector & 33.97 & 34.55 & 30.67 & 27.58 & 25.02 & 20.56 & 20.08 & 20.22 & 18.59 & 18.47 & 18.65 \\
\hline$\longrightarrow$ Foreign Private Sector & 26.39 & 26.09 & 22.14 & 20.62 & 22.45 & 18.57 & 17.94 & 19.51 & 17.53 & 17.16 & 17.23 \\
\hline$\rightarrow \infty$ Government Owned & 13.08 & 16.43 & 14.59 & 11.67 & 10.54 & 9.43 & 8.78 & 8.68 & 9.03 & 8.99 & 9.44 \\
\hline —-_Management Controlled & 41.31 & 45.30 & 40.39 & 43.52 & 39.22 & 35.59 & 34.97 & 35.54 & 32.77 & 31.33 & 32.03 \\
\hline
\end{tabular}

Exhibit BC-14 CNX-100-Set B-Median Non Institutional Ownership Trends, 2001-2011 
CNX-100-Set B-Median Non Institutional Ownership Trends, 2001-2011

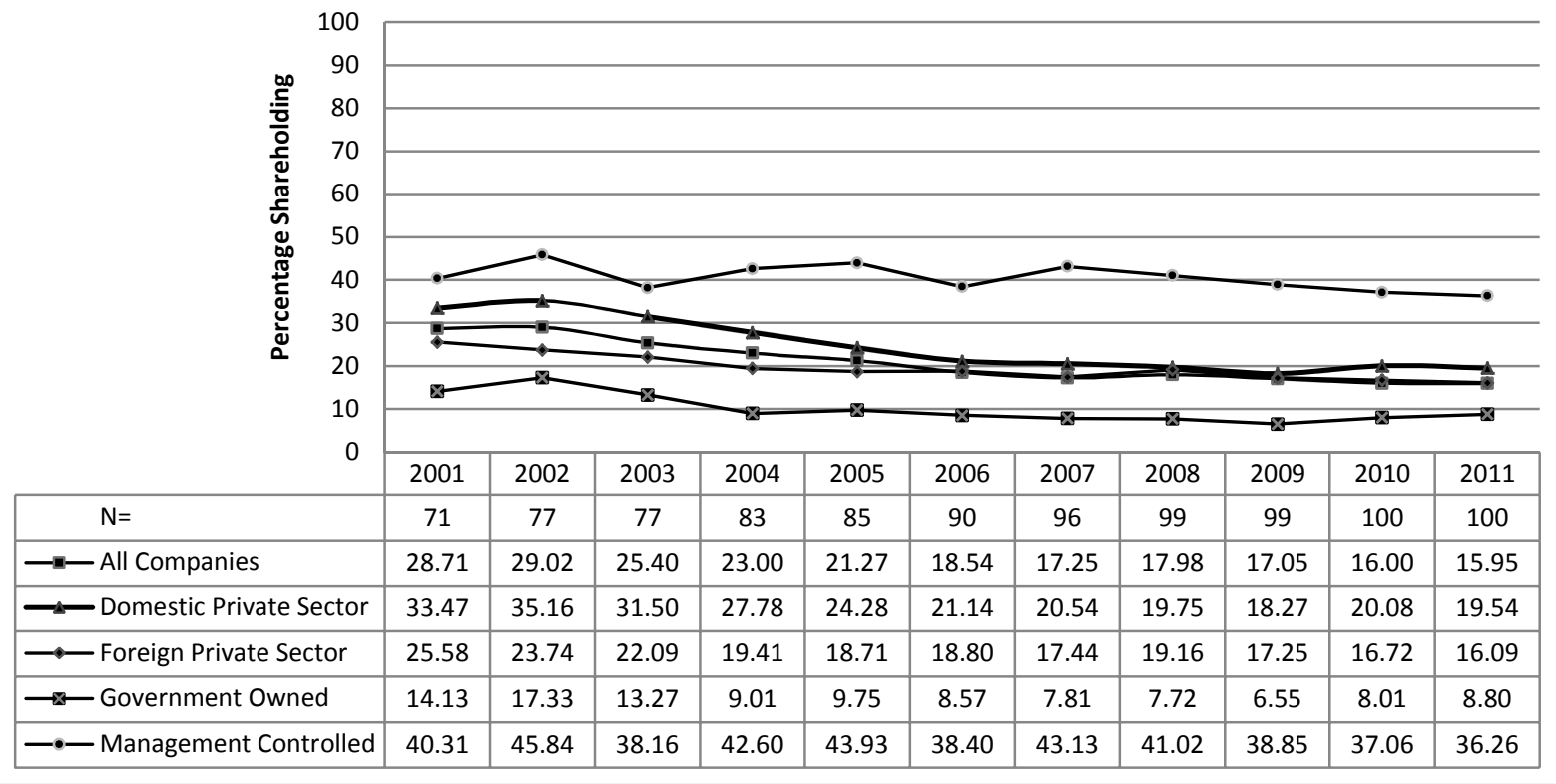

Exhibit-11, List of Companies in Set $A$ as per Index Listing (N=NIFTY and J=JUNIOR NIFTY)

(A blank indicates absence from the Index that year)

\begin{tabular}{|c|c|c|c|c|c|c|c|c|c|c|c|c|}
\hline S.No & Name of Company & 2001 & 2002 & 2003 & 2004 & 2005 & 2006 & 2007 & 2008 & 2009 & 2010 & 2011 \\
\hline 1 & ABB LTD. & $\mathrm{N}$ & $\mathrm{N}$ & $\mathrm{N}$ & $\mathrm{N}$ & $\mathrm{N}$ & $\mathrm{N}$ & $\mathrm{N}$ & $\mathrm{N}$ & $\mathrm{N}$ & & \\
\hline 2 & ACC LTD. & $\mathrm{N}$ & $\mathrm{N}$ & $\mathrm{N}$ & $\mathrm{N}$ & $\mathrm{N}$ & $\mathrm{N}$ & $\mathrm{N}$ & $\mathrm{N}$ & $\mathrm{N}$ & $\mathrm{N}$ & $\mathrm{N}$ \\
\hline 3 & ADANI ENTERPRISES LTD. & & & & & & & & & J & J & J \\
\hline 4 & ADANI PORTS AND SPECIAL ECONOMIC ZONE LTD. & & & & & & & & J & J & J & $J$ \\
\hline 5 & ADITYA BIRLA NUVO LTD. & & & & & & & J & J & $\mathrm{J}$ & J & $J$ \\
\hline 6 & AMBUJA CEMENTS LTD. & $\mathrm{N}$ & $\mathrm{N}$ & $\mathrm{N}$ & $\mathrm{N}$ & $\mathrm{N}$ & $\mathrm{N}$ & $\mathrm{N}$ & $\mathrm{N}$ & $\mathrm{N}$ & $\mathrm{N}$ & $\mathrm{N}$ \\
\hline 7 & ANDHRA BANK & & & J & J & J & J & J & J & J & J & J \\
\hline 8 & APOLLO TYRES LTD. & J & J & J & J & J & J & J & J & & & \\
\hline 9 & APTECH LTD. & J & & & & & & & & & & \\
\hline 10 & ASHOK LEYLAND LTD. & $J$ & J & J & J & J & J & J & J & $J$ & J & J \\
\hline 11 & ASIAN PAINTS INDIA LTD & $\mathrm{N}$ & & & & & & & & & & \\
\hline 12 & ASIAN PAINTS LTD. & & & J & J & J & J & J & J & J & J & J \\
\hline 13 & AUROBINDO PHARMA LTD. & J & J & J & J & J & J & J & & & & \\
\hline 14 & AVENTIS PHARMA LTD. & & J & J & J & J & J & J & J & & & \\
\hline 15 & AXIS BANK LTD. & & & J & J & J & J & J & J & $\mathrm{N}$ & $\mathrm{N}$ & $\mathrm{N}$ \\
\hline 16 & BAJAJ AUTO LTD. & $\mathrm{N}$ & $\mathrm{N}$ & $\mathrm{N}$ & $\mathrm{N}$ & $\mathrm{N}$ & $\mathrm{N}$ & $\mathrm{N}$ & & J & $\mathrm{N}$ & $\mathrm{N}$ \\
\hline 17 & BANK OF BARODA & J & J & J & J & J & J & J & J & J & $J$ & J \\
\hline 18 & BANK OF INDIA & & J & $J$ & J & J & $\mathrm{J}$ & J & $\mathrm{J}$ & J & $\mathrm{J}$ & J \\
\hline
\end{tabular}




\begin{tabular}{|c|c|c|c|c|c|c|c|c|c|c|c|c|}
\hline S.No & Name of Company & 2001 & 2002 & 2003 & 2004 & 2005 & 2006 & 2007 & 2008 & 2009 & 2010 & 2011 \\
\hline 19 & BATA INDIA LTD & J & & & & & & & & & & \\
\hline 20 & BHARAT ELECTRONICS LTD. & & J & J & $\mathrm{J}$ & J & J & J & $\mathrm{J}$ & J & J & J \\
\hline 21 & BHARAT FORGE LTD. & & & & J & J & J & J & $\mathrm{J}$ & $\mathrm{J}$ & J & J \\
\hline 22 & BHARAT HEAVY ELECTRICALS LTD. & $\mathrm{N}$ & $\mathrm{N}$ & $\mathrm{N}$ & $\mathrm{N}$ & $\mathrm{N}$ & $\mathrm{N}$ & $\mathrm{N}$ & $\mathrm{N}$ & $\mathrm{N}$ & $\mathrm{N}$ & $\mathrm{N}$ \\
\hline 23 & BHARAT PETROLEUM CORPORATION LTD. & & $\mathrm{N}$ & N & $\mathrm{N}$ & $\mathrm{N}$ & $\mathrm{N}$ & N & N & $\mathrm{N}$ & $\mathrm{N}$ & $\mathrm{N}$ \\
\hline 24 & BHARTI AIRTEL LTD. & & & $\mathrm{J}$ & N & $\mathrm{N}$ & N & N & N & N & N & $\mathrm{N}$ \\
\hline 25 & BIOCON LTD. & & & & J & J & J & $\mathrm{J}$ & J & J & J & J \\
\hline 26 & BOMBAY DYEING \& MFG. CO L & J & & & & & & & & & & \\
\hline 27 & BONGAIGAON REFINERY \& PETROCHEMICALS LTD. & & & & J & $\mathrm{J}$ & J & & & & & \\
\hline 28 & BOSCH LTD. & & & & & & & & & & & J \\
\hline 29 & BRITANNIA INDUSTRIES LTD & $\mathrm{N}$ & N & N & & & & & & & & \\
\hline 30 & BURROUGHS WELLCOME & J & & & & & & & & & & \\
\hline 31 & CADBURY INDIA LTD & J & & & & & & & & & & \\
\hline 32 & CADILA HEALTHCARE LTD. & & & & $\mathrm{J}$ & J & J & J & & & & \\
\hline 33 & CAIRN INDIA LTD. & & & & & & & N & N & $\mathrm{N}$ & $\mathrm{N}$ & $\mathrm{N}$ \\
\hline 34 & CANARA BANK & & & & J & J & J & J & J & $\mathrm{J}$ & J & J \\
\hline 35 & CARRIER AIRCON LTD & J & J & & & & & & & & & \\
\hline 36 & CASTROL INDIA LTD & $\mathrm{N}$ & N & & & & & & & & & \\
\hline 37 & CHENNAI PETROLEUM CORPORATION LTD. & J & J & J & J & J & J & J & J & & & \\
\hline 38 & CIPLA LTD. & $\mathrm{N}$ & $\mathrm{N}$ & N & N & $\mathrm{N}$ & N & N & N & N & N & $\mathrm{N}$ \\
\hline 39 & CMC LTD & & J & J & J & J & & & & & & \\
\hline 40 & COAL INDIA LTD. & & & & & & & & & & & $\mathrm{N}$ \\
\hline 41 & COLGATE PALMOLIVE (INDIA) LTD. & $\mathrm{N}$ & $\mathrm{N}$ & N & N & & & & & J & J & J \\
\hline 42 & CONTAINER CORPORATION OF INDIA LTD. & & J & J & & & J & J & J & J & J & J \\
\hline 43 & CORPORATION BANK & J & J & J & J & J & J & J & J & J & J & \\
\hline 44 & CROMPTON GREAVES LTD. & & & & & & & & & J & J & J \\
\hline 45 & CUMMINS INDIA LTD. & & J & J & $\mathrm{J}$ & J & J & $\mathrm{J}$ & J & $\mathrm{J}$ & J & J \\
\hline 46 & DABUR INDIA LTD. & $\mathrm{N}$ & $\mathrm{N}$ & N & N & $\mathrm{N}$ & $\mathrm{N}$ & & & & & J \\
\hline 47 & DIGITAL GLOBALSOFT LTD. & $\mathrm{N}$ & $\mathrm{N}$ & $\mathrm{N}$ & & & & & & & & \\
\hline 48 & DLF LTD. & & & & & & & & N & N & $\mathrm{N}$ & N \\
\hline 49 & DR. REDDY'S LABORATORIES LTD. & $\mathrm{N}$ & N & $\mathrm{N}$ & $\mathrm{N}$ & $\mathrm{N}$ & $\mathrm{N}$ & $\mathrm{N}$ & $\mathrm{J}$ & $\mathrm{J}$ & $\mathrm{N}$ & $\mathrm{N}$ \\
\hline 50 & E MERCK (INDIA) LTD & J & J & J & & & & & & & & \\
\hline 51 & ESCORTS INDIA LTD & J & J & J & & & & & & & & \\
\hline 52 & EXIDE INDUSTRIES LTD. & & & & & & & & & & J & J \\
\hline 53 & FEDERAL BANK LTD. & & & & & & & & & J & J & J \\
\hline 54 & FINOLEX CABLES LTD & J & $\mathrm{J}$ & J & & & & & & & & \\
\hline 55 & GAIL (INDIA) LTD. & & & N & N & $\mathrm{N}$ & N & N & N & N & N & $\mathrm{N}$ \\
\hline 56 & GERMAN REMEDIES LTD & J & $\mathrm{J}$ & & & & & & & & & \\
\hline
\end{tabular}




\begin{tabular}{|c|c|c|c|c|c|c|c|c|c|c|c|c|}
\hline S.No & Name of Company & 2001 & 2002 & 2003 & 2004 & 2005 & 2006 & 2007 & 2008 & 2009 & 2010 & 2011 \\
\hline 57 & GILLETTE INDIA LTD & J & $\mathrm{J}$ & & & & & & & & & \\
\hline 58 & GLAXOSMITHKLINE CONSUMER & $\mathrm{N}$ & $\mathrm{N}$ & $\mathrm{N}$ & & & & & & & & \\
\hline 59 & GLAXOSMITHKLINE PHARMACEUTICALS LTD. & $\mathrm{N}$ & $\mathrm{N}$ & $\mathrm{N}$ & $\mathrm{N}$ & $\mathrm{N}$ & $\mathrm{N}$ & $\mathrm{N}$ & & J & J & J \\
\hline 60 & GLENMARK PHARMACEUTICALS LTD. & & & & & & & & & J & J & J \\
\hline 61 & GLOBAL TRUST BANK LTD & J & J & & & & & & & & & \\
\hline 62 & GMR INFRASTRUCTURE LTD. & & & & & & & J & J & J & J & J \\
\hline 63 & GRASIM INDUSTRIES LTD. & $\mathrm{N}$ & $\mathrm{N}$ & $\mathrm{N}$ & $\mathrm{N}$ & N & $\mathrm{N}$ & $\mathrm{N}$ & $\mathrm{N}$ & $\mathrm{N}$ & J & $\mathrm{N}$ \\
\hline 64 & GREAT EASTERN SHIPPING CO & J & $\mathrm{J}$ & J & $\mathrm{J}$ & $\mathrm{J}$ & & & & & & \\
\hline 65 & GTL LTD & & J & J & & & & & & & & \\
\hline 66 & HCL INFOSYSTEMS LTD & $\mathrm{N}$ & & & & & & & & & & \\
\hline 67 & HCL TECHNOLOGIES LTD. & & $\mathrm{N}$ & $\mathrm{N}$ & $\mathrm{N}$ & $\mathrm{N}$ & $\mathrm{N}$ & $\mathrm{N}$ & $\mathrm{N}$ & $\mathrm{N}$ & $\mathrm{N}$ & N \\
\hline 68 & HDFC BANK LTD. & $\mathrm{N}$ & $\mathrm{N}$ & $\mathrm{N}$ & $\mathrm{N}$ & N & $\mathrm{N}$ & $\mathrm{N}$ & $\mathrm{N}$ & $\mathrm{N}$ & $\mathrm{N}$ & N \\
\hline 69 & HERO MOTOCORP LTD. & $\mathrm{N}$ & $\mathrm{N}$ & $\mathrm{N}$ & $\mathrm{N}$ & N & N & $\mathrm{N}$ & $\mathrm{N}$ & $\mathrm{N}$ & $\mathrm{N}$ & $\mathrm{N}$ \\
\hline 70 & HIMACHAL FUTURISTICS COMM & J & J & J & & & & & & & & \\
\hline 71 & HINDALCO INDUSTRIES LTD. & $\mathrm{N}$ & $\mathrm{N}$ & $\mathrm{N}$ & $\mathrm{N}$ & $\mathrm{N}$ & $\mathrm{N}$ & $\mathrm{N}$ & $\mathrm{N}$ & $\mathrm{N}$ & N & $\mathrm{N}$ \\
\hline 72 & HINDUSTAN PETROLEUM CORPORATION LTD. & $\mathrm{N}$ & $\mathrm{N}$ & $\mathrm{N}$ & $\mathrm{N}$ & $\mathrm{N}$ & $\mathrm{N}$ & & & J & J & J \\
\hline 73 & HINDUSTAN UNILEVER LTD. & $\mathrm{N}$ & $\mathrm{N}$ & $\mathrm{N}$ & $\mathrm{N}$ & $\mathrm{N}$ & $\mathrm{N}$ & $\mathrm{N}$ & $\mathrm{N}$ & $\mathrm{N}$ & N & $\mathrm{N}$ \\
\hline 74 & HINDUSTAN ZINC LTD & & J & & & & & & & & & \\
\hline 75 & HOUSING DEVELOPMENT AND INFRASTRUCTURE LTD. & & & & & & & & J & J & J & J \\
\hline 76 & HOUSING DEVELOPMENT FINANCE CORPORATION LTD. & $\mathrm{N}$ & $\mathrm{N}$ & $\mathrm{N}$ & $\mathrm{N}$ & $\mathrm{N}$ & $\mathrm{N}$ & $\mathrm{N}$ & $\mathrm{N}$ & N & N & $\mathrm{N}$ \\
\hline 77 & HUGHES SOFTWARE SYSTEMS & J & J & J & J & J & & & & & & \\
\hline 78 & I T C LTD. & $\mathrm{N}$ & $\mathrm{N}$ & $\mathrm{N}$ & $\mathrm{N}$ & $\mathrm{N}$ & $\mathrm{N}$ & $\mathrm{N}$ & $\mathrm{N}$ & $\mathrm{N}$ & N & $\mathrm{N}$ \\
\hline 79 & IBP CO. LTD. & & & & J & J & J & & & & & \\
\hline 80 & ICI INDIA LTD & J & J & J & & & & & & & & \\
\hline 81 & ICICI BANK LTD. & $\mathrm{J}$ & $\mathrm{N}$ & $\mathrm{N}$ & $\mathrm{N}$ & N & $\mathrm{N}$ & $\mathrm{N}$ & $\mathrm{N}$ & N & N & $\mathrm{N}$ \\
\hline 82 & ICICI LTD & $\mathrm{N}$ & & & & & & & & & & \\
\hline 83 & IDBI BANK LTD. & & & J & J & J & J & J & J & J & J & J \\
\hline 84 & IDEA CELLULAR LTD. & & & & & & & $\mathrm{N}$ & $\mathrm{N}$ & $\mathrm{N}$ & & J \\
\hline 85 & IFCI LTD. & J & J & J & J & $\mathrm{J}$ & J & J & J & J & J & J \\
\hline 86 & INDIA CEMENTS LTD & J & J & J & & & & & & & & \\
\hline 87 & INDIABULLS REAL ESTATE LTD. & & & & & & & & & J & J & \\
\hline 88 & INDIAN HOTELS CO. LTD. & $\mathrm{N}$ & $\mathrm{N}$ & $\mathrm{N}$ & N & & J & J & J & J & J & J \\
\hline 89 & INDIAN OVERSEAS BANK & & & & J & J & J & J & J & J & J & $\mathrm{J}$ \\
\hline 90 & INDIAN PETROCHEMICALS CORPORATION LTD. & $\mathrm{N}$ & $\mathrm{N}$ & $\mathrm{N}$ & $\mathrm{N}$ & N & $\mathrm{N}$ & & & & & \\
\hline 91 & INDO GULF CORPORATION LTD & J & J & & & & & & & & & \\
\hline 92 & INDUSIND BANK LTD. & & & & & & & & & & & $\mathrm{J}$ \\
\hline 93 & INFOSYS LTD. & $\mathrm{N}$ & $\mathrm{N}$ & $\mathrm{N}$ & $\mathrm{N}$ & N & N & $\mathrm{N}$ & $\mathrm{N}$ & $\mathrm{N}$ & N & $\mathrm{N}$ \\
\hline 94 & INFRASTRUCTURE DEVELOPMENT FINANCE CO. LTD. & & & & & & J & J & J & $\mathrm{N}$ & $\mathrm{N}$ & $\mathrm{N}$ \\
\hline
\end{tabular}




\begin{tabular}{|c|c|c|c|c|c|c|c|c|c|c|c|c|}
\hline S.No & Name of Company & 2001 & 2002 & 2003 & 2004 & 2005 & 2006 & 2007 & 2008 & 2009 & 2010 & 2011 \\
\hline 95 & ING VYSYA BANK LTD. & J & J & J & J & $\mathrm{J}$ & J & J & J & & & \\
\hline 96 & INGERSOLL RAND (INDIA) LTD. & J & J & J & J & J & J & & & & & \\
\hline 97 & ITC HOTELS LTD & J & & & & & & & & & & \\
\hline 98 & JAIPRAKASH ASSOCIATES LTD. & & & & $\mathrm{J}$ & $\mathrm{J}$ & J & J & J & N & N & N \\
\hline 99 & JET AIRWAYS (INDIA) LTD. & & & & & $\mathrm{N}$ & $\mathrm{N}$ & & & & & \\
\hline 100 & JINDAL STEEL \& POWER LTD. & & & & & & & & J & $\mathrm{N}$ & $\mathrm{N}$ & $\mathrm{N}$ \\
\hline 101 & JINDAL VIJAYANAGAR STEEL & & & & J & & & & & & & \\
\hline 102 & JSW STEEL LTD. & & & & & & & & J & J & J & J \\
\hline 103 & KNOLL PHARMACEUTICALS LTD & J & J & & & & & & & & & \\
\hline 104 & KOCHI REFINERIES LTD & $\mathrm{N}$ & & & J & J & & & & & & \\
\hline 105 & KOTAK MAHINDRA BANK LTD. & & J & J & J & $\mathrm{J}$ & $\mathrm{J}$ & J & J & J & $\mathrm{N}$ & $\mathrm{N}$ \\
\hline 106 & LARSEN \& TOUBRO LTD. & $\mathrm{N}$ & $\mathrm{N}$ & $\mathrm{N}$ & N & $\mathrm{N}$ & $\mathrm{N}$ & $\mathrm{N}$ & $\mathrm{N}$ & $\mathrm{N}$ & $\mathrm{N}$ & $\mathrm{N}$ \\
\hline 107 & LIC HOUSING FINANCE LTD. & $\mathrm{J}$ & J & J & J & J & $\mathrm{J}$ & J & J & J & J & J \\
\hline 108 & LUPIN LTD. & & & & J & $\mathrm{J}$ & J & J & J & J & J & J \\
\hline 109 & MADRAS CEMENTS LTD & J & J & & & & & & & & & \\
\hline 110 & MAHANAGAR TELEPHONE NIGAM LTD. & $\mathrm{N}$ & $\mathrm{N}$ & $\mathrm{N}$ & $\mathrm{N}$ & N & $\mathrm{N}$ & & & & & \\
\hline 111 & MAHINDRA \& MAHINDRA LTD. & $\mathrm{N}$ & $\mathrm{N}$ & $\mathrm{N}$ & $\mathrm{N}$ & N & $\mathrm{N}$ & $\mathrm{N}$ & $\mathrm{N}$ & $\mathrm{N}$ & $\mathrm{N}$ & $\mathrm{N}$ \\
\hline 112 & MANGALORE REFINERY \& PETROCHEMICALS LTD. & & & & & & & & & J & J & \\
\hline 113 & MARUTI SUZUKI INDIA LTD. & & & & $\mathrm{N}$ & N & $\mathrm{N}$ & $\mathrm{N}$ & $\mathrm{N}$ & $\mathrm{N}$ & $\mathrm{N}$ & $\mathrm{N}$ \\
\hline 114 & MOREPEN LAB. LTD & & J & J & & & & & & & & \\
\hline 115 & MOSER BAER INDIA LTD. & & J & J & J & $\mathrm{J}$ & J & $\mathrm{J}$ & J & J & & \\
\hline 116 & MPHASIS LTD. & & & J & J & J & J & J & J & J & J & J \\
\hline 117 & NAGARJUNA FERTILIZERS LTD & J & & & & & & & & & & \\
\hline 118 & NATIONAL ALUMINIUM CO. LTD. & & & $\mathrm{N}$ & $\mathrm{N}$ & N & $\mathrm{N}$ & $\mathrm{N}$ & $\mathrm{N}$ & & & \\
\hline 119 & NESTLE INDIA LTD & $\mathrm{N}$ & $\mathrm{N}$ & & & & & & & & & \\
\hline 120 & NIIT LTD & $\mathrm{N}$ & $\mathrm{N}$ & $\mathrm{N}$ & & & & & & & & \\
\hline 121 & NIRMA LTD & & & J & J & J & J & $\mathrm{J}$ & J & & & \\
\hline 122 & NOVARTIS INDIA LTD. & $\mathrm{N}$ & $\mathrm{N}$ & & & & & & & & & \\
\hline 123 & NTPC LTD. & & & & & & & $\mathrm{N}$ & $\mathrm{N}$ & $\mathrm{N}$ & $\mathrm{N}$ & N \\
\hline 124 & OIL \& NATURAL GAS CORPORATION LTD. & & & & N & N & N & $\mathrm{N}$ & $\mathrm{N}$ & $\mathrm{N}$ & $\mathrm{N}$ & $\mathrm{N}$ \\
\hline 125 & ORACLE FINANCIAL SERVICES SOFTWARE LTD. & & & J & J & J & J & $\mathrm{J}$ & J & J & J & J \\
\hline 126 & ORCHID CHEMICALS LTD & J & J & & & & & & & & & \\
\hline 127 & ORIENTAL BANK OF COMMERCE & $\mathrm{N}$ & $\mathrm{N}$ & $\mathrm{N}$ & $\mathrm{N}$ & N & $\mathrm{N}$ & & & & & \\
\hline 128 & PATNI COMPUTER SYSTEMS LTD. & & & & J & J & J & $\mathrm{J}$ & J & J & J & \\
\hline 129 & PENTAMEDIA GRAPHICS LTD & J & J & & & & & & & & & \\
\hline 130 & PFIZER LTD. & J & J & J & J & J & J & J & & & & \\
\hline 131 & PHILIPS INDIA LTD & J & & & & & & & & & & \\
\hline 132 & PIRAMAL HEALTHCARE LTD. & J & J & J & J & $\mathrm{J}$ & J & J & & & & \\
\hline
\end{tabular}




\begin{tabular}{|c|c|c|c|c|c|c|c|c|c|c|c|c|}
\hline S.No & Name of Company & 2001 & 2002 & 2003 & 2004 & 2005 & 2006 & 2007 & 2008 & 2009 & 2010 & 2011 \\
\hline 133 & POLARIS FINANCIAL TECHNOLOGY LTD. & & J & J & J & J & J & & & & & \\
\hline 134 & POWER FINANCE CORPORATION LTD. & & & & & & & J & J & J & J & J \\
\hline 135 & POWER GRID CORPORATION OF INDIA LTD. & & & & & & & & $\mathrm{N}$ & $\mathrm{N}$ & $\mathrm{N}$ & N \\
\hline 136 & PROCTOR \& GAMBLE LTD & $\mathrm{N}$ & & & & & & & & & & \\
\hline 137 & PUNJ LLOYD LTD. & & & & & & & & & & J & \\
\hline 138 & PUNJAB NATIONAL BANK & & & J & $\mathrm{N}$ & N & N & $\mathrm{N}$ & $\mathrm{N}$ & N & N & $\mathrm{N}$ \\
\hline 139 & PUNJAB TRACTORS LTD. & J & J & J & J & J & J & J & & & & \\
\hline 140 & RANBAXY LABORATORIES LTD. & $\mathrm{N}$ & $\mathrm{N}$ & $\mathrm{N}$ & $\mathrm{N}$ & N & N & $\mathrm{N}$ & $\mathrm{N}$ & $\mathrm{N}$ & $\mathrm{N}$ & $\mathrm{N}$ \\
\hline 141 & RAYMOND LTD. & J & J & J & J & J & J & J & $\mathrm{J}$ & & & \\
\hline 142 & RECKITT BENCKISER (I) LTD & $\mathrm{N}$ & & & & & & & & & & \\
\hline 143 & RELIANCE CAPITAL LTD. & & & & & & J & J & J & $\mathrm{N}$ & $\mathrm{N}$ & J \\
\hline 144 & RELIANCE COMMUNICATIONS LTD. & & & & & & $\mathrm{N}$ & $\mathrm{N}$ & $\mathrm{N}$ & $\mathrm{N}$ & $\mathrm{N}$ & $\mathrm{N}$ \\
\hline 145 & RELIANCE INDUSTRIES LTD. & $\mathrm{N}$ & $\mathrm{N}$ & $\mathrm{N}$ & $\mathrm{N}$ & $\mathrm{N}$ & $\mathrm{N}$ & $\mathrm{N}$ & $\mathrm{N}$ & $\mathrm{N}$ & $\mathrm{N}$ & N \\
\hline 146 & RELIANCE INFRASTRUCTURE LTD. & $\mathrm{N}$ & $\mathrm{N}$ & $\mathrm{N}$ & $\mathrm{N}$ & $\mathrm{N}$ & $\mathrm{N}$ & $\mathrm{N}$ & $\mathrm{N}$ & $\mathrm{N}$ & $\mathrm{N}$ & $\mathrm{N}$ \\
\hline 147 & RELIANCE NATURAL RESOURCES LTD. & & & & & & & & J & J & & \\
\hline 148 & RELIANCE PETROLEUM LTD. & $\mathrm{N}$ & & & & & J & $\mathrm{N}$ & $\mathrm{N}$ & & & \\
\hline 149 & RELIANCE POWER LTD. & & & & & & & & $\mathrm{N}$ & $\mathrm{N}$ & N & $\mathrm{N}$ \\
\hline 150 & ROLTA INDIA LTD & J & J & J & & & & & & & & \\
\hline 151 & RURAL ELECTRIFICATION CORPORATION LTD. & & & & & & & & & & J & J \\
\hline 152 & SATYAM COMPUTER SERVICES LTD. & $\mathrm{N}$ & $\mathrm{N}$ & $\mathrm{N}$ & $\mathrm{N}$ & N & $\mathrm{N}$ & $\mathrm{N}$ & $\mathrm{N}$ & & & \\
\hline 153 & SESA GOA LTD. & & & & & & & & & J & N & $\mathrm{N}$ \\
\hline 154 & SHIPPING CORPORATION OF INDIA LTD. & & $\mathrm{N}$ & $\mathrm{N}$ & $\mathrm{N}$ & N & & & & & & \\
\hline 155 & SHRIRAM TRANSPORT FINANCE CO. LTD. & & & & & & & & & & J & J \\
\hline 156 & SIEMENS LTD. & J & J & J & J & $\mathrm{J}$ & $\mathrm{N}$ & $\mathrm{N}$ & $\mathrm{N}$ & $\mathrm{N}$ & $\mathrm{N}$ & $\mathrm{N}$ \\
\hline 157 & SILVERLINE TECHNOLOGIES L & J & J & & & & & & & & & \\
\hline 158 & SPIC LTD & J & & & & & & & & & & \\
\hline 159 & STATE BANK OF INDIA & $\mathrm{N}$ & $\mathrm{N}$ & $\mathrm{N}$ & $\mathrm{N}$ & N & $\mathrm{N}$ & $\mathrm{N}$ & $\mathrm{N}$ & $\mathrm{N}$ & $\mathrm{N}$ & $\mathrm{N}$ \\
\hline 160 & STEEL AUTHORITY OF INDIA LTD. & & & $\mathrm{N}$ & N & N & $\mathrm{N}$ & $\mathrm{N}$ & $\mathrm{N}$ & $\mathrm{N}$ & $\mathrm{N}$ & N \\
\hline 161 & STERLITE INDUSTRIES (INDIA) LTD. & & & & & $\mathrm{J}$ & J & $\mathrm{N}$ & $\mathrm{N}$ & $\mathrm{N}$ & $\mathrm{N}$ & $\mathrm{N}$ \\
\hline 162 & SUN PHARMACEUTICAL INDUSTRIES LTD. & J & $\mathrm{N}$ & $\mathrm{N}$ & $\mathrm{N}$ & N & $\mathrm{N}$ & $\mathrm{N}$ & $\mathrm{N}$ & $\mathrm{N}$ & $\mathrm{N}$ & $\mathrm{N}$ \\
\hline 163 & SUZLON ENERGY LTD. & & & & & & $\mathrm{N}$ & $\mathrm{N}$ & $\mathrm{N}$ & $\mathrm{N}$ & N & \\
\hline 164 & SYNDICATE BANK & & & & J & J & J & J & J & J & J & \\
\hline 165 & TATA CHEMICALS LTD. & $\mathrm{N}$ & $\mathrm{N}$ & $\mathrm{N}$ & N & N & & & & & J & J \\
\hline 166 & TATA COMMUNICATIONS LTD. & & $\mathrm{N}$ & $\mathrm{N}$ & $\mathrm{N}$ & N & $\mathrm{N}$ & $\mathrm{N}$ & $\mathrm{N}$ & & & \\
\hline 167 & TATA CONSULTANCY SERVICES LTD. & & & & & N & N & $\mathrm{N}$ & $\mathrm{N}$ & N & N & N \\
\hline 168 & TATA GLOBAL BEVERAGES LTD. & $\mathrm{N}$ & $\mathrm{N}$ & $\mathrm{N}$ & N & N & & & & & & \\
\hline 169 & TATA INFOTECH LTD. & J & J & & & & & & & & & \\
\hline 170 & TATA MOTORS LTD. & $\mathrm{N}$ & $\mathrm{N}$ & $\mathrm{N}$ & $\mathrm{N}$ & $\mathrm{N}$ & $\mathrm{N}$ & $\mathrm{N}$ & $\mathrm{N}$ & $\mathrm{N}$ & $\mathrm{N}$ & $\mathrm{N}$ \\
\hline
\end{tabular}




\begin{tabular}{|c|c|c|c|c|c|c|c|c|c|c|c|c|}
\hline S.No & Name of Company & 2001 & 2002 & 2003 & 2004 & 2005 & 2006 & 2007 & 2008 & 2009 & 2010 & 2011 \\
\hline 171 & TATA POWER CO. LTD. & $\mathrm{N}$ & $\mathrm{N}$ & $\mathrm{N}$ & $\mathrm{N}$ & $\mathrm{N}$ & $\mathrm{N}$ & $\mathrm{N}$ & $\mathrm{N}$ & $\mathrm{N}$ & $\mathrm{N}$ & $\mathrm{N}$ \\
\hline 172 & TATA STEEL LTD. & $\mathrm{N}$ & $\mathrm{N}$ & $\mathrm{N}$ & $\mathrm{N}$ & $\mathrm{N}$ & $\mathrm{N}$ & $\mathrm{N}$ & $\mathrm{N}$ & $\mathrm{N}$ & $\mathrm{N}$ & $\mathrm{N}$ \\
\hline 173 & TATA TELESERVICES (MAHARASHTRA) LTD. & & & J & J & $\mathrm{J}$ & J & J & $\mathrm{J}$ & J & & \\
\hline 174 & TECH MAHINDRA LTD. & & & & & & & $\mathrm{J}$ & $\mathrm{J}$ & $\mathrm{J}$ & $\mathrm{J}$ & $\mathrm{J}$ \\
\hline 175 & THOMAS COOK (INDIA) LTD & $\mathrm{J}$ & J & J & & & & & & & & \\
\hline 176 & TITAN INDUSTRIES LTD. & J & J & J & & & & & & & & J \\
\hline 177 & TORRENT POWER LTD. & & & & & & & & & & $\mathrm{J}$ & J \\
\hline 178 & TVS MOTOR COMPANY LTD. & & & J & $\mathrm{J}$ & J & J & $\mathrm{J}$ & & & & \\
\hline 179 & ULTRATECH CEMENT LTD. & & & & & & & J & J & $\mathrm{J}$ & J & J \\
\hline 180 & UNION BANK OF INDIA & & & J & J & $\mathrm{J}$ & $\mathrm{J}$ & $\mathrm{J}$ & J & $\mathrm{J}$ & J & J \\
\hline 181 & UNITECH LTD. & & & & & & & $\mathrm{N}$ & $\mathrm{N}$ & $\mathrm{N}$ & & \\
\hline 182 & UNITED PHOSPHORUS LTD. & J & & & & & & & & $\mathrm{J}$ & $\mathrm{J}$ & $\mathrm{J}$ \\
\hline 183 & UNITED SPIRITS LTD. & & & & & & & $\mathrm{J}$ & $\mathrm{J}$ & $\mathrm{J}$ & $\mathrm{J}$ & J \\
\hline 184 & VIJAYA BANK & & & & $\mathrm{J}$ & $\mathrm{J}$ & $\mathrm{J}$ & $\mathrm{J}$ & $\mathrm{J}$ & & & \\
\hline 185 & WARTSILA INDIA LTD & J & & & & & & & & & & \\
\hline 186 & WIPRO LTD. & & $\mathrm{N}$ & $\mathrm{N}$ & $\mathrm{N}$ & $\mathrm{N}$ & $\mathrm{N}$ & $\mathrm{N}$ & $\mathrm{N}$ & $\mathrm{N}$ & $\mathrm{N}$ & $\mathrm{N}$ \\
\hline 187 & WOCKHARDT LTD. & & J & J & $\mathrm{J}$ & J & J & J & J & & & \\
\hline 188 & YES BANK LTD. & & & & & & & & & & J & $\mathrm{J}$ \\
\hline 189 & ZEE ENTERTAINMENT ENTERPRISES LTD. & $\mathrm{N}$ & $\mathrm{N}$ & $\mathrm{N}$ & $\mathrm{N}$ & $\mathrm{N}$ & $\mathrm{N}$ & $\mathrm{N}$ & $\mathrm{N}$ & $\mathrm{J}$ & & $\mathrm{J}$ \\
\hline
\end{tabular}

\begin{tabular}{|l|l|l|l|l|l|l|l|l|l|l|l|l|}
\hline S. & & $\mathbf{2}$ & $\mathbf{2}$ & $\mathbf{2}$ & $\mathbf{2}$ & $\mathbf{2}$ & $\mathbf{2}$ & $\mathbf{2}$ & $\mathbf{2}$ & $\mathbf{2}$ & $\mathbf{2}$ & $\mathbf{2}$ \\
$\mathbf{N}$ & $\mathbf{0}$ & $\mathbf{0}$ & $\mathbf{0}$ & $\mathbf{0}$ & $\mathbf{0}$ & $\mathbf{0}$ & $\mathbf{0}$ & $\mathbf{0}$ & $\mathbf{0}$ & $\mathbf{0}$ & $\mathbf{0}$ \\
$\mathbf{0}$ & Name of Company & $\mathbf{0}$ & $\mathbf{0}$ & $\mathbf{0}$ & $\mathbf{0}$ & $\mathbf{0}$ & $\mathbf{0}$ & $\mathbf{0}$ & $\mathbf{0}$ & $\mathbf{0}$ & $\mathbf{1}$ & $\mathbf{1}$ \\
\hline 1 & ABB LTD. & $\mathrm{N}$ & $\mathrm{N}$ & $\mathrm{N}$ & $\mathrm{N}$ & $\mathrm{N}$ & $\mathrm{N}$ & $\mathrm{N}$ & $\mathrm{N}$ & $\mathrm{N}$ & & \\
\hline 2 & ACC LTD. & $\mathrm{N}$ & $\mathrm{N}$ & $\mathrm{N}$ & $\mathrm{N}$ & $\mathrm{N}$ & $\mathrm{N}$ & $\mathrm{N}$ & $\mathrm{N}$ & $\mathrm{N}$ & $\mathrm{N}$ & $\mathrm{N}$ \\
\hline 3 & ADANI ENTERPRISES LTD. & & & & & & & & & $\mathrm{S}$ & $\mathrm{S}$ & $\mathrm{S}$ \\
\hline & ADANI PORTS AND & & & & & & & & & & & \\
& SPECIAL ECONOMIC & & & & & & & & & & & \\
\hline & ZONE LTD. & & & & & & & & $\mathrm{S}$ & $\mathrm{S}$ & $\mathrm{S}$ & $\mathrm{S}$ \\
\hline 5 & ADITYA BIRLA NUVO LTD. & & & & & & & $\mathrm{S}$ & $\mathrm{S}$ & $\mathrm{S}$ & $\mathrm{S}$ & $\mathrm{S}$ \\
\hline 6 & AMBUIA CEMENTS LTD. & $\mathrm{N}$ & $\mathrm{N}$ & $\mathrm{N}$ & $\mathrm{N}$ & $\mathrm{N}$ & $\mathrm{N}$ & $\mathrm{N}$ & $\mathrm{N}$ & $\mathrm{N}$ & $\mathrm{N}$ & $\mathrm{N}$ \\
\hline 7 & ANDHRA BANK & & & $\mathrm{S}$ & $\mathrm{S}$ & $\mathrm{S}$ & $\mathrm{S}$ & $\mathrm{S}$ & $\mathrm{S}$ & $\mathrm{S}$ & $\mathrm{S}$ & $\mathrm{S}$ \\
\hline 8 & APOLLO TYRES LTD. & $\mathrm{S}$ & $\mathrm{S}$ & $\mathrm{S}$ & $\mathrm{S}$ & $\mathrm{S}$ & $\mathrm{S}$ & $\mathrm{S}$ & $\mathrm{S}$ & & & \\
\hline 9 & APTECH LTD. & $\mathrm{S}$ & & & & & & & & & & \\
\hline 1 & & & & & & & & & & & & \\
0 & ASHOK LEYLAND LTD. & $\mathrm{S}$ & $\mathrm{S}$ & $\mathrm{S}$ & $\mathrm{S}$ & $\mathrm{S}$ & $\mathrm{S}$ & $\mathrm{S}$ & $\mathrm{S}$ & $\mathrm{S}$ & $\mathrm{S}$ & $\mathrm{S}$ \\
\hline 1 & & & & & & & & & & & & \\
1 & ASIAN PAINTS INDIA LTD & $\mathrm{N}$ & & & & & & & & & & \\
\hline
\end{tabular}




\begin{tabular}{|c|c|c|c|c|c|c|c|c|c|c|c|c|}
\hline $\begin{array}{l}1 \\
2\end{array}$ & ASIAN PAINTS LTD. & & & $\mathrm{S}$ & $\mathrm{S}$ & $\mathrm{S}$ & $\mathrm{S}$ & $\mathrm{S}$ & $\mathrm{S}$ & $\mathrm{S}$ & $\mathrm{S}$ & $\mathrm{s}$ \\
\hline $\begin{array}{l}1 \\
3\end{array}$ & $\begin{array}{l}\text { AUROBINDO PHARMA } \\
\text { LTD. }\end{array}$ & $\mathrm{S}$ & $\mathrm{S}$ & $\mathrm{S}$ & $\mathrm{S}$ & $\mathrm{S}$ & $\mathrm{S}$ & $\mathrm{S}$ & & & & \\
\hline $\begin{array}{l}1 \\
4\end{array}$ & AVENTIS PHARMA LTD. & & $S$ & $S$ & $S$ & $S$ & $S$ & $S$ & $S$ & & & \\
\hline $\begin{array}{l}1 \\
5\end{array}$ & AXIS BANK LTD. & & & $S$ & $S$ & $S$ & $S$ & $\mathrm{~S}$ & $\mathrm{~S}$ & $\mathrm{~N}$ & $\mathrm{~N}$ & $\mathrm{~N}$ \\
\hline $\begin{array}{l}1 \\
6\end{array}$ & BAJAJ AUTO LTD. & $\mathrm{N}$ & $\mathrm{N}$ & $\mathrm{N}$ & $\mathrm{N}$ & $\mathrm{N}$ & $\mathrm{N}$ & $\mathrm{N}$ & & $\mathrm{S}$ & $\mathrm{N}$ & $\mathrm{N}$ \\
\hline $\begin{array}{l}1 \\
7\end{array}$ & BANK OF BARODA & $\mathrm{S}$ & $\mathrm{S}$ & $\mathrm{S}$ & $\mathrm{S}$ & $\mathrm{S}$ & $\mathrm{S}$ & $\mathrm{S}$ & $\mathrm{S}$ & $\mathrm{S}$ & $\mathrm{S}$ & $S$ \\
\hline $\begin{array}{l}1 \\
8\end{array}$ & BANK OF INDIA & & $\mathrm{S}$ & $\mathrm{S}$ & $\mathrm{S}$ & $\mathrm{S}$ & $\mathrm{S}$ & $\mathrm{S}$ & $\mathrm{S}$ & $\mathrm{S}$ & $\mathrm{S}$ & $S$ \\
\hline $\begin{array}{l}1 \\
9\end{array}$ & BATA INDIA LTD & $\mathrm{S}$ & & & & & & & & & & \\
\hline $\begin{array}{l}2 \\
0\end{array}$ & $\begin{array}{l}\text { BHARAT ELECTRONICS } \\
\text { LTD. }\end{array}$ & & $\mathrm{S}$ & $\mathrm{S}$ & $\mathrm{S}$ & $\mathrm{S}$ & $\mathrm{S}$ & $\mathrm{S}$ & $\mathrm{S}$ & $S$ & $\mathrm{~S}$ & $S$ \\
\hline $\begin{array}{l}2 \\
1\end{array}$ & BHARAT FORGE LTD. & & & & $\mathrm{S}$ & $\mathrm{S}$ & $S$ & $\mathrm{~S}$ & $S$ & $S$ & $\mathrm{~S}$ & $\mathrm{~S}$ \\
\hline $\begin{array}{l}2 \\
2\end{array}$ & $\begin{array}{l}\text { BHARAT HEAVY } \\
\text { ELECTRICALS LTD. }\end{array}$ & $\mathrm{N}$ & $\mathrm{N}$ & $\mathrm{N}$ & $\mathrm{N}$ & $\mathrm{N}$ & $\mathrm{N}$ & $\mathrm{N}$ & $\mathrm{N}$ & $\mathrm{N}$ & $\mathrm{N}$ & $\mathrm{N}$ \\
\hline $\begin{array}{l}2 \\
3\end{array}$ & $\begin{array}{l}\text { BHARAT PETROLEUM } \\
\text { CORPORATION LTD. }\end{array}$ & & $\mathrm{N}$ & $\mathrm{N}$ & $\mathrm{N}$ & $\mathrm{N}$ & $\mathrm{N}$ & $\mathrm{N}$ & $\mathrm{N}$ & $\mathrm{N}$ & $\mathrm{N}$ & $\mathrm{N}$ \\
\hline $\begin{array}{l}2 \\
4\end{array}$ & BHARTI AIRTEL LTD. & & & $\mathrm{S}$ & $\mathrm{N}$ & $\mathrm{N}$ & $\mathrm{N}$ & $\mathrm{N}$ & $\mathrm{N}$ & $\mathrm{N}$ & $\mathrm{N}$ & $\mathrm{N}$ \\
\hline $\begin{array}{l}2 \\
5\end{array}$ & BIOCON LTD. & & & & $\mathrm{S}$ & $\mathrm{S}$ & $\mathrm{S}$ & $\mathrm{S}$ & $\mathrm{S}$ & $\mathrm{S}$ & $\mathrm{S}$ & S \\
\hline $\begin{array}{l}2 \\
6\end{array}$ & $\begin{array}{l}\text { BOMBAY DYEING \& MFG. } \\
\text { CO L }\end{array}$ & $\mathrm{S}$ & & & & & & & & & & \\
\hline $\begin{array}{l}2 \\
7\end{array}$ & $\begin{array}{l}\text { BONGAIGAON REFINERY } \\
\text { \& PETROCHEMICALS LTD. }\end{array}$ & & & & $\mathrm{S}$ & $\mathrm{S}$ & $\mathrm{S}$ & & & & & \\
\hline $\begin{array}{l}2 \\
8\end{array}$ & BOSCH LTD. & & & & & & & & & & & $S$ \\
\hline $\begin{array}{l}2 \\
9\end{array}$ & $\begin{array}{l}\text { BRITANNIA INDUSTRIES } \\
\text { LTD }\end{array}$ & $\mathrm{N}$ & $\mathrm{N}$ & $\mathrm{N}$ & & & & & & & & \\
\hline $\begin{array}{l}3 \\
0\end{array}$ & BURROUGHS WELLCOME & $\mathrm{S}$ & & & & & & & & & & \\
\hline $\begin{array}{l}3 \\
1\end{array}$ & CADBURY INDIA LTD & $\mathrm{S}$ & & & & & & & & & & \\
\hline $\begin{array}{l}3 \\
2\end{array}$ & $\begin{array}{l}\text { CADILA HEALTHCARE } \\
\text { LTD. }\end{array}$ & & & & $\mathrm{S}$ & $\mathrm{S}$ & $\mathrm{S}$ & $\mathrm{S}$ & & & & \\
\hline $\begin{array}{l}3 \\
3\end{array}$ & CAIRN INDIA LTD. & & & & & & & $\mathrm{N}$ & $\mathrm{N}$ & $\mathrm{N}$ & $\mathrm{N}$ & $\mathrm{N}$ \\
\hline
\end{tabular}




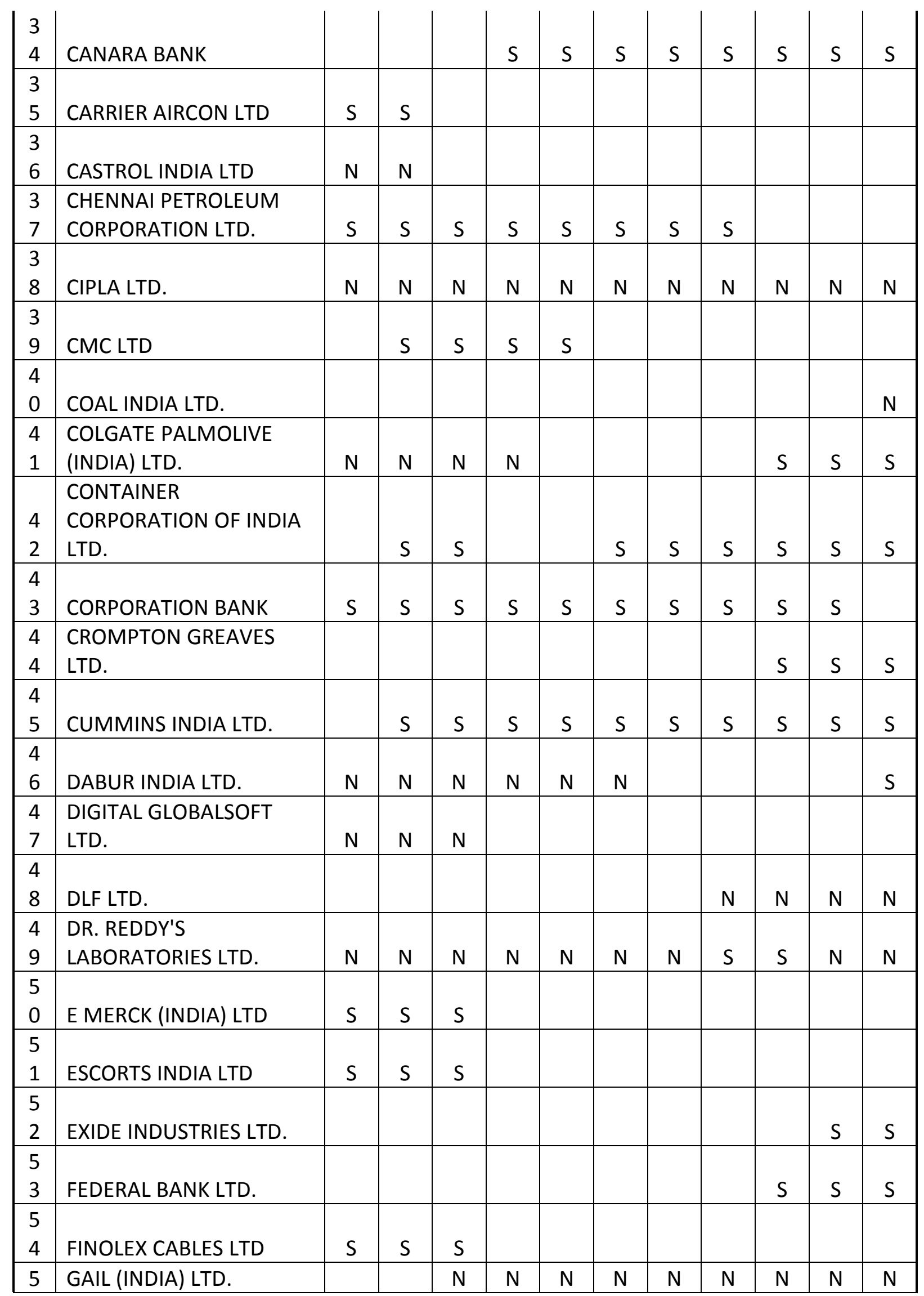




\begin{tabular}{|c|c|c|c|c|c|c|c|c|c|c|c|c|}
\hline 5 & & & & & & & & & & & & \\
\hline $\begin{array}{l}5 \\
6\end{array}$ & GERMAN REMEDIES LTD & $\mathrm{S}$ & $\mathrm{S}$ & & & & & & & & & \\
\hline $\begin{array}{l}5 \\
7\end{array}$ & GILLETTE INDIA LTD & $\mathrm{S}$ & $\mathrm{S}$ & & & & & & & & & \\
\hline $\begin{array}{l}5 \\
8\end{array}$ & $\begin{array}{l}\text { GLAXOSMITHKLINE } \\
\text { CONSUMER }\end{array}$ & $\mathrm{N}$ & $\mathrm{N}$ & $\mathrm{N}$ & & & & & & & & \\
\hline $\begin{array}{l}5 \\
9\end{array}$ & $\begin{array}{l}\text { GLAXOSMITHKLINE } \\
\text { PHARMACEUTICALS LTD. }\end{array}$ & $\mathrm{N}$ & $\mathrm{N}$ & $\mathrm{N}$ & $\mathrm{N}$ & $\mathrm{N}$ & $\mathrm{N}$ & $\mathrm{N}$ & & $\mathrm{S}$ & $\mathrm{S}$ & $S$ \\
\hline $\begin{array}{l}6 \\
0\end{array}$ & $\begin{array}{l}\text { GLENMARK } \\
\text { PHARMACEUTICALS LTD. }\end{array}$ & & & & & & & & & $\mathrm{S}$ & $\mathrm{S}$ & $\mathrm{S}$ \\
\hline $\begin{array}{l}6 \\
1\end{array}$ & GLOBAL TRUST BANK LTD & $S$ & $S$ & & & & & & & & & \\
\hline $\begin{array}{l}6 \\
2\end{array}$ & $\begin{array}{l}\text { GMR INFRASTRUCTURE } \\
\text { LTD. }\end{array}$ & & & & & & & $S$ & $S$ & $S$ & $\mathrm{~S}$ & $\mathrm{~S}$ \\
\hline $\begin{array}{l}6 \\
3\end{array}$ & GRASIM INDUSTRIES LTD. & $\mathrm{N}$ & $\mathrm{N}$ & $\mathrm{N}$ & $\mathrm{N}$ & $\mathrm{N}$ & $\mathrm{N}$ & $\mathrm{N}$ & $\mathrm{N}$ & $\mathrm{N}$ & $S$ & $\mathrm{~N}$ \\
\hline $\begin{array}{l}6 \\
4\end{array}$ & $\begin{array}{l}\text { GREAT EASTERN } \\
\text { SHIPPING CO }\end{array}$ & $\mathrm{S}$ & $\mathrm{S}$ & $\mathrm{S}$ & $S$ & $\mathrm{~S}$ & & & & & & \\
\hline $\begin{array}{l}6 \\
5\end{array}$ & GTL LTD & & $\mathrm{S}$ & $\mathrm{S}$ & & & & & & & & \\
\hline $\begin{array}{l}6 \\
6\end{array}$ & HCL INFOSYSTEMS LTD & $\mathrm{N}$ & & & & & & & & & & \\
\hline $\begin{array}{l}6 \\
7\end{array}$ & HCL TECHNOLOGIES LTD. & & $\mathrm{N}$ & $\mathrm{N}$ & $\mathrm{N}$ & $\mathrm{N}$ & $\mathrm{N}$ & $\mathrm{N}$ & $\mathrm{N}$ & $\mathrm{N}$ & $\mathrm{N}$ & $\mathrm{N}$ \\
\hline $\begin{array}{l}6 \\
8\end{array}$ & HDFC BANK LTD. & $\mathrm{N}$ & $\mathrm{N}$ & $\mathrm{N}$ & $\mathrm{N}$ & $\mathrm{N}$ & $\mathrm{N}$ & $\mathrm{N}$ & $\mathrm{N}$ & $\mathrm{N}$ & $\mathrm{N}$ & $\mathrm{N}$ \\
\hline $\begin{array}{l}6 \\
9\end{array}$ & HERO MOTOCORP LTD. & $\mathrm{N}$ & $\mathrm{N}$ & $\mathrm{N}$ & $\mathrm{N}$ & $\mathrm{N}$ & $\mathrm{N}$ & $\mathrm{N}$ & $\mathrm{N}$ & $\mathrm{N}$ & $\mathrm{N}$ & $\mathrm{N}$ \\
\hline $\begin{array}{l}7 \\
0\end{array}$ & $\begin{array}{l}\text { HIMACHAL FUTURISTICS } \\
\text { COMM }\end{array}$ & $S$ & $S$ & $S$ & & & & & & & & \\
\hline $\begin{array}{l}7 \\
1\end{array}$ & $\begin{array}{l}\text { HINDALCO INDUSTRIES } \\
\text { LTD. }\end{array}$ & $\mathrm{N}$ & $\mathrm{N}$ & $\mathrm{N}$ & $\mathrm{N}$ & $\mathrm{N}$ & $\mathrm{N}$ & $\mathrm{N}$ & $\mathrm{N}$ & $\mathrm{N}$ & $\mathrm{N}$ & $\mathrm{N}$ \\
\hline $\begin{array}{l}7 \\
2\end{array}$ & $\begin{array}{l}\text { HINDUSTAN PETROLEUM } \\
\text { CORPORATION LTD. }\end{array}$ & $\mathrm{N}$ & $\mathrm{N}$ & $\mathrm{N}$ & $\mathrm{N}$ & $\mathrm{N}$ & $\mathrm{N}$ & & & $S$ & $S$ & $\mathrm{~S}$ \\
\hline $\begin{array}{l}7 \\
3\end{array}$ & $\begin{array}{l}\text { HINDUSTAN UNILEVER } \\
\text { LTD. }\end{array}$ & $\mathrm{N}$ & $\mathrm{N}$ & $\mathrm{N}$ & $\mathrm{N}$ & $\mathrm{N}$ & $\mathrm{N}$ & $\mathrm{N}$ & $\mathrm{N}$ & $\mathrm{N}$ & $\mathrm{N}$ & $\mathrm{N}$ \\
\hline $\begin{array}{l}7 \\
4\end{array}$ & HINDUSTAN ZINC LTD & & $\mathrm{S}$ & & & & & & & & & \\
\hline $\begin{array}{l}7 \\
5 \\
\end{array}$ & $\begin{array}{l}\text { HOUSING DEVELOPMENT } \\
\text { AND INFRASTRUCTURE } \\
\text { LTD. }\end{array}$ & & & & & & & & $S$ & $\mathrm{~S}$ & $S$ & $\mathrm{~S}$ \\
\hline $\begin{array}{l}7 \\
6\end{array}$ & $\begin{array}{l}\text { HOUSING DEVELOPMENT } \\
\text { FINANCE CORPORATION }\end{array}$ & $\mathrm{N}$ & $\mathrm{N}$ & $\mathrm{N}$ & $\mathrm{N}$ & $\mathrm{N}$ & $\mathrm{N}$ & $\mathrm{N}$ & $\mathrm{N}$ & $\mathrm{N}$ & $\mathrm{N}$ & $\mathrm{N}$ \\
\hline
\end{tabular}




\begin{tabular}{|c|c|c|c|c|c|c|c|c|c|c|c|c|}
\hline & LTD. & & & & & & & & & & & \\
\hline $\begin{array}{l}7 \\
7\end{array}$ & $\begin{array}{l}\text { HUGHES SOFTWARE } \\
\text { SYSTEMS }\end{array}$ & $S$ & $\mathrm{~S}$ & $\mathrm{~S}$ & $\mathrm{~S}$ & $S$ & & & & & & \\
\hline $\begin{array}{l}7 \\
8\end{array}$ & I T C LTD. & $\mathrm{N}$ & $\mathrm{N}$ & $\mathrm{N}$ & $\mathrm{N}$ & $\mathrm{N}$ & $\mathrm{N}$ & $\mathrm{N}$ & $\mathrm{N}$ & $\mathrm{N}$ & $\mathrm{N}$ & $\mathrm{N}$ \\
\hline $\begin{array}{l}7 \\
9\end{array}$ & IBP CO. LTD. & & & & $\mathrm{S}$ & $\mathrm{S}$ & $\mathrm{S}$ & & & & & \\
\hline $\begin{array}{l}8 \\
0\end{array}$ & ICI INDIA LTD & $\mathrm{S}$ & $\mathrm{S}$ & $\mathrm{S}$ & & & & & & & & \\
\hline $\begin{array}{l}8 \\
1\end{array}$ & ICICI BANK LTD. & $S$ & $\mathrm{~N}$ & $\mathrm{~N}$ & $\mathrm{~N}$ & $\mathrm{~N}$ & $\mathrm{~N}$ & $\mathrm{~N}$ & $\mathrm{~N}$ & $\mathrm{~N}$ & $\mathrm{~N}$ & $\mathrm{~N}$ \\
\hline $\begin{array}{l}8 \\
2\end{array}$ & ICICI LTD & $\mathrm{N}$ & & & & & & & & & & \\
\hline $\begin{array}{l}8 \\
3\end{array}$ & IDBI BANK LTD. & & & S & $\mathrm{S}$ & S & $\mathrm{S}$ & $\mathrm{S}$ & $\mathrm{S}$ & S & $\mathrm{S}$ & $\mathrm{S}$ \\
\hline $\begin{array}{l}8 \\
4\end{array}$ & IDEA CELLULAR LTD. & & & & & & & $\mathrm{N}$ & $\mathrm{N}$ & $\mathrm{N}$ & & $S$ \\
\hline $\begin{array}{l}8 \\
5\end{array}$ & IFCI LTD. & $\mathrm{S}$ & $\mathrm{S}$ & $\mathrm{S}$ & $\mathrm{S}$ & $\mathrm{S}$ & $\mathrm{S}$ & $\mathrm{S}$ & $\mathrm{S}$ & $\mathrm{S}$ & $\mathrm{S}$ & $\mathrm{S}$ \\
\hline $\begin{array}{l}8 \\
6\end{array}$ & INDIA CEMENTS LTD & $\mathrm{S}$ & $\mathrm{S}$ & $\mathrm{S}$ & & & & & & & & \\
\hline $\begin{array}{l}8 \\
7\end{array}$ & $\begin{array}{l}\text { INDIABULLS REAL ESTATE } \\
\text { LTD. }\end{array}$ & & & & & & & & & $\mathrm{S}$ & $\mathrm{S}$ & \\
\hline $\begin{array}{l}8 \\
8\end{array}$ & INDIAN HOTELS CO. LTD. & $\mathrm{N}$ & $\mathrm{N}$ & $\mathrm{N}$ & $\mathrm{N}$ & & $S$ & $S$ & $S$ & $S$ & $S$ & $\mathrm{~S}$ \\
\hline $\begin{array}{l}8 \\
9\end{array}$ & INDIAN OVERSEAS BANK & & & & $S$ & $S$ & $S$ & $S$ & $S$ & $\mathrm{~S}$ & $S$ & $\mathrm{~S}$ \\
\hline $\begin{array}{l}9 \\
0\end{array}$ & $\begin{array}{l}\text { INDIAN } \\
\text { PETROCHEMICALS } \\
\text { CORPORATION LTD. }\end{array}$ & $\mathrm{N}$ & $\mathrm{N}$ & $\mathrm{N}$ & $\mathrm{N}$ & $\mathrm{N}$ & $\mathrm{N}$ & & & & & \\
\hline $\begin{array}{l}9 \\
1\end{array}$ & $\begin{array}{l}\text { INDO GULF } \\
\text { CORPORATION LTD }\end{array}$ & $\mathrm{S}$ & $\mathrm{S}$ & & & & & & & & & \\
\hline $\begin{array}{l}9 \\
2 \\
\end{array}$ & INDUSIND BANK LTD. & & & & & & & & & & & $\mathrm{S}$ \\
\hline $\begin{array}{l}9 \\
3\end{array}$ & INFOSYS LTD. & $\mathrm{N}$ & $\mathrm{N}$ & $\mathrm{N}$ & $\mathrm{N}$ & $\mathrm{N}$ & $\mathrm{N}$ & $\mathrm{N}$ & $\mathrm{N}$ & $\mathrm{N}$ & $\mathrm{N}$ & $\mathrm{N}$ \\
\hline $\begin{array}{l}9 \\
4\end{array}$ & $\begin{array}{l}\text { INFRASTRUCTURE } \\
\text { DEVELOPMENT FINANCE } \\
\text { CO. LTD. }\end{array}$ & & & & & & $\mathrm{S}$ & S & $\mathrm{S}$ & $\mathrm{N}$ & $\mathrm{N}$ & $\mathrm{N}$ \\
\hline $\begin{array}{l}9 \\
5\end{array}$ & ING VYSYA BANK LTD. & $\mathrm{S}$ & $\mathrm{S}$ & $\mathrm{S}$ & $\mathrm{S}$ & $\mathrm{S}$ & $\mathrm{S}$ & $\mathrm{S}$ & $\mathrm{S}$ & & & \\
\hline $\begin{array}{l}9 \\
6\end{array}$ & $\begin{array}{l}\text { INGERSOLL RAND (INDIA) } \\
\text { LTD. }\end{array}$ & $\mathrm{S}$ & $S$ & $\mathrm{~S}$ & $S$ & $\mathrm{~S}$ & $\mathrm{~S}$ & & & & & \\
\hline 9 & ITC HOTELS LTD & $S$ & & & & & & & & & & \\
\hline
\end{tabular}




\begin{tabular}{|c|c|c|c|c|c|c|c|c|c|c|c|c|}
\hline 7 & & & & & & & & & & & & \\
\hline $\begin{array}{l}9 \\
8\end{array}$ & $\begin{array}{l}\text { JAIPRAKASH ASSOCIATES } \\
\text { LTD. }\end{array}$ & & & & $S$ & $S$ & $S$ & $S$ & $S$ & $\mathrm{~N}$ & $\mathrm{~N}$ & $\mathrm{~N}$ \\
\hline $\begin{array}{l}9 \\
9\end{array}$ & JET AIRWAYS (INDIA) LTD. & & & & & $\mathrm{N}$ & $\mathrm{N}$ & & & & & \\
\hline $\begin{array}{l}1 \\
0 \\
0\end{array}$ & $\begin{array}{l}\text { JINDAL STEEL \& POWER } \\
\text { LTD. }\end{array}$ & & & & & & & & $S$ & $\mathrm{~N}$ & $\mathrm{~N}$ & $\mathrm{~N}$ \\
\hline $\begin{array}{l}1 \\
0 \\
1\end{array}$ & $\begin{array}{l}\text { JINDAL VIJAYANAGAR } \\
\text { STEEL }\end{array}$ & & & & $S$ & & & & & & & \\
\hline $\begin{array}{l}1 \\
0 \\
2\end{array}$ & JSW STEEL LTD. & & & & & & & & $S$ & $S$ & $S$ & $\mathrm{~S}$ \\
\hline $\begin{array}{l}1 \\
0 \\
3\end{array}$ & $\begin{array}{l}\text { KNOLL } \\
\text { PHARMACEUTICALS LTD }\end{array}$ & $S$ & $S$ & & & & & & & & & \\
\hline $\begin{array}{l}1 \\
0 \\
4\end{array}$ & KOCHI REFINERIES LTD & $\mathrm{N}$ & & & $S$ & $S$ & & & & & & \\
\hline $\begin{array}{l}1 \\
0 \\
5\end{array}$ & $\begin{array}{l}\text { KOTAK MAHINDRA BANK } \\
\text { LTD. }\end{array}$ & & $S$ & $S$ & $S$ & $S$ & $S$ & $S$ & $S$ & $\mathrm{~S}$ & $\mathrm{~N}$ & $\mathrm{~N}$ \\
\hline $\begin{array}{l}1 \\
0 \\
6\end{array}$ & LARSEN \& TOUBRO LTD. & $\mathrm{N}$ & $\mathrm{N}$ & $\mathrm{N}$ & $\mathrm{N}$ & $\mathrm{N}$ & $\mathrm{N}$ & $\mathrm{N}$ & $\mathrm{N}$ & $\mathrm{N}$ & $\mathrm{N}$ & $\mathrm{N}$ \\
\hline $\begin{array}{l}1 \\
0 \\
7\end{array}$ & $\begin{array}{l}\text { LIC HOUSING FINANCE } \\
\text { LTD. }\end{array}$ & $S$ & $S$ & $S$ & $S$ & $S$ & $S$ & $S$ & $S$ & $S$ & $S$ & $S$ \\
\hline $\begin{array}{l}1 \\
0 \\
8\end{array}$ & LUPIN LTD. & & & & $S$ & $S$ & $S$ & $S$ & $S$ & $S$ & $S$ & $S$ \\
\hline $\begin{array}{l}1 \\
0 \\
9\end{array}$ & MADRAS CEMENTS LTD & $\mathrm{S}$ & $S$ & & & & & & & & & \\
\hline $\begin{array}{l}1 \\
1 \\
0\end{array}$ & $\begin{array}{l}\text { MAHANAGAR } \\
\text { TELEPHONE NIGAM LTD. }\end{array}$ & $\mathrm{N}$ & $\mathrm{N}$ & $\mathrm{N}$ & $\mathrm{N}$ & $\mathrm{N}$ & $\mathrm{N}$ & & & & & \\
\hline $\begin{array}{l}1 \\
1 \\
1\end{array}$ & $\begin{array}{l}\text { MAHINDRA \& MAHINDRA } \\
\text { LTD. }\end{array}$ & $\mathrm{N}$ & $\mathrm{N}$ & $\mathrm{N}$ & $\mathrm{N}$ & $\mathrm{N}$ & $\mathrm{N}$ & $\mathrm{N}$ & $\mathrm{N}$ & $\mathrm{N}$ & $\mathrm{N}$ & $\mathrm{N}$ \\
\hline $\begin{array}{l}1 \\
1 \\
2\end{array}$ & $\begin{array}{l}\text { MANGALORE REFINERY \& } \\
\text { PETROCHEMICALS LTD. }\end{array}$ & & & & & & & & & $S$ & $S$ & \\
\hline
\end{tabular}




\begin{tabular}{|c|c|c|c|c|c|c|c|c|c|c|c|c|}
\hline $\begin{array}{l}1 \\
1 \\
3\end{array}$ & $\begin{array}{l}\text { MARUTI SUZUKI INDIA } \\
\text { LTD. }\end{array}$ & & & & $\mathrm{N}$ & $\mathrm{N}$ & $\mathrm{N}$ & $\mathrm{N}$ & $\mathrm{N}$ & $\mathrm{N}$ & $\mathrm{N}$ & $\mathrm{N}$ \\
\hline $\begin{array}{l}1 \\
1 \\
4\end{array}$ & MOREPEN LAB. LTD & & $\mathrm{S}$ & $S$ & & & & & & & & \\
\hline $\begin{array}{l}1 \\
1 \\
5\end{array}$ & MOSER BAER INDIA LTD. & & $\mathrm{S}$ & $\mathrm{S}$ & $\mathrm{S}$ & $\mathrm{S}$ & S & $\mathrm{S}$ & S & $\mathrm{S}$ & & \\
\hline $\begin{array}{l}1 \\
1 \\
6\end{array}$ & MPHASIS LTD. & & & $\mathrm{S}$ & $\mathrm{S}$ & $\mathrm{S}$ & $\mathrm{S}$ & $\mathrm{S}$ & $\mathrm{S}$ & $S$ & $\mathrm{~S}$ & $\mathrm{~S}$ \\
\hline $\begin{array}{l}1 \\
1 \\
7\end{array}$ & $\begin{array}{l}\text { NAGARJUNA FERTILIZERS } \\
\text { LTD }\end{array}$ & $\mathrm{S}$ & & & & & & & & & & \\
\hline $\begin{array}{l}1 \\
1 \\
8\end{array}$ & $\begin{array}{l}\text { NATIONAL ALUMINIUM } \\
\text { CO. LTD. }\end{array}$ & & & $\mathrm{N}$ & $\mathrm{N}$ & $\mathrm{N}$ & $\mathrm{N}$ & $\mathrm{N}$ & $\mathrm{N}$ & & & \\
\hline $\begin{array}{l}1 \\
1 \\
9\end{array}$ & NESTLE INDIA LTD & $\mathrm{N}$ & $\mathrm{N}$ & & & & & & & & & \\
\hline $\begin{array}{l}1 \\
2 \\
0\end{array}$ & NIIT LTD & $\mathrm{N}$ & $\mathrm{N}$ & $\mathrm{N}$ & & & & & & & & \\
\hline $\begin{array}{l}1 \\
2 \\
1\end{array}$ & NIRMA LTD & & & S & $\mathrm{S}$ & $\mathrm{S}$ & $\mathrm{S}$ & $\mathrm{S}$ & $\mathrm{S}$ & & & \\
\hline $\begin{array}{l}1 \\
2 \\
2\end{array}$ & NOVARTIS INDIA LTD. & $\mathrm{N}$ & $\mathrm{N}$ & & & & & & & & & \\
\hline $\begin{array}{l}1 \\
2 \\
3\end{array}$ & NTPC LTD. & & & & & & & $\mathrm{N}$ & $\mathrm{N}$ & $\mathrm{N}$ & $\mathrm{N}$ & $\mathrm{N}$ \\
\hline $\begin{array}{l}1 \\
2 \\
4\end{array}$ & $\begin{array}{l}\text { OIL \& NATURAL GAS } \\
\text { CORPORATION LTD. }\end{array}$ & & & & $\mathrm{N}$ & $\mathrm{N}$ & $\mathrm{N}$ & $\mathrm{N}$ & $\mathrm{N}$ & $\mathrm{N}$ & $\mathrm{N}$ & $\mathrm{N}$ \\
\hline $\begin{array}{l}1 \\
2 \\
5\end{array}$ & $\begin{array}{l}\text { ORACLE FINANCIAL } \\
\text { SERVICES SOFTWARE } \\
\text { LTD. }\end{array}$ & & & $\mathrm{S}$ & $\mathrm{S}$ & $\mathrm{S}$ & $\mathrm{S}$ & $\mathrm{S}$ & $\mathrm{S}$ & $\mathrm{S}$ & $\mathrm{S}$ & $\mathrm{S}$ \\
\hline $\begin{array}{l}1 \\
2 \\
6\end{array}$ & ORCHID CHEMICALS LTD & $\mathrm{S}$ & $\mathrm{S}$ & & & & & & & & & \\
\hline $\begin{array}{l}1 \\
2 \\
7\end{array}$ & $\begin{array}{l}\text { ORIENTAL BANK OF } \\
\text { COMMERCE }\end{array}$ & $\mathrm{N}$ & $\mathrm{N}$ & $\mathrm{N}$ & $\mathrm{N}$ & $\mathrm{N}$ & $\mathrm{N}$ & & & & & \\
\hline
\end{tabular}




\begin{tabular}{|c|c|c|c|c|c|c|c|c|c|c|c|c|}
\hline $\begin{array}{l}1 \\
2 \\
8\end{array}$ & $\begin{array}{l}\text { PATNI COMPUTER } \\
\text { SYSTEMS LTD. }\end{array}$ & & & & S & $\mathrm{S}$ & $\mathrm{S}$ & $\mathrm{S}$ & $\mathrm{S}$ & S & $\mathrm{S}$ & \\
\hline $\begin{array}{l}1 \\
2 \\
9\end{array}$ & $\begin{array}{l}\text { PENTAMEDIA GRAPHICS } \\
\text { LTD }\end{array}$ & $\mathrm{S}$ & $S$ & & & & & & & & & \\
\hline $\begin{array}{l}1 \\
3 \\
0\end{array}$ & PFIZER LTD. & $\mathrm{S}$ & $\mathrm{S}$ & $\mathrm{S}$ & $\mathrm{S}$ & $\mathrm{S}$ & $\mathrm{S}$ & $\mathrm{S}$ & & & & \\
\hline $\begin{array}{l}1 \\
3 \\
1\end{array}$ & PHILIPS INDIA LTD & $\mathrm{S}$ & & & & & & & & & & \\
\hline $\begin{array}{l}1 \\
3 \\
2\end{array}$ & $\begin{array}{l}\text { PIRAMAL HEALTHCARE } \\
\text { LTD. }\end{array}$ & $\mathrm{S}$ & $\mathrm{S}$ & $\mathrm{S}$ & $\mathrm{S}$ & $\mathrm{S}$ & $\mathrm{S}$ & $\mathrm{S}$ & & & & \\
\hline $\begin{array}{l}1 \\
3 \\
3\end{array}$ & $\begin{array}{l}\text { POLARIS FINANCIAL } \\
\text { TECHNOLOGY LTD. }\end{array}$ & & $\mathrm{S}$ & $\mathrm{S}$ & $\mathrm{S}$ & $\mathrm{S}$ & $\mathrm{S}$ & & & & & \\
\hline $\begin{array}{l}1 \\
3 \\
4\end{array}$ & $\begin{array}{l}\text { POWER FINANCE } \\
\text { CORPORATION LTD. }\end{array}$ & & & & & & & $S$ & $S$ & $\mathrm{~S}$ & $S$ & $\mathrm{~S}$ \\
\hline $\begin{array}{l}1 \\
3 \\
5\end{array}$ & $\begin{array}{l}\text { POWER GRID } \\
\text { CORPORATION OF INDIA } \\
\text { LTD. }\end{array}$ & & & & & & & & $\mathrm{N}$ & $\mathrm{N}$ & $\mathrm{N}$ & $\mathrm{N}$ \\
\hline $\begin{array}{l}1 \\
3 \\
6\end{array}$ & PROCTOR \& GAMBLE LTD & $\mathrm{N}$ & & & & & & & & & & \\
\hline $\begin{array}{l}1 \\
3 \\
7\end{array}$ & PUNJ LLOYD LTD. & & & & & & & & & & $\mathrm{S}$ & \\
\hline $\begin{array}{l}1 \\
3 \\
8\end{array}$ & PUNJAB NATIONAL BANK & & & $\mathrm{S}$ & $\mathrm{N}$ & $\mathrm{N}$ & $\mathrm{N}$ & $\mathrm{N}$ & $\mathrm{N}$ & $\mathrm{N}$ & $\mathrm{N}$ & $\mathrm{N}$ \\
\hline $\begin{array}{l}1 \\
3 \\
9\end{array}$ & PUNJAB TRACTORS LTD. & $\mathrm{S}$ & $S$ & $S$ & $S$ & $S$ & $S$ & $S$ & & & & \\
\hline $\begin{array}{l}1 \\
4 \\
0\end{array}$ & $\begin{array}{l}\text { RANBAXY LABORATORIES } \\
\text { LTD. }\end{array}$ & $\mathrm{N}$ & $\mathrm{N}$ & $\mathrm{N}$ & $\mathrm{N}$ & $\mathrm{N}$ & $\mathrm{N}$ & $\mathrm{N}$ & $\mathrm{N}$ & $\mathrm{N}$ & $\mathrm{N}$ & $\mathrm{N}$ \\
\hline $\begin{array}{l}1 \\
4 \\
1\end{array}$ & RAYMOND LTD. & $\mathrm{S}$ & $\mathrm{S}$ & $\mathrm{S}$ & $\mathrm{S}$ & $\mathrm{S}$ & $\mathrm{S}$ & $\mathrm{S}$ & $\mathrm{S}$ & & & \\
\hline $\begin{array}{l}1 \\
4 \\
2\end{array}$ & $\begin{array}{l}\text { RECKITT BENCKISER (I) } \\
\text { LTD }\end{array}$ & $\mathrm{N}$ & & & & & & & & & & \\
\hline
\end{tabular}




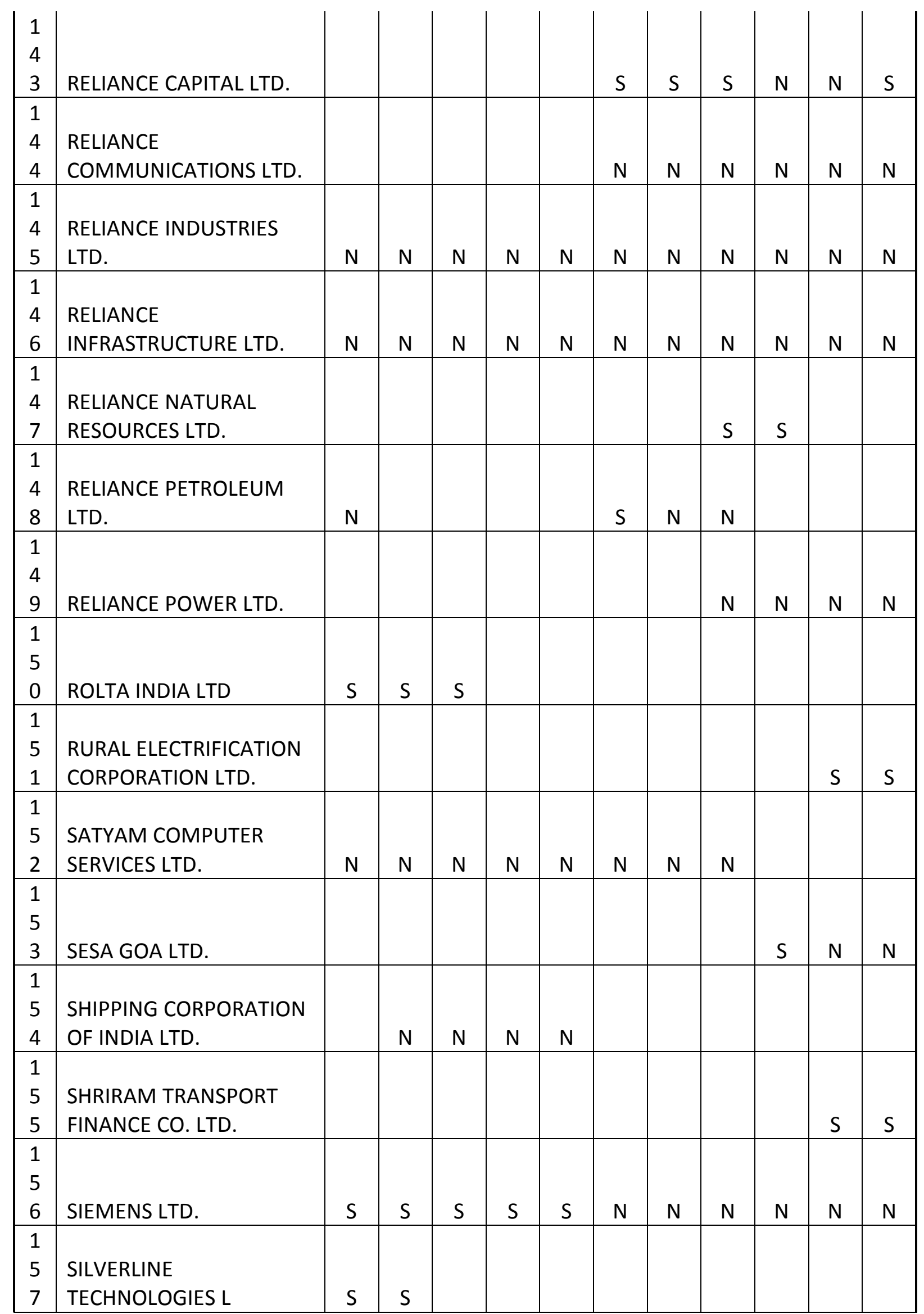




\begin{tabular}{|c|c|c|c|c|c|c|c|c|c|c|c|c|}
\hline 8 & SPIC LTD & $\mathrm{S}$ & & & & & & & & & & \\
\hline 9 & STATE BANK OF INDIA & $\mathrm{N}$ & $\mathrm{N}$ & $\mathrm{N}$ & $\mathrm{N}$ & $\mathrm{N}$ & $\mathrm{N}$ & $\mathrm{N}$ & $\mathrm{N}$ & $\mathrm{N}$ & $\mathrm{N}$ & $\mathrm{N}$ \\
\hline $\begin{array}{l}1 \\
6 \\
0\end{array}$ & $\begin{array}{l}\text { STEEL AUTHORITY OF } \\
\text { INDIA LTD. }\end{array}$ & & & $\mathrm{N}$ & $\mathrm{N}$ & $\mathrm{N}$ & $\mathrm{N}$ & $\mathrm{N}$ & $\mathrm{N}$ & $\mathrm{N}$ & $\mathrm{N}$ & $\mathrm{N}$ \\
\hline $\begin{array}{l}1 \\
6 \\
1\end{array}$ & $\begin{array}{l}\text { STERLITE INDUSTRIES } \\
\text { (INDIA) LTD. }\end{array}$ & & & & & $\mathrm{S}$ & $\mathrm{S}$ & $\mathrm{N}$ & $\mathrm{N}$ & $\mathrm{N}$ & $\mathrm{N}$ & $\mathrm{N}$ \\
\hline $\begin{array}{l}1 \\
6 \\
2\end{array}$ & $\begin{array}{l}\text { SUN PHARMACEUTICAL } \\
\text { INDUSTRIES LTD. }\end{array}$ & $\mathrm{S}$ & $\mathrm{N}$ & $\mathrm{N}$ & $\mathrm{N}$ & $\mathrm{N}$ & $\mathrm{N}$ & $\mathrm{N}$ & $\mathrm{N}$ & $\mathrm{N}$ & $\mathrm{N}$ & $\mathrm{N}$ \\
\hline $\begin{array}{l}1 \\
6 \\
3\end{array}$ & SUZLON ENERGY LTD. & & & & & & $\mathrm{N}$ & $\mathrm{N}$ & $\mathrm{N}$ & $\mathrm{N}$ & $\mathrm{N}$ & \\
\hline $\begin{array}{l}1 \\
6 \\
4\end{array}$ & SYNDICATE BANK & & & & $\mathrm{S}$ & $\mathrm{S}$ & $\mathrm{S}$ & $\mathrm{S}$ & $\mathrm{S}$ & $\mathrm{S}$ & $\mathrm{S}$ & \\
\hline $\begin{array}{l}1 \\
6 \\
5\end{array}$ & TATA CHEMICALS LTD. & $\mathrm{N}$ & $\mathrm{N}$ & $\mathrm{N}$ & $\mathrm{N}$ & $\mathrm{N}$ & & & & & $\mathrm{S}$ & $\mathrm{S}$ \\
\hline $\begin{array}{l}1 \\
6 \\
6\end{array}$ & $\begin{array}{l}\text { TATA COMMUNICATIONS } \\
\text { LTD. }\end{array}$ & & $\mathrm{N}$ & $\mathrm{N}$ & $\mathrm{N}$ & $\mathrm{N}$ & $\mathrm{N}$ & $\mathrm{N}$ & $\mathrm{N}$ & & & \\
\hline $\begin{array}{l}1 \\
6 \\
7\end{array}$ & $\begin{array}{l}\text { TATA CONSULTANCY } \\
\text { SERVICES LTD. }\end{array}$ & & & & & $\mathrm{N}$ & $\mathrm{N}$ & $\mathrm{N}$ & $\mathrm{N}$ & $\mathrm{N}$ & $\mathrm{N}$ & $\mathrm{N}$ \\
\hline $\begin{array}{l}1 \\
6 \\
8\end{array}$ & $\begin{array}{l}\text { TATA GLOBAL } \\
\text { BEVERAGES LTD. }\end{array}$ & $\mathrm{N}$ & $\mathrm{N}$ & $\mathrm{N}$ & $\mathrm{N}$ & $\mathrm{N}$ & & & & & & \\
\hline $\begin{array}{l}1 \\
6 \\
9\end{array}$ & TATA INFOTECH LTD. & $S$ & $\mathrm{~S}$ & & & & & & & & & \\
\hline $\begin{array}{l}1 \\
7 \\
0\end{array}$ & TATA MOTORS LTD. & $\mathrm{N}$ & $\mathrm{N}$ & $\mathrm{N}$ & $\mathrm{N}$ & $\mathrm{N}$ & $\mathrm{N}$ & $\mathrm{N}$ & $\mathrm{N}$ & $\mathrm{N}$ & $\mathrm{N}$ & $\mathrm{N}$ \\
\hline $\begin{array}{l}1 \\
7 \\
1\end{array}$ & TATA POWER CO. LTD. & $\mathrm{N}$ & $\mathrm{N}$ & $\mathrm{N}$ & $\mathrm{N}$ & $\mathrm{N}$ & $\mathrm{N}$ & $\mathrm{N}$ & $\mathrm{N}$ & $\mathrm{N}$ & $\mathrm{N}$ & $\mathrm{N}$ \\
\hline $\begin{array}{l}1 \\
7 \\
2\end{array}$ & TATA STEEL LTD. & $\mathrm{N}$ & $\mathrm{N}$ & $\mathrm{N}$ & $\mathrm{N}$ & $\mathrm{N}$ & $\mathrm{N}$ & $\mathrm{N}$ & $\mathrm{N}$ & $\mathrm{N}$ & $\mathrm{N}$ & $\mathrm{N}$ \\
\hline
\end{tabular}




\begin{tabular}{|c|c|c|c|c|c|c|c|c|c|c|c|c|}
\hline $\begin{array}{l}1 \\
7 \\
3\end{array}$ & $\begin{array}{l}\text { TATA TELESERVICES } \\
\text { (MAHARASHTRA) LTD. }\end{array}$ & & & $\mathrm{S}$ & $\mathrm{S}$ & $\mathrm{S}$ & $\mathrm{S}$ & $\mathrm{S}$ & $\mathrm{S}$ & $\mathrm{S}$ & & \\
\hline $\begin{array}{l}1 \\
7 \\
4\end{array}$ & TECH MAHINDRA LTD. & & & & & & & $\mathrm{S}$ & $\mathrm{S}$ & $\mathrm{S}$ & $\mathrm{S}$ & $\mathrm{S}$ \\
\hline $\begin{array}{l}7 \\
5\end{array}$ & $\begin{array}{l}\text { THOMAS COOK (INDIA) } \\
\text { LTD }\end{array}$ & $\mathrm{S}$ & $\mathrm{S}$ & $\mathrm{S}$ & & & & & & & & \\
\hline $\begin{array}{l}1 \\
7\end{array}$ & TITAN INDUSTRIES LTD. & $\mathrm{S}$ & $\mathrm{S}$ & $\mathrm{S}$ & & & & & & & & $\mathrm{S}$ \\
\hline $\begin{array}{l}1 \\
7 \\
7\end{array}$ & TORRENT POWER LTD. & & & & & & & & & & S & $\mathrm{S}$ \\
\hline $\begin{array}{l}1 \\
7 \\
8\end{array}$ & $\begin{array}{l}\text { TVS MOTOR COMPANY } \\
\text { LTD. }\end{array}$ & & & $\mathrm{S}$ & $\mathrm{S}$ & $\mathrm{S}$ & $\mathrm{S}$ & $\mathrm{S}$ & & & & \\
\hline $\begin{array}{l}1 \\
7 \\
9\end{array}$ & ULTRATECH CEMENT LTD. & & & & & & & $\mathrm{S}$ & $\mathrm{S}$ & $\mathrm{S}$ & $\mathrm{S}$ & $\mathrm{S}$ \\
\hline $\begin{array}{l}1 \\
8 \\
0\end{array}$ & UNION BANK OF INDIA & & & $\mathrm{S}$ & $\mathrm{S}$ & $\mathrm{S}$ & $\mathrm{S}$ & $\mathrm{S}$ & $\mathrm{S}$ & $\mathrm{S}$ & $\mathrm{S}$ & $\mathrm{S}$ \\
\hline $\begin{array}{l}1 \\
8 \\
1\end{array}$ & UNITECH LTD. & & & & & & & $\mathrm{N}$ & $\mathrm{N}$ & $\mathrm{N}$ & & \\
\hline $\begin{array}{l}1 \\
8 \\
2\end{array}$ & $\begin{array}{l}\text { UNITED PHOSPHORUS } \\
\text { LTD. }\end{array}$ & S & & & & & & & & S & $\mathrm{S}$ & $\mathrm{S}$ \\
\hline $\begin{array}{l}1 \\
8 \\
3\end{array}$ & UNITED SPIRITS LTD. & & & & & & & $\mathrm{S}$ & $\mathrm{S}$ & $\mathrm{S}$ & $\mathrm{S}$ & $\mathrm{S}$ \\
\hline $\begin{array}{l}1 \\
8 \\
4\end{array}$ & VIJAYA BANK & & & & $\mathrm{S}$ & $\mathrm{S}$ & $\mathrm{S}$ & $\mathrm{S}$ & $\mathrm{S}$ & & & \\
\hline $\begin{array}{l}1 \\
8 \\
5\end{array}$ & WARTSILA INDIA LTD & $\mathrm{S}$ & & & & & & & & & & \\
\hline $\begin{array}{l}1 \\
8 \\
6\end{array}$ & WIPRO LTD. & & $\mathrm{N}$ & $\mathrm{N}$ & $\mathrm{N}$ & $\mathrm{N}$ & $\mathrm{N}$ & $\mathrm{N}$ & $\mathrm{N}$ & $\mathrm{N}$ & $\mathrm{N}$ & $\mathrm{N}$ \\
\hline $\begin{array}{l}1 \\
8 \\
7\end{array}$ & WOCKHARDT LTD. & & $\mathrm{S}$ & S & S & $\mathrm{S}$ & S & S & S & & & \\
\hline
\end{tabular}




\begin{tabular}{|c|c|c|c|c|c|c|c|c|c|c|c|c|}
\hline $\begin{array}{l}1 \\
8 \\
8\end{array}$ & YES BANK LTD. & & & & & & & & & & $\mathrm{S}$ & $\mathrm{S}$ \\
\hline 1 & & & & & & & & & & & & \\
\hline $\begin{array}{l}8 \\
9\end{array}$ & $\begin{array}{l}\text { ZEE ENTERTAINMENT } \\
\text { ENTERPRISES LTD. }\end{array}$ & $\mathrm{N}$ & $\mathrm{N}$ & $\mathrm{N}$ & $\mathrm{N}$ & $\mathrm{N}$ & $\mathrm{N}$ & $\mathrm{N}$ & $\mathrm{N}$ & $\mathrm{S}$ & & $\mathrm{S}$ \\
\hline
\end{tabular}

Exhibit-12, List of Companies in Set B as per Year of Listing

(L= Listed, DL= Delisted)

\begin{tabular}{|c|c|c|c|c|c|c|c|c|c|c|c|c|}
\hline S.No & Name of Company & 2001 & 2002 & 2003 & 2004 & 2005 & 2006 & 2007 & 2008 & 2009 & 2010 & 2011 \\
\hline 1 & ACC LTD. & $\mathrm{L}$ & & & & & & & & & & \\
\hline 2 & ADANI ENTERPRISES LTD. & $\mathrm{L}$ & & & & & & & & & & \\
\hline 3 & ADANI PORTS AND SPECIAL ECONOMIC ZONE LTD. & & & & & & & $\mathrm{L}$ & & & & \\
\hline 4 & ADITYA BIRLA NUVO LTD. & L & & & & & & & & & & \\
\hline 5 & AMBUJA CEMENTS LTD. & L & & & & & & & & & & \\
\hline 6 & ANDHRA BANK & $\mathrm{L}$ & & & & & & & & & & \\
\hline 7 & ASHOK LEYLAND LTD. & $\mathrm{L}$ & & & & & & & & & & \\
\hline 8 & ASIAN PAINTS LTD. & $\mathrm{L}$ & & & & & & & & & & \\
\hline 9 & AXIS BANK LTD. & $\mathrm{L}$ & & & & & & & & & & \\
\hline 10 & BAJAJ AUTO LTD. & & & & & & & & $\mathrm{L}$ & & & \\
\hline 11 & BANK OF BARODA & $\mathrm{L}$ & & & & & & & & & & \\
\hline 12 & BANK OF INDIA & L & & & & & & & & & & \\
\hline 13 & BHARAT ELECTRONICS LTD. & $\mathrm{L}$ & & & & & & & & & & \\
\hline 14 & BHARAT FORGE LTD. & $\mathrm{L}$ & & & & & & & & & & \\
\hline 15 & BHARAT HEAVY ELECTRICALS LTD. & $\mathrm{L}$ & & & & & & & & & & \\
\hline 16 & BHARAT PETROLEUM CORPORATION LTD. & $\mathrm{L}$ & & & & & & & & & & \\
\hline 17 & BHARTI AIRTEL LTD. & & $\mathrm{L}$ & & & & & & & & & \\
\hline 18 & BIOCON LTD. & & & & $\mathrm{L}$ & & & & & & & \\
\hline 19 & BOSCH LTD. & $\mathrm{L}$ & & & & & & & & & & \\
\hline 20 & CAIRN INDIA LTD. & & & & & & $\mathrm{L}$ & & & & & \\
\hline 21 & CANARA BANK & & L & & & & & & & & & \\
\hline 22 & CIPLA LTD. & $\mathrm{L}$ & & & & & & & & & & \\
\hline 23 & COAL INDIA LTD. & & & & & & & & & & $\mathrm{L}$ & \\
\hline 24 & COLGATE PALMOLIVE (INDIA) LTD. & L & & & & & & & & & & \\
\hline
\end{tabular}




\begin{tabular}{|c|c|c|c|c|c|c|c|c|c|c|c|c|}
\hline S.No & Name of Company & 2001 & 2002 & 2003 & 2004 & 2005 & 2006 & 2007 & 2008 & 2009 & 2010 & 2011 \\
\hline 25 & CONTAINER CORPORATION OF INDIA LTD. & $\mathrm{L}$ & & & & & & & & & & \\
\hline 26 & CROMPTON GREAVES LTD. & L & & & & & & & & & & \\
\hline 27 & CUMMINS INDIA LTD. & $\mathrm{L}$ & & & & & & & & & & \\
\hline 28 & DABUR INDIA LTD. & $\mathrm{L}$ & & & & & & & & & & \\
\hline 29 & DLF LTD. & & & & & & & $\mathrm{L}$ & & & & \\
\hline 30 & DR. REDDY'S LABORATORIES LTD. & $\mathrm{L}$ & & & & & & & & & & \\
\hline 31 & EXIDE INDUSTRIES LTD. & $\mathrm{L}$ & & & & & & & & & & \\
\hline 32 & FEDERAL BANK LTD. & & $\mathrm{L}$ & & & & & & & & & \\
\hline 33 & GAIL (INDIA) LTD. & $\mathrm{L}$ & & & & & & & & & & \\
\hline 34 & GLAXOSMITHKLINE PHARMACEUTICALS LTD. & L & & & & & & & & & & \\
\hline 35 & GLENMARK PHARMACEUTICALS LTD. & $\mathrm{L}$ & & & & & & & & & & \\
\hline 36 & GMR INFRASTRUCTURE LTD. & & & & & & $\mathrm{L}$ & & & & & \\
\hline 37 & GRASIM INDUSTRIES LTD. & L & & & & & & & & & & \\
\hline 38 & HCL TECHNOLOGIES LTD. & $\mathrm{L}$ & & & & & & & & & & \\
\hline 39 & HDFC BANK LTD. & $\mathrm{L}$ & & & & & & & & & & \\
\hline 40 & HERO MOTOCORP LTD. & $\mathrm{L}$ & & & & & & & & & & \\
\hline 41 & HINDALCO INDUSTRIES LTD. & $\mathrm{L}$ & & & & & & & & & & \\
\hline 42 & HINDUSTAN PETROLEUM CORPORATION LTD. & $\mathrm{L}$ & & & & & & & & & & \\
\hline 43 & HINDUSTAN UNILEVER LTD. & L & & & & & & & & & & \\
\hline 44 & HOUSING DEVELOPMENT AND INFRASTRUCTURE LTD. & & & & & & & $\mathrm{L}$ & & & & \\
\hline 45 & HOUSING DEVELOPMENT FINANCE CORPORATION LTD. & L & & & & & & & & & & \\
\hline 46 & IT C LTD. & $\mathrm{L}$ & & & & & & & & & & \\
\hline 47 & ICICI BANK LTD. & $\mathrm{L}$ & & & & & & & & & & \\
\hline 48 & IDBI BANK LTD. & $\mathrm{L}$ & & & & & & & & & & \\
\hline 49 & IDEA CELLULAR LTD. & & & & & & & L & & & & \\
\hline 50 & IFCI LTD. & L & & & & & & & & & & \\
\hline 51 & INDIAN HOTELS CO. LTD. & $\mathrm{L}$ & & & & & & & & & & \\
\hline 52 & INDIAN OVERSEAS BANK & L & & & & & & & & & & \\
\hline 53 & INDUSIND BANK LTD. & L & & & & & & & & & & \\
\hline 54 & INFOSYS LTD. & $\mathrm{L}$ & & & & & & & & & & \\
\hline 55 & INFRASTRUCTURE DEVELOPMENT FINANCE CO. LTD. & & & & & $\mathrm{L}$ & & & & & & \\
\hline 56 & JAIPRAKASH ASSOCIATES LTD. & & & & $\mathrm{L}$ & & & & & & & \\
\hline 57 & JINDAL STEEL \& POWER LTD. & $\mathrm{L}$ & & & & & & & & & & \\
\hline 58 & JSW STEEL LTD. & $\mathrm{L}$ & & & & & & & & & & \\
\hline 59 & KOTAK MAHINDRA BANK LTD. & L & & & & & & & & & & \\
\hline 60 & LARSEN \& TOUBRO LTD. & $\mathrm{L}$ & & & & & & & & & & \\
\hline 61 & LIC HOUSING FINANCE LTD. & $\mathrm{L}$ & & & & & & & & & & \\
\hline 62 & LUPIN LTD. & L & & & & & & & & & & \\
\hline 63 & MAHINDRA \& MAHINDRA LTD. & $\mathrm{L}$ & & & & & & & & & & \\
\hline 64 & MARUTI SUZUKI INDIA LTD. & & & $\mathrm{L}$ & & & & & & & & \\
\hline 65 & MPHASIS LTD. & L & & $\mathrm{DL}$ & L & & & & & & & \\
\hline
\end{tabular}




\begin{tabular}{|c|c|c|c|c|c|c|c|c|c|c|c|c|}
\hline S.No & Name of Company & 2001 & 2002 & 2003 & 2004 & 2005 & 2006 & 2007 & 2008 & 2009 & 2010 & 2011 \\
\hline 66 & NTPC LTD. & & & & $\mathrm{L}$ & & & & & & & \\
\hline 67 & OIL \& NATURAL GAS CORPORATION LTD. & $\mathrm{L}$ & & & & & & & & & & \\
\hline 68 & ORACLE FINANCIAL SERVICES SOFTWARE LTD. & & $\mathrm{L}$ & & & & & & & & & \\
\hline 69 & POWER FINANCE CORPORATION LTD. & & & & & & & $\mathrm{L}$ & & & & \\
\hline 70 & POWER GRID CORPORATION OF INDIA LTD. & & & & & & & $\mathrm{L}$ & & & & \\
\hline 71 & PUNJAB NATIONAL BANK & & $\mathrm{L}$ & & & & & & & & & \\
\hline 72 & RANBAXY LABORATORIES LTD. & $\mathrm{L}$ & & & & & & & & & & \\
\hline 73 & RELIANCE CAPITAL LTD. & $\mathrm{L}$ & & & & & & & & & & \\
\hline 74 & RELIANCE COMMUNICATIONS LTD. & & & & & & $\mathrm{L}$ & & & & & \\
\hline 75 & RELIANCE INDUSTRIES LTD. & $\mathrm{L}$ & & & & & & & & & & \\
\hline 76 & RELIANCE INFRASTRUCTURE LTD. & $\mathrm{L}$ & & & & & & & & & & \\
\hline 77 & RELIANCE POWER LTD. & & & & & & & & $\mathrm{L}$ & & & \\
\hline 78 & RURAL ELECTRIFICATION CORPORATION LTD. & & & & & & & & $\mathrm{L}$ & & & \\
\hline 79 & SESA GOA LTD. & $\mathrm{L}$ & & & & & & & & & & \\
\hline 80 & SHRIRAM TRANSPORT FINANCE CO. LTD. & $\mathrm{L}$ & & & & & & & & & & \\
\hline 81 & SIEMENS LTD. & $\mathrm{L}$ & & & & & & & & & & \\
\hline 82 & STATE BANK OF INDIA & $\mathrm{L}$ & & & & & & & & & & \\
\hline 83 & STEEL AUTHORITY OF INDIA LTD. & $\mathrm{L}$ & & & & & & & & & & \\
\hline 84 & STERLITE INDUSTRIES (INDIA) LTD. & $\mathrm{L}$ & & & & & & & & & & \\
\hline 85 & SUN PHARMACEUTICAL INDUSTRIES LTD. & $\mathrm{L}$ & & & & & & & & & & \\
\hline 86 & TATA CHEMICALS LTD. & $\mathrm{L}$ & & & & & & & & & & \\
\hline 87 & TATA CONSULTANCY SERVICES LTD. & & & & $\mathrm{L}$ & & & & & & & \\
\hline 88 & TATA MOTORS LTD. & $\mathrm{L}$ & & & & & & & & & & \\
\hline 89 & TATA POWER CO. LTD. & $\mathrm{L}$ & & & & & & & & & & \\
\hline 90 & TATA STEEL LTD. & $\mathrm{L}$ & & & & & & & & & & \\
\hline 91 & TECH MAHINDRA LTD. & & & & & & $\mathrm{L}$ & & & & & \\
\hline 92 & TITAN INDUSTRIES LTD. & $\mathrm{L}$ & & & & & & & & & & \\
\hline 93 & TORRENT POWER LTD. & & & & & & $\mathrm{L}$ & & & & & \\
\hline 94 & ULTRATECH CEMENT LTD. & & & & $\mathrm{L}$ & & & & & & & \\
\hline 95 & UNION BANK OF INDIA & & $\mathrm{L}$ & & & & & & & & & \\
\hline 96 & UNITED PHOSPHORUS LTD. & $\mathrm{L}$ & & & & & & & & & & \\
\hline 97 & UNITED SPIRITS LTD. & $\mathrm{L}$ & & & & & & & & & & \\
\hline 98 & WIPRO LTD. & $\mathrm{L}$ & & & & & & & & & & \\
\hline 99 & YES BANK LTD. & & & & & $\mathrm{L}$ & & & & & & \\
\hline 100 & ZEE ENTERTAINMENT ENTERPRISES LTD. & $\mathrm{L}$ & & & & & & & & & & \\
\hline
\end{tabular}

